\title{
Highly-skilled migration and new destination countries : how government policies shape destination choices
}

Citation for published version (APA):

Hercog, M. (2014). Highly-skilled migration and new destination countries : how government policies shape destination choices. [Doctoral Thesis, Maastricht University]. Boekenplan. https://doi.org/10.26481/dis.20140625mh

Document status and date:

Published: 01/01/2014

DOI:

10.26481/dis.20140625mh

Document Version:

Publisher's PDF, also known as Version of record

\section{Please check the document version of this publication:}

- A submitted manuscript is the version of the article upon submission and before peer-review. There can be important differences between the submitted version and the official published version of record.

People interested in the research are advised to contact the author for the final version of the publication, or visit the DOI to the publisher's website.

- The final author version and the galley proof are versions of the publication after peer review.

- The final published version features the final layout of the paper including the volume, issue and page numbers.

Link to publication

\footnotetext{
General rights rights.

- You may freely distribute the URL identifying the publication in the public portal. please follow below link for the End User Agreement:

www.umlib.nl/taverne-license

Take down policy

If you believe that this document breaches copyright please contact us at:

repository@maastrichtuniversity.nl

providing details and we will investigate your claim.
}

Copyright and moral rights for the publications made accessible in the public portal are retained by the authors and/or other copyright owners and it is a condition of accessing publications that users recognise and abide by the legal requirements associated with these

- Users may download and print one copy of any publication from the public portal for the purpose of private study or research.

- You may not further distribute the material or use it for any profit-making activity or commercial gain

If the publication is distributed under the terms of Article $25 \mathrm{fa}$ of the Dutch Copyright Act, indicated by the "Taverne" license above, 


\section{HIGHLY-SKILLED MIGRATION AND NEW DESTINATION COUNTRIES}

How government policies shape destination choices 
(C) 2014 Metka Hercog

All rights reserved. No part of this publication may be reproduced, stored in a retrieval sys- tem, or transmitted in any form, or by any means, electronic, mechanical, photocopying, recording or otherwise, without the prior permission in writing, from the author.

ISBN 978-90-8666-333-0

Cover illustration by Neja Kotnik

Publisher: Boekenplan, Maastricht 


\title{
HIGHLY-SKILLED MIGRATION AND NEW DESTINATION COUNTRIES:
}

How government policies shape destination choices

\author{
DISSERTATION
}

to obtain the degree of Doctor at

Maastricht University,

on the authority of the Rector Magnificus, Prof.dr. L.L.G. Soete in accordance with the decision of the Board of Deans,

to be defended in public

on Wednesday 25 June 2014, at 14.00 hours

by

Metka Hercog 
Promotor:

Prof. dr. Hildegard Schneider

Supervisor:

Dr. Mindel van de Laar

Assessment committee:

Prof. dr. Joan Muysken, chairman

Prof. dr. Ronald Skeldon, University of Sussex

Prof. dr. Khalid Koser, Geneva Centre for Security Policy

Prof. dr. Binod Khadria, Jawaharlal Nehru University

Dr. Gabriela Tejada, École Polytechnique Fédérale de Lausanne 


\section{Acknowledgments}

This dissertation would not have been possible without the invaluable help of so many people in so many ways, be it as supervisors, co-authors, colleagues, friends or family. It is also the product of chance encounters with people who have changed the course of this dissertation and with it, my life in general. I feel privileged to have so many wonderful people around me. A few people within this auspicious crowd deserve special gratitude. First and foremost, I am deeply grateful to my supervisors for their supportive and encouraging mentorship. Prof. Hildegard Schneider provided me with solid advice and inevitably transmitted to me some of her contagious enthusiasm for migration policies. Dr. Mindel van de Laar, I can say without any reservation that I would have never reached this point without your unrelenting encouragements and motivation. I remain forever grateful for all the time and energy you invested in me. I thank Prof. Chris de Neubourg who gave me the opportunity to start the $\mathrm{PhD}$ and whose advice was instrumental in giving shape to my research ideas and writing.

I am thankful to the members of the reading committee-Prof. Binod Khadria, Prof. Khalid Koser, Prof. Joan Muysken, Prof. Ronald Skeldon and Dr. Gabriela Tejadafor their insightful comments which helped me to enrich the final version of the dissertation.

Support for the fieldwork in India was provided by the Zakir Husain Centre for Educational Studies, School of Social Sciences at Jawaharlal Nehru University in New Delhi. I am indebted to Prof. Binod Khadria for providing valuable comments on the reseach tools and for together with his team facilitate my data-collection. I also want to thank all the students and professionals who generously took time to participate in the survey and share their stories in the interviews.

I would like to thank the Institute for the Study of International Migration (ISIM) at Georgetown University for offering me a visiting fellowship. I benefited from discussions with Dr. Lindsay Lowell, Prof. Susan Martin. Dr. Mary Breeding and Dr. Hamutal Bernstein.

A special word of gratitude goes to Dr. Anja Wiesbrock for our constructive discussions and for her patience of writing together. The help of Ezequiel Tacsir was instrumental in grappling with the hard work of quantitative analysis. I am indebted also to Dr. Robert Bauchmüller and Dr. Semih Akcomak for guiding me through the data analysis parts. Manoj Viswanathan, thank you for proofreading parts of my thesis and placing indefinite and definite articles where they belong. I am solely responsible for any remaining errors.

Within the School of Governance, I was lucky to share the experience with wonderful friends and colleagues. In particular, I thank my classmates Maha, Marina, Nicola, Robert, Victor, Judit, Henry and Jinjing for all the conversations and for providing a sense of community. I learned a lot from all of you. Marina taught 
me how it is not worth worrying over small things, Maha taught me the opposite. Robert remains a source of inspiration for his dedication, hard work and loyalty. Melissa, thank you for being my first encounter with the School and for all the great days we shared as colleagues, friends and flatmates. I thank Cheng, Denisa, Sepideh, Florian, Mahmut, Eze, Carlos, Sonila, Renée ... for making these years more fun and memorable than one could wish for. Each of you deserves a separate page of fond memories I have of you.

Thank you Maastricht for being such a glorious city giving me all the charmed days and for making me write dairies like this one:

Morning: A woman runs after me, waving with a belt that I lost while cycling to school in the morning. She made my day.

Lunch: Chatting with Alexandra over Zigeunerschnitzel at Preuverij.

Afternoon: Getting hit in the back by a ball while squashing with Maha. I win, nevertheless. Evening: Helping out at the bar in the best cinema in the world. Learning how to pour beer from a tap. Chatting with random customer. I talk to people who think Ingrid Bergman is the most attractive actress ever. And who haven't heard of Scarlett Johansson. I drink Chardonnay.

I come home and a Porsche and an MG are parked in our front yard. I brush my teeth.

This thesis would not have reached the end without people who have been there for me when self-doubt and frustration creeps in. Ana, I owe you a whole list of thanks but let me stay with thanking you for always being there for me. Cheng, the friendship I have with you means the world to me. Katarina, you remain one of the hallmarks of my stay in Maastricht. Jure, even though you were not in Maastricht, you shared every frustration with me, from the beginning to the end. I thank you for that.

Substantive parts of writing and data collection were done in different parts of the world. Neha, thank you for sharing your home and family with me and for introducing me to New Delhi. I want to thank Amrit, Saoirse and Daniela for sharing many fun bits of living in India. Justin, Adriana and Manoj thank you for making my stay in Washington, DC an unforgettable experience. Urška, thank you for bringing joy with you wherever you visited me. My list of thank yous would not be complete without naming a few persons who encouraged me in the final and crucial stages of writing from Switzerland. Lucia, Alberto, Rafael, Nathaly and Natalie, thank you for being there.

This brings me to my dearest ones. Ivan, whatever I can think of saying cannot express how much I appreciate your endless love and support. I will just say thank you for being you. Finally, I thank my family for encouraging me to follow my own path and for all their help at every step I take. Hvala vam. 


\section{Contents}

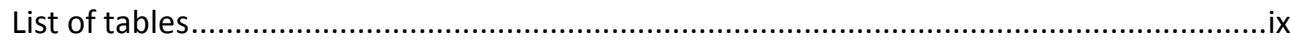

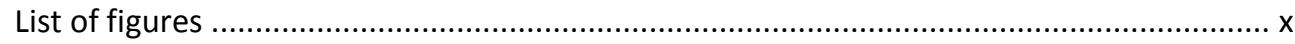

\section{Part I}

Introduction.

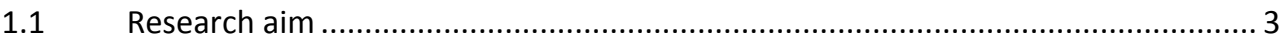

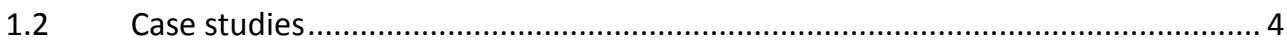

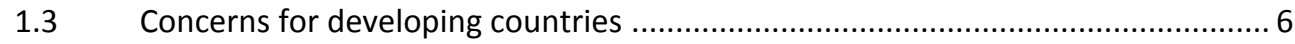

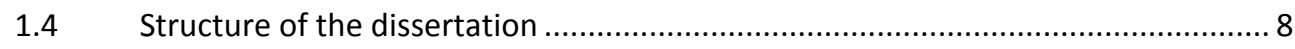

$2 \quad$ Policy Instruments: What Theory Teaches Us?

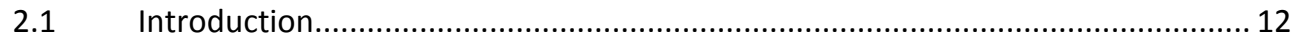

2.2 Reasons for encouragement of skilled migration ................................................ 13

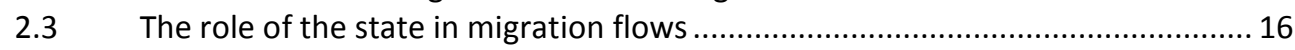

2.4 Overview of theories on determinants of migration ....................................... 20

2.4.1 The neoclassical theory of migration .................................................... 21

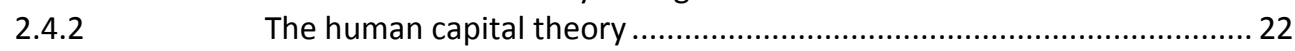

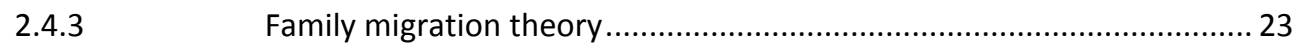

2.4.4 The 'New Economics of Labour Migration' ......................................... 24

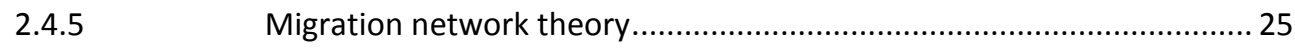

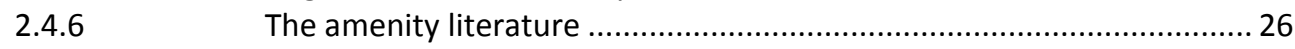

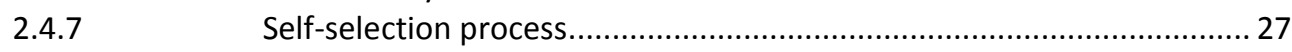

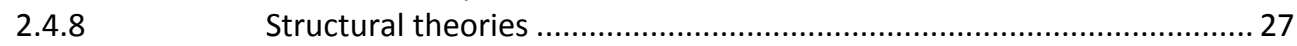

2.5 Combining the implications of the theories for the role of the state .................... 28

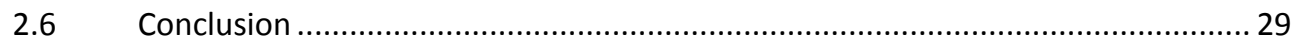

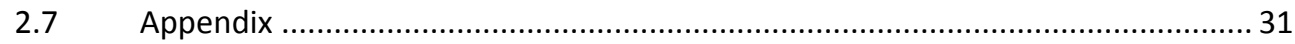

3 Highly-Skilled Migration to the EU and the US: The Legal Framework

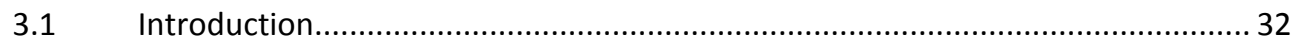

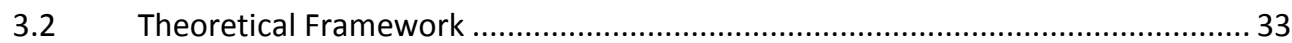

3.3 Comparative Criteria for Immigration Policies ................................................. 36

3.4 Comparing Highly-Skilled Migration Policies in the United States and the EU 39

3.4.1 The Definition of the 'Highly Skilled' and Eligibility Requirements ......... 40

3.4.2 Special Provisions for Young Migrants and Former Students ................. 44

3.4.3 Validity of the Permit and Access to Permanent Residence .................... 47

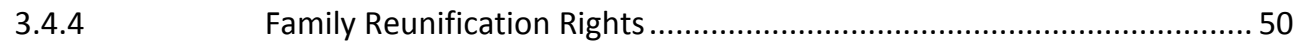

3.4.5 Employment Rights and Social Security Provision .................................. 52

3.5 European vs. US Policies and the Added Value of the Blue Card Directive........... 54

3.5.1 European and US Policies Compared ................................................... 54

3.5.2 The Blue Card Directive: What Does It Add? .......................................... 56

3.6 Conclusions: Assessing the Attractiveness of National Rules on Highly-Skilled Migration 59

4 Trends in Migration Policy in The Netherlands

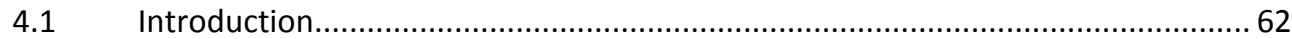

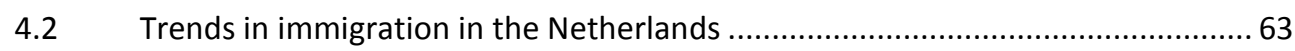

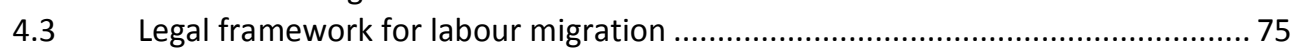

4.4 Immigration of Indians to the Netherlands ................................................... 81

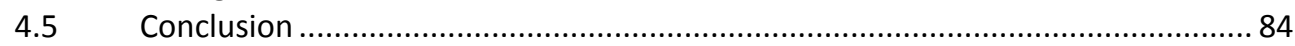




\section{Part II}

5 The Case of India: Methodology and Descriptive Statistics

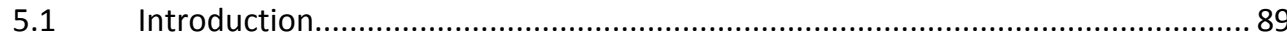

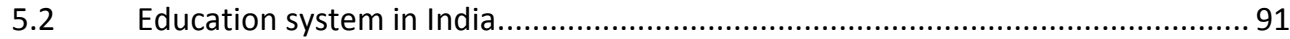

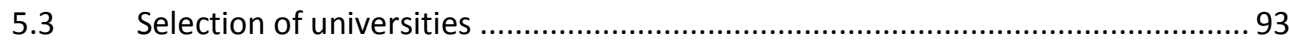

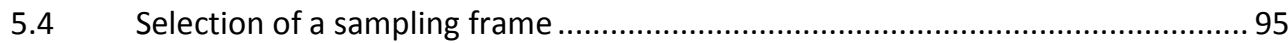

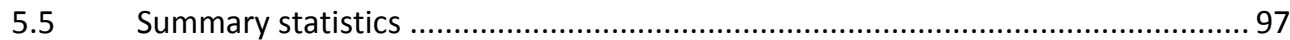

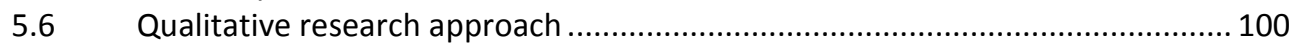

5.7 Research questions and hypotheses .......................................................... 101

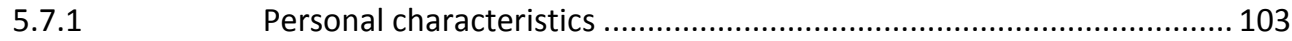

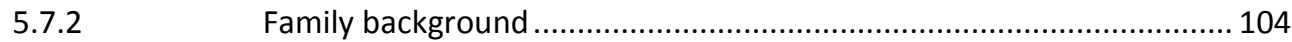

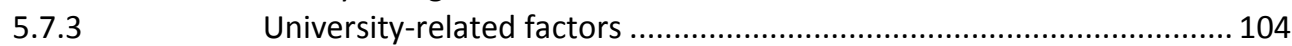

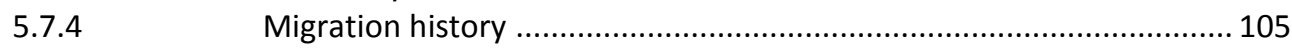

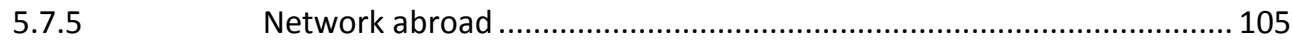

5.7.6 Individual perception of importance of factors .................................. 106

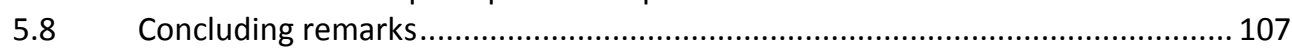

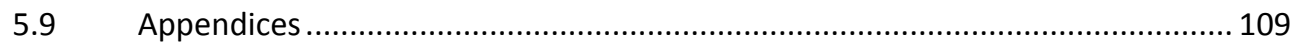

6 Determinants of International Mobility Decision: The Case-Study of India

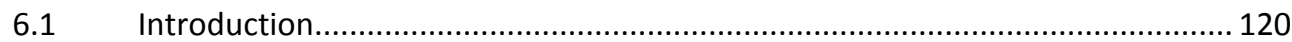

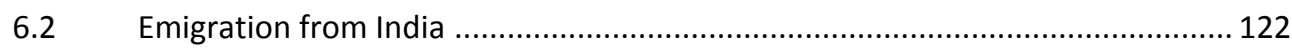

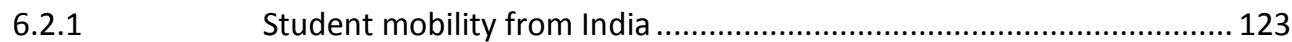

6.3 Descriptive analysis: Planned move abroad versus stay in India ........................ 124

6.3.1 Characteristic differences of movers and non-movers ......................... 124

6.3.2 Evaluation of the factors influencing migration intentions ................. 130

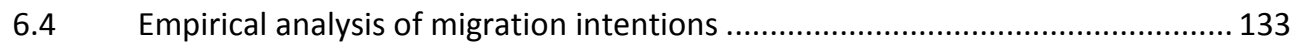

6.4.1 Logistic Regression Model Specifications.......................................... 133

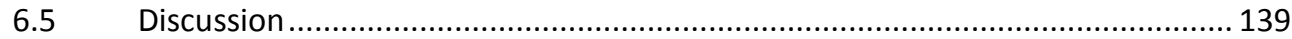

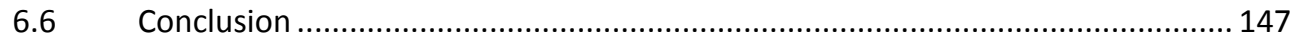

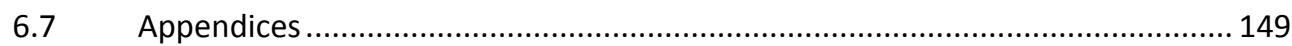

7 What's the Best Place for Me? Migration Location-choice for S\&E Students in India

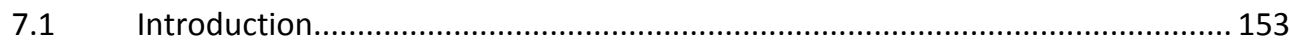

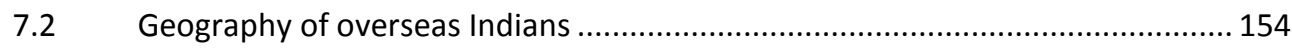

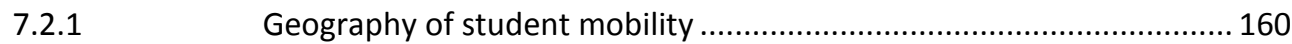

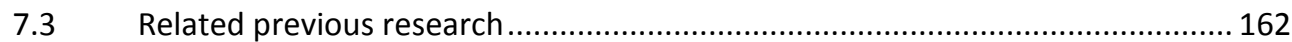

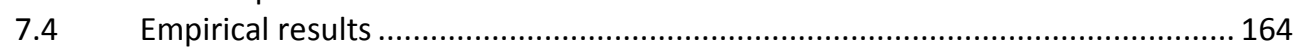

7.4.1 Comparison of respondents by preferred destination ......................... 166

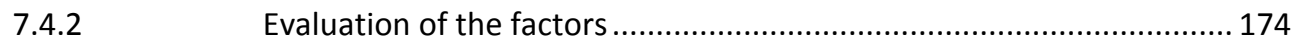

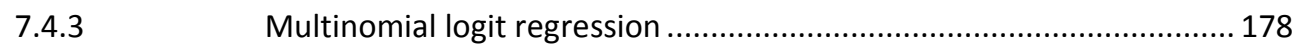

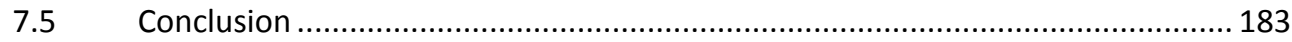

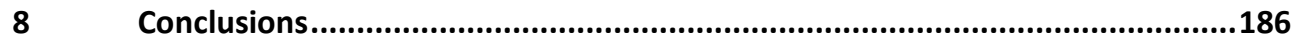

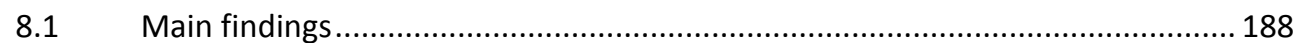

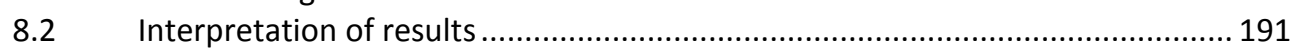

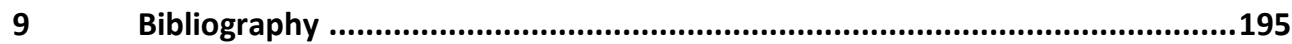

Nederlandse Samenvatting ..............................................................................214

Addendum on valorization to the dissertation .......................................................219

Short biography..............................................................................................................224

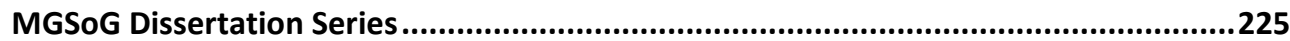




\section{List of Tables}

Table 2.1: A classification of highly skilled mobility, types of influencing factors and

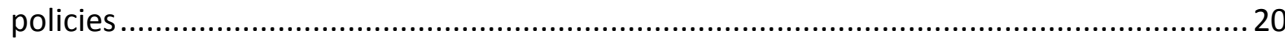

Table 2.2: Overview of theories and implication for the role of the state ........................... 31

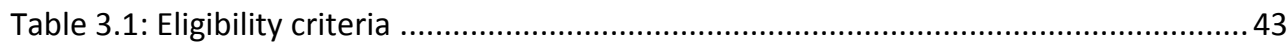

Table 3.2: Policies for young migrants and former students............................................. 47

Table 3.3: Permit validity and access to permanent residence ......................................49

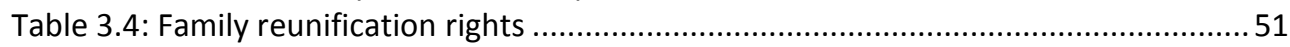

Table 3.5: Employment rights and social security provisions .......................................... 54

Table 4.1: Immigration flows by major countries of origin from 2004 to 2012 ................. 74

Table 4.2: Scheme of the point system for self-employment ......................................... 77

Table 4.3: Number of granted residence permits for knowledge migration by nationality,

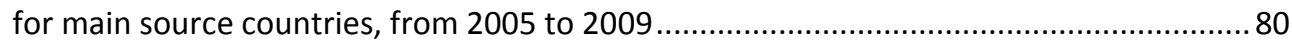

Table 4.4: Immigration flows of people born in India from 2000 and 2011 by migration motive; total number and percentage of male ............................................................... 83

Table 5.1: Type of higher education institutions in India in the academic year 2009/201095

Table 5.2: Methods of collecting surveys at different universities.................................. 96

Table 5.3: Basic characteristics of the surveyed population ............................................. 98

Table 5.4: Questionnaire development on the basis of theory .......................................118

Table 5.5: Theories as a basis for selection of factors of importance for location choice. 119

Table 6.1: Comparison of the S\&E students by main characteristics (in \%) ...................... 126

Table 6.2: What determines plans to move abroad? (Marginal effects after logit

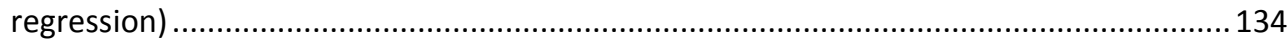

Table 6.3: What determines plans to move abroad? (Results of logit regression)...........150 Table 7.1: Distribution of Indian-born migrants in major OECD destination countries by educational level................................................................................................... 156

Table 7.2: Immigration flows to the selected EU member states from India as country of previous residence, from 1998 to 2009 (absolute numbers) ........................................ 159 Table 7.3: Comparison of the S\&E students by main characteristics according to preferred country (in percentages) ............................................................................................. 168

Table 7.4: Distribution of responses by community across countries and regions ........... 171

Table 7.5: Destination preference and reason for going abroad (in percentages)............174

Table 7.6: Comparison of mean values for factors by country and region alternatives.... 176 Table 7.7: Comparison of mean values for factors relevant for immigration policy by

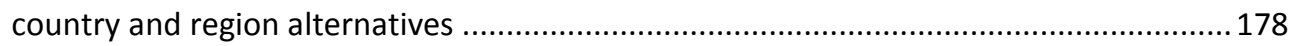

Table 7.8: Country choice coefficient estimation results ............................................ 182 


\section{List of Figures}

Figure 2.1: Patterns of skill supply and demand, Northern and Western Europe, $1990 \ldots . .15$

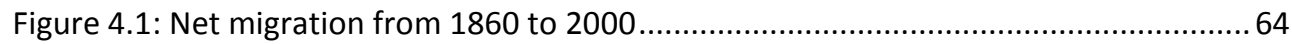

Figure 4.2: Total immigration and emigration, 1995-2011 (in absolute numbers) ............64

Figure 4.3: Immigration of non-Dutch nationals by year of arrival and migration motive from 1995 to 2011 (in absolute numbers) ................................................................... 73

Figure 4.4: Immigration and emigration of migrants born in India, 1995-2012 ................. 82

Figure 6.1: Major countries of origin for internationally mobile students for all reporting

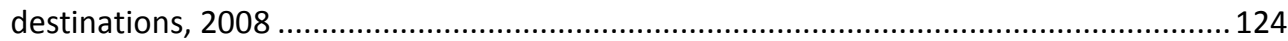

Figure 6.2: How important do you consider the presence of the following characteristics/facilities in a country where you want to live?

Figure 7.1: Immigration flows of Indian-born immigrants (aged 15 and older) in the main OECD destination countries, from 1998 to 2009.

Figure 7.2: Indian-born immigrants in major destination countries by educational levels

Figure 7.3: Number of people obtaining legal permanent resident status in the United States from India as country of last residence, from 1960 to 2009

Figure 7.4: Indian students studying abroad in tertiary education in a given country of residence as a percentage of all Indian citizens studying abroad (2008) in all reporting countries

Figure 7.5: Indian students enrolled abroad in a given country of destination, years 2000, 2004, 2008 and 2011

Figure 7.6: What destinations would you consider if you move abroad? 165

Figure 7.7: What would be your top destination country in case you want to move in the following 5 years?. 166 


\section{Part I}




\section{Introduction ${ }^{1}$}

New Delhi, 2009 - When the Swedish Minister for Migration and Asylum Policy presented immigration reforms in New Delhi in November 2008 he said he is not afraid that Sweden will be inundated by Indians because of the new liberal policy. On the contrary, he is afraid that despite the new policy there will not be many people coming. (G. Gurucharan, Joint Secretary, Ministry of Overseas Indian Affairs, personal communication, February 23, 2009)

Recent trends of international migration signify increased movements of highlyskilled workers to countries other than their own. While on the one hand most developed countries try to curtail immigration of low-skilled labour force, on the other hand some forms of international migration such as by highly-skilled workers are often encouraged and facilitated. The geographical focus of this dissertation on European countries as a destination area is inspired by their status as a relatively new entrant on the market for knowledge migrants competing with the "traditional immigration countries" like Australia, New Zealand, Canada and the United States. The new initiatives represent a major paradigm shift for most European countries, which have for long proclaimed themselves as non-immigration countries (Meyer, Kaplan, \& Charum, 2001). The growing concern with national competitiveness and ageing societies has led many of them to redesign their policies into targeted migration programmes aiming to select specific types of migrants. At the same time, since the start of the European financial crisis 2007, some countries, with a notable example of the United Kingdom, have reversed the earlier trend of liberalizing immigration, while there are other countries remaining on the path of becoming progressively more favourable towards the admission of foreign highlyskilled workers. This trend is expected to persist as a salient feature of immigration policies given that the problems of international competitiveness and demographic ageing remain for the long-term future. The change in migration patterns has led to increased attention of policymakers as well as researchers and whereas selective migration policies are often mentioned as a reason for increasingly skilled migration, there has still not been much empirical research in this field yet (OECD, 2001; Shachar, 2006). The literature either takes it for granted that regulations on entries have a distinct effect on immigration flows, or collects somewhat quick evidence to this effect. Nonetheless, fears of the Swedish Minister for Migration and Asylum Policy Tobias Billström, depicted in the above quote, call to attention a

\footnotetext{
${ }^{1}$ Some ideas in this chapter were also reflected in an earlier piece of writing: Hercog, M. (2008). The Role of the State in Attracting Highly-Skilled Migrants: The Case of the Netherlands. European Institute of Public Administration, EIPASCOPE, No. 3, 2008.
} 
non-straightforward relationship between immigration policies and determinants for migration. The quote usefully represents the main issue tackled by this dissertation: how effective are immigration policies in increasing or decreasing the attractiveness of a destination country for highly skilled migrants? At the same time the quote is pertinent since the fear of the Swedish minister was brought up by an Indian public official, the joint secretary of the Ministry of Overseas Indian Affairs, showing that Indians are becoming well aware of the increasing number of options at their disposal.

As potential migrants look for the best country to live in, they will be interested in numerous socioeconomic and political factors in the destination countries that can work either as incentives or disincentives associated with a particular choice. Most of the factors, for example projected income, job availability or tolerance towards immigrants, are only loosely controlled by competing governments. Immigration policies have a direct objective to attract or repel certain type of migrants and can therefore be reassessed if found inappropriate. They thus form the easiest direct tool for governments to influence the migration flows. Yet, while reasonably comprehensive research exists on determinants of migration at the macro level (Beine, Docquier, \& Caglar, 2009; Docquier, Lohest, \& Marfouk, 2006; Karemera, Oguledo, \& Davis, 2000; Mayda, 2005; Ortega \& Peri, 2009), there is a lack of research on the role of the national migration policy and country-specific factors on micro incentives or disincentives to move internationally.

\subsection{Research aim}

This dissertation looks into the effect of government policies on the choice of a destination country for highly-skilled migrants, bearing in mind that the country choice of highly-skilled migrants may be more deliberate than that of migrants of lower skills and that the determinants of their migration may be different and reversed from those found in other forms of migration (Todisco, 1993; Todisco, Brandi, \& Tattolo, 2003). Some migration channels are directly guided by recruitment agencies or networks of transnational corporations. There are, however, many individuals moving independently outside of such steered channels and it is this specific group of migrants that this dissertation focuses on. The role of the state, with regard to immigration policies in particular, is still largely seen only as having an effect on international migration flows through controls and selective admittance of migrants that satisfy policy-defined targets. Such a view assumes an abundant pool of migrants, from which the state may select. However, highlyskilled migrants may choose among many different locations. In a context where individuals are able to choose based on their preferences rather than accept what 
they are offered, they become unprecedentedly active. Hence, states may need to alter their view of migration of the highly-skilled, to begin considering the individual as the selector rather than the one being selected by the state (Hercog, 2008, p. 19).

This thesis acknowledges this newly emerging perspective where the role of the state is seen as one about attracting potential migrants and considerations of migrants are put to the forefront. The question that this dissertation addresses is how the immigration policy and socio-economic environment in a receiving country attend to a potential highly-skilled migrant when the migrant is deciding where to go, choosing between several possible locations (Hercog, 2008, p. 19).

A multi-level approach is utilized, by observing society-level as well as individuallevel factors. First, theoretical analysis looks at the supply and demand-side factors in explaining location dynamics of highly-skilled migration. Furthermore, the elements of governmental policies are observed from the perspective of incentives and disincentives with an aim to make an inventory of all elements of the policy that might affect the destination choice. Besides observing the macro level, the research looks at the causal mechanisms of migration flows at a micro level. A quantitative survey and qualitative interviews in India enquire graduates at several universities on their perception of international mobility. The aim is to find out how personal characteristics, structural background factors, and expectancy-based perceptions are related to general intentions to move, and further, to destinationspecific migration intentions.

\subsection{Case studies}

In this study, I pay special attention to mobility of the highly-skilled to European countries as the new actors on the skilled migration playfield. Whereas the traditional immigration countries have long offered flexible admission criteria and attractive residence rights to highly-skilled migrants, it took Europe several decades to abandon the 'zero immigration' policies adopted after the 1973 oil crisis (Wiesbrock \& Hercog, 2010, p. 4). Shachar (2006) identifies the beginning of the race for talent in the United States already in 1965 with the introduction of 1965 amendments to the Immigration and Nationality Act (INA) ${ }^{2}$, which was then quickly, after two years, followed by Canada's original approach to admission criteria in a form of a point system. Following Canada's lead, Australia in 1973 and New Zealand in 1991 developed their own versions of a point system. Since then, policies of quality selective immigration have spread to other developed countries on a

\footnotetext{
${ }^{2}$ Immigration and Nationality Act 1965 Amendments, Pub. L. No. 89-236, 79 Stat. 911
} 
different scale. First to the U.S. with the Immigration Act of 1990 and the substantial relaxation of the quota for highly-skilled professionals (H1-B visas), and only then, with a delay of a decade or more, to European countries. Even though migration has always been a part of the European history, it has never turned into a part of national self-understanding as it has in traditional immigrant countries (Geddes, 2003). Immigration policies are evidently influenced and legitimized by labour market- and public finance conditions in a given country. Having that in mind, the main reasons for the change in the perceived need of opening the state borders is the necessity to boost Europe's competitiveness and economic growth in view of rapid population ageing (Bouvier, 2001). Predictions show that between 2010 and 2050 the EU's working age population is set to decline by 84 million people in a non-migration scenario and by 37 million people in a scenarios where migration continues at pre-crisis levels (Fargues, 2011). Although the so-called 'replacement migration' cannot single-handedly solve the European problem of shrinking labour force and ageing population, it is still increasingly recognised as a part of "policy mix", next to higher retirement ages, higher labour force participation rates of women and migrants, and active family policies (Münz, 2009). As such, European countries have become more and more involved in changing their labour migration policies in order to attract the migrants with occupations where skill shortages are evident. At the same time, tax contributions from migrants' employment are anticipated as benefiting the public finances.

While the regional focus at the receiving end is Europe, India was selected as the case study for the sending country. In terms of overall numbers of emigrants, India has been among the most important emigration countries in the world for many years. Indians abroad make up one of the largest diasporas and provide the second largest annual flow of current global migration, with China being first (Khadria, 2009). Indian emigration with a long history has always had an economic component and was linked with its colonial history to Britain. Today members of the diaspora are located all over the world, although the main regions are currently North America, Europe (mainly the United Kingdom) and the Middle East. Each of these regions attract different kinds of emigrants with the highly-skilled concentrating in North America and the low-skilled mainly migrating to the Middle East. Although the Indian experience with skilled migration has been quite well researched (Gayathri, 2001; Khadria, 2004, 2009; Purkayastha, 2005; Robinson \& Carey, 2000), there are new dynamics which have not attracted sufficient attention so far. Just a couple of years ago, a vast majority of skilled Indians were exclusively interested in migrating to the United States of America, but today their options are becoming more varied. Among others, Europe is emerging as a new destination. This is a rather recent phenomenon, taking off mainly in the 1990s and 2000s, a 
consequence of which is a particularly under-researched topic of migration between Europe and India. Some countries have clear advantages in attracting the Indian skilled population, in particular those that are English-speaking or have colonial links with India. Continental European countries have a much more disadvantaged position, due to several factors: the language, the use of which is mostly restricted to a small number of people outside of the countries, limited historical ties between these countries and India, short and limited history of skilled migration, and finally a small community network, which could pass on useful information on the destination country. All of these factors work unfavourably for Indians considering continental Europe as their prime destination for work or studies.

In order to counter these unchangeable factors, the Dutch government, for instance, in 2004 introduced a Knowledge Migrant Scheme with the aim to improve the current situation of a relatively low share of foreign skilled workers in the labour force. Increasing knowledge migration is considered an important strategy in becoming one of the most competitive and dynamic knowledge-driven economies. Since the introduction of the scheme, there has been a large increase in the inflows of Indians to the Netherlands. In the decade from 1995 to 2004, immigration from India accounted for around 600 to 700 people annually, and 1,320 Indians migrated to the Netherlands in 2005. This number further increased in the years after 2005, leading to 3,959 people migrating from India to the Netherlands in $2011^{3}$. Indians are by far the biggest migrant group who enter the Netherlands with the Knowledge Migrant scheme. Almost half of all residence permits for knowledge migrants are annually obtained by Indian nationals. Such increase in Indian immigration, possibly a result of the targeted immigration policy, has spurred the interest to study how decision-making about a chosen location can be influenced for a specific group of migrants.

\subsection{Concerns for developing countries}

When talking about skilled international migration, one cannot avoid addressing concerns about its effects on developing countries, specifically brain drain. The early literature (Grubel \& Scott, 1966; Johnson, 1967) on brain drain concluded that the welfare levels of those left behind would decrease if the migrants' contribution to the economy was greater than their marginal product. Since this seems to be the case when the social return to education exceeds its private return, and given that education is often at least partly publicly financed, it was widely recognized that the brain drain was detrimental to the migrants' source countries (Beine, Docquier,

${ }^{3}$ CBS Databank website, accessed June $4^{\text {th }} 2013$ 
\& Rapoport, 2003). This view, developed notably by Jagdish Bhagwati and his coauthors in the early 1970s (Bhagwati, 1976; Bhagwati \& Hamada, 1974; Bhagwati \& Wilson, 1989) submit that: i) the brain drain is basically a negative externality imposed on those left behind; ii) it amounts to a zero-sum game, with the rich countries getting richer and the poor countries getting poorer; and, iii) at a policy level, the international community should implement a mechanism whereby international transfers could compensate the sending countries for the losses incurred as a result of the brain drain; for example, through an income "tax on brains" (also coined the "Bhagwati tax") to be redistributed internationally. With the emergence of new growth theories and the strong emphasis put on human capital as a source of growth (Lucas, 1988), there has been a renewed interest in the study of the growth effects of the brain drain. The general view of the problem is that it would imply a significant economic and social loss if the best educated people made their contributions in a country different than their own. Building on this idea, the first models to address the issue of the brain drain in an endogenous growth framework all emphasized its negative effects (Haque \& Kim, 1995; Kanbur \& Rapoport, 2005; Miyagiwa, 1991). By contrast, the new brain-drain literature suggests that allowing migration of the highly-skilled from a developing country may actually increase the incentive to acquire education. Since not all people that have been encouraged to take up education due to emigration possibility actually leave the country, the stock of skilled workers will increase (Stark, Helmenstein, \& Prskawetz, 1998). This incentive effect (or brain gain) together with the positive feedback effects such as remittances and return migration after additional skills have been acquired abroad, have been put forward in the new body of literature on international skilled migration. However, worries about depleting developing countries of the scarce human capital are remaining and one of the seminal papers by Maurice Schiff (2005) concludes that the early brain-drain literature which viewed brain drain as entailing a loss for the developing source countries were close to the mark. Beine at al. (2003) add to the debate on brain drain by pointing out that there are losers as well as winners among the sending countries. On the one hand, countries which have high migration rates of highly educated and a high proportion of highly educated within the population indeed face negative effects on GDP growth. On the other hand, increased emigration would benefit countries with low rates of emigration and low levels of human capital. Although there are more countries facing negative effects, it is important to realize that the group of countries which are gaining from migration represent a much larger world population as these are the countries with the greatest demographic size such as India, but also China, Indonesia, Brazil and Pakistan. Small developing countries, conversely, lack the mass for agglomeration and other scale effects to exploit 
talented labour efficiently, which makes them particularly prone to high rates of skilled emigration (Commander, Kangasniemi, \& Winters, 2003).

Another important issue is the source of investment in migrants' education. Many people from developing countries have been trained abroad, so the claims of draining public resources do not hold on general terms. Moreover, often the once trained at home cannot be absorbed productively into their economies of origin. Unemployment among the educated is a problem in a number of countries. In case a person stays unemployed, the investment in education is lost to the economy. The migration therefore becomes an economic safety valve since it brings benefits to the migrant and possibly also to the economy when they send remittances or return at the later stage (Skeldon, 2005).

All in all, it is virtually impossible to draw general conclusions for implications of skilled migration on developing countries. Developing countries' circumstances clearly matter whether brain drain turns out as a curse or a boon (Commander et al., 2003). The country's size, quality of education, rate of skilled emigration, success of development policies, possibilities for agglomerations and other factors matter for the link between migration and development of a country. What is more, effects of migration have strong sectoral properties (Kuhn \& McAusland, 2006). Bearing in mind the complex implications that migration can have on development in sending countries, skilled migration from India has been shown to have overall positive effect, which is a pertinent reason for choosing India's science and technology sector as a case study.

\subsection{Structure of the dissertation}

The six following chapters form the substantive contribution of this dissertation, building up and progressing upon each other into a complementary total which should advance our understanding of destination choice processes and the role of government policies therein. The six chapters are thematically divided in two parts. The first part comprising of Chapter 2, Chapter 3 and Chapter 4, elaborates on questions: What determines migrants' destination choice? What elements of immigration policies work as incentives and what as disincentives for immigration? What is the legislation of the United Kingdom, the Netherlands and Germany in the field of immigration policies? What are the current policy developments in these states? The second part of the thesis, comprising of Chapter 5, Chapter 6 and Chapter 7, presents a case study of India as a sending country, including a quantitative and qualitative analysis aimed at understanding the drivers of student mobility from India. The main motivation behind the case study is to observe how 
potential future migrants perceive the destination options and how, in their perception, Europe fares in comparison with traditional immigration countries.

Chapter 2 sets the conceptual framework for this dissertation by showing why the issue of highly-skilled migration is so important in public debate. It describes the reasons why developed countries support increasing immigration. While selective immigration policies are still a rather recent phenomenon in Europe, it is important to point to their intertwined connection to the socio-economic context of receiving countries. Research literature also does not take the same stand on the role of the state in influencing migration flows. While some view immigration policies as "muddling along in the face of unpredictable migration pressures within institutional settings" (Sciortino, 2000), others consider the changed immigration policies as the main reason for outflows of skilled workers from poor to rich countries (Kapur \& McHale, 2005b). I discuss the problems linked to the regulation of immigration and provide a survey of the empirical literature on the effects of immigration policies. The presentation of existing empirical studies as well as an overview of existing theories on migration determinants from the position of a highly-skilled individual serve in function of finding policy elements and additional country-specific factors that work as incentives or disincentives to immigrate to a certain country. Based on this overview, the chapter concludes with a conceptual framework, which combines the implications of the theories for the role of the state in making the country more appealing for the professionals.

Chapter 3 addresses the question of how European countries can improve their position in the international competition for talents. In this context, we look at the existing legal framework on highly-skilled migration in three EU Member States and compare it with the labour migration policy of their main competitor country in the international competition for highly-skilled labour force-the United States of America. We have chosen three major EU immigration countries with recently introduced migration policies, targeting skilled migrant: the United Kingdom, the Netherlands and Germany. Existing literature in the field of comparative migration policies either opts for a detailed account of only a few case studies or for a systematic comparison of a number of policies by clearly specified criteria. One of these two qualities is chosen at the expense of the other. This dissertation aims to overcome this divide and combines the attributes of both approaches. It provides a clear disaggregation of policies into sub-categories as well as a detailed description of immigration policies. The number of cases chosen is purposely limited in order to allow for an in-depth evaluation of national policies. Moreover, we build on the comparative papers, e.g. (Cerna, 2008; Lowell, 2005), and select a clear list of criteria by which we disaggregate policies on the terms attached. The 
comparison is done by looking at five different aspects of policies, trying to assess the 'attractiveness' of EU and national rules for potential highly-skilled migrants: a) eligibility criteria, b) special provision for young migrants and options for former students, c) validity of permits and access to permanent residence, d) family migration options, e) employment rights and social security provisions. The choice for the selection of policy aspects is based on the conceptual framework developed in Chapter 2. Chapter 3 builds on two strands of literature. Besides adding to the debate on comparison of immigration policies, it also contributes to the convergence/divergence debate (Cornelius, Philip, \& Hollifield, 1994; Shachar, 2006; Zaletel, 2006). It explores whether, in a situation where many countries have the same policy goal of attracting and retaining the skilled labour force, we can actually observe convergence of immigration policies. The chapter also addresses the question of the added value of the Blue Card Directive for the entry and residence of highly-skilled workers in the European Union.

Chapter 4 presents the case study of the Netherlands in further detail, concerning its position in the competition for internationally mobile human capital. The reason for focusing on one particular country is to give an example of an open, knowledgedriven economy with an ageing population which has taken up a proactive approach in attracting workers with needed skills from abroad in order to alleviate the skills gap (Hercog, 2008, p. 19). The conceptual framework derived from the observed theories in Chapter 2 is applied to the case of the Netherlands. The Dutch immigration policy, other public policies and general conditions in the country are assessed in terms of attractiveness. The account of the legal framework of migration to the Netherlands, including the institutional set-up for immigration management, is presented in detail. The subsequent section describes the recent trends in immigration and places it in the framework of immigration policy developments. We specifically address the developments of migration from India to the Netherlands and present the current figures for stocks of Indian migrants.

The second part of the thesis focuses on the sending region and presents a case study of prospective migrants and their perceptions. Chapter 5 sets the research methodology undertaken in the case study of Indian students at five high-quality universities throughout India, observing crucial factors that influence students in their decision to migrate. It elaborates on the reasons why India was chosen as a case study of migrants' decisions and presents the methodology followed in the Indian case, including information on the specific research questions and hypotheses. The analysis of the quantitative survey is supplemented by results from qualitative interviews with a sub-sample of students from the observed universities, which gives further insight into the decision-making relevant to 
migration intentions. The first chapter of Part two gives an introduction to the research setting, the survey and qualitative data collection and furthermore presents the descriptive sample characteristics. Chapter 6 and 7 respectively answer the following research questions: a) what are the determinants to move abroad, and what determines the chosen destinations? b) are the determinants of migration to continental Europe different from determinants of migration to the United States or to other Anglo-Saxon countries (United Kingdom, Canada, Australia and New Zealand)? The specific attention of this dissertation is given to attractiveness of continental European countries in the global higher education and labour market. As a pole of attraction, a destination country has to actively pull the desired individuals, and for that purpose, it is necessary to comprehend to what these individuals respond best. By finding out students' perceptions of specific countries, a comparison is done with our earlier comparative policy analysis (Chapter 3 ). Chapter 3 shows the attractiveness of European migration policies as opposed to that of the United States. The analysis of migration aspirations and perceptions of potential destination countries among Indian students is valuable for addressing the main research question of this dissertation. A particular case study shows whether practices from the side of host country governments and from higher education institutions to bring in young talent from abroad resonate with potential movers and are in that way restructuring the geography of skilled mobility from India.

In Chapter 8, I revisit the main findings of both parts of the dissertation. Based on the findings of this research, I provide deliberations of policy implications regarding highly-skilled migration. This chapter completes the dissertation with the considerations of its probable limitations and suggestions for future avenues for research. 


\section{Policy Instruments: What Theory Teaches Us? ${ }^{4}$}

"Finding a general theory of migration with universal validity and applicability is the perpetual dream of those working on migration research. To the ambitious this has become an obsession; to the more realistic it has remained a fond hope." (Chang, 1981, p. 305)

\subsection{Introduction}

We acknowledge the newly emerging perspective and consider skilled migration as a supply-side problem where the role of the state is to attract potential migrants. The question that this chapter addresses is how the immigration policy and socioeconomic environment in a receiving country attend to a potential highly skilled migrant when one is deciding among several possible locations. We firstly present the reasons for supporting migration of the highly skilled in receiving countries. While the chapter explores the different ways to attract the highly skilled, it is important to revisit the main reasons for the perceived need for increased migration. Secondly, the role of the state and problems associated with the regulation of migration are discussed. Thirdly, the paper observes existing studies that consider the role of immigration policies as one of the determinants. The presentation of empirical studies on the effects on migration flows exerted by policies illustrates that policies matter but they operate in the context of other relevant factors. The fourth section aims to explore different theories on determinants of migration from the position of a highly-skilled individual. Each theory is observed with a purpose of finding policy elements as well as other relevant country-specific factors that can function as incentives or disincentives to immigrate to a certain country. Theories focusing on micro and macro factors affecting the migration decision are observed; however, more attention is given to theories that explain migration by focusing on a decision of the individual. The paper concludes with a conceptual framework which combines the implication of the theories for the role of the state in making the country more appealing for the professionals. Moreover, we focus on individual migrants and not on mobility of educated personnel within transnational companies, who are less subject to political and other kinds of constraint due to their use of organizational channels for migration.

${ }^{4}$ Some ideas in this chapter were also reflected in an earlier piece of: Hercog, M. (2008). The Role of the State in Attracting Highly-Skilled Migrants: The Case of The Netherlands. European Institute of Public Administration, EIPASCOPE, No. 3, 2008. 


\subsection{Reasons for encouragement of skilled migration}

While migration has been a constant element in the history of European countries, it has never become part of national self-understanding in the way as it has in traditional immigrant countries such as Australia, Canada or the United States (Geddes, 2003). Migration, in particular migration from outside of Europe, is perceived rather nervously as a threat to social cohesion within a state. Governments in the developed countries are becoming increasingly restrictive with regards to whom they allow to enter and remain within their borders. In European countries especially, policies aim to reduce the inflows of unwanted migrants. In contrast to increased openness for the movement of goods and capital, the movement of people to Europe is more difficult than ever. This pattern is called the "liberal paradox" of open markets and relatively closed states (Hollifield, 2000). Asylum-seeking migration, family-reunification or family-formation migrations have become increasingly unwanted and are more frequently the subject of restrictive policies. Quotas can be imposed for a particular category of migrants, they can be required to fulfil certain criteria, or the conditions under which the individual is admitted are so restrictive that it makes migration no longer viable. However, migration of individuals is sensitive to the ways certain people are viewed by the receiving states' actors at that particular point of time. The ways in which the governing actors view the world plays a decisive role in shaping migration policies and creating categories of migrants that are either wanted or unwanted. This is more likely to be connected to the way they are viewed by interest groups in receiving countries than by the characteristics these people actually possess. Recent encouragement of skilled immigration also needs to be seen from this standpoint.

The debate on needs for more skilled labour is predominantly defined by a small group with a high stake in this issue ${ }^{5}$. The successful effort of high technology firms in the United States to raise the annual quota for visas issued under the skilled temporary programme in 1999 is a good example of the intense lobbying campaigns that employers can launch to overwhelm labour opposition (Freeman, 2003). In general, increasing complaints of companies, especially in high technology sectors, about the shortage of adequately skilled workers led many developed countries to take new initiatives to admit more skilled labour migrants (Rothgang \& Schmidt, 2003). For example, in the Netherlands, pressure from Dutch companies resulted in the accelerated entrance procedure for highly skilled foreign workers.

\footnotetext{
${ }^{5}$ A pattern with concentrated benefits and diffuse costs is conducive to client politics. Freeman (2003)) argues that the concentrated beneficiaries (business and pro-migrant groups) have a greater incentive to organise than the diffuse bearers of the costs (general public).
} 
This line of thought that encourages a proactive approach to immigration is guided primarily by the economically oriented logic with the purpose of benefiting the receiving country. The concept 'priority workers' (Papademetriou \& Yale-Loehr, 1996) clearly expresses such a point of view, where the role of the receiving country is in defining and admitting highly skilled immigrants whose skills are considered to be attractive on national economic grounds. Immigration policies are obviously influenced and at the same time legitimized by the labour market and public finance conditions in a given country. Legitimizing immigration policies by using economic interests of the state is especially reasonable in the face of generally unsupportive public opinion of immigration. Skill bias of technological advancements, ageing of rich-country populations and globalization of production and trade are the three long-term trends most often cited as vigorously kindling international competition for talent (Kapur \& McHale, 2005a). Below, we briefly explain the ways each of the three trends contributed to the shift in demand for skilled labour.

Globalization of production and trade stirred support for a certain kind of immigration. Global production structures have led to movements of professional staff within transnational companies and increased demand for technical personnel at various locations. The changing organisation of production required transnational corporations to 'acquire and allocate high-level skills to direct and manage operations, and to provide specialist product and technical expertise at any of their sites worldwide' (Koser \& Salt, 1997). International division of labour also led to a concentration of high-level and specialist jobs in a few 'global cities' which in turn disproportionately attract highly-skilled migrants (Koser \& Salt, 1997). International competition for knowledge workers is bound to increase with broader globalization since skills are fundamental for both companies and states to be integrated and to compete in global economy.

Global economic changes and related sectorial shifts in employment explain part of the shift in demand for more skilled labour but these forces prove insufficient in explaining such a major shift. Existing studies show that much of the shift of labour demand is further explained by skill-biased technical and organisational change (Bresnahan, Brynjolfsson, \& Hitt, 1999). Recent technological advancements and increasingly integrated labour markets lead to an increased demand for a skilled labour force in most developed countries. Computerizing routine tasks permits substitution of certain kinds of human efforts but has proven limited in its scope for substituting more complex and demanding work. Skill-based technical change and related development of organizational infrastructure has shifted employers' demand from low- and middle-skilled toward more highly-skilled workers, which 
are extremely talented, autonomous, or have good management abilities (Bresnahan et al., 1999). The important role of the accumulation of human capital for the sustained economic growth is especially emphasized by the New Growth Theory (Straubhaar, 2000). According to this theory, highly skilled migration significantly contributes to the stock of human capital and, subsequently, to the economic growth of the receiving country. This holds in particular for certain sectors which are constantly facing labour supply shortages.

As patterns of skill supply and demand in Northern and Western Europe are shown in Figure 2.1, it is clear that the upper layers of the labour market portray larger demand for migrant labour as well as the fact that the supply of national labour does not correspond to the given technological and production possibilities (Böhning, 1996).

Figure 2.1: Patterns of skill supply and demand, Northern and Western Europe, 1990

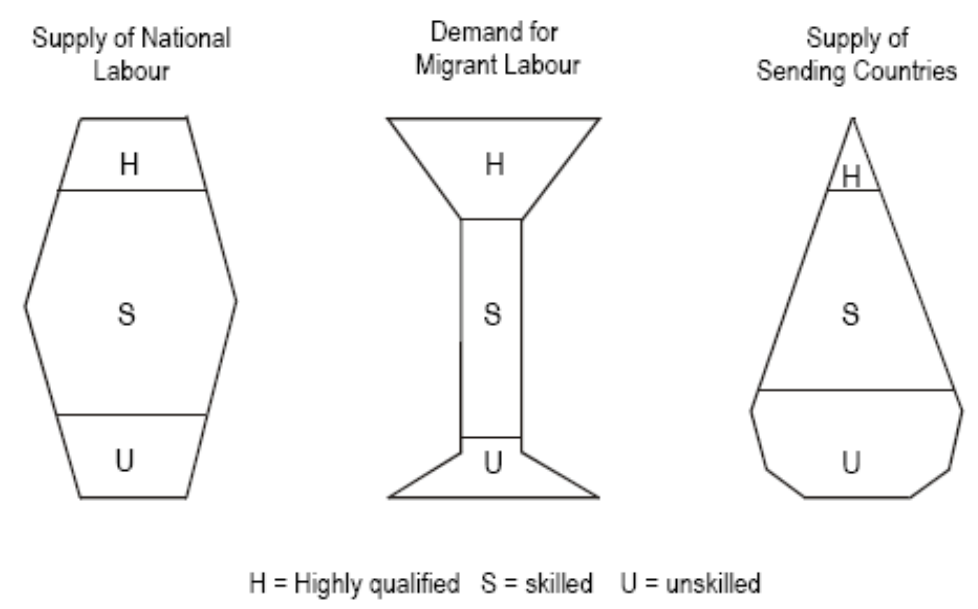

Source: Stalker (2000)

Such mismatch occurs for various reasons. Insufficient numbers of people have been drawn into a specific economic activity or a country's education and training system has not (yet) produced particular skills (Böhning, 1996). Despite the fact that the supply of local high-skilled workers has highly increased in the recent decades, there is an increasingly widespread perception among governments and employers in developed economies that there is a need for more skilled labour from abroad.

The third trend that stimulates the need for more immigration is population ageing. Geddes (2003) emphasizes the ways in which welfare state pressures and changed 
welfare state ideologies affect the perception of migrants in European countries. These pressures determine why some categories of migration are rejected as being portrayed as a drain on resources. In the face of high fiscal costs of an ageing population, attempts are being made to attract high-earning foreign workers and taxpayers at the same time. This is seen only as a short-term solution since nowadays foreign workers themselves become entitled to benefits in the future and represent a further drain on resources.

\subsection{The role of the state in migration flows}

Under conditions of demographic ageing, efficiency-based globalization and technological advancements, immigration of highly-skilled workers is generally considered to have positive effects on states. They are believed to contribute to the destination states in a number of ways and are therefore encouraged to come. In line with that, we can more than ever observe global competition for internationally mobile highly skilled workers. The competition, often referred also as a 'battle for brains', takes place among companies, cities, regions and countries. Although Krugman (1996) argues that competitiveness only takes place between companies, there is a growing acceptance on the side of government policies as well as on the side of migration theories that competition to attract potential employees occurs also between countries. Kapur and McHale (2005b) even consider the increasing skill-focus of immigration policy in the leading industrialized countries as a leading cause for the growing flows of human capital from poor to rich countries. Nevertheless, as the impact of migrants on the structures and functioning in the state is not well understood, research literature also does not take the same stand on the role of the state on influencing migration flows. In the following section, we briefly discuss the problems associated with the regulation of immigration and provide a survey of the empirical literature on the effects of immigration policies.

Despite the debatable role of the state in migration flows, all states intervene in the process of international migration and in this way try to affect the volume and composition of migrant flows. Many argue that the forces behind international movements of people are so powerful they render governmental efforts inefficient. As Sciortino (2000) describes, migration policies are often muddling along in the face of unpredictable migration pressures within institutional settings that do not facilitate the translation of policy objectives into policy outcomes. Regulation of 
immigration ${ }^{6}$ is particularly difficult since public policies aim to regulate behaviour of nationals other than their own. The capacities of receiving states to regulate immigration are especially difficult for the unwanted flows. Liberal democracies use mainly legal and administrative tools to regulate the flows, which are never fully effective. Thus, there is an inherent powerlessness in their functioning. Such weaknesses affect the public perception of governments' ability to control the boundaries of state territory, which is an integral part of sovereignty. Governments therefore claim to be able to manage international migration and to make it appear as if they are in control of who enters and who stays within their borders.

Several studies attempt to observe the effectiveness of the immigration policies, most often by comparing the outcomes of immigrants in Canada and the United States. While most studies point to the effects of different immigration regimes, they disagree about the kind of impacts they have and also about the importance that policy changes have on inflows. Wright and Maxim (1993), for instance, demonstrate that the specifics of Canada's immigration policy have an effect on the type of immigrants that are attracted. The restructuring of the immigration system in 1967 brought about the changing of the source of Canadian immigrants towards developing countries and an increase in the share of family class and refugee immigrants. Green and Green (1995), likewise, point to an impact of immigration policy changes in 1967 in determining the nature of the inflow. This examination shows a shift away from less skilled categories towards professionals. Borjas (1993) also concluded that the Canadian immigration system leads to a change of countryof-origin mix, which in turn has favourable effects on immigrant outcomes compared to immigrants to the US. Contrary to this conclusion, the analysis by Antecol, Cobb-Clark and Trejo (2003) does not support the view that the skills of US immigrants would improve if the United States were to adopt an immigration point system similar to systems in Australia and Canada. Similarly, Cobb-Clark and Connoly (1997) argue that policies are likely to exert a limited effect on the concentration of migrants. Their study suggests that skilled migrants wanting to enter Australia are influenced by a range of factors. Some of the factors are internal to Australia, while others are external, for example, immigration policies of other countries. They claim that these factors are likely to have more impact on immigrant quality than the point system.

\footnotetext{
${ }^{6}$ Almond and Powell (1978) distinguish policies of extraction, policies of distribution, policies of regulation and symbolic policies. Immigration policies belong mostly to the policies of regulation, "the exercise of control by a political system over the behaviour of individuals and groups in the society". In the case of immigration policies, such control is exercised over foreign nationals wanting to enter the country or those that have already migrated, which makes the regulation that more difficult.
} 
Mayda (2005) empirically investigates economic and non-economic determinants on international migration. Factors, such as geography, demographics and network effects are incorporated in the paper and prove to be consistent with theoretical predictions. An important contribution of the article is in its claim that immigration policies do matter. They are also discussed as an explanatory factor for migration. However, they are used in a sense of restrictive policies that have an effect on neutralizing push factors or intensifying pull factors in a receiving country. When policies are less restrictive, the impact of pull factors becomes more positive.

Clark, Hatton and Williamson (2002) explain the changes of migrant composition in the United States through time using a number of variables, including indirect costs associated with quantitative policy restrictions on migration and skill-selective immigration policies. ${ }^{7}$ The results show that economic and demographic variables, the immigrants' stock and policy-related variables all emerge as significant determinants of migration rates as predicted by the theory. Although the conclusions reaffirm that immigration policy had powerful effects on the volume and composition of US immigrants between 1971 and 1998, the authors still stress the importance of fixed effects, such as distance and proximity.

Docquier, Lohest and Marfouk (2006) analyze the location choice of international migrants to OECD countries, testing for behavioural differences across education groups. Their results show that immigration policies matter. Countries with similar immigration policies are included as a set of dummies, so that Canada, New Zealand and Australia are grouped together, with the US as the second dummy and EU-15 as the last dummy. The results show that EU policy favours unskilled migration and discourages skilled migration. Doquier et al. argue that policies can modify the structure of immigration but the other driving forces still operate. In line with the general evidence suggesting that migration policies manage better to influence the composition of migration rather than the overall volume (Czaika \& De Haas, 2011), Beine, Docquier and Ozden (2009) find that Schengen agreement between two countries, which entitled their citizens to travel freely in each other's territory without a visa, did not significantly affect total migration flows but has a connection with a higher share of high-skilled migration.

Gross' (2006) contribution to evaluating the impact of immigration policy on the structure of migration flows is by observing changes in immigration to Switzerland from the former Republic of Yugoslavia during two different periods, from 1981 to 1995 and from 1995 to 2003 . When immigration became severely restrictive for

\footnotetext{
${ }^{7}$ US immigration policies are captured by the use of the number of quotas or visas for different immigrant categories.
} 
non-EU workers in the mid-1990s, financial and cultural incentives became less important for immigrants from the former Yugoslavia, which is typical for skilled migration. Such change in migration factors thus corresponds with the change in skill composition of the group, which resulted from the policy shift.

While most papers include the policy effect in terms of its restrictiveness on migrant flows and hence on migrant composition, Gross and Schmitt (2006) added to the debate by looking at policy also in terms of its incentive effect. While analysing France, they find that higher income per capita and skill-related premium continue to impact high-skills flows while free mobility has little effect. In addition, there are differences between high-skill migrants from transition and developing countries and those from high-income countries; while the former respond to increased standards of living and non-pecuniary benefits, the latter move solely for higher skill-related premiums.

While there are differences between migrants at the skill level as well as at the country of origin level, Mahroum (2000) accentuates the need to take a differentiated approach to analyse migration drivers for specific professions. He developed a typology of highly-skilled mobility and maintained that groups of professions react to different push and pull factors and hence different immigration and non-immigration policies should be introduced to encourage their mobility. As shown in Table 2.1, some groups of professionals, like managers and executives, follow financial rewards for their relocation, while academics and scientists as well as students are mainly motivated by research and working conditions and the reputation of the host institution. This has implications for the role of the state in influencing the flows of highly-skilled persons, as different policies appeal to different groups. Corporate policies are most relevant for managerial and executive staff as they move mostly as a result of international business expansion. Engineers and technicians are pulled by economic factors; they are in particular responsive to labour market supply and demand signals and follow the best economic offers. In addition to immigration legislation, other non-immigration legislation, such as income taxation and bureaucratic efficiency, are relevant when it comes to luring diverse groups of skilled professionals. 
Table 2.1: A classification of highly skilled mobility, types of influencing factors and policies

\begin{tabular}{|c|c|c|}
\hline Groups & Types of push and pull factors & Types of policies \\
\hline $\begin{array}{l}\text { Managers \& } \\
\text { Executives }\end{array}$ & Benefits and remuneration & Business-oriented \\
\hline $\begin{array}{l}\text { Engineers } \\
\text { \&Technicians }\end{array}$ & $\begin{array}{l}\text { Economic factors (supply and demand } \\
\text { mechanisms) } \\
\text { The state of the national economy }\end{array}$ & $\begin{array}{l}\text { Immigration legislation } \\
\text { Income tax }\end{array}$ \\
\hline $\begin{array}{l}\text { Academics \& } \\
\text { Scientists }\end{array}$ & $\begin{array}{l}\text { Bottom-up developments in science } \\
\text { Nature \& conditions of work } \\
\text { Institutional prestige }\end{array}$ & $\begin{array}{l}\text { Inter-institutional and } \\
\text { Intergovernmental policies }\end{array}$ \\
\hline Entrepreneurs & $\begin{array}{l}\text { Governmental (visa, taxation, } \\
\text { protection, etc.) policies } \\
\text { Financial facilities } \\
\text { Bureaucratic efficiency }\end{array}$ & $\begin{array}{l}\text { Governmental and regional } \\
\text { policies } \\
\text { Immigration legislation }\end{array}$ \\
\hline Students & $\begin{array}{l}\text { Recognition of a global workplace } \\
\text { Accessibility problems at home } \\
\text { Inter-cultural experience }\end{array}$ & $\begin{array}{l}\text { Intergovernmental, } \\
\text { and inter-institutional } \\
\text { policies } \\
\text { Immigration legislation }\end{array}$ \\
\hline
\end{tabular}

Source: Mahroum (2000)

The overview of empirical literature shows that the research places great emphasis on the effects of immigration and other governmental policies on the international mobility of people. These studies illustrate that state policies have an effect on the skill composition of migrants although other determinants, such as history, geography and economic incentives, remain significant. Since most of these factors are only loosely controlled by competing governments, it is important to focus on factors that can be manipulated in order to lure skilled workers who are deciding where to migrate. Accordingly, the next section observes the theories on determinants of migration and provides an overview of possible policy interventions that would incentivize migration to a certain country.

\subsection{Overview of theories on determinants of migration}

In this part, migration theories are observed from a supply-side perspective. As more countries recognize the positive impacts of immigration, they are not only allowing for increased inflows but are also assessing how best to incentivize both entry and settlement (McLaughlan \& Salt, 2002). To provide an insight into how migrants choose their destination, this article analyses migration theories that deal with determinants of migration. Theories focusing on micro and macro factors affecting the migration decision are observed; however, more attention is given to 
theories which explain migration via the aspirations of individuals. Furthermore, the considerations of migrants are put to the forefront, bearing in mind Todisco's findings (1993) that the country choice of highly skilled migrants may be more deliberate and that determinants of migration may be reversed from those found in other forms of migration.

A general view which integrates other theories of labour migration discussed below can be given by the push-pull approach, which sees migration as determined by positive factors in areas of destination and negative factors in the place of origin (Skeldon, 2005). In low-income countries, political, economic and social push factors abound: political instability, insecurity, oppression and poor housing, inadequate social services and education facilities for children. In addition to low salaries, shortages of supplies and work overload are part of unsatisfactory working conditions. On the other hand, certain socio-economic conditions in the destination countries have to allow for increased demand for imported labour. Such demand is fuelled with the ageing of rich-country populations and with the need for skills in knowledge-based industries.

\subsubsection{The neoclassical theory of migration}

The oldest theory of migration is the neoclassical theory of migration (Harris \& Todaro, 1970; Todaro, 1969), which has been empirically confirmed by a large number of papers (Clark et al., 2002; Mayda, 2005). It posits that people migrate to areas with a higher wage level. Countries with a shortage of labour relative to capital have a high equilibrium wage, while countries with a large supply of labour have low wages. The wage differentials between the locations lead to migration of labour from low- to high-wage areas. Shortages of skilled labour in many developed countries are thus overcome by higher wages which result from increased competition. According to the neoclassical theory, wages adjust the demand and supply and thus alleviate the skills shortages. The micro-economic equivalent to this theory considers the migrant as a utility maximizing agent who will migrate when one expects a higher utility in a different location, net of migration cost. Individuals compare locally expected earnings with their expected earnings at different destination countries. As such, the theory foresees that individuals with specific features are more prone to migration. Migration is a self-selective process, in which those that are the most likely to benefit from migration self-select themselves into this activity (Cattaneo, 2007). 


\subsubsection{The human capital theory}

Most theories acknowledge the importance of economic factors in migration decisions but also concede that they do not cover all events which trigger migration decisions. The importance of subjective factors was recognized by some of the earlier migration scholars. The human capital theory, which is based on the neoclassical theory of migration and was first proposed by Sjastaad (1962), sees migrants weighing benefits and costs on the basis of their own human capital. While the basic migration model considers good employment and wage opportunities in the host country as the crucial draw, the human capital theory expands on that and emphasizes the expectations of a migrant. Non-monetary costs and benefits are taken into account as well. Providing that migration is not influenced exclusively by incomes and employment opportunities, governments therefore have more space for creating an attractive environment. Hence, living conditions importantly influence the attractiveness of a country. As Massey et al. (1993) put it, immigration can occur even when earnings in a receiving country are not higher if the new living conditions look particularly attractive. Since the expectations of a migrant play a fundamental role in the decision to migrate, it is the signal that a country sends out which matters in a migrant's decision-making. A positive signal can be sent out in a number of ways; through official recruitment advertising or in more indirect ways, such as having good employment records for immigrants. An immigration policy itself might serve as a signal for migrants that their skills are welcome and subsequently highly rewarded in the destination country's labour market.

An important aspect of the human capital theory is that people make their decisions taking into account their personal positions. Accordingly, higher returns are realized in the migration of better-educated, younger people. Better-educated people in general receive higher salaries and for young migrants, it holds that the period to reap the returns on their investment associated with the migration decision will be longer. Since migration often also requires occupational upgrading or change of qualifications, it is more valuable for young persons to invest in migration. Since their returns depend on the length of staying in a receiving country, it is relevant for a migrant to gather the benefits of migration for a longer term. Since the human capital theory predicts that the educated young are the most likely to migrate, governments should focus their policies on this target group. For instance, the conditions for entry should be adjusted for younger migrants. In addition, governments should bear in mind that the timeframe of the validity for a residence permit can play a role in making their country more attractive. If there is a time limit, it is relevant to consider if it is possible to extend the permit or convert 
it to permanent status. In case there is no clear indication that the immigration policy allows for permanent settlement, migrants will be less likely to move to that specific place and invest in acquiring country-specific human capital, like learning the host-country's language.

Since future returns from moving to a different location strongly affect the migration decision, the opportunities for career advancement play an important role. Therefore, opening up opportunities for migrants to access high-level positions and providing prospects for professional development by making use of good-quality training has an effect on the attractiveness of a country for migratory purposes.

\subsubsection{Family migration theory}

The theories mentioned above assume completely individualistic assessments of migration decisions. However, new migration literature clearly indicates that migration is often a household choice. The theory of economics of family migration, developed by Mincer (1978), as well as the 'new economics of labour migration', developed by Stark and Bloom (1985), see migration as a decision taken within families and households. Family migration theory states that a household will only migrate when utility gains of some of the household members exceed the utility loss of other household members (Mincer, 1978). Acknowledging that the family is the decision-making unit, equal importance has to be placed to the considerations of both partners. That is especially the case for highly-skilled workers, since they are in many cases members of dual-career couples. Research has shown that job relocation is a stressful event for employees (Anderson \& Stark, 1985; Munton, 1990) and even more for 'trailing spouses' (Harvey, 1995; Martin, 1996). Potential problems for spouses are often similar to those of moving employees but can also include other inconveniences. The spouse may: 1 ) lose social support provided by extended family and friends; 2 ) experience significant adjustment due to loss of professional identity; 3 ) have problems associated with the family unit due to the children's unwillingness to relocate; 4) have difficulty in finding employment during the relocation; and 5) experience significant stress due to professional isolation and loss of career (Wiggins-Frame \& Shehan, 1994). Greenbury and Shortland (1996) name the following problems that a spouse could face: work permit restrictions, lack of job opportunities abroad, language and cultural differences, lost promotional opportunities, lack of transferable skills, and financial implications. The relevance of this theoretical insight for the consideration of the governments pertains to the possibilities for family reunion and access of a spouse to the labour market. Considerations for family members have to be taken into account by 
allowing spouses to accompany the principal migrant and further, by giving them access to work. Liebig (2003) further expands on the importance of the family as a decision-making unit by recommending good schooling opportunities for children's present well-being as well as for their later income. In a case of a dual-career couple, it is also relevant to provide day-care services for children.

\subsubsection{The 'New Economics of Labour Migration'}

The impact of characterizing the decision-making unit as a household is extended further by the "New Economics of Labour Migration," which emphasises the risksharing behaviour. Migration decision can be seen as a way to maximise household income while at the same time trying to minimize the labour markets' risks for the household. Contrary to the family migration theory, family members do not move to a new location. Migration, therefore, offers an opportunity to diversify risks by allocating family members to different settings. Especially for people from developing countries, international migration offers the means to overcome missing or failed markets for capital, credit, and insurance (Stark, 1991). When receiving countries' conditions are to some extent independent of economic conditions in the sending country, migration is considered insurance against deterioration. In this context, a country that provides ways to overcome the market failures via mechanisms other than offering higher incomes becomes relatively more attractive. For those highly skilled people that migrate due to risk-diversifying strategy, a country will become more attractive when it provides more security for migrants and their families.

Likewise, the "welfare magnets theory" as presented by Borjas (1999) says that once migrants are self-selected, they can choose the destination country where public assistance is the highest. When Docquier et al. (2006) analysed the location choice of international migrants to OECD countries they found that social welfare programmes encourage concentration of both unskilled and skilled workers. Access to social security provisions for migrants, such as health insurance, child benefits and employment protection, therefore plays a role in making a destination country more attractive. In addition, it is increasingly recognized that governments hold an exclusive power over the allocation of citizenship. Acquiring citizenship in a stable, democratic and affluent polity is especially important for those migrants moving from poorer and less stable countries. In this way, "the citizenship factor becomes a recruitment tool for advanced industrial polities" (Shachar, 2006).

The "New Economics of Labour Migration" also draws attention to the role of transaction costs in determining migration choice. Transaction of human capital depends largely on the types and levels of skills. Skills in technology-intensive 
sectors have much more global character and are more easily transferable across different countries than, for instance, skills and knowledge in social sciences. In general, transaction costs increase with the skills level but also with the countryspecificity of said skills. Recognition of migrants' education qualifications or other job-related achievements therefore bears crucial relevance for migration decisions of the highly skilled. To promote the geographical mobility of skilled workers across countries, governments should thus strive for more transparency of international recognition of skills. Countries that have developed efficient ways to evaluate previously obtained skills and certify credentials in an efficient manner would therefore be more appealing to skilled workers.

Several papers on immigrant integration show that language skills bear an important contribution to the performance of immigrants in the receiving countries' labour markets (Chiswick \& Miller, 1999) and therefore indicate that language barriers work as an important obstacle for reaping returns to human capital investment in a destination country. To reduce the transaction costs due to language barriers, a country can offer preparatory language trainings or make the application procedures easier, by offering documentation and application forms in several languages.

\subsubsection{Migration network theory}

Contrary to the theories described previously, Tilly (1990, p. 84) says that neither individuals nor households are the effective units of migration; rather, that migratory units are "sets of people linked by acquaintance, kinship, and work experience." The presence of social networks and access to them also plays a role in mobility behaviour (Massey et al., 1993). Much of the movement of skilled migrants from the developed world goes through these networks. Ties between migrants in a receiving country and people in a home country increase migration probability as these connections reduce the costs and risks of migration. At the same time, these networks increase future gains. They can be considered a form of social capital utilized by migrants to get access to information as well as other support for immigration and integration in the host country. The role of the state in making a country more attractive for skilled migrants is not obviously detectable in the migration network theory, however networks can also be created or at least facilitated by fostering links between highly skilled domestics and those abroad. Supporting international cooperation of research institutes and encouraging student exchange programmes are just two examples of ways to create networks.

Information promoting the migrant network theory can be also be obtained from a person's own experiences with mobility. A person who has previously travelled to 
other countries is consequently more knowledgeable about international travel generally (and those countries specifically), resulting in an increased likelihood of migration. Experiences with mobility increase the information available and hence reduce the cost and risks of future mobility as well as facilitate adaptation. Several studies find that studying abroad significantly increases an individual's probability of working in a foreign country (Li, Findlay, Jowett, \& Skeldon, 1996; Parey \& Waldinger, 2008; Salt, 1997). Since student exchange mobility acts as an important determinant of later international labour market mobility, many countries attempt to attract highly skilled mobile workers through policies relating to student mobility programs. Facilitating the stay of foreign students that graduated from institutions in the host country is another manner of creating a new migrant network that would then induce further highly skilled migration.

\subsubsection{The amenity literature}

The amenity literature (Graves, 1979; Graves \& Linneman, 1979; Graves \& Regulska, 1982; Krupka, 2007) gives another valuable contribution to the supplyside perspective on migration. The local characteristics, also referred to as amenities, affect the quality of life because people have preferences for certain types of areas; for example, areas that offer more security, better access to facilities, more moderate climate, and so forth. Taking this into account, governments have a variety of options for creating amenities that significantly improve the quality of life. The state needs to work not only on 'hard' migration policies which are targeted exclusively at immigrants but also on 'soft' policies which matter also for migrants but are meant for society as a whole (Wickham, 2008). An effective public transportation system is, for instance, an important quality of a particular locality because it makes the locality more appealing for living and settling down. Especially when considering that skilled people value specific kinds of amenities, effort should be expended to create an environment that responds to their demands, such as, for example, offering a significant amount of cultural activities.

An important contribution to the amenity literature is Florida's creative class theory $(2002,2005)$, in which creative classes move to areas with attractive lifestyles and a tolerant atmospheres. In turn, regions with large numbers of creative people attract investments in technology-intensive industries. According to Florida (2002), in order to attract a creative class, a region must have three dimensions of competitiveness: technology, talent, and tolerance ( $3 T^{\prime}$ s). In addition to traditional measures which increase the quality of place, Florida calls for improving the general climate by creating and catering to tolerance and diversity. In view of that, 
promoting cultural diversity and influencing national attitudes to ethnic diversity can be a part of a national policy to appeal to potential migrants.

\subsubsection{Self-selection process}

The next important issue raised in migration theories is the self-selection process. Borjas (1987) explains the incentives of individuals to migrate to different locations by analysing the dispersion in earnings distributions. When the wage distribution in the host country is more unequal than in the sending country, self-selection will be positive, meaning that the highly-skilled will be motivated to migrate since the sending country values skilled workers less than the receiving country. In order to attract highly-skilled migrants, this theory gives limited scope for government interventions as it is not likely that more inequality will be encouraged to pursue positive self-selection of migrants.

However, there are different ways to make returns to skills more progressive. One such way is the introduction of a taxation regime that is favourable to high earners. A number of studies have supported that people with high income prefer to move to regions with lower taxation (Feld \& Kirchgässner, 2001; Kirchgassner \& Pommerehne, 1996; Liebig \& Sousa-Poza, 2005).

\subsubsection{Structural theories}

So far we have assumed either an individualistic or a group decision-making process of migration where a migrant's agency is the main factor. Although this paper supports the perception of migrants as active selectors of a destination country, we must take into account the political, economic and cultural structures of countries of origin and host countries that surround the decision-making process. Theories such as the migration systems theory (Fawcett, 1989; Kritz \& Zlotnik, 1992) or the historical-structuralist theory (Frank, 1966; Wallerstein, 1974) explain migration using the existence of prior links between sending and receiving countries, and thus do not allow for much manoeuvring on the side of migrants. The world systems theory developed out of historical-structural theory puts migration in a structurallyunbalanced context of the core capitalist countries and countries that are in the periphery of the core. It is assumed that cultural links motivate people to move from the periphery to the core, especially from former colonies to the past colonial powers. Historical roots of enduring cultural ties are visible in the education systems of former colonies and languages of instruction which are just two factors attracting migrants to their former colonizers.

Migration systems approach also emphasizes the context in which migration takes place. A particular context makes countries in a migration system connected not 
only by people but also by other types of linkages. Kritz and Zlotnik (1992) distinguish the linkages between countries into historical, cultural, colonial, and technological. Docquier et al. (2006) show that colonial ties and linguistic barriers matter more for unskilled migrants, but results show that they are also significant across different skill levels. Geographical and cultural proximity between the host and the sending country determine the flows and can hence explain the concentration of a majority of migrants living in just a few destination countries. Distance has a particularly negative effect on the concentration of skilled migrants.

Theories emphasizing the structural level can help to explain why the role of the state in influencing migration flows proves to be difficult and is often questioned. When developing an active immigration policy, the government should therefore be aware of the structural factors at work. Nevertheless, the context of migration and linkages between countries can, to some extent, change through time. New and stronger linkages can also be created and supported.

\subsection{Combining the implications of the theories for the role of the state}

A number of theories have been presented that show different ways of influencing a migrant's decision about the destination country. While good employment and wage opportunities in the host country are crucial factors, there are many other ways the state can play an active role in attracting mobile workers to their labour market. Table 2.2 in the Appendix presents a systematic overview of all mentioned theories, including their policy implications.

The expectation of a migrant to see a potential host country as an attractive destination can be boosted by recruitment agencies, advertising and efficient application procedures. Positive signals can be sent out by giving opportunities for foreigners to access good positions in the labour market. Providing prospects for professional development is an important aspect for career-oriented people that decide to move for job related reasons. Also, the possibility to settle in a country and reap the investment related to migration for a longer period of time is a factor in destination choice. Thus, the time frame of the residence permit and the possibility to convert it into permanent settlement influences migrants' decisions when choosing where to emigrate. Investment in country-specific human capital, for example, the language of the host country, is more likely when migrants have the prospect to stay there for a longer period of time. Regulatory tools have to take into consideration both partners and also the fact that migrants often bring their children. Immigration policies should allow for generous possibilities for family 
reunification and also permit spouses of principal migrants to access the labour market. Good schooling opportunities and day-care services for children play an important role when the family is a decision-making unit on migration. More social security and provision of public goods, in general, makes a country more attractive. Especially for people from developing countries, migration to a more developed country offers an instrument to overcome market failures in their home countries. Access to social security provisions for migrants and their family members therefore plays a role in making a destination country more attractive. Countries that are more generous in offering health insurance, child benefits and employment security enjoy a considerable advantage compared to other destination countries.

Fiscal incentives are another way to motivate skilled workers since they usually receive high salaries. Returns to skills can be made more progressive by a favourable taxation regime. In several countries, highly skilled immigrants either have tax-free status for a number of years after having migrated (for example in Australia for four years) or they have significant tax reductions.

Another way of competing for the skilled workers is by offering efficient and transparent recognition of qualifications obtained abroad. Many countries have already realized that past mobility encourages future mobility and therefore aim to attract highly skilled mobile workers through policies relating to student mobility programs (Guellec \& Cervantes, 2002). Attracting students to a host country's higher education institutions initially and then allowing and encouraging them to find a job in their labour market is a way of increasing the pool of highly skilled people. Student exchange programmes are also a way of creating networks with skilled people from abroad. Supporting international cooperation of universities and research institutes is another way of establishing social networks that might work as triggers for mobility of staff. In order to reduce language barriers, it is important that foreign students have the option to take courses in international languages. Especially for countries that have a disadvantage in the language commonly spoken, investments should be made in language trainings. Additionally, application procedures should be made available in several languages.

\subsection{Conclusion}

As we acknowledged earlier by pointing to the theories and prior empirical research, there are certain structural factors in migration flows that are difficult to overcome with the intervention of the state. Some structural forces, such as geographical proximity and colonial links between countries, cannot be altered. Nevertheless, these structures can be at least influenced by changing the 
institutional settings, such as internationalizing of higher education. Table 2.2 illustrates that the state can intervene in the migration flow of high-skilled people in ways beyond tailoring migration policies to their needs. One way is for the state to influence the institutions that provide the link between potential migrants and employers. Countries can sign bilateral agreements with respect to highly-skilled migrants. Since structural forces explain a big part of migration, effort can be made by the state to influence the political, economic and cultural relationships. Creating social networks by fostering exchange is a way of changing the existing structure. Internationalisation of the education system is considered very positive since it provides the infrastructure that attracts foreign students and it also increases retention by providing possibilities for finding employment in the host country's labour market.

Despite the intended messages that state-enacted policies are sending to the public, we can still assess how these policies influence migration flows. We must be aware that policies typically reflect the public's expectation. This pattern is especially present in times of increasingly negative feelings towards international migrants. Bearing in mind that it is particularly difficult to regulate immigration for unwanted flows, the attention is now refocused on the immigrants that a country wants to attract for its own benefits. In this way governments present themselves as being able to manage international migration and make it appear as if they are in control of the process. The purpose of this chapter is to show the different ways a state can cater to highly skilled people and influence their decision on location choice. However, it remains unclear to what extent the accepted policies attract the wanted migrants. 


\subsection{Appendix}

Table 2.2: Overview of theories and implication for the role of the state

\begin{tabular}{|c|c|c|}
\hline $\begin{array}{l}\text { Theories of determinants } \\
\text { of migration }\end{array}$ & Determinants & $\begin{array}{l}\text { Implications for } \\
\text { attractiveness of a state }\end{array}$ \\
\hline $\begin{array}{l}\text { The neoclassical theory of } \\
\text { migration } \\
\text { Todaro (1969), Harris and } \\
\text { Todaro (1970) }\end{array}$ & Higher wage levels & $\begin{array}{l}\text { Employment opportunities } \\
\text { Efficient and transparent } \\
\text { application procedures }\end{array}$ \\
\hline $\begin{array}{l}\text { The human capital theory } \\
\text { Sjastaad (1962) }\end{array}$ & $\begin{array}{l}\text { Future expectations of } \\
\text { migrants based on their } \\
\text { personal characteristics }\end{array}$ & $\begin{array}{l}\text { Advertising immigration } \\
\text { options } \\
\text { Opportunities for career } \\
\text { advancement } \\
\text { Targeted policies for younger } \\
\text { migrants } \\
\text { Enabling permanent } \\
\text { settlement or extendable } \\
\text { periods of stay }\end{array}$ \\
\hline $\begin{array}{l}\text { The theory of economics of } \\
\text { family migration } \\
\text { Mincer (1978) }\end{array}$ & $\begin{array}{l}\text { Utility gains for all family } \\
\text { members }\end{array}$ & $\begin{array}{l}\text { Possibilities for family } \\
\text { migration } \\
\text { Access of a spouse to the } \\
\text { labour market } \\
\text { Schooling opportunities; Day- } \\
\text { care services for children }\end{array}$ \\
\hline $\begin{array}{l}\text { The New Economics of } \\
\text { Labour Migration } \\
\text { Stark and Bloom (1985), } \\
\text { Stark (1991) }\end{array}$ & $\begin{array}{l}\text { Risk sharing among family } \\
\text { members } \\
\text { Transaction costs }\end{array}$ & $\begin{array}{l}\text { Access to social security } \\
\text { provisions } \\
\text { Standards for validating skills } \\
\text { and previous experiences } \\
\text { Reducing language barriers }\end{array}$ \\
\hline $\begin{array}{l}\text { Migration network theory } \\
\text { Massey et al. (1993) }\end{array}$ & $\begin{array}{l}\text { Presence of social networks } \\
\text { abroad }\end{array}$ & $\begin{array}{l}\text { Fostering international } \\
\text { cooperation of professional } \\
\text { staff } \\
\text { Encouraging student } \\
\text { exchange } \\
\text { Facilitating stay of foreign } \\
\text { students after the graduation }\end{array}$ \\
\hline $\begin{array}{l}\text { Amenities literature } \\
\text { Graves and Linneman } \\
\text { (1979), Krupka (2007), }\end{array}$ & $\begin{array}{l}\text { Attractive local environment } \\
\text { Tolerant atmosphere }\end{array}$ & $\begin{array}{l}\text { Cultural activities for } \\
\text { international skilled workers } \\
\text { Promoting cultural diversity } \\
\text { and tolerance }\end{array}$ \\
\hline $\begin{array}{l}\text { Migrant self-selection } \\
\text { Borjas (1987) }\end{array}$ & Progressive return to skills & $\begin{array}{l}\text { Tax reduction for highly } \\
\text { skilled migrants }\end{array}$ \\
\hline $\begin{array}{l}\text { Structural theories } \\
\text { Fawcett (1989), Kritz and } \\
\text { Zlotnik (1992), Frank (1966), } \\
\text { Wallerstein (1974) }\end{array}$ & $\begin{array}{l}\text { Historical, cultural, colonial } \\
\text { and technological linkages } \\
\text { between countries }\end{array}$ & $\begin{array}{l}\text { Fostering networks of the } \\
\text { highly skilled } \\
\text { Promoting cross-country ties } \\
\text { (bilateral agreements) } \\
\text { Internationalization of } \\
\text { education system }\end{array}$ \\
\hline
\end{tabular}




\section{Highly-Skilled Migration to the EU and the US: The Legal Framework ${ }^{8}$}

\subsection{Introduction}

In the international competition for highly-skilled labour, many industrialised countries are changing their policies in order to become more "attractive" to highlyskilled migrants. The "traditional immigration countries" (Australia, Canada and the United States) have long offered flexible admission criteria and attractive residence rights to highly-skilled migrants. European countries, on the contrary, have been reluctant to give up their "zero-migration" policies of the past. However, European countries have become increasingly involved in changing their labour migration policies in order to attract highly-skilled migrants from third-countries. In recent years European companies have faced an increasing lack of qualified labour in the highly skilled sector. Shortages are particularly notable in specific sectors, such as engineering, information technology, pharmaceuticals, healthcare and education. In the coming years, labour and skills shortages are predicted to rise even further, resulting in high employment growth for highly skilled workers (Frattini, 2007). A rising highly skilled labour supply resulting from immigration of third country nationals and an effective management of economic migration can play an important role in meeting such labour shortages and stimulating productivity growth. It is beyond doubt that so-called "replacement migration" cannot be the sole option to deal with shrinking labour forces and an ageing population. Labour immigration can only be part of a "policy mix" addressing these problems, next to labour migration policies, higher retirement ages, higher labour force participation rates of women and migrants and active family policies. Be that as it may, there is a growing recognition for the need of the EU and its Member States to implement more attractive migration policies for highly qualified immigrants. Europe has thus emerged as a new player in the "global competition for talent", competing with traditional countries of immigration for the brightest migrants (Papademetriou, 2003b).

\footnotetext{
${ }^{8}$ Some ideas in this chapter were also reflected in an earlier piece of writing with Dr. Anja Wiesbrock: Making Europe More Attractive to Indian Highly-skilled Migrants? The Blue card directive and national law in Germany and the Netherlands, CARIM-India Research Report; 2012/09.

And: Hercog, M., \& Wiesbrock, A. (2009). The Legal Framework for Highly-Skilled Migration to the EU: EU and US Labour Migration Policies Compared. In J. Wouters \& S. Sterkx (Eds.), European Union, United States and Global Governance - Major Trends and Challenges (pp. 127-145). Brussels: Leuven Center for Global Governance Studies.
} 
In recent years, a growing number of European countries have introduced national migration policies specifically targeted at highly-skilled migrants. National admission schemes were supplemented in May 2009 by the adoption of a Community instrument for the admission of highly qualified labour: Directive 2009/50/EC. In spite of such efforts, the number of migrants entering and residing in the Member States under such policies has been lower than expected. The number of highly-skilled migrants coming to the EU is still relatively low, especially in comparison with traditional immigration countries. The United States, in particular, attracts a considerably higher share of internationally mobile skilled labour force than the EU as a whole (Boeri, 2008).

Despite the potentially significant societal and labour market implications of highlyskilled migration policies in Europe, the new dynamics have been subject to only a few inquisitive studies in the academic literature (Avato, 2009; Boeri, Brücker, Docquier, \& Rapaport, 2012; Geis, Uebelmesser, \& Werding, 2008b; Laudel, 2005; Shachar, 2006; Zaletel, 2006). This chapter seeks to close this gap by comparing the existing legal framework on highly-skilled migration in three EU Member States, namely the United Kingdom, the Netherlands and Germany, and their main competitor country in the international competition for highly-skilled labour force, the United States. The three EU Member States were selected for this chapter because of their relative importance for skilled migration within the EU and because of their targeted migration policies. We look at a set of immigration policy dimensions, and assess the 'attractiveness' of national rules for potential highlyskilled migrants. The comparative analysis addresses the question whether it is still justified to consider Europe as restrictive in this respect.

We start by introducing the theoretical framework for the analysis of immigration policies. Based on the existing body of literature, we develop a set of comparative criteria by which national policies are assessed. For each of the five criteria chosen, we explain why they are considered relevant and in what way they play a role in affecting the attractiveness of the legislation. The subsequent section describes the national context for the four case studies by each of the specified criteria. Next, the chapter compares and evaluates the chosen immigration rules on the basis of the five selected criteria. In addition, we consider in what way the implementation of the EU Blue Card Directive can be expected to raise the attractiveness of the EU for highly-skilled migrants. The last section concludes by summarizing the findings.

\subsection{Theoretical Framework}

This chapter builds on two strands of literature. Besides adding to the debate on comparison of immigration policies, this chapter also contributes to the 
convergence/divergence debate. The "convergence hypothesis" (Cornelius et al., 1994) proposes that the industrialised labour-importing countries are becoming increasingly similar in terms of policy instruments, efficacy and public reactions to immigration. Sassen (1998) further argues that state authority is decreasing due to the increasing effect of economic globalization, taking effect on immigration policies through the growing role of supranational organizations and the transnational legal regime for cross-border business transaction. On the contrary, Shachar (2006) does not see nations losing control over their own immigration policies. The competitive recruitment environment leads to an even more active role of immigration agencies. According to her, national immigration policies are no longer insulated from actions of other countries. Instead, they are part of a multilevel game where countries are learning from and emulating each other. The policy convergence of competitive immigration regimes is, thus, also a product of interjurisdictional competition. Our chapter explores whether, in a situation where many countries have the same policy goal of attracting and retaining the skilled labour force, we can actually observe convergence of immigration policies.

While the convergence literature focuses primarily on the reasons for policy changes, our chapter comes closer to the second strand of literature, which instead uses comparative methodology to analyse the differences and similarities between migration schemes. Several studies have identified the criteria for comparison of immigration policies. McLaughlan and Salt (2002) compare thirty-one schemes towards highly-skilled workers in ten countries. Policies in each of the countries are described according to four broad categories of criteria: permits, application procedures, marketing of a particular scheme, and collection of statistics. The article provides rich information for each of the described schemes, but leaves out the analytical comparison across policies and across countries. Lindsay Lowell (2005) corrects for that and contributes to the comparative immigration policy debate by constructing an index, which ranks twelve countries according to seven criteria $^{9}$ in order to place them on a scale from controlled to competitive programmes. Due to the rapid changes in immigration laws, the rankings are subject to constant changes. The index ranks policies in 2004, which is before major policy changes took place in several countries under observation. With the intention of showing that the legislation and policies on highly-skilled migration differ considerably among countries, Cerna (2008) updated and expanded Lindsay Lowell's index to a larger group of countries. She observes twenty-four different temporary programmes for highly-skilled migrants in terms of admission

\footnotetext{
${ }^{9}$ The seven comparative criteria used by Lowell are the following: numerical caps, labour market test, labour protections, enforcement mechanisms, employer portability, restriction on dependents / working spouse, and permanency rights.
} 
mechanisms and employment rights. Christian's (2000) chapter adds to the debate by pointing to regulatory mechanisms not only at the nation-state level but also at the multilateral and regional level. His paper compares advanced industrial countries in terms of class of admission, the use of quotas, requirements and procedures before and following entry, and terms applying to time limits, transition to permanent residence, limits on employer, and family reunification options.

Zaletel (2006) differs from the above mentioned papers since it compares the temporary migration schemes for the highly skilled only for three countries: the United States, Germany and the UK. It looks at the eligibility criteria, benefits for the employee and requirements for the employer. The major divergence between the schemes is found in the limited period of residence allowed by the German Green Card. Two other factors, highlighted as important determinants of the scheme's attractiveness, are the right to family unification and the flexibility in terms of looking for other employers in the country. Shachar (2006) compares a number of traditional and new migration countries and contributes to the debate on the competition for skilled migrants by emphasizing one aspect of immigration policy; that is the citizenship factor. According to the citizenship theory, individual knowledge migrants select the destination country most suitable to them in terms of economic as well as citizenship rewards. The economic advantage of the United States is challenged by the innovative ways of other traditional and new migration countries to attract skilled workers.

It is noticeable that previous papers in the field of comparative migration policies either opt for a detailed account of only a few case-studies or for a systematic comparison of a number of policies by clearly specified criteria. In the above mentioned papers, one of these two qualities is chosen at the expense of the other. Our chapter aims to overcome this divide and combine the attributes of both approaches. It provides a clear disaggregation of policies into sub-categories as well as a detailed description of immigration policies. In comparison to the comparative studies mentioned above, we come closer to the approach of Zaletel's work (2006) and purposely choose a limited number of cases, in order to allow for an in-depth evaluation of national policies. Moreover, we build on the comparative papers (Cerna, 2008, 2013; Laudel, 2005; Lowell, 2005) and select a clear list of criteria by which we disaggregate policies on the terms attached.

The comparison of migration policies for this chapter is done by looking at five different aspects of policies, which we consider to be relevant in migrants' decision to move to a particular country. The observed dimensions are: 1) eligibility criteria, 2) special provisions for young migrants and options for transition to the labour market for former students, 3) validity of permits and access to permanent 
residence, 4) family migration options and 5) employment rights and social security provisions. The selection of the chosen categories follows the previously discussed literature as well the elements of immigration policies.

A specific goal of this chapter is to assess the relative attractiveness of migration policies of the three chosen EU Member states as compared to the United States. The three EU Member States were selected, firstly, because of their relative importance for highly skilled migration from third countries and, secondly, because of their targeted migration policies. All three countries have recently introduced or amended their labour migration policies in order to attract highly skilled migrants from third countries. Acknowledging the different levels of regulatory mechanisms (Christian, 2000), we extend the comparison at the nation-state level to include the contribution of the EU Blue Card Directive to the attractiveness of the concerned Member States and to the EU as a whole. The next section examines each of the chosen criteria and explains why they were selected as the indicators of attractive highly-skilled immigration policies.

\subsection{Comparative Criteria for Immigration Policies}

The selection of criteria for our analysis is based on different theoretical approaches on determinants for migration (Hercog, 2008) as well as on the overview of earlier comparative studies in this field. When choosing a country of destination, potential highly-skilled migrants are influenced by a huge variety of factors, including migration policies, wages, tax regimes and the political environment in the host country as well as already existing migration networks (Beine et al., 2009; Belot \& Hatton, 2008; Grogger \& Hanson, 2008). In this chapter we will focus on the first factor, namely the potential of highly-skilled migration policies in countries of destination to influence migration choices.

We assess the policy as successful when the immigration process is made easier from the perspective of a potential migrant. In our comparative evaluation, each element of policy is considered to be closer to best practice when it facilitates the entrance and stay of migrants. Although we acknowledge that immigration policies have various other objectives, this chapter looks solely at the goal of making policies more welcoming for foreign workers. The comparison of immigration policies is concerned with the legal framework of immigration policies and not with enforcement mechanisms. It is important to note this, since the gap between policy goals and outcomes can be partly attributed to problems regarding policy implementation. However, the focus of the chapter is on the legislative framework and does not delve into evaluating policy implementation. 
One of the crucial aspects determining the attractiveness of host countries for highly-skilled migrants is the definition of who constitutes a highly-skilled migrant and the nature of eligibility requirements. As there is no agreed international definition of "highly-skilled workers", the use of the concept varies amongst countries and is closely linked to national eligibility requirements (OECD, 2002). Receiving states generally use a person's level of education and/or occupation in order to determine whether he/she falls within the category of "highly-skilled migrant" (IOM, 2008). The more open these criteria are for skilled migrants, the more attractive we consider that country's policy. This same category was captured by the above mentioned comparative papers in both the classification of admissions and in the sub-category on quotas. Among the observed countries, the United States as well as the United Kingdom limit the inflows of skilled migrants by an imposed annual quota. However, we do not include it as a separate sub-category but instead consider the use of a quota as a limiting factor for the attractiveness of eligibility criteria.

Secondly, we look at whether immigration policies give special provisions for making entry for younger migrants more accessible. In comparison with other categories of highly-skilled workers, young professionals and students educated in the host state hold a great potential to be active in the labour market for a long period. Younger, educated people are the most likely to migrate because of the longer period they will be able to reap the returns of the migration decision. At the same time, young highly-skilled migrants at the beginning of their career often lack the required work experience and salary level to be admitted under the "ordinary" highly-skilled migrant programmes. An additional advantage of foreign students transitioning to host country's labour market as highly-skilled workers is that they have already proven themselves in the host country's education system. Consequently, several countries have adopted special rules applicable to young migrants and in particular to former students, allowing them to benefit from less demanding entry requirements. It is a relatively new feature of immigration policies, which might be one of the reasons why special provisions for young migrants have not been included in the comparative studies so far. Inclusion of this sub-category substantially improves the framework for comparing immigration policies since it better captures recent developments in the policy area. Considering the fact that migrants are concentrated in the younger age groups and that foreign graduates demonstrate high stay rates after the graduation in OECD countries (OECD, 2007), our chapter corrects for the omission of an important aspect of immigration policies. 
The third policy dimension that we observe are the rules concerning the validity of the residence permit offered to highly-skilled third-country nationals. The opportunity to acquire a stable and secure residence status as well as access to permanent residence rights after a certain period of time have become a valuable good that countries can offer to highly-skilled workers in exchange for their skills and knowledge (Shachar, 2006). The failure of the German Green Card to attract the expected number of highly-skilled migrants is often attributed to the terms applying to the period of residence, since this scheme did not allow for the possibility of permanent residence in Germany (Zaletel, 2006). Examples of studies on skilled temporary migrants in Australia (Khoo, Hugo, \& McDonald, 2008) and on Slovakian return and potential skilled migrants (Balaz, Williams, \& Kollar, 2004) confirm the strong link between temporary and permanent migration. In general, both studies show that many migrants, especially those coming from developing countries (Khoo et al., 2008), would like to become permanent residents. Moreover, many respondents in the Australian case study indicate the option of permanent residence as an important reason for initial migration. At the same time, temporary migration facilitates permanent migration; many people who initially came only for the purpose of international exposure later change their initial plans and want to apply for permanent residence. There are numerous reasons why people want to become permanent residents. The significance of this option for prospective migrants has been accepted by the earlier literature (Cerna, 2008; Christian, 2000; Lowell, 2005; McLaughlan \& Salt, 2002; Zaletel, 2006), which gives the edge in terms of attractiveness to countries with easier access to long-term residence. The maximum allowed duration of residence and conditions for access to a permanent residence status are therefore important in determining the attractiveness of national highly-skilled migrant programmes.

A further crucial factor influencing highly-skilled migrants' decisions concerns policies regarding accompanying family members. Also the rights granted to family members upon arrival can play a decisive role in their decision-making process (Guth, 2007; Koser \& Salt, 1997; Liebig, 2003; Smith, 2004). Research has shown that job relocation is a stressful event for employees (Anderson \& Stark, 1985) and even more for "trailing spouses" (Harvey, 1997; Martin, 1996). Highly-skilled workers usually have partners who are also interested in their own careers. Greenbury and Shortland list the following problems that a spouse could face: work permit restrictions, lack of job opportunities abroad, language and cultural differences, lost promotional opportunities, lack of transferable skills, and financial implications (Koser \& Salt, 1997). Offering the principal migrant's spouse a possibility to work in the host country is an important factor in the decision to move of dual-career couples, which are very common among highly-skilled workers. 
Highly skilled third-country nationals are likely to inform themselves about employment rights and social security provisions in their future country of residence, which is used as the fifth criteria for the comparative analysis. Providing prospects for professional development is an important aspect for career-oriented migrants. Enabling foreign workers to switch jobs without facing huge administrative burdens increases their opportunities to meet their career aspirations. Especially for people from developing countries, international migration offers a means to overcome missing or failed markets for capital, credit, and insurance (Stark, 1991). When receiving countries' conditions are to some extent independent of economic conditions in the sending country, migration is considered as insurance against deterioration. Welfare-state benefits are found to have positive effects on the concentration of skilled and low-skilled workers (De Giorgi \& Pellizzari, 2006; Docquier et al., 2006). For those highly-skilled people that migrate due to a risk-diversifying strategy, a country will, hence, become more attractive when it provides more security for migrants and their families.

The following section observes each of these elements in American, British, German and Dutch immigration policies for the highly skilled and draws transparent tables at the end of each section which enable clear comparison of policies in the chosen parameters. Although other channels of entry for the highly skilled exist in all the observed countries, the focus in this article is on policies envisaged as special programmes to attract highly-skilled migrants.

\subsection{Comparing Highly-Skilled Migration Policies in the United States and the EU}

\subsubsection{The Definition of the 'Highly Skilled' and Eligibility Requirements}

The United States Immigration and Nationality Act provides several ways for foreign nationals to come and live in the United States on a temporary basis (holding non-immigrant visas). In this analysis we focus on provisions with respect to $H-1 B$ visas, which specifically apply to persons in a specialty occupation (as defined in section 214 (i) (1) of the Act). A further reason for focusing on H-1B programme is also the dominance of its use among skilled workers as compared to other programmes. Intra-company transferee visa programme (L-1 visa) is the second most utilized programme but in that case migrants themselves have less of an influence on where they will move for work rendering the attractiveness of policies less relevant for a potential skilled migrant. A discussion of all the different entry categories is beyond the scope of this chapter. For an immigrant to be eligible for $\mathrm{H}-1 \mathrm{~B}$ visa in the United States he/she must demonstrate that he/she is able to 
work in the specialty occupation for which he/she is being hired by the sponsoring employer (Immigration and Nationality Act section 101(a)(15)(H) (i) (b)). This can be demonstrated in a number of ways. The applicant should have at least a four year US bachelor's degree or its foreign equivalent. However, requisite experience can substitute for education, as three years of progressive work experience can substitute the fourth year of the US bachelors' degree. In addition, particular specialty occupations require State or a Federal license in order to practice that occupation. An additional requirement for obtaining $\mathrm{H}-1 \mathrm{~B}$ visa is that the prospective employer has to pay a salary equivalent to US employees engaged in a comparable position in the same field. ${ }^{10}$

The British government introduced a so-called Points-Based immigration system with five different tiers in 2008 (House of Commons, 2008). Highly-skilled migrants may enter the UK under Tier 1, which is explicitly targeted at "high-value migrants", or under Tier 2 on the basis of a fixed work contract for "skilled migrants". Since April 2011 significant changes have been introduced in the UK immigration law, including tightened eligibility rules and substantial cuts in the annual cap figures. The Tier 1 (General) category is closed and replaced by a three-part Tier 1 program for exceptional talent, entrepreneurs and investors. As the name suggests, the Exceptional Talent route is meant for individuals who are internationally recognized at the highest level as (potential) world leaders in their field. The UK government has limited the number of applications for Exceptional Talent to 1000 places per year, which makes this route highly restricted. Previously, if you were granted leave for the general Tier 1 category under the point-based system attributing points for qualifications, previous earnings, age, UK work experience and English language skills, you could stay in the UK without first having an employment contract. Following the tightened regulations, the main path for skilled workers to the UK is applying under Tier 2 . In order to be granted leave to enter under Tier 2 (General), applicants must have a job offer from a licensed sponsor. Applicants must receive 50 points for their attributes, which includes having a sponsor and a valid Certificate of Sponsorship (Appendix A of the Immigration Rules) as well as 10 points for English language skills (Appendix B of the Immigration Rules) and 10 points for available maintenance funds (Appendix C of Immigration Rules). In addition, the job offered has to be at NQF level 4 or on the list of shortage occupations. The sponsor has to confirm the applicant will be paid a minimum of $£ 35,000$ or the appropriate level for the specific job. There is an annual limit on the number of Certificates of Sponsorship available under Tier 2 (General), which applies to jobs that have a

\footnotetext{
10 8CFR 214.2 (h) (4)(iii)
} 
salary of less than $£ 150,000$ per annum (Home Office-UK Border Agency, Tier 2 Version 4/2012).

In Germany, the rules on highly-skilled migrants were introduced with the enactment of the 2005 Residence Act (Aufenthaltsgesetz, AufenthG). Section 19 of the Residence Act provides for the admission of "highly qualified" workers even though it does not contain a general definition of who is considered to be "highly qualified". Three different categories of persons generally fall under the regime for highly qualified immigrants. The first category includes scientists and academics with outstanding qualifications. The second category refers to teaching personnel in high-rank positions (that is, tenured professors or academics who are leading scientific projects or research groups). Beyond the provisions of the EU Blue Card, these categories remain to be regarded as highly qualified and there is no income requirement imposed. Under category three, specialists and executive personnel were considered to be highly qualified if they had adequate professional experience and a certain annual minimum income (gross income of at least the income threshold for general pension insurance $(€ 67,200$ in 2012)). The Act to Implement the EU Blue Card Directive repealed the last part and lowered the annual minimum income threshold for entry. Since 1 August 2012, when the Residence Act was amended following the implementation of the Blue Card Directive, highly qualified third-country nationals are defined as those with a recognised university degree and having an annual income that corresponds to at least two-thirds of the annual income threshold for the general pension insurance ( $€ 47,600$ in 2014). For the occupations with a particular need for qualified labour the annual minimum salary is lowered to half of the earnings ceiling of the general pension insurance system $(€ 37,128)$. Such occupations with a special need for highly skilled workers include science and engineering professionals, medical doctors and information and communications technology professionals. The amendments to the Employment Ordinance, taking effect in 1 July 2013, opened the German labour market for the first time also for third-country nationals who have completed at least two years professional education (Section 6 Employment Ordinance Amended). Following these changes skilled workers now include highly qualified and qualified workers, as both are the focus on the Federal Government's strategy for employment immigration. Qualified workers may come to work in one of the shortage occupations or through bilateral placement agreements with countries of origin (Mayer, 2013, p. 17). In respect to the mentioned categories, a prior approval of the Federal Labour Agency is not necessary for the granting of a settlement permit (Section 3 Employment Ordinance). In addition to being considered a highly qualified worker, there must be a specific job offer (Section 18(5) Residence Act). Second, there must be reasons to assume that the immigrant 
will become well integrated into German society. This requirement is, however, mitigated by the fact that highly qualified workers (and their family members) are not obliged to pass a German language test prior to entry. Third, the immigrant must demonstrate that he can sustain himself without relying on state resources (Section 19(1) Residence Act). Finally, the entry of the person concerned must constitute a "special case" ("in besonderen Fällen") in the sense of paragraph 1 of Section 19 AufenthG. Since 1 April 2012, with the enforcement of the Federal Law on Recognition of Foreign Qualifications ${ }^{11}$, third country nationals also got access to have their foreign qualifications assessed and recognized as equivalent to German qualifications, which was previously only possible for those with European professional and vocational qualifications. In case of a negative assessment, compensation measures such as training, aptitude or theoretical tests may still enable recognition (Section 11 (1) of BQFG). This measure significantly improves the options of foreign skilled workers to use their qualification on the German labour market.

The Netherlands introduced a Knowledge Migrant Scheme (Kennismigrantenregeling) targeted at highly-skilled migrants in October 2004. The criteria to assess whether a person qualifies as a knowledge migrant are exclusively based on the salary offered to the prospective migrant. Knowledge migrants are defined as immigrants who have been offered a position by an eligible employer and are set to receive a certain minimum income as stipulated by the Minister of Social Affairs and Employment on an annual basis. The prospective employer must have signed an agreement with the Immigration and Naturalization Service (IND) in order to become eligible for the accelerated procedure under the Knowledge Migrant Scheme. For 2013, the minimum annual gross salary for knowledge migrants was stipulated at $€ 52,010$ for employees 30 years of age or older, and $€$ 38,141 for employees below 30 years of age. As of 1 January 2014 the amount is specified per month instead of annually. Now, a contractually fixed gross salary must be at least $€ 4.371,84$ per month for migrants older than 30 years and $€ 3.205,44$ for those younger than 30 0(IND, 2012, 2014; Ministry of Social Affairs and Employment, 2009). Since November 2006, an exception to the salary criterion is made for scientific researchers and foreign doctors completing their studies in the Netherlands to become a specialist. On 1 January 2012 a pilot scheme for short residence as knowledge migrant entered into force. ${ }^{12}$ The pilot schemes ran for two years until 30 December 2013 and was changed into a permanent scheme as of

\footnotetext{
${ }^{11}$ Berufsqualifikationsfeststellungsgesetz (BQFG)

12 Paragraph 19 of the Implementing Regulation Foreign Nationals Employment Act (Uitvoeringsregels Wet arbeid vreemdelingen) see also Regeling van de Minister van Sociale Zaken en Werkgelegenheid van 21 november 2011, nr. AV/SDA/11/8324.
} 
beginning of 2014. Under the scheme, employers registered with the IND may employ knowledge migrants for a short period of up to three months. For such migrants, the admission procedure is faster and less bureaucratic. There is for instance no labour market test and foreign workers do not have to provide their CV and diploma to be admitted. The same salary threshold as for other knowledge migrants applies. In addition, highly skilled workers can be admitted under the Dutch implementing rules of the EU Blue Card. The conditions for admission as a Blue Card holder are more difficult to fulfil than those applicable under the knowledge migrant scheme. Highly skilled workers must have an employment contract or binding job offer for a period of at least one year and with a gross minimum salary of at least $€ 5,122$ per month. ${ }^{13}$ Moreover, as opposed to the knowledge migrant scheme, applicants for an EU Blue Card must demonstrate that they have successfully completed a University degree of at least three years in the Netherlands or in a comparable institution abroad. ${ }^{14}$ Table 3.1 summarizes the eligibility criteria for the four observed countries looking at the requested criteria to be fulfilled by migrants.

Table 3.1: Eligibility criteria

\begin{tabular}{|c|c|c|c|c|}
\hline & United States & United Kingdom & Netherlands & Germany \\
\hline Minimum Salary & $\begin{array}{l}\text { Equivalent to a } \\
\text { comparable US } \\
\text { employee }\end{array}$ & $\begin{array}{l}f 35,000 \text { or the } \\
\text { appropriate level } \\
\text { for the specific job }\end{array}$ & $\begin{array}{l}€ 4,371 \text { (aged } \\
30+\text { ), €3,205 } \\
\text { (aged }<30 \text { ) } \\
\text { monthly }\end{array}$ & $\begin{array}{l}€ 47,600 \text { and } \\
€ 37,128 \text { for } \\
\text { shortage } \\
\text { occupations }\end{array}$ \\
\hline $\begin{array}{l}\text { Required level of } \\
\text { qualifications }\end{array}$ & $\begin{array}{l}\text { 4-years BA, or 3- } \\
\text { years BA + work } \\
\text { experience }\end{array}$ & NQF 4 & No & $\begin{array}{l}\text { University } \\
\text { degree }\end{array}$ \\
\hline $\begin{array}{l}\text { Required work } \\
\text { experience }\end{array}$ & $\begin{array}{l}3 \text { y. substitute } \\
\text { one year of } \\
\text { studies }\end{array}$ & No & No & Yes \\
\hline $\begin{array}{l}\text { Required } \\
\text { employment contract }\end{array}$ & Yes & Yes & Yes & Yes \\
\hline Language test & No & Level C1 of CEFR & No & No \\
\hline Integration test & No & No & No & No \\
\hline $\begin{array}{l}\text { Maintenance } \\
\text { obligation }\end{array}$ & Yes & Min. $£ 900$ & Yes & Yes \\
\hline $\begin{array}{l}\text { Special rules for } \\
\text { scholars/researchers }\end{array}$ & $\begin{array}{l}\text { J-1 visa for } \\
\text { researchers, } \\
\text { professors, } \\
\text { interns }\end{array}$ & $\begin{array}{l}\text { No salary } \\
\text { threshold for } \\
\text { scientists and } \\
\text { researchers in } \\
\text { PhD-level roles }\end{array}$ & $\begin{array}{l}\text { No salary } \\
\text { threshold for } \\
\text { researcher, } \\
\text { lecturers }\end{array}$ & $\begin{array}{l}\text { No salary } \\
\text { threshold for } \\
\text { highly qualified } \\
\text { academics/ } \\
\text { lecturers }\end{array}$ \\
\hline
\end{tabular}

${ }^{13}$ Article 3.30b Aliens Decree (Vreemdelingenbes/uit) jo. 1i(a) Decree implementing the Law on the Employment of Foreign Nationals (Besluit uivoering Wet arbeid vreemdelingen).

${ }^{14}$ Article $1 \mathrm{i}(\mathrm{b})$ Decree implementing the Law on the Employment of Foreign Nationals. 


\subsubsection{Special Provisions for Young Migrants and Former Students}

In the United States, the option to stay for up to one year and receive practical training has been given to foreign graduates of US universities for a long time (Konrad, Roads, \& Norman, 1997). This OPT (Optional Practical Training) is open to F-1 visa holders ${ }^{15}$ and currently about 70.000 students take part in it. They work in their specific field of studies and get a chance to gain valuable experience in preparation for the job market. Graduates in the fields of Science, Technology, Engineering or Mathematics (STEM) can now be granted a longer extension of up to 17 months. ${ }^{16}$ All OPT participants may later have the option to change their status to become a regular labour migrant (USCIS, 2009). In January 2012 the Department of Homeland Security announced changes which would expand the eligibility of 17-months extension of OPT by including students with a STEM degree that is not the most recent degree the student has received (DHS, 2012). Overseas graduates from post-secondary US institutions may take up employment in the United States on a temporary basis with a H-1B visa. The H-1B Visa Reform Act of 2004 made special provisions for foreign workers with a Master's or higher level degree from a U.S. academic institution (Advanced Degree Exemption). For each fiscal year, 20.000 beneficiaries of $\mathrm{H}-1 \mathrm{~B}$ petitions on behalf of persons who hold such credentials are statutorily exempted from the cap (USCIS, 2009). ${ }^{17}$ Employers filing a petition have to pass a labour attestation proving that they could not find a national for the position in the same way as for other immigrants.

In the United Kingdom, young professionals are no longer in a favourable position to reach the necessary points under Tier 1 or Tier 2 of the new points-based system. Before the changes in 2011, youth (defined as those under 32 years) were awarded additional points. In addition, the Tier 1 (Post-study work) category, which allowed the UK to retain the most able international (non-European) graduates who have studied in the UK, ceased to exist in April 2012. Also the International Graduates Scheme (IGS) is now closed to new applicants. It was introduced in May 2007, allowing non-EEA graduates with a bachelor's degree in any discipline from a recognized institution in the UK to remain in the country for 12 months to work

\footnotetext{
${ }^{15} \mathrm{~F}-1$ visa is a non-migrant student visa which allows foreigners to study in the United States.

168 CFR 214.2 (f) (10) (ii)

${ }^{17}$ Annually, there is a limit of visas given out to the $\mathrm{H}-1 \mathrm{~B}$ category. Since the fiscal year 2004 the maximum has been set at $65.000 \mathrm{H}-1 \mathrm{~B}$ visas per year. The Twenty-First Century Act of 2000 (Public Law 106-313) exempted workers at non-profit and governmental research organization and institutes of higher education from numerical limit. In addition, the H-1B Visa Reform Act of 2004 (Public Law 108-447) introduced additional 20,000 visas for those who earned a Master's or a higher degree at a US university, which makes the actual number of visas issued annually above 100,000. In fiscal year 2009, there were $105,775 \mathrm{H}-1 \mathrm{~B}$ visas issued for initial employment (USCIS, 2010).
} 
after their studies. It is now possible to switch from a student category (Tier 4) to Tier 2 if the applicant has successfully completed and passed a UK recognised bachelor or postgraduate degree ${ }^{18}$ at a UK institution and is applying from within the UK. The sponsor will then be exempt from undertaking a resident labour market test (Home Office-UK Border Agency, Tier 2 Version 4/2012).

In principle, the German Residence Act does not distinguish between older and younger highly-skilled workers. This has been widely criticized, as the tough entry conditions and high income ceiling of the initial version of the reformed Residence Act made it extremely difficult for young professionals to enter the German labour market (Bundesministerium des Inneren, 2006). Section 19 AufenthG is clearly more directed to experienced scientific personnel (such as executive staff or executive managers) rather than graduates and young professionals who stand at the beginning of their career, however the salary criterion was significantly reduced with the enactment of the EU Highly Qualified Directive in 2012. Moreover, Section 16(4) Aufenth $\mathrm{g}$ makes it possible for foreign students who have successfully completed their studies in Germany to obtain an extension of their residence permit to search for a job. The period for job searching was also further extended from 12 to 18 months in 2012 (Section 16(4) AufenthG). The amendments to the Residence Act also allow foreign graduates to take up employment during this period of time. ${ }^{19}$ During the past years options for working during studies have significantly expanded from 90 to 120 full days or 240 half-days within a year (Section 16(3) AufenthG). In addition, foreigners holding a German university degree do not require approval from the Federal Employment Agency for acquiring a residence permit - i.e. review of whether filling the position would be a responsible decision from a labour market and integration policy perspective neither do they require a labour market test as long as they receive the minimum income. Furthermore, graduates of German Universities may be granted a settlement permit after having been employed at their skill level in Germany for a period of two years. ${ }^{20}$ Since 2012 it is also possible to come to Germany without a prior job offer as residence permit may be given for six months permit to people with a recognised university degree with secured subsistence. ${ }^{21}$

The Dutch Knowledge Migrant Scheme takes into account that it is more difficult for younger migrants to reach the designated salary threshold. The required salary

\footnotetext{
18 The same applies also for completing a UK Postgraduate Certificate in Education (PGCE) or Professional Graduate Diploma of Education (PGDE); or if an applicant has completed a minimum of 12 months study in the UK towards a UK PhD.

${ }^{19}$ Section 16(4) of the Residence Act.

${ }^{20}$ Section 18b of the Residence Act.

${ }^{21}$ Section $18 c$ of the Residence Act.
} 
level is adjusted for people below 30 years of age, which makes it possible for younger people who are just starting their careers to reach the criterion. ${ }^{22}$ For 2014, the lowered threshold for the minimum monthly gross salary is $€ 3,205$ as compared to $€ 4,371$ for employees older than 30 years. An additional attribute of the Dutch migration policy is the job-search period after completion of studies at a university in the Netherlands. ${ }^{23}$ Foreign students have one full year to look for positions as highly-skilled migrants after the completion of their studies in the Netherlands. Moreover, a different salary criterion applies to former students who find work at their education level immediately after the completion of studies. For 2014, the minimum starting salary for students, using a one-year job-search period, is stipulated at $€ 2,297$ monthly. The lowered salary criterion corresponds better to the actual salary levels of beginners on the labour market. Moreover, in January 2009, the Netherlands introduced a new Admission Scheme for Highly Educated Migrants which allows recent graduates to get an authorisation for temporary stay even without a job-offer. ${ }^{24} \mathrm{~A}$ person who has completed a master's degree or a doctorate from a Dutch university or from a non-Dutch institution of higher education which ranks among the top 200 universities on the Times Higher Education list, QS World University Ranking or the Academic Ranking of World Universities can within three years after graduation ask for a one-year residence permit and look for employment in the Netherlands without a prior job-offer. In addition to the academic-degree requirement, foreign nationals are assessed on the basis of a point system, which awards points with regard to age, level of education and other performance indicators in the Netherlands. ${ }^{25}$ Table 3.2 compares the four observed countries with regard to giving preferable access to younger educated migrants.

\footnotetext{
${ }^{22}$ Article $1 \mathrm{~d}(1)(\mathrm{a})$ no $1^{\circ}$ Decree implementing the Law on the Employment of Foreign Nationals

${ }^{23}$ Article 1d (1) (a) no. 2 Decree implementing the Law on the Employment of Foreign Nationals.

${ }^{24}$ Besluit van de Staatssecretaris van Justitie van 12 december 2008, 2008/30.

${ }^{25}$ The minimum required number of points is 35 (out of 40 as a maximum). If a student graduated or achieved a doctoral degree from a Dutch institution for higher education or at a top level foreign university, a maximum number of 30 points can be achieved. Additional 5 points are awarded for applicants in the age group from 21 to 40. If the applicant previously worked or studied in the Netherlands, knows Dutch or English language or has completed education in a country that is a signatory of Bologna Declaration, the migrant can get additional points for fulfilling performance indicators.
} 
Table 3.2: Policies for young migrants and former students

\begin{tabular}{|c|c|c|c|c|}
\hline & United States & $\begin{array}{l}\text { United } \\
\text { Kingdom }\end{array}$ & Netherlands & Germany \\
\hline $\begin{array}{l}\text { Special provisions } \\
\text { for young migrants }\end{array}$ & $\begin{array}{l}\text { Equivalent to } \\
\text { comparable US } \\
\text { employee }\end{array}$ & N/a & $\begin{array}{l}\text { Lower salary } \\
\text { threshold if }<30 \\
\text { years }\end{array}$ & $\mathrm{N} / \mathrm{a}$ \\
\hline $\begin{array}{l}\text { Admission of } \\
\text { former students } \\
\text { from host state's } \\
\text { universities }\end{array}$ & $\begin{array}{l}\text { Special H-1B } \\
\text { visa quota }\end{array}$ & $\begin{array}{l}\text { No labour } \\
\text { market test }\end{array}$ & $\begin{array}{l}\text { Reduced minimum } \\
\text { salary threshold }\end{array}$ & $\begin{array}{l}\text { No income } \\
\text { requirement, no } \\
\text { labour market test }\end{array}$ \\
\hline $\begin{array}{l}\text { Admission of } \\
\text { former students } \\
\text { from foreign } \\
\text { universities }\end{array}$ & N/a & $\mathrm{N} / \mathrm{a}$ & $\begin{array}{l}\text { One-year permit for } \\
\text { students from } 200 \\
\text { top universities of } \\
\text { THE ranking list }\end{array}$ & $\begin{array}{l}\text { Six-months permit } \\
\text { for qualified skilled } \\
\text { workers seeking } \\
\text { employment }\end{array}$ \\
\hline $\begin{array}{l}\text { Job-searching } \\
\text { period for former } \\
\text { students }\end{array}$ & $\begin{array}{l}12-17 \text { months } \\
\text { practical } \\
\text { training }\end{array}$ & $\begin{array}{l}\text { Cancelled in } \\
\text { April } 2012\end{array}$ & 12 months & 18 months \\
\hline
\end{tabular}

\subsubsection{Validity of the Permit and Access to Permanent Residence}

In the United States, the $\mathrm{H}-1 \mathrm{~B}$ visa is valid for three years and can be extended for additional three years up to a total of six years (Immigration and Nationality Act 214(g)(4)). A further extension is possible if the application for a permanent residence is being processed. $\mathrm{H}-1 \mathrm{~B}$ visa holders are allowed to change employers, provided that the new employer sponsors another $\mathrm{H}-1 \mathrm{~B}$ visa. Unlike other nonimmigrant visas, $\mathrm{H}-1 \mathrm{~B}$ visa also allows for dual intent, which allows migrants to apply for permanent residence. In this way, $\mathrm{H}-1 \mathrm{~B}$ holders are implicitly encouraged to become permanent Green Card immigrants (Lowell, 2001). The Immigration and Nationality Act establishes two main channels through which an alien may obtain lawful permanent residence status in the United States: family reunification and employment. Within employment-based immigration, priority workers have first preference for obtaining permanent residence (U.S. Department of State, 2009). ${ }^{26}$ However, only about half of the permanent visas for employment-based immigration are given to workers as their dependents are counted against the cap and, hence, use half of the allocated 140,000 visas. Moreover, access to lawful permanent residency is constrained by immigration category caps and countryspecific caps, limiting each country to no more than 7 percent (approximately $25,600)$, which has created long delays for applicants from high-demand countries such as Mexico, China, India and the Philippines (Meissner et al., 2006).

\footnotetext{
${ }^{26}$ There are five different types of employment-based immigration which are classified in order of priority. Each priority category has an annual admission ceiling. Overall the Immigration and Nationality Act provides an annual minimum of 140,000 employment-based immigrant visas, out of which 28.6 percent plus the unused quote from other categories is reserved for priority workers (Meissner, Meyers, Papademetriou, \& Fix, 2006).
} 
In the United Kingdom, third-country nationals entering under Tier 2 will initially be granted three years leave. After expiry of this period, the skilled worker can be granted a subsequent grant of leave to remain for additional three years, beyond which it is not possible to extend it (Home Office-UK Border Agency, Tier 2 Version 4/2012). Recent changes in 2012 have also introduced a 'cooling-off period' for Tier 2, meaning that Tier 2 migrants need to wait for 12 months from the expiry of their previous visa before they may re-apply for a new Tier 2 visa (Statement of Changes in Immigration Rules HC 1888-March 2012). Skilled third-country nationals in Tier 2 are not permitted to change jobs within the UK. If they wish to change jobs and also if there is a significant change of duties with the same employer, they must make a new application for a new Certificate of Sponsorship which meets all the points' requirements. After continuous period of five years of lawful residence in the UK, skilled workers (Tier 2(General)) can obtain indefinite leave to remain (ILR) if the following requirements are fulfilled: The sponsor that issued the Certificate of Sponsorship for the applicant's last grant of leave must certify that he still requires the applicant for the employment in question, and that they are paid at least $£ 35,000$ per annum. There are exceptions to this for occupations on the Shortage Occupation List and for scientists and researchers in PhD-level roles. It is additionally required from Tier 2 migrants that they demonstrate they have sufficient knowledge of the English language and sufficient knowledge about life in the United Kingdom, unless the applicant is under the age of 18 or aged 65 or over at the time of the application (Immigration Rules 245HF).

Highly-skilled workers residing in Germany on the basis of Section 19 AufenthG have an unlimited right of residence in Germany from the outset. The permit is neither restricted in time nor in scope, allowing the worker to change his employment position as he wishes. Only a few professions are exempted, namely researchers with special technical knowledge and teaching or scientific personnel in high positions. Highly-skilled migrants admitted under the Blue Card EU are initially granted a residence permit with a validity of up to four years. If the employment contract is concluded for a period of less than four years, the Blue Card EU is granted for the duration of the employment contract plus three months. ${ }^{27}$ Holders of a Blue Card EU may acquire a settlement permit after a period of 33 months, provided that they have contributed to the pension system during this period of time. ${ }^{28}$ The required period is only 21 months if the resident speaks German at B1 level. After five years of residence in Germany in possession of a

\footnotetext{
${ }^{27}$ Section 19a(3) of the Residence Act.

${ }^{28}$ Section $19 \mathrm{a}(6)$ of the Residence Act.
} 
residence title, both types of highly-skilled migrants (admitted under Section 19 or the draft Section 19a) can acquire an EU long-term residence permit. ${ }^{29}$

The validity of the residence permit in the Netherlands depends on the type of employment contract. A migrant gets a residence permit for a period of the work permit if he/she holds a temporary work contract. When a knowledge migrant holds an employment contract for an indefinite period, a residence permit is granted for the duration of five years. ${ }^{30}$ The EU Blue Card is granted for a period equal to the duration of the employment contract plus three months. The maximum validity of the EU Blue Card is four years. ${ }^{31}$ The residence requirement to acquire EU long-term residence status is five years of uninterrupted legal residence for a non-temporary objective, such as employment or family reunification. Applicants for a long-term residence permit also have to fulfil certain material conditions. Sufficient and regular income to support his or her family is required. In addition, all non-EU/EEA immigrants have to pass an integration examination, which tests migrants for Dutch language skills and knowledge of Dutch society. ${ }^{32}$ Blue Card holders can acquire long-term residence status after a period of two years, provided that they have legally resided for at least five years in one of the EU Member States and have been in possession of an EU Blue Card in another Member State for at least 18 months before entering the Netherlands. Moreover, all other general requirements for acquiring long-term residence status have to be fulfilled.

Table 3.3: Permit validity and access to permanent residence

\begin{tabular}{|c|c|c|c|c|}
\hline & \begin{tabular}{|l|} 
United \\
States
\end{tabular} & United Kingdom & Netherlands & Germany \\
\hline $\begin{array}{l}\text { Initial validity of } \\
\text { the permit }\end{array}$ & 3 Years & 3 Years & Up to 5 years & $\begin{array}{l}\text { Permanent for highly } \\
\text { qualified specialist }\end{array}$ \\
\hline Possible extension & 3 Years & 3 Years & $\begin{array}{l}\text { Depending on } \\
\text { previous r.p. }\end{array}$ & $\mathrm{N} / \mathrm{a}$ \\
\hline \multicolumn{5}{|c|}{ Requirements for permanent residence } \\
\hline Residence & $\mathrm{N} / \mathrm{a}$ & 5 Years & 5 Years & $\mathrm{N} / \mathrm{a}$ \\
\hline Maintenance & No & $\begin{array}{l}\text { Sufficient income \& } \\
\text { No recourse to } \\
\text { public funds }\end{array}$ & $\begin{array}{l}\text { Sufficient \& } \\
\text { regular income }\end{array}$ & $\mathrm{N} / \mathrm{a}$ \\
\hline Language test & No & Yes & Yes & No \\
\hline Integration test & No & Yes & Yes & No \\
\hline
\end{tabular}

Foreign nationals admitted in the Highly Educated Migrants Scheme can either get a job as a knowledge migrant, otherwise employers will be required to have a work

\footnotetext{
${ }^{29}$ Section 9(2) No.1 Residence Act.

${ }^{30}$ Article 3.59a Aliens Decree.

${ }^{31}$ Article 3.59c Aliens Decree.

${ }^{32}$ Article 21, Aliens Act (Vreemdelingenwet 2000).
} 
permit. Table 3.3 compares the described countries according to initial validity of the permit, possibility for extension and requirements for permanent residence.

\subsubsection{Family Reunification Rights}

In the United States, the H-1B visa allows principal migrants to bring with them a spouse and unmarried minor children and they are admitted to the US in the H-4 category ("dependent of $\mathrm{H}$ visa holder"). ${ }^{33}$ The principal migrant has to show that he is able to financially support the dependents. Dependents are subject to the same period of admission and limitations as the principal migrant, however they are not allowed to work unless they qualify independently for a different visa which allows employment. ${ }^{34}$ Among the changes announced by the Department of Homeland Security are also the regulations which would authorize employment for certain $\mathrm{H}-4$ dependent spouses. The change would apply when the principal $\mathrm{H}-1 \mathrm{~B}$ visa holder has begun the process of seeking lawful permanent resident status through employment after meeting a minimum period of $\mathrm{H}-1 \mathrm{~B}$ status in the U.S. (DHS, 2012).

Dependents of third-country nationals who have obtained permission to enter the United Kingdom under Tier 2 (General) of the Points-Based System must make their own application for entry. If the application is successful, the leave will be granted in line with the expiry date of the main applicant's leave of stay (Home Office-UK Border Agency, PBS-Dependent Version 4/2012). A precondition for the entry of family members is that they must have $\mathrm{f600}$ per person to support themselves. This condition can be fulfilled by the dependent or the main applicant showing that they have at least $£ 600$ to support the dependant as well as the funds needed to support the main applicant. The alternative is that the main applicant provides a written undertaking that he/she will maintain and accommodate the family member for a month. Dependents of skilled workers are allowed to work in profession other than doctor or dentist in training (Immigration Rules 319D (b).

In Germany, family members of highly qualified workers within the meaning of Section 19 AufenthG are exempt from the requirement of proving a certain degree of German language proficiency before entry (Section 30(1) Residence Act), as long as the marriage already existed at the moment the highly qualified worker entered Germany and that the worker has shifted the central point of his life to Germany. The incoming family members of highly-skilled workers are automatically entitled to take up paid employment and can obtain an independent right to reside and work after marital cohabitation in Germany for at least two years. The same holds

\footnotetext{
${ }^{33}$ CFR 214.2 (h) (8) (E) (ii)(A)

${ }^{34}$ CFR 214.2 (h)(9) (Docquier et al., 2006)
} 
true for the family members of Blue Card holders, according to the amendments to the Residence Act.

The Dutch Knowledge Migrant Scheme subjects family members of the skilled worker to a facilitated procedure when applying for a residence permit. When an application is submitted simultaneously with the principal migrant's application, the accelerated procedure applies also for family migrants. In the beginning, spouses are granted a residence permit of one year which will be extended, upon renewal in the next year, to a period equal to that of the principal migrant. ${ }^{35}$ For children, the residence permit is valid for the same period of time as for the principal migrant. Moreover, there are no restrictions for family members to perform in the Dutch labour market. Knowledge migrants as well as accompanying family members are also exempt from integration requirements before entering the Netherlands. Also the spouse/partner and minor children of an EU Blue Card holder have the right to enter the Netherlands together with their sponsor and to take up employment. The family members of EU Blue Card holders have the possibility to acquire an independence residence permit for 'continued stay' (voortgezet verblijf) after a period of two years (one year earlier than other types of family migrants), provided that they have resided for five years within the territory of an EU Member State. ${ }^{36}$ Moreover, all other requirements for an independent permit have to be fulfilled. Table 3.4 compares the countries with regard to family migration possibilities, which clearly shows that the observed countries are attuned to the fact that migration often involves other family members, with the notable exception that the United States does not give spouses the automatic right to work.

Table 3.4: Family reunification rights

\begin{tabular}{l|llll}
\hline & United States & United Kingdom & Netherlands & Germany \\
\hline Family members & $\begin{array}{l}\text { Spouse \& } \\
\text { minor } \\
\text { children }\end{array}$ & $\begin{array}{l}\text { Spouse/same-sex } \\
\text { partner \& minor, } \\
\text { dependent } \\
\text { children }\end{array}$ & $\begin{array}{l}\text { Spouse/partner } \\
\text { dependent } \\
\text { children }\end{array}$ & $\begin{array}{l}\text { Spouse/same- } \\
\text { sex partner \& } \\
\text { minor, } \\
\text { dependent } \\
\text { children }\end{array}$ \\
Waiting period & No & No & No & No \\
Integration conditions & No & No & No & No \\
Right to work for spouses & No & Yes & Yes & Yes \\
\hline
\end{tabular}

Note: The definition of a spouse includes registered partnerships in the named countries.

\footnotetext{
${ }^{35}$ Article 3.67 Aliens Decree.

${ }^{36}$ Article 3.51(6) Aliens Decree.
} 


\subsubsection{Employment Rights and Social Security Provision}

In the United States, $\mathrm{H}-1 \mathrm{~B}$ visa holders are allowed to change jobs under the condition that the new employer files a transfer petition to the USCIS (US Citizenship and Immigration Services) (Section 214 of the Immigration and Nationality Act). The transfers to new jobs are not counted towards the annual quota if the concurrent employment is in a cap-exempt position (positions at certain types of educational, non-profit or governmental organizations (Article 214(g)(5) of the Act)) or if the $\mathrm{H}-1 \mathrm{~B}$ visa holder was already counted towards the cap for his/her first employment and is now transferring to new employment which would otherwise be subject to numerical limitation. Temporary workers generally do not have access to unemployment or any other social security benefits in the United States. Their status is tied to employment and upon losing their job they are required to leave the country. The principal applicant has to prove that he or she is able to support any family member joining them, which is a measure to prevent abuse of welfare. Concerning retirement benefits, the general regulation in the United States is that one must work legally for 10 years in the country. Since the described temporary visa categories mostly limit the stay to a shorter time period, temporary workers are generally not eligible for Social Security retirement benefits (Kapur \& McHale, 2005a). Other benefits including food stamps, supplemental security income, temporary assistance for needy families and Medicaid are not accessible for the first 5 years of residency. On the other hand, state and local public benefits may be available right away, depending on state legislation.

Skilled third-country nationals entering the United Kingdom under Tier 2 have to have a job offer and if they want to change jobs, they have to make a new application for a new Certificate of Sponsorship which meets all the point requirements. Change of employment, however, does not count in the annual limit on the number of certificates available under Tier 2. Immigrant workers in the UK have access to the national health system and are exempted from charges for NHS services (Flynn, 2006). As regards other social security provisions, skilled immigrants generally have no access to public benefits, as the maintenance obligation implies that they may not rely on public funds. The prohibition from reliance on public funds also applies to social housing, which falls under the category of public benefits (Flynn, 2006). A further hurdle is the "habitual residence rule" introduced in 1994. The requirement of habitual residence implies that in order to obtain access to public benefits, highly skilled workers must feature a certain "length, continuity and general nature" of actual residence as well as a "settled intention to remain in the UK" (CIS/1067/1995, Bulletin 129, para. 20) Factors such as the claimant's centre of interest, stable employment, length and 
continuity of residence, reasons for coming to the UK and future intensions are taken into account (CAS, 1994).

As already mentioned, the permanent permit acquired by highly qualified migrants in Germany is neither restricted in time nor in scope, allowing the worker to change his employment position as he wishes. Different rules apply for Blue Card holders. Within the first two years of residence in Germany they have to acquire the approval of the immigration authorities for a change of employment. For each new offer of employment, it has to be demonstrated that the requirements regarding the salary threshold are met. ${ }^{37}$ Section 39(2) of the Residence Act stipulates that the wages, working hours and other terms and conditions of employment of foreign employees may not be less favourable than those applicable to comparable German workers. They also enjoy freedom of association and have free access to the entire territory of Germany. Moreover, highly qualified workers are subject to the same tax regime as native Germans. Highly skilled workers have the right to receive Unemployment Benefit I if they have been employed and subject to social security contributions for at least 360 days during the last two years (Section 123 SGB III) and are registered at the Federal Labour Agency.

In the Netherlands, knowledge migrants are allowed to change jobs or employers within the Netherlands as long as they meet the conditions to qualify as a knowledge migrant. The new employer must inform the IND Office for Labour and Highly Skilled Migrants of the change of employment and provide all necessary documentation. Conversely, employment protection is much more limited. When an employment contract is terminated without this being attributable to the worker, the Knowledge Migrant Scheme allows a period of three months to search for a new job. During the job search period the migrant has to support himself or herself. When knowledge migrants hold temporary contracts which come to an end without foreseen extension, they can no longer stay in the country on the basis of their current residence permits. Similarly, Blue Card holders who become unemployed have a period of three months to find a new job. Once a new job has been found, the IND will consider whether the new employment complies with the requirement of the EU Blue Card. If the Blue Card holder is not successful in finding employment in this period of time, the migrant as well as the former employee must inform the IND and the residence permit will be withdrawn. The situation of a migrant who becomes sick or occupationally-disabled is rather insecure. Essentially, the rule states that as long as a migrant meets the salary criterion, he or she is allowed to hold the residence permit as a knowledge migrant. This criterion can be met on the grounds of the salary or the benefits that a person

\footnotetext{
${ }^{37}$ Section 19a(4) of the Residence Act.
} 
receives in case of illness or partial occupational disability. However, when illness results in complete occupational disability, the residence permit will be revoked. On the contrary, the Netherlands has one of the more attractive taxation regimes when it comes to highly-skilled workers. Fiscal incentives for attracting high earners have been recognized in the so called 30 per cent tax rule. 30 per cent of the salary is reimbursed tax-free if the Tax and Customs Administration considers the applicant eligible (Tax and Customs Administration website). Since 1 January 2014 only employment relationships with a gross annual salary that is at least equal to $€ 36,378$ and those who have completed a Master degree abroad and who are aged 29 years or younger with a salary of $€ 27,653$ qualify for the 30 per cent rule. Moreover, the maximum period for benefiting from the 30 per cent rule has been reduced to eight years. ${ }^{38}$ Table 3.5 compares employment rights and social security provisions in the four countries under consideration.

Table 3.5: Employment rights and social security provisions

\begin{tabular}{|c|c|c|c|c|}
\hline & United States & United Kingdom & Netherlands & Germany \\
\hline $\begin{array}{l}\text { Employment contract } \\
\text { required }\end{array}$ & Yes & Yes & Yes & Yes \\
\hline $\begin{array}{l}\text { Employer portability } \\
\text { options }\end{array}$ & $\begin{array}{l}\text { Yes, new } \\
\text { employer files a } \\
\text { petition }\end{array}$ & $\begin{array}{l}\text { Yes, new employer } \\
\text { files a new } \\
\text { Certificate of } \\
\text { Sponsorship }\end{array}$ & $\begin{array}{l}\text { Yes, within } \\
\text { knowledge } \\
\text { migrant } \\
\text { scheme }\end{array}$ & Yes \\
\hline Social security access & No & No, only health care & $\begin{array}{l}\text { No, only child } \\
\text { benefits }\end{array}$ & Yes \\
\hline
\end{tabular}

\subsection{European vs. US Policies and the Added Value of the Blue Card Directive}

\subsubsection{European and US Policies Compared}

The comparison of European and US Policies applicable to highly-skilled migrants shows that recent legislative changes in the EU Member States have diminished existing differences. All observed countries have in the recent past liberalized their policies and making it easier for the highly-skilled migrants to enter, but this trend "is not going on to the same extent or at the same rate" (Cerna, 2007, p. 2). In terms of eligibility requirements, the US rules are still rather favourable, as applicants are not required to comply with a minimum salary threshold and will be able to qualify for an $\mathrm{H}-1 \mathrm{~B}$ visa on the basis of their professional qualifications or a combination of qualifications and work experience. However, the disadvantages of the American system are the requirement to impose over a work contract and the granting of $\mathrm{H}$ $1 \mathrm{~B}$ visas on the basis of a quota system, which results in a considerable degree of

\footnotetext{
${ }^{38}$ See Wetsvoorstel om te bezuinigen op de bestaande belastingfaciliteiten.
} 
uncertainty for potential applicants. In 2012 the quote for visas was used in 10 weeks, meaning that all other applications have to wait until April next year (Ruiz \& Wilson, 2013). Before the tightening of the immigration system in 2011, highlyskilled migrants were likely to face the smallest hurdles for admission in the UK, as no employment contract was required and eligibility was assessed on the basis of a number of different characteristics of an individual. Since then, the option of migrating to the UK without a prior job offer is limited to 1000 places per year for the so called people of "Exceptional Talent". Now, just like in Germany and in the Netherlands, applicants have to hold an employment contract and comply with a minimum salary threshold. In all countries an exception to the salary requirement is made for high-level academic researchers and teaching personnel.

When looking at specific rules for young migrants and former students, the US does not set a particularly favourable example, as young age is no advantage in the application for an $\mathrm{H}-1 \mathrm{~B}$ visa. However, a special quota applies for former students at US institutions and former students are also eligible for a 12-17 months practical training period. Germany and the Netherlands seem to have gone further than the US in adopting specific rules for young migrants and former students. In particular, the Netherlands has adopted favourable rules for these categories of applicants, as a lower salary threshold applies to migrants below a certain age and to former students from a Dutch or a high-ranking foreign university. Recently Germany introduced a new rule, exempting former students from the labour market test. The UK cut down the previously existing generous options for retaining students upon the end of studies. Extra points used to be granted for young age and poststudy workers benefited from a special points system. Unlike the UK, the Netherlands and Germany still allow former students from their respective countries' universities to search for a job within the highly-skilled category for a period of 12 and 18 months after graduation, respectively.

Concerning the validity of the permit acquired and access to permanent residence status, migrants in the United States are in a privileged position, as they have the possibility to apply for a permanent residence status at any point of time when residing in the US. However, the backload of cases means that in practice they will face a substantial waiting period of around five years before acquiring such a secure residence status. The situation is rather different in the EU Member States, where in principle a period of five years of residence is required in order to become eligible for a long-term residence permit or indefinite leave to remain. An exception is made for highly-skilled migrants in prominent positions in Germany, who are immediately granted a permanent residence permit. Thus, in terms of residence rights, Germany offers the most favourable conditions to eligible highly-skilled 
migrants. In the UK and the Netherlands, on the other hand, requirements for obtaining a long-term residence permit are rather demanding, including language and integration tests which are not applied in the United States. In this respect, these two countries make it quite difficult for migrants to settle down for longer periods of time which is contrary to generous possibilities for short-term settlement.

With respect to family reunification rights, it is notable that all four countries under consideration operate very similar rules with regard to which categories of family members will be admitted (spouses and minor children) and they abstain from applying waiting periods or integration requirements to family members of highlyskilled workers. The US rules are, however, less favourable than European legislation in that they till this point do not allow incoming spouses to work, the limitations of which have already been acknowledged by the planned reforms.

In comparing the employment rights and social security provisions granted to skilled migrants in the observed countries, no country stands out in a particularly positive light. Highly-skilled migrants are in all countries under certain conditions allowed to change their employers within highly-skilled categories of work, which gives them better chances for improving their career prospects. On the contrary, access to social security is, with a noteworthy exception of Germany, very restricted even for the highly-skilled category of migrants. The Netherlands and the UK still make certain positive exceptions while short-term migrants in the United States are basically ineligible for any kind of social security since it is conditional on long periods of residence in the country. Limited social security might work as a disincentive if migrants move due to risk-diversifying strategies.

\subsubsection{The Blue Card Directive: What Does It Add?}

In May 2009 the EU Blue Card Directive for the purpose of highly qualified employment was adopted. The Directives aims to attract highly-skilled workers in order to address labour market shortages in the European Union Member States (see recital 7 of the Directive's preamble). It defines the rules for admission and residence for a period of more than three months applicable to highly-skilled workers and their family Member States. The Directive also contains a number of socio-economic rights and the right to move to a second Member State for employment if certain conditions are fulfilled (Article 1). With the exception of the UK, Ireland and Denmark, the Member States were obliged to transpose the Directive into national law by 19 June 2011 (Article 23). However, it is important to note that the Blue Card only complements rather than replaces national policies for the admission of highly-skilled labour (Article 3(4)). This raises the question of 
whether the introduction of the Blue Card can be expected to lead to facilitated admission procedures or extended rights of third-country nationals. What is the added value of the Blue Card for highly-skilled migrants from third countries? This is a question that we will address in the last part of this chapter.

In June 2011 the implementing provisions of the Blue Card Directive in Germany and the Netherlands entered into force. As pointed out above, the implementing provisions supplement rather than replace national legislation on highly-skilled migrants. Even though the relationship between the Directive and national rules is not entirely clear, Peers has pointed out that Member States remain free to adopt higher or lower standards than the Directive or a combination of both (Peers, 2009). This section addresses the question of the added value of the provisions in the Blue Card Directive. The key question is in how far the implementation process leads to more favourable provisions for the entry and residence of highly-skilled workers in the European Union (Wiesbrock, 2010). In the following part, we assess the likely effect of the introduction of the Blue Card Directive for each of the policy dimensions analysed above.

First, the eligibility criteria in Directive 2009/50/EC are extremely demanding. Potential applicants for a Blue Card have to comply with four sets of requirements. First, they must have higher professional qualifications. This means that they must hold at least a higher educational qualification diploma granted after a recognised three-year programme. As an alternative, five years of professional experience may be sufficient when provided for by national law (Article 2(1)(g)). Secondly, applicants must be in possession of an employment contract or job offer for at least one year (Article 5(1)(a)), which complies with a salary threshold of at least 1.5 times the average gross annual salary (Article 5(2))..$^{39}$ Thirdly, next to the usual requirements of valid travel documents and sickness insurance, Blue Card applicants may be required to provide their address in the potential host country (Article 5(2)). Fourthly, the admission of highly-skilled workers may be restricted by way of national labour market tests and quotas (Article 6). Admission under the Blue Card scheme is in many respects more difficult than admission under the national schemes in Germany and the Netherlands. Even though the salary threshold is lower than the threshold of the national scheme applied in Germany and a bit higher as that applied in the Netherlands, the additional requirements imposed upon applicants are very demanding. In particular, it is notable that Blue

\footnotetext{
${ }^{39}$ The salary threshold may be lowered to 1.2 times the average gross annual salary in respect of certain occupational branches listed in groups 1 or 2 of the International Standard Classification of Occupations, where third-country national workers are particularly needed, see Article 5(5).
} 
Card applicants may be subjected to labour market tests and quotas, which is not the case for the admission of highly-skilled migrants under the national schemes.

As regards special provisions for young migrants and former students, the final version of Directive 2009/50/EC does not introduce any improvements for highlyskilled migrants from third countries. This was different in the original Commission proposal, which contained a special reduced salary threshold for young workers under the age of 30 . Moreover, the Commission had proposed to exempt thirdcountry nationals who have studied in the host Member State from the salary requirement. These special rules for young migrants and former students were not included in the final version of Directive. This renders an application under the Blue Card scheme 'less attractive' for these categories of highly-skilled migrants than under national schemes, where facilitated access is available.

Also with regard to the validity of the permit and access to permanent residence rights, the Blue Card adds little if anything to national admission schemes. The Blue Card is valid for a period of between one and four years, according to a standard period of validity set by the Member States and provided that the work contract has an equivalent duration (Article 7(2)). The Directive does not mention possibilities of renewal. This means that highly-skilled migrants depend upon national law in order to attain access to a permanent residence status. Rules are significantly more favourable in the national legislation of Germany and the Netherlands. Both countries allow for access to permanent residence either directly upon arrival $(G)$ or after the initial residence permit has been renewed. An aspect that might come to the benefit of highly-skilled migrants applying under Directive $2009 / 50 / E C$ is the possibility to accumulate periods of residence in different Member States in order to fulfil the five-year residence requirement to obtain longterm residence status. ${ }^{40}$ In addition, highly-skilled migrants are permitted longer periods of absence from EU territory than other (potential) long-term residents. However, these benefits are partially undermined by the fact that the Blue Card is only valid for up to four years, falling one year short of the necessary residence requirement for obtaining long-term residence status.

Family reunification rights granted on the basis of Directive 2009/50/EC are more favourable than those applicable to 'ordinary migrants' under Directive $2003 / 86 / E C$. They may neither be subjected to a waiting period nor to integration abroad requirements. Family members of highly-skilled migrants also benefit from

\footnotetext{
${ }^{40}$ They must, however, have been resident in the Member State issuing the long-term residence permit for at least two years prior to lodging an application, Article 16(2)(b).
} 
a swifter decision-making procedure and must be immediately granted access to the labour market of the Member State of residence (Article 15). Yet, even though Blue Card holders are in this respect privileged over ordinary family migrants, the Directive does not add any additional benefits to existing national schemes. None of the countries under consideration applies waiting periods or integration abroad requirements to family members of highly-skilled migrants and direct access to the employment market is in all cases guaranteed.

As far as employment rights are concerned, the Blue Card Directive is less favourable than national highly-skilled migrant schemes in Germany and the Netherlands. As opposed to the two national policies, during the first two years of 'legal employment', Blue Card holders are not only tied to highly qualified type of work but also to a specific employer. A change of employment is only possible upon authorisation of the Member State (Article 12(1) in conjunction with Article 12(2)). Even after this initial period, free access to highly-skilled work is only available with the discretion of the host Member State. In Germany, the Netherlands and the UK, on the contrary, highly-skilled migrants are from the start free to change their employer within highly-skilled categories of work. The only visible advantage of the Blue Card scheme is the possibility to take up employment in a second Member State (Article 18). However, it must be stressed that in the case of free movement the same conditions have to be complied with as for the first admission. Member States may even apply quotas in respect of highly-skilled migrants moving from another Member State. These restrictions diminish the value of the free movement provision for highly-skilled workers to a significant extent.

\subsection{Conclusions: Assessing the Attractiveness of National Rules on Highly-Skilled Migration}

The comparison of different policy dimensions with regard to the admission and residence of highly-skilled migrants offers a rather complex picture. It appears that, whilst the US has employed migration policies that allow for the admission of highly-skilled workers for many years, the EU Member States are only gradually transforming their legislation with the view of attracting highly-qualified labour from abroad. Nevertheless, in recent years European migration policies have become increasingly favourable towards the admission of highly-skilled workers and have in certain respects become more attractive than the $\mathrm{H}-1 \mathrm{~B}$ visa in the United States.

In particular, EU Member States have in recent years adopted specifically favourable rules for young migrants and former students and allow spouses of 
highly-skilled migrants to start working in the host country immediately. Rules on access to permanent residence status and citizenship are rather similar in all four countries, except for Germany where a permanent residence permit is acquired directly upon arrival but the acquisition of German nationality is more difficult. The only policy dimension, in which the US still scores better than at least the continental European countries, is eligibility. Rather than setting a fixed minimum salary level, the US makes use of a more flexible admission category of employment in a specialty occupation.

Be that as it may, when looking at various policy dimensions from an objective point of view, the EU Member States are at least as attractive for highly-skilled migrants as the United States. This complies with the previous findings of Cerna (2008), where $\mathrm{H}-1 \mathrm{~B}$ visa ranks lower in terms of attractiveness relative to all the other observed programmes. Cerna ranks the Dutch and the UK immigration policy as they stood in 2007 among the most open programmes for attracting skilled migrants, with the German work permit standing just behind the best performing programmes. $\mathrm{H}-1 \mathrm{~B}$ visa is in the middle field of the overall ranking, but ranks in the lower end of the scale for the work rights of migrants. This outcome is slightly surprising as it runs counter to the general public perception of the United States as an "immigrant friendly" country of destination, and Europe as a place with zeromigration policies. The results also indicate that EU governments have already come quite far in adopting more favourable admission policies in order to compete with the United States and other immigration countries in the competition for the best talents. If we compare the highly-skilled immigration policy indexes in 2004 by Lowell (2005) with an updated similar exercise for the year 2007 by Cerna (2008), we observe a noticeable improvement of ranking for the German work permit scheme and a decline in the ranking for the H-1B programme. We expect a significant drop in ranking of attractiveness also for the UK immigration system if this exercise was to be repeated after the year 2011. Arguably, the largest remaining obstacles to transforming EU Member States into attractive countries of destination for highly-skilled migrants are first, the public perception of the EU as 'fortress Europe' and, second, the fragmentation of the European labour market and the lack of free movement rights for third-country nationals.

Concerning the first issue, it is important to note that the public discourse at the European and national levels is not only with regard to highly-skilled migration but also in respect to family reunification, integration, citizenship, illegal migration and asylum. These are all important factors in shaping the image of Europe as a potential destination for third-country nationals. Concerning the second aspect, the Community has made a first attempt at harmonizing the rules on highly-skilled 
migrants and offering them an opportunity to move to other Member States with the adoption of Directive 2009/50/EC. However, the negotiating process for adopting the Blue Card Directive and the discrepancy between the proposed and the final version of the Directive speak against Sassen's (1998) theory of transnationalization in migration policy formation and related hypothesis in favour of convergence among policies due to efficiency arguments (Cerny, 1996; Zaletel, 2006). It turns out that the European migration policy arena is closer to Shachar's view (2006) who maintains nation states in control over policy changes. The final version of the Directive, as adopted by the Council of Ministers, leaves a lot to be desired in terms of offering an attractive option for highly-skilled migrants. In particular, highly-skilled migrants only acquire the right to move to a second Member State after eighteen months and must comply with the same requirements as for entry. This means that the possibilities for highly-skilled migrants to rely on Directive 2009/50/EC in order to benefit from a larger European labour market have been reduced significantly.

Moreover, the distinction between high and low skilled labour in all countries under consideration can be criticized from a human-rights perspective. It underlines the utilitarian approach to labour migration dominant in migrant receiving countries, allowing for the entry and residence of third-country nationals only and as long as they are considered 'useful' for the national labour market. Moreover, the exclusively demand-based approach as well as the restricted rights granted to labour migrants can be criticized. Consequently, in spite of the fact that EU Member States have become more attractive for highly-skilled migrants in comparison with the United States, many aspects of EU and national labour migration policies remain open to discussion and criticism. 


\section{Trends in migration policy in the Netherlands}

\subsection{Introduction}

Forecasts already in 2004 were pointing to serious shortages of skilled workers to meet industry demand in the Netherlands (OECD, 2004). The employment market forecasts for the period 2005-2010 showed an average annual employment growth of 70,000 people (ROA, 2005). The decrease in labour force of the Netherlands is expected to grow in the future (De Jong \& Van Duin, 2011). The Labour Participation Advisory Committee expects a shortage of 375.000 workers in 2015, increasing to perhaps 700.000 in 2040 (Advies Commissie Arbeidsparticipatie, 2008). The estimates show that demand will be higher for highly educated due to the fast growth of certain sectors and due to increasing complexity of work. The foreseen shortage of highly-skilled labour is high on the agenda of preoccupations for the Dutch government. The Labour Participation Advisory Committee (2008, p. 100) which addressed the question of facilitating labour participation affirmed that skilled migrants may be beneficial for the Netherlands as they can fill gaps in the labour market, create new business opportunities and support the internationallyoriented knowledge society of the Netherlands. Attracting workers with needed skills from abroad is increasingly regarded as an important approach to alleviate the skill gap, for which the regulatory obstacles should be as low as possible.

As the first step in this direction, the Netherlands introduced a Knowledge Migrant scheme (Kennismigrantenregeling) in October 2004. The aim was to improve the current situation of a relatively low share of foreign skilled workers in the labour force. The proportion of university graduates among all third country migrants was only around 23 percent in 2009 (Biffl, 2012, p. 7). Moreover, the government constantly revises the policies so there have been a couple of procedural changes in the last years that aimed to remove the obstacles in the regulations. A memorandum Towards a Modern Migration Policy explains the basic aim is to make the Netherlands more attractive for high-level knowledge workers and talented scientists, and to respond more closely to the needs of Dutch society, companies and knowledge institutes' (Ministry of Justice, 2006, p. 4). The Bill was adopted in 2010 and finally, on 1 June 2013, a reformed Modern Migration Policy Act (Wet modern migratiebeleid), which has a starting point in selectivity, came into force.

The reason for highlighting the case study of the Netherlands is to give an example of a knowledge-driven economy with current and anticipated demographic 
changes which has not long ago taken up a proactive approach in attracting workers with needed skills from abroad. Its position in the competition for internationallymobile human capital is more or less unmapped. As such, it represents an example of a new destination country for skilled immigration which is of particular interest for this thesis. While attempting to see how new destination countries joined in this global race, after comparing policies with traditional immigration countries (Chapter 3), a closer look is paid to one particular new destination country and observe its development of migration policies. This chapter describes trends in immigration policies of the Netherlands after the Second World War, showing a continuous closure of options for family immigration and low-skilled immigration, in general. It describes the recent trends in immigration and places it in the framework of immigration policy developments. The subsequent section describes the current legal framework for migration to the Netherlands. It also specifically addresses the developments of migration from India to the Netherlands and presents the current figures for stocks of Indian migrants. Indians represent the biggest migrant group who enter the Netherlands with the Knowledge Migrant scheme and as such denote an interesting example of showing the new dynamics of migration flows. The chapter concludes with assessing the Dutch immigration policy and general conditions in the country in terms of attractiveness using conceptual framework presented in Chapter 2.

\subsection{Trends in immigration in the Netherlands}

The Netherlands has a long history of migration. While in the past, increases in both, emigration and immigration, lead to fluctuations and almost balanced trends in population numbers, this has changed after the 1960s. The historical trends of migration flows from 1860 onwards are depicted in Figure 4.1. Continuous net immigration made the Netherlands a country of immigration since 1967 (Lucassen \& Penninx, 1997). 
Figure 4.1: Net migration from 1860 to 2000

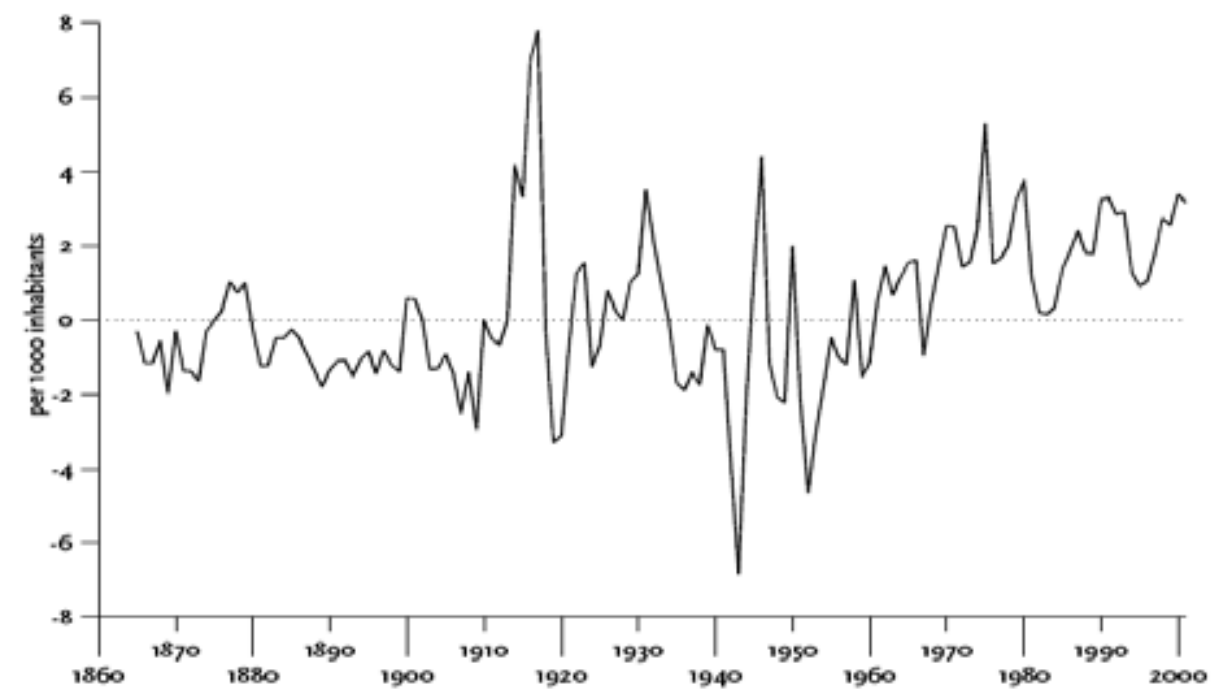

Source: Statistics Netherlands

This trend held till recently, when for a short period from 2003 and 2007 emigrants for the first time outnumbered immigrants (Figure 4.2).

Figure 4.2: Total immigration and emigration, 1995-2011 (in absolute numbers)

$\multimap$ Immigration $\quad \longrightarrow$ Emigration including administrative corrections

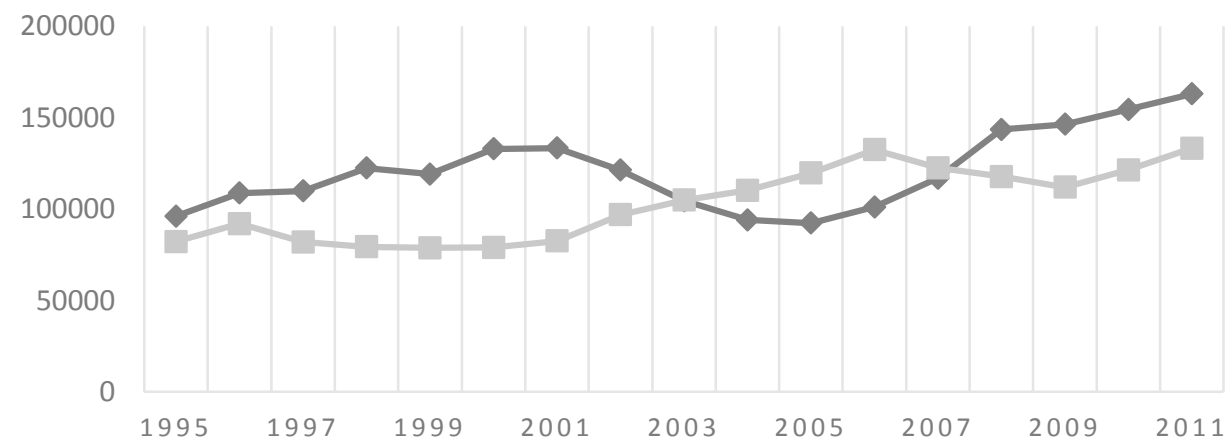

Source: Statistics Netherland (CBS), accessed 13 October 2013

Consequences of past colonialism and labour migration in the late 1960s and early 1970 s can explain a large share of immigration to the Netherlands. After the Second World War, migration was boosted by the decolonization process. Declaration of Indonesian independence in 1945 and ensuing armed conflict were conducive to a large wave of immigration from the old colony. Approximately 350,000 people used 
the right to repatriate to the Netherlands although for many it was their first time in the country. Additionally, many Moluccan soldiers that served in the Dutch army, accompanied by their families, settled in the Netherlands. Further flows of immigration that came as a consequence of the past colonialism were from the overseas territories in the Caribbean. Large numbers of people from Suriname moved to the Netherlands in the 1970s in the anticipation of former colony's independence. Pending independence raised doubts for many Surinamese whether economic and political stability can be upheld also in the independent state. The Netherlands' Antilles and Aruba, the last overseas territories of the Kingdom of Netherlands, have also represented a large source of immigrants throughout the history. In the past it was more common that the wealthy Antilleans came to look for better career opportunities or for education to the Netherlands. However, from the 1990s onwards, it became more common also for poorer strata of society to try their chances in the European part of the Kingdom. This has been mainly due to the difficult and unstable economic conditions in their homeland (Amersfoort, 2006).

High concentration of immigrants from former colonies in the Netherlands results from the existence of prior links between sending countries and the receiving country, which strongly supports claims of migration systems theory. Furthermore, conditions in the sending countries have often worked as a push factor for migration, either because of political instability or economic insecurity. Giving an option for repatriation, as in the case of Indonesia, or providing a choice to opt for a Dutch citizenship has made conditions in the receiving country additionally attractive for these groups of migrants. Government policies that have allowed for such options have clearly worked as a pulling factor to the Netherlands. When more restrictive admission policy was introduced in the 1980s, Surinam was considered as one of the countries with high emigration potential. Instead of the desired aim to reduce immigration, the announcement of mandatory visas resulted in a boost in immigration. Due to the fear that such possibilities will not be available in the future, large number of people decided to use the chance prior to the introduction of the new policy (Amersfoort, 2011).

Following the post-war economic expansion, the Netherlands started to face labour shortages and like several other Western European countries recruited guestworkers to fill these gaps. Prior to any agreements, Mediterranean migrant worker started to come from neighbouring countries on their own accord. Since the Dutch economy was quite slow in recovering after the WWII compared to countries like Germany, Belgium or France, labour recruitment started rather late. The first recruitment agreement, regulating the conditions for selection, work and stay of migrant workers, was signed in 1960 with Italy. In the following years, similar 
agreements were signed with several other mainly Mediterranean countries: Spain (1961), Portugal (1963), Turkey (1964), Greece (1966), Morocco (1969), Yugoslavia and Tunisia (1970).

Recruitment agreements with sending countries were a way to regulate migration flows that had been largely organised by employers. The agreements specified that the mode of entry would be a work permit, which was to be obtained in the country of origin. As was generally the case with bilateral agreements, they tended to recognise rather than create migration flows. Migrant workers were able to come to the Netherlands also before these agreements and then, only after finding employment, applied for residence permits (Geddes, 2003). Even after the recruitment agreements were signed with a number of countries, there were still workers coming spontaneously instead of being recruited directly by employers (Penninx, 1994). These migrants arrived illegally or as tourists and acquired the necessary documents upon finding a job. Although nowadays they would be defined as illegal immigrants, at the time, pressure of labour shortages in post-war Europe encouraged the governments not to impose strict rules on labour migrants, whether they arrive through the "legal" channels or not. Migration through unofficial channels was tolerated because, unlike for recruited workers, employment for them did not require any lengthy procedures and was therefore more flexible. Because of the severe competition for guest workers between recruiting countries and companies, the state considered the interests of Dutch companies of primal importance. It was accepted by all social partners that economic growth could only be sustained by relying on foreign labour (BruquetasCallejo, Garcés-Mascareñas, Penninx, \& Scholten, 2007).

However, when after a long period of economic expansion the first recession came about in 1966-67, these workers were the first to feel the consequences. The granting of work permits to migrants who were not recruited was restricted, as was the renewal of work permits. Employment offices gave priority to Dutch unemployed over foreigners. In 1968, partly in response to pressure exercised by trade unions, the government decided to stop all labour migration outside the official channels. Only workers who had been recruited or who had been granted a preliminary residence permit in their country of origin were eligible for a work permit (Bonjour, 2005).

What stroke the most in the first recessions is that the demand for foreign workers remained unchanged even during the recession. Most of them kept their jobs since they were flexible in changing positions and there were mostly enough places to be filled in one or another industry. The experience of a recession combined with a large number of foreign workers in the labour market made it apparent that the 
demand for foreign labour was a structural feature of the Dutch economy. The recession had a minor and a short-lived impact on the 'guest workers' since the economy picked up again and the entry of migrant workers reached a new peak in 1970-71. The second economic crisis had much more significant, in fact dramatic, impacts on the economic and political context of migration. The so-called oil crisis of 1973 had immense effects for the Dutch economy and the coupled economic recession led to the loss of large number of jobs. The sectors that employed guest workers were hit disproportionably hard. Although the recruitment policies assumed that these workers would leave the Netherlands once their services are not needed anymore, this did not happen at the predicted extent. The recruitment policies, however, considered these workers as temporary immigrants who will return to their home countries. Based on the assumption of the temporariness and to emphasize this in a common discourse, a German word Gastarbeiter/gastarbeider was borrowed to describe these migrants. While workers of certain nationalities indeed left the Netherlands on a large scale, there were especially guest workers from the poorest countries of recruitment that decided to stay. For migrants from Turkey and Morocco the motivation for returning to their countries of origin was low. The high oil prices and the global economic downturn hit these countries even harder than the European. Next to the worsened economic situation, the political situation was increasingly instable due to coup d'état's (1971 and 1972 in Morocco and 1971 in Turkey). Moreover, immigration to the Netherlands became more difficult for non-EU citizens so those already staying there did not want to jeopardize their chances of not being able to enter again. Another important reason for staying in the Netherlands was the fact that like any other unemployed person, the guest workers were entitled to a salary replacing income. All these factors combined led to a large numbers of mostly Turkish and Moroccan workers staying in the country who were later on joined by a much larger group of fellow citizens. This created a tension between the norm of not being a country of immigration and the fact of increasing immigration and permanent residence of immigrants (Amersfoort, 1999; De Haas, 2007; Doomernik, 2007; Entzinger, 1985; Tinnemans, 1994).

The norm that the Netherlands is not an immigration country was repeated several times in the official documents. The "Memorandum Foreign Employees" (Nota Buitenlandse Werknemers) from 1970 was the first government document that aimed at establishing a coherent approach to the issue of labour immigration. It evidently presupposes its temporary character by noting that "the Netherlands is 
certainly not an immigration country" ${ }^{11}$ while at the same time acknowledging the contribution which the workers made for the Dutch economy. Recognizing the experience from the first recession when the demand for foreign labour remained high despite increased unemployment rates, the Netherlands government started to consider labour immigration as a manner to cope with structural shifts in demand for labour (Bonjour, 2005). To reconcile this inconsistency in the approach to the labour migration, the "Memorandum Foreign Employees" called for a rotation system, where foreign workers could stay in the country maximum up to two years. This proposal was quickly dropped after it was faced with strong criticism in the parliament and beyond. As mentioned earlier, the oil crisis in 1973 marks a significant turning point in the labour market situation as well as in the policymaking of the Dutch government related to migration. In this context, the Den Uyl government in 1974 in a "Memorandum of Reply" repeated and even emphasized that the Netherlands "is not an immigration country and should not become one", because of its high population density resulting in "symptoms of congestion" and severe housing shortages (Bonjour, 2005). The government recognized the responsibilities it has over the guest workers and therefore set itself a policy objective to accommodate them to Dutch society for as long as they would remain in the Netherlands. Since the immigrant stay in the Netherlands was still considered to be temporary, integration with preservation of cultural identity' was the policy's motto (Oers, Hart, \& Groenendijk, 2006). Next to the recognition of obligations towards immigrants, the major objective of the policy was to limit labour immigration to a minimum necessary that is needed for the Dutch economy. In line with this policy, tighter control on the entry of foreign workers was announced as well as setting up a maximum number of migrant workers at a country and company level. As for labour migration, the basic policy of the Dutch government since the turn in 1973 is to not allow permanent settlement unless there are compelling reasons to do the opposite (Doomernik, Gsir, \& Kraler, 2005). Different than in France and Germany where a formal recruitment stop was introduced, labour migration continued to be possible even after the Netherlands proclaimed itself closed to labour migration (Bruquetas-Callejo et al., 2007). First, immigration was regulated by the Foreign Employees Act (WABW) from 1979 to 1995 and from 1995 onwards through the Foreign Workers Employment Act (Wet Arbeid Vreemdelingen, WAV, 1995). The admission was a temporary matter and only the workers that were already in Europe were admitted. Employers were only allowed to employ workers from outside the European Economic Area (EEA) if they could prove that suitable employees could not be found within this area (Roodenburg,

\footnotetext{
${ }^{41}$ Tweede Kamer 1969-1970, 10 504, nr. 2, p. 10.
} 
Euwals, \& Rele, 2003). Although the end of labour immigration was proclaimed, the above mentioned policies continued to channel the entrance of those workers that were considered beneficial to the Dutch labour market.

Compared to other industrialized countries, the early 1970s characterized Dutch migration politics by its relative progressiveness. Despite the fact that immigration was becoming increasingly restrictive, the government has to be acknowledged for its broad, internationally oriented approach that wanted to alter the structural conditions as the cause of migration. For that, the Dutch economy had to be restructured in a way that there would be no more need for low-qualified foreign workers while at the same time the economic situation in the countries of origin had to be reconsidered. The Den Uyl government set itself an ambitious objective of changing the economic system in a way that labour intensive industries are placed in the South instead of in the North. To accomplish that aim, the government would strive to liberalise trade policies of developed countries and selectively stimulate industrialisation in developing countries. Such positive measures in the field of development policies can be considered as a 'moral compensation' for increasingly restrictive entry policies (Bonjour, 2005).

In the attempt to minimize the number of foreign workers and due to the view that labour migration would be of a temporary character, more effort was placed on the actual realization of returning migrants back to their home countries. The government proposed to give a bonus for each worker that would voluntarily and permanently return. After a strong criticism against such a premium, the government dropped the proposal. Nevertheless, attempts to encourage return migration took hold in a number of projects. The best-known of these programmes is the REMPLOD (Reintegration of Emigrant Manpower and the Promotion of Local Opportunities for Development). In 1974, when this programme was implemented, it was for the first time that migration policies were extended to include the development policies in the countries of origin. The project dealt explicitly with fighting the causes of work migration in the countries of origin. The initial plan was for the returnees to five countries where most workers came from, to be included in local development projects as founders of new businesses. However, after only two years of project implementation and intensive research accompanying this implementation in Turkey, Morocco and Tunisia, it was recommended to bring the programme to an end. The government wanted to concentrate on job-creation in developing countries in a broader sense without special consideration on returnees. Despite this negative recommendation, a small portion of the REMPLOD funds was further dedicated to supporting the establishment of new businesses by returnees. The programme was entirely stopped in 1984 . The reasons given were 
the high costs of the programme and that the encouragement of return migration was no longer in accordance of the new Dutch politics on minorities (Aumüller, 2004; Van Dijk \& Penninx, 1976). After the increasing acceptance that most migrants are staying in the country, the government no longer placed much importance on return migration.

By the end of the 1970s it became clear that many immigrants will stay in the country. A couple of violent events caused by a small group of immigrants drew attention to the position of immigrants that have been in the Netherlands for a good number of years and have yet been considered temporary. These tensions started the debate on the need to acknowledge permanent residence for some immigrant groups and the need to introduce integration policy for them (Penninx, Garcés-Mascareñas, \& Scholten, 2005). The highly influential report 'Minorities Policy' (Minderhedenbeleid) from the Netherlands Scientific Council for Government Policy (WRR, 1979) acknowledged that the immigrants residing in the Netherlands should be expected to stay permanently, while at the same time called for more integration policies. The need for further integration only applied for the immigrants already in the country while at the same time, the Dutch government decided to undertake serious efforts to limit the number of foreigners settling in the country. The recommendations from the Scientific Council were taken as a basis for the new policy. Foreign Employees Act (Wet Arbeid Buitenlandse Werknemers, WABW, 1979) from 1979 took the changed circumstances into account and admitted that the stay of foreign workers in the Netherlands is not of a temporary nature. In its 'Memorandum Minorities Policy' (Nota Minderhedenbeleid) ${ }^{42}$, issued as a draft in 1981 and in its final version in 1983, the centre-right government under Prime Minister Ruud Lubbers also acknowledged that the Netherlands had de facto become an immigration country. Parallel to increased focus on integration, a more restrictive admission policy was introduced first on labour migration, and later, on family migration and asylum. Visa requirements for certain countries with a high emigration potential, including Turkey, Morocco and Surinam, were introduced. Following the new approach to immigration, family reunification was first made easier since it was considered positive for the incorporation into the host society. On the other hand, the regulations for labour migrants' children were applied more strictly and in the future further measures were introduced to curb family migration. The new assumption in the Dutch migration policies from now on was that many migrants will stay in the country. This acknowledgment led to attempts in different fields to improve their economic and social situation while at the same time it also meant that entry policies had to be further restricted.

\footnotetext{
${ }^{42}$ Ministry of the Interior (Ministerie van Binnenlands Zaken), 1983. Nota Minderhedenbeleid. The Hague: SDU
} 
Despite the fact that immigration policies were becoming more restrictive with every new measure, the Netherlands were confronted with the continuing permanent relocation of newcomers. Labour migration was no longer the main source of settlement migration. During the 1970s, large numbers of people from Suriname relocated to the Netherlands due to former colony's imminent independence. Migration laws did not apply to the Surinamese since they were Dutch citizens since 1954. Post 1973, when it was agreed that Suriname will become independent by the end of 1975, there was an enormous growth in immigration. The number of Surinamese in the Netherlands surged from 51,000 in 1972 to 145,000 in 1980 , which is substantial considering that the total population of Suriname in the beginning of the 1970s was 385,000 (Amersfoort, 2011, p. 4). It was agreed that visa regulations will only come into force in 1980 , so until then Surinamese could travel freely to the Netherlands. The agreement was that people would have the nationality of the country where they were settled in 1975 and could apply for the nationality of their country of birth if they had migrated and were not living in their country of birth (Amersfoort, 2011, p. 16).

Another important reason for the increase in migration was family migration as a consequence of the previously strong labour flows. Since the end of recruitment period, Turkish and Moroccan communities grew to around ten times the size due to family reunification, family formation and childbirth (Doomernik, 2007; Ersanili, 2007). When many guest workers decided to stay over regardless of recruitment stop, they were joined by their families in the coming years. Instead of single men that had made up the large majority of immigrants in the sixties, the seventies witnessed the immigration of women and children. Family reunification peaked in the early 1980s. While in the early seventies, there were 55,000 Turkish and Moroccan guest workers in the Netherlands and about 20,000 family members, 25 years later these ethnic groups, including the second generation, accounted for half a million people in total (Roodenburg, 2000). Despite the fact that the process was not welcomed by the government, the normative principles of a family unity weighed strongly in government policies. Especially the approach following the "Memorandum Minorities Policy" from 1983 came favourable for family migration. Now that the permanency of immigrants' stay was accepted as a starting point for integration policies, family became part of the integration process. Living with the family was considered beneficial for incorporation into society (Bonjour, 2006). In this regard, liberal family migration policies were an important part of the ethnic minorities' policy, and particularly, of their emphasis on socioeconomic integration with respect to own cultural identity (Bruquetas-Callejo et al., 2007). A shift from a group-oriented approach to one that puts responsibility on an individual led to the introduction of more restrictive family migration measures. In the 1990s, family 
unity was no longer considered as a contribution to integration but more as a curse. Such view persists till today. The Law on Integration Abroad (Wet Inburgering in het Buitenland, WIB, 2006) clearly sees family migration as a potential threat to integration. The declared goal of the 'civic integration test abroad', which is required for migrant coming on the grounds of family reunification or formation, is to improve the integration conditions for new migrants. Though the reduction of the number of immigrants allegedly is not the primary goal of the policy, the government still expects a drop in family migration (Stb. 2004, 496) ${ }^{43}$. That in fact happened when the number of applicants for family formation or reunification dropped significantly in the period from 2003 to 2006 (see Figure 4.3). Especially family migration of people originating from Turkey, Morocco and Surinam, major countries of origin of family migrants, has decreased significantly since 2003 which can most probably be related to the policy measures, aimed to limit family migration, introduced in 2004. Since 2007, nonetheless, the number of family migrants has increased again on account of immigration from other EU Member States (the largest sending countries among which are Poland, Germany and Bulgaria) and sending countries of large numbers of asylum (like Somalia and Iraq) and knowledge migrants (India and the United States). In 2011, the countries of origin with the largest numbers of family migrants were Poland $(4,120$ family migrants), Germany $(2,375)$ and Turkey $(2,285)$ (Statistics Netherlands (CBS)). Figure 4.3 shows us that despite a decrease in migration due to this reason, family migration remains an important driving force.

${ }^{43}$ Decree of 29 September 2004 to amend the Aliens Decree 2000 in connection with the implementation of the 2003/86/EC Directive and a number of other family reunification, family formation and public order issues, Stb. 2004,496 
Figure 4.3: Immigration of non-Dutch nationals by year of arrival and migration motive from 1995 to 2011 (in absolute numbers)

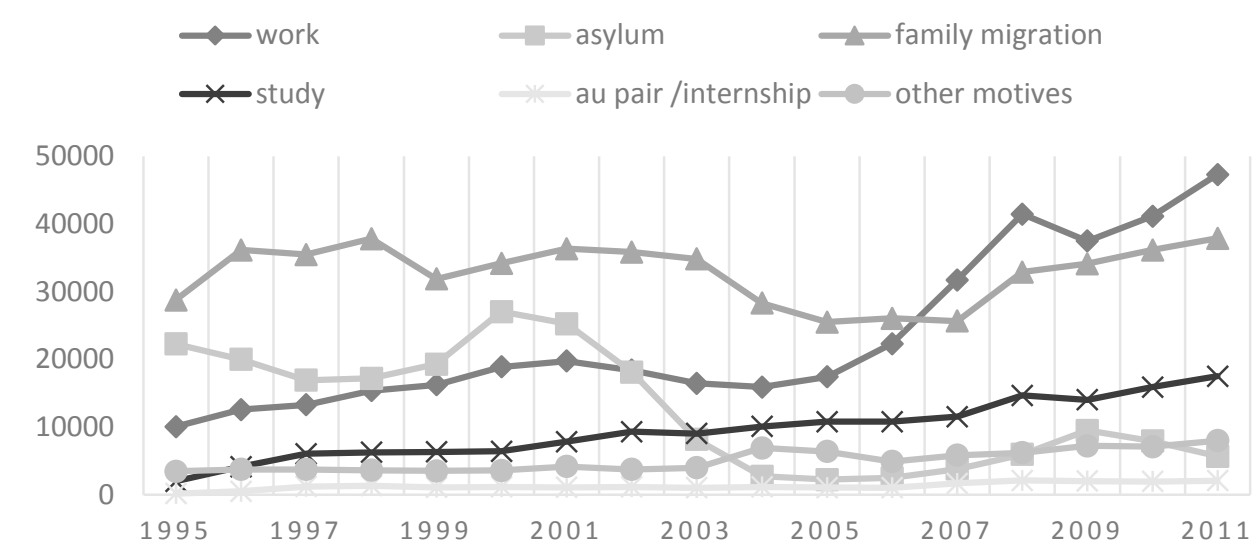

Source: Statistics Netherland (CBS), accessed 13 October 2013

Next to migration as a consequence of the decolonization process and labour migration which later led to an increased numbers of family migrants, asylum used to be the third relevant source of migration. Since the 1980s, refugees have increasingly contributed to immigration in the Netherlands. Number of requests continued to be high throughout the 1990s, till in 2001 the Aliens Act tightened the criteria for a refugee status and introduced a fast-track assessment. Number of application dropped significantly from 43,560 in 2000 to 9,780 in 2004 (Ersanili, 2007). There was a slight increase in the number of applications again in 2006 but in 2012 there were again just 9,810 applications. Considering that the Netherlands was placed in 2012 only on the eleventh place in terms of number of asylum seekers per inhabitants ( 0.46 per 1000 inhabitants) among EU member states, we assess that the decrease in the number of requests does not represent a general trend in migration but has to do with the introduction of the new policy. While in the times of heavy migration of asylum seekers to the Netherlands many application for a refugee status were declined, in the last years more permits are granted than requested as to remedy the past inconsistencies. Main countries of origin for asylum seekers in the Netherlands are Iraq, Afghanistan and Somalia (Ministry of Security and Justice, 2013, pp. 14-17).

As illustrated in Figure 4.3, in 2007 labour migration once again became the most prominent migration motive for the first time since the early 1970s. Table 4.1 discloses that much of the increase in immigration in recent years can be attributed to migration from other EU Member States, with the highest increase in immigration from Poland. Since close to 80 percent of all labour migrants come 
from other EU Member States, this explains the change of trends in labour migration. The largest group of migrants from other EU Member States came from Poland $(18,384)$ and Germany $(13,462)$. The Polish arrival is rather recent, spiked by Poland's ascension to the European Union and the large emigration that followed as many Polish left for Western Europe and elsewhere in search of work. When ten countries joined the European Union in May 2004, the Netherlands introduced a transition period, meaning that workers from eight Central and Eastern European countries (Malta and Cyprus were exempt from these regulation) were considered in a preferential manner but still needed a work permit. Since May 2007, workers from these countries are allowed to work in the Netherlands without any restrictions which is visible in the increase in the number of labour migrants. With the enlargement of the EU in January 2007, an increase in migration is noticeable from Romania and Bulgaria compared to previous years. Absolute numbers of migrants from these two countries stayed rather limited which is among other reasons related also to the fact that Romanian and Bulgarian employees still needed a work permit to work in the Netherlands until the beginning of 2014. Since the beginning of the economic crisis, there has also been a steep increase in immigration from Spain, Italy and Greece (CBS).

Table 4.1: Immigration flows by major countries of origin from 2004 to 2012

\begin{tabular}{l|lllllllll}
\hline \multicolumn{1}{|c|}{$\mathbf{2 0 0 4}$} & $\mathbf{2 0 0 5}$ & $\mathbf{2 0 0 6}$ & $\mathbf{2 0 0 7}$ & $\mathbf{2 0 0 8}$ & $\mathbf{2 0 0 9}$ & $\mathbf{2 0 1 0}$ & $\mathbf{2 0 1 1}$ & $\mathbf{2 0 1 2}$ \\
\hline Total & 94019 & 92297 & 101150 & 116819 & 143516 & 146378 & 154432 & 162962 & 158374 \\
Bulgaria & 418 & 416 & 451 & 4837 & 5148 & 4272 & 4121 & 5213 & 4852 \\
China & 3649 & 3341 & 3325 & 3911 & 5121 & 5241 & 5333 & 6177 & 5936 \\
Germany & 8671 & 9134 & 10424 & 10981 & 12929 & 12818 & 13914 & 13851 & 13462 \\
France & 2871 & 3018 & 3357 & 3725 & 4513 & 4305 & 4328 & 4551 & 4309 \\
Greece & 913 & 977 & 1175 & 1272 & 1674 & 1791 & 2369 & 3206 & 3916 \\
India & 631 & 1214 & 2046 & 2502 & 3405 & 3069 & 3168 & 3774 & 3899 \\
Italy & 1583 & 1717 & 1966 & 2182 & 2987 & 3139 & 3271 & 3493 & 4085 \\
Morocco & 3625 & 2357 & 2007 & 1532 & 1836 & 1922 & 1988 & 2212 & 1807 \\
Poland & 5073 & 6672 & 8214 & 10126 & 13890 & 13027 & 14782 & 18937 & 18348 \\
Portugal & 1349 & 1258 & 1696 & 2096 & 2645 & 2627 & 2216 & 2412 & 2703 \\
Romania & 711 & 559 & 718 & 2347 & 2390 & 2155 & 2594 & 2721 & 2459 \\
Spain & 2826 & 2885 & 3372 & 3902 & 5101 & 5883 & 6109 & 6631 & 7526 \\
UK & 5405 & 4903 & 5550 & 6368 & 7536 & 7376 & 7068 & 7455 & 7446 \\
USA & 4345 & 4410 & 5191 & 5549 & 5951 & 5746 & 5832 & 6167 & 6037 \\
\hline
\end{tabular}

Source: CBS, Accessed 13 October 2013 
Numbers of immigrants entering the Netherlands clearly respond to the country's economic situation, with a roughly two-year delay (Cörvers, Muysken, de Neubourg, \& Schliwen, 2009, p. 49). With an increase of unemployment, immigration dropped from 2001 to 2004 but picked up soon again after national economic situation started improving. Migration from other European countries has been shown as particularly cyclical and correlated with unemployment situation in the Netherlands (Duin \& Nicolaas, 2006).

While most recent policies that have been described so far try to curtail immigration of low skilled labour force, other forms of international migration such as of highly skilled workers are increasingly encouraged and facilitated. The pointsystem for those that want to establish themselves as self-employed in the Netherlands, the admission scheme for Highly Educated Migrants, the job-search year after completion of studies at a university in the Netherlands and the so called "30 per cent tax rule" were introduced in addition to the Knowledge migrant scheme in order to make the Netherlands more attractive for the highly-skilled migrants.

\subsection{Legal framework for labour migration}

The legal framework for labour migration in The Netherlands is laid down in the Aliens Act 2000 (Vreemdelingenwet 2000 - Vw 2000) and in Foreign Workers Employment Act (Wet Arbeid Vreemdelingen - WAV). The decision on granting a residence permit is made on the basis of the $V_{w}$ 2000, which is further defined in lower level legislation and regulations such as the Aliens Decree 2000 (Vb 2000), the Aliens Act implementation guidelines 2000 (Vc 2000), and the Regulations on Aliens 2000. The Aliens Decree 2000 lists purposes for which a residence permit in the Netherlands can be granted. The Modern Migration Policy Act, in force since June 2013, amends the Aliens Act 2000 with respect to regular admission policies, so this chapter pays special attention to the recently changed conditions for labour migration.

The main policy instrument that regulates employment of "third country nationals" is the Foreign Workers Employment Act (WAV). The Act is entirely demand-driven, meaning that employers are responsible for obtaining the work permit (tewerkstellingsvergunning - TWV). Responsibility for granting work permits for the benefit of the third country national to the employers is held by the Ministry of Social Affairs and Employment. It is responsible for the functioning of the labour market and a work permit enables the Ministry to regulate and control the labour inflow. Preferential treatment is given to 'priority labour supply' which means that a third country national can only be hired when the employer can demonstrate that 
every possible attempt has been undertaken to employ a person of Dutch nationality or the nationality of one of the countries within the EEA. The Act specifies that employers who want to hire a worker from outside the EEA must first apply for approval from the Centre for Work and Income (the CWI). Next to "priority labour supply' condition, the permit will only be granted if other conditions, like 'terms of employment', 'working conditions and a possible test on housing are met as well. Every application for a work permit relates to a specific job and requires an individualized labour market test. In practice, the Foreign Workers Employment Act in particular relates to seasonal labour in agriculture and some specific branches and occupations experiencing shortages in labour supply. Whether an employment permit is issued always depends on weighing the employers' interests against the interests of a European labour supply and/or against the interests of recruiting unemployed nationals (Doomernik et al., 2005; Ministry of Social Affairs and Employment, 2008).

The WAV does not apply to all labour migrants. As previously mentioned in chapter 3 , more lenient criteria apply to those migrant who fall under the Knowledge migrant scheme. In addition, freedom of movement of workers applies to people with the nationality of one of the EEA Member states ${ }^{44}$. Often, a work permit is also not required for foreign nationals residing in the Netherlands on the basis of family reunification when no restrictions apply to the principal migrant. If the principal migrant is only allowed to work on the basis of TWV, then the same applies for the family member. A work permit is also not required for foreign nationals who perform certain types of work which entails only short periods of time on an occasional basis in the Netherlands, such as visiting lecturers or artistic performers. Also foreigners that want to establish themselves as self-employed in the Netherlands do not fall in the scope of WAV. The Foreign Workers Employment Act regulates the demand-driven migration, which is the basis for the Dutch labour migration policy. The only two supply-driven schemes are the self-employed persons' scheme and the Highly Educated Migrant Scheme. The next section briefly explains the conditions for foreigners who wish to work in the Netherlands as entrepreneurs and for those who could come to the Netherlands on the basis of a point system used in the Highly Educated Migrant Scheme.

\section{Self-employed}

Article 3 of WAV specifies that no work permit is needed for self-employment. The demand-driven scheme cannot apply for them since they do not have an employer.

\footnotetext{
44 The Netherlands has imposed transitional restrictions to the labour market for people with Romanian and Bulgarian nationality, meaning that they still need work permits until the end of 2013.
} 
Migrants who wish to establish themselves in The Netherlands as independent entrepreneurs can apply to the IND for a residence permit with a 'self-employment' restriction. There are some basic conditions to be fulfilled for all foreign nationals who want to practice as independent entrepreneur: 1. Professional competency requirements: the foreign national must be able to demonstrate that he meets any special competency requirements for the particular profession he wants to practice; 2 . The business activity must serve a vital Dutch interest according to the Ministry of Economic Affairs.

Since May 1, 2006 new criteria apply for permission for foreigners to set up a business in the Netherlands. The objective of the government is to remove the obstacles for the highly-skilled migrants to settle themselves as self-employed. The new regulation is used internally by the IND to assess their residence applications on the basis of a point system which looks at applicants' personal characteristics; business plan and added value for the Dutch economy (see Table 4.2) (Social Economic Council, 2007). The Ministry of Economic Affairs has developed this point system as the basis of its advice to the IND regarding the vital Dutch interest served by the foreign national. The clearly defined point system makes the evaluation of the application more straightforward and faster. Applicants are no longer assessed as to whether the same work could be completed by a Dutch person or a foreigner with a valid residence permit. Further advantage of this system is also in a clearer perspective of a potential migrant for his eligibility for a residence in the Netherlands on the basis of self-employment.

Table 4.2: Scheme of the point system for self-employment

\begin{tabular}{|c|c|c|}
\hline Criterion & Testing for & Points (max) \\
\hline \multirow{5}{*}{$\begin{array}{l}\text { Personal experiences (minimum } \\
30 \text { points) }\end{array}$} & Education & 35 \\
\hline & Entrepreneurship experience & 35 \\
\hline & Work experience & 10 \\
\hline & Income & 10 \\
\hline & Experience in the Netherlands & 10 \\
\hline \multirow{3}{*}{$\begin{array}{l}\text { Business } \\
\text { points) }\end{array}$} & Market potential & 30 \\
\hline & Organisation & 20 \\
\hline & Finances & 50 \\
\hline \multirow{3}{*}{$\begin{array}{l}\text { Added value for the NL (minimum } \\
30 \text { points) }\end{array}$} & Innovative value & 20 \\
\hline & Creation of new working places & 40 \\
\hline & Investment value & 40 \\
\hline
\end{tabular}

Source: Social and Economic Council, 2007 
As of October 2010, the points-based system was made easier for applicants. Now, the third criterion is no longer decisive and it is also considered sufficient to score 45 points or more in each of the first two categories. ${ }^{45}$

Certain nationalities are excluded from the point-system and do not have to prove their activity would have to serve Dutch economic interests. These are nationals of European Economic Area member states and Switzerland, Turkey, Japan, the United States and long-term residents of European Union countries. Besides the self-employment scheme there is another supply-driven scheme based on a point system, designed to attract top talent to the Netherlands.

\section{Highly Educated Migrants Scheme}

In January 2009, the Netherlands introduced a new pilot Admission Scheme for Highly Educated Migrants which allows recent graduates to get an authorisation for temporary stay without a job-offer (Besluit van de Staatssecretaris van Justitie van 12 december 2008, 2008/30). In addition to the academic-degree requirement, foreign nationals will be assessed on the basis of a point system, which awards points with regard to age, level of education and other performance indicators in the Netherlands. Conditions for obtaining a one-year residence permit and look for employment in the Netherlands are already explained in Chapter 3. The advantage of this scheme is that one may obtain a residence permit without a prior job offer. Foreign nationals admitted in the Highly Educated Migrants Scheme can either get a job as a knowledge migrant, otherwise employers will be required to have a work permit (IND, 2013e; Nuffic, 2011). After the evaluation in 2011 the scheme was extended for further two years on 1 April 2012 and expanded to students from a list of top 200 universities (instead of top 150 as previously) from the major university rankings (INDIAC, 2013).

\section{Modern Migration Policy}

After being approved by the Dutch Lower House on 16 February 2011 and by the Senate on 5 June 2010, the Modern Migration Policy Act (Wet modern migratiebeleid $)^{46}$ finally came into force in June 2013 . It brings significant changes for entrance and residence of foreign nationals, making immigration to the Netherlands increasingly characterized by selectivity. There is a strong favour towards the highly-skilled migrants. It amends the Aliens Act 2000 with respect to regular admission policy, having consequences for employment, study and family reunification. One of the important developments as compared to the earlier policy

${ }^{45}$ http://www.abil.com/news_detail.cfm?NEWS_ID=65

${ }^{46}$ Wet modern migratiebeleid, juli 2010, Staatsblad 2010, 32.052, nr. 290 
is the strengthening of the position of employers as so-called sponsors, which gives them more obligations. Companies have to be authorized as sponsors by IND. The sponsor is given an independent position and may submit residency applications on behalf of the foreign national he wants to bring to the Netherlands. They have the duty to ensure careful recruitment and selection and they are also responsible for foreign national's compliance with the statutory rules; also for his return. Sponsors and foreign nationals will be able to use the Admission and Residence Procedure (Toegang en Verblijf - TEV), which means they will then no longer have to submit two separate applications for a regular provisional residence permit (Machtiging Voorlopig Verblijf - MVV) and a residence permit (Verblijfsvergunning Regulier -VVR). ${ }^{47}$ With regards to higher education field, the educational institution is the sponsor for the 'study' purpose of stay. A foreign student who needs a residence permit for study purposes can only come to the Netherlands if he is going to study at an educational institution which the IND has recognized. Same as for highly-skilled migrants, sponsors will then no longer have to submit two separate applications for a regular provisional residence permit (MVV) and a residence permit for students. Under the new Act, educational institutions must monitor study progress. A foreign student must pass at least $50 \%$ of the nominal study workload for (the part) of the academic year. In the event of insufficient study progress, the educational institution must report this to the IND and the residence permit may be withdrawn (IND, 2013a, 2013c).

With the intention of simplifying and accelerating procedures, previous 28 purposes of stay are replaced with only eight, five economic clusters (cultural exchange, labour temporary, study, labour regular, and knowledge and talent) and three social clusters (relatives and family, temporary humanitarian reasons, and special residence) (IND, 2013d). The same residence restrictions apply within a cluster. People who come to the Netherlands within the cluster of seasonal work and exchange programmes are not allowed to extend their period of stay beyond the initial validity of their residence permit. They are allowed to stay for a strictly limited period with a maximum duration of one year. The residence permit within this tier is tied to the specific purpose of stay for which it was granted and it is not possible to switch to another purpose. After the expiry of the residence permit, it is necessary to leave the Netherlands and the time spent under this cluster does not give you any rights towards permanent stay. They also do not have the right to family reunification or social security assistance (IND, 2013b). This is different from the earlier scheme where all foreign nationals were free to work on the Dutch labour market after three years of residence on the basis of TWV. With the Modern Migration Policy Bill this is no longer the case since the government wants to stress

\footnotetext{
${ }^{47}$ Blauwdruk modern migratiebeleid, juli 2008, Kamerstukken II 2007-2008, 30 573, nr. 10
} 
the 'enforceably temporary character' of temporary and circular migration (Wiesbrock, 2010). People coming under the clusters of regular labour and studying hold more rights than the first two. These two clusters are designated for regular labour migrants from third countries who require a work permit and for students in tertiary education. Unlike the previous category of migrants, these applicants are allowed to change their employer or institution of engagement on condition that they stay within the purpose of stay for which their residence permit was granted. They can extend their residence permit, which is in the first place tied to the duration of employment contract. In addition, they are eligible for applying for a permanent residence permit after five years of residence. They have the right to family reunification and family formation, and they also build their social security benefits (IND, 2013a, 2013c).

Table 4.3: Number of granted residence permits for knowledge migration by nationality, for main source countries, from 2005 to 2009

\begin{tabular}{l|llllll}
\hline Nationality & $\mathbf{2 0 0 5}$ & $\mathbf{2 0 0 6}$ & $\mathbf{2 0 0 7}$ & $\mathbf{2 0 0 8}$ & $\mathbf{2 0 0 9}$ & $\begin{array}{l}\mathbf{2 0 0 5 - 2 0 0 9} \\
\text { Total }\end{array}$ \\
\hline All source countries & 1.613 & 3.592 & 5.177 & 6.645 & 5.058 & 22.085 \\
India & 280 & 935 & 1.514 & 2.115 & 1.585 & 6.429 \\
USA & 286 & 527 & 734 & 838 & 704 & 3.089 \\
China & 98 & 142 & 267 & 349 & 310 & 1.166 \\
Japan & 88 & 189 & 259 & 317 & 313 & 1.166 \\
Turkey & 79 & 160 & 256 & 341 & 255 & 1.091 \\
\hline
\end{tabular}

Source: IND

Migrants coming to the Netherlands under the cluster of knowledge and talent have the most preferential treatment. They do not require a work permit or are subjected to any labour market tests. They can freely move on the labour market as long as they are employed within the knowledge sector. Their residence permit is in the first place granted for the duration of the employment contract of a maximum five years, and can be thereafter extended. Highly-skilled migrants also have the right to family reunification and family formation and build their social security entitlements, as was previously elaborated in Chapter 3.

Following the liberalization of the immigration policies, the number of people who came under the category of knowledge migrants has been growing since the introduction of the Knowledge Migrant Scheme in 2005. Probably due to the worsened economic situation in the Netherlands, there is drop in the number of permits in 2009, but the recent figures show a new increase in 2010 and 2011, still below the peak year of 2008 (INDIAC, 2013). In seven years of the scheme's existence till 2011, over 32.000 residence permits had been issued to knowledge 
migrants, the largest share among which were issued to Indian nationals. For the period until 2009, for which the numbers of granted residence permits for knowledge migration are available by nationality, it is shown in the .

Table 4.3 that Indians obtained close to 30 percent of all permits. The shares of main nationalities with knowledge migrant permits have remained unchanged in the last years. In the reported period from 2008 to 2011, Indians represent a particularly dominant group among migrants coming to the Netherlands under the Knowledge Migrant scheme (32 percent), followed by Americans (13 percent) and Chinese (6 percent) (INDIAC, 2013).

It appears that Knowledge Migrants scheme attracts a group of migrants with specific characteristics. The most represented age group within knowledge migrants is in the category up to 30 year old (47\% in the period from 2008 to 2011) and it is mostly granted to male migrants ( $76 \%$ in the same period). The knowledge migrant scheme is mostly used by the labour sector defined as "IT and other business services" by ISCO-88 (38 percent in 2008-2011), followed by the sectors "Industry", "Academic education", "Trade" and "Financial services" (INDIAC, 2013). In the following section I specifically address the developments of migration from India to the Netherlands and present the current figures for stocks of Indian migrants. A more detailed account is presented for this group of migrants in the Netherlands since they represent the largest group among skilled migrants.

\subsection{Immigration of Indians to the Netherlands}

There has been a large increase in immigration from India to the Netherlands in the recent years. From 1995 to 2004, annual immigration from India accounted for around 700 to 800 people per year. The flows gained momentum in 2005, when 1,320 Indians migrated to the Netherlands, which continued to increase in the following years, leading to an immigration flow of 4,124 people in 2012 (Figure 4.4). As emigration flows of Indians from the Netherlands follow the same trend, we can assume that a vast majority of these flows are of a temporary character. 
Figure 4.4: Immigration and emigration of migrants born in India, 1995-2012
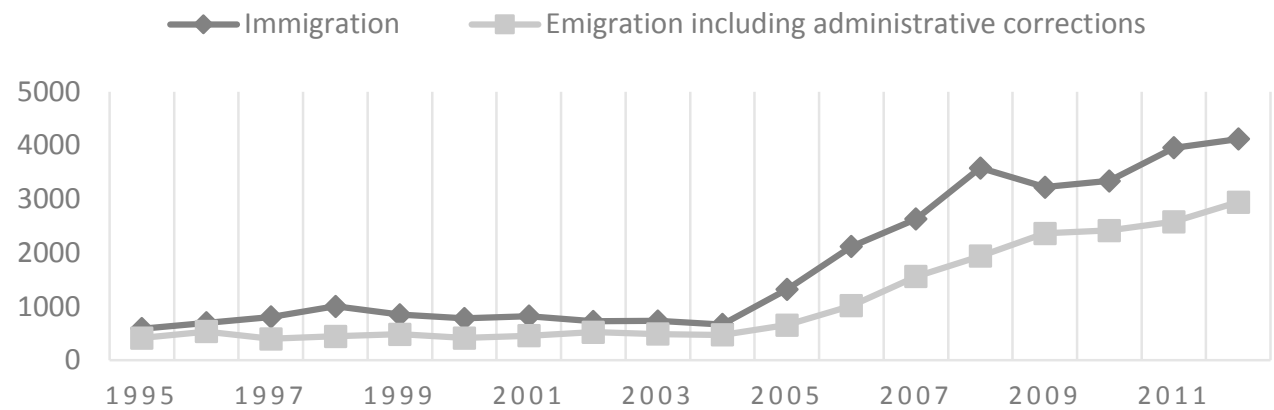

Source: CBS, accessed 29 January 2014

Next to a more recent wave of migration which is reflected in the above figures of knowledge migrants, The Netherlands also has a large Indian community from Suriname, descendants of indentured workers, who later migrated to the Netherlands. There are significant differences between both groups in terms of their socio-economic profiles. Today's migration from India is characterized by immigrants, who are more educated and more strongly represented among professionals and scientists as the earlier migrants of people of Indian origin. One relevant difference among the two groups is that the Surinamese Indian community moved to the Netherlands permanently, while recent migrants mostly consist of highly-skilled professionals who move to the Netherlands temporarily for specific work-related reasons.

Another characteristic of recent Indian migrants in the Netherlands is a strong male dominance (Table 4.4). In 2011, the share of male migrants among all Indians arriving that year was as high as 62.8 percent. Male dominance is especially strong among those who came to the Netherlands for work and studies-related reasons. 86 percent of all Indians coming to the Netherlands for work are men, which is much more than among labour migrants from other countries of origin. For example, in the case of immigration The United States of America men represented 68 percent of all labour migrants arriving to the Netherlands in 2011. Also among student flows, a vast majority are male students. It is noticeable that with a general increase in migration from 2000 to 2011 the reasons for migration have not changed much for Indians. Labour migration remains the most dominant of different forms of migration, followed closely by migration for family reunification and family formation. There are clear differences in this respect between men and women. While majority of men come to the Netherlands on a work visa, women join them as trailing spouses. They represent a big majority in migration from India for the purpose of family migration (75.5 percent in 2011). 
Table 4.4: Immigration flows of people born in India from 2000 and 2011 by migration motive; total number and percentage of male

\begin{tabular}{|c|c|c|c|c|c|c|c|c|c|c|c|c|c|c|}
\hline & \multicolumn{2}{|c|}{ Work } & \multicolumn{2}{|c|}{ Asylum } & \multicolumn{2}{|c|}{$\begin{array}{l}\text { Family } \\
\text { migration }\end{array}$} & \multicolumn{2}{|c|}{ Study } & \multicolumn{2}{|c|}{$\begin{array}{l}\text { Au pair / } \\
\text { internship }\end{array}$} & \multicolumn{2}{|c|}{$\begin{array}{l}\text { Other } \\
\text { motives }\end{array}$} & \multicolumn{2}{|l|}{ Total } \\
\hline & No. & $\begin{array}{l}\% \\
\text { male }\end{array}$ & No. & $\begin{array}{l}\% \\
\text { male }\end{array}$ & No. & \begin{tabular}{|l|}
$\%$ \\
male \\
\end{tabular} & No. & $\begin{array}{l}\% \\
\text { male }\end{array}$ & No. & $\begin{array}{l}\% \\
\text { male }\end{array}$ & No. & $\begin{array}{l}\% \\
\text { male }\end{array}$ & No. & $\begin{array}{l}\% \\
\text { male }\end{array}$ \\
\hline 2000 & 270 & 86.7 & 7 & 85.7 & 291 & 29.9 & 87 & 74.7 & 6 & 83.3 & 66 & 24.2 & 727 & 56.7 \\
\hline 2001 & 290 & 90.0 & 11 & 72.7 & 303 & 28.4 & 86 & 75.6 & 7 & 71.4 & 73 & 47.9 & 770 & 59.6 \\
\hline 2002 & 234 & 85.9 & 16 & 81.3 & 270 & 31.1 & 114 & 75.4 & 1 & & 48 & 31.3 & 682 & 58.5 \\
\hline 2003 & 229 & 88.2 & 5 & 60.0 & 277 & 28.2 & 126 & 83.3 & 3 & 66.7 & 45 & 31.1 & 685 & 59.0 \\
\hline 2004 & 197 & 87.3 & 4 & 50.0 & 233 & 38.2 & 121 & 77.7 & 12 & 83.3 & 53 & 39.6 & 621 & 62.5 \\
\hline 2005 & 490 & 85.1 & 1 & 100 & 444 & 35.6 & 202 & 80.7 & 18 & 77.8 & 113 & 49.6 & 1268 & 63.7 \\
\hline 2006 & 971 & 88.8 & - & & 704 & 33.1 & 327 & 82.3 & 18 & 94.4 & 42 & 40.5 & 2062 & 67.8 \\
\hline 2007 & 1504 & 88.4 & 3 & 100 & 721 & 24.4 & 284 & 76.8 & 11 & 81.8 & 61 & 59.0 & 2584 & 68.6 \\
\hline 2008 & 1991 & 88.7 & 9 & 66.7 & 1064 & 22.7 & 381 & 78.7 & 13 & 46.2 & 55 & 67.3 & 3514 & 67.1 \\
\hline 2009 & 1451 & 86.6 & 11 & 63.6 & 1146 & 28.5 & 477 & 77.4 & 20 & 55.0 & 56 & 55.4 & 3161 & 63.3 \\
\hline 2010 & 1619 & 83.0 & 2 & 100 & 1061 & 25.5 & 514 & 77.0 & 28 & 57.1 & 42 & 57.1 & 3266 & 62.9 \\
\hline 2011 & 1898 & 85.9 & 3 & 100 & 1377 & 24.5 & 525 & 79.6 & 29 & 65.5 & 49 & 63.3 & 3881 & 62.8 \\
\hline
\end{tabular}

Source: CBS, accessed 6 December 2013

As previously mentioned, the Indian nationality is the most dominant in the Knowledge Migrant Scheme. Very few Indian migrants make use of the regular work permit system. Since the introduction of the Knowledge Migrant scheme the number of regular work permits issued to Indians went down from 310 in 2005 to only 190 granted work permits in 2008, showing diversion to the new scheme. Predominantly, Indian knowledge migrants come to the Netherlands to work in the "IT and other business services" (70 percent). The others are dispersed in smaller numbers in sectors like "Academic education" (5 percent) and "Industry" (4 percent) (INDIAC, 2013, p. 42). An important factor in the growing number of Indian IT workers in the Netherlands is the presence of Indian companies in the region (Bal, 2012, p. 16). A large majority of highly-skilled Indians work in the Amsterdam Metropolitan Area, where many Indian ICT companies like Tata Consultancy Services or Infosys set up European branches. Most Indian companies work in business process outsourcing, hence the large share of Indian migrants engaging in IT and business services.

Few Indians obtained residence permit as a scientific research under EC Directive 2005/71 since it came into effect in 2008. In the period from 2008 to 2011, just above 200 Indians came to the Netherlands under this permit, which is far behind 1200 Chinese with this type of permit. Also within other types of permits for researchers (for unpaid researchers) and for work on a self-employed basis there 
are only a few Indians. Some Indians also made use of the opportunity to stay in the Netherlands after completed degrees from Dutch educational institutions to search for employment. Around 260 found employment as knowledge migrants after making use of the orientation year and 20 as scientific researchers in the period from 2005 to 2011, which is not negligible among the total of 2,730 and 280, respectively (INDIAC, 2013, pp. 57-58).

According to NUFFIC, there were around 800 Indian students in the Netherlands in the year 2012, which is relatively little if we compare this number with 5,700 Chinese students (Nuffic, 2013). However, this number has been growing in the past years from 326 in 2005 . Also Table 4.4 showing the immigration flows by migration motives shows a similar increase from 208 in 2005 to 474 in 2009 of Indians coming to the Netherlands for the purpose of studies. Most Indian students are enrolled in a programme specialized in technology. Second most common discipline is economics. The single institution with most Indian students is Delft University, followed by Eindhoven University of Technology and Wageningen University (Nuffic, 2010, 2013).

\subsection{Conclusion}

The current situation, with a relatively low share of foreign skilled workers in The Netherlands, is a result of Dutch colonial past and guest workers in the late 1960s and early 1970s. Several policy measures have contributed to, if not caused, such an outcome. From 1960, when the first recruitment agreement was signed, till the outbreak of the oil crisis in 1973, the government encouraged immigration of workers to support the booming Dutch economy. Any worker that was recruited by employer or came independently in the country was welcome and there were no major difficulties involved for obtaining the necessary documents. The main factor in migration decision for the case of labour migration in the 1960s and 1970s was a huge demand for labour in the Dutch economy. Major reasons for those workers that decided to settle down permanently in the Netherlands concerned the lack of prospects in their home countries. Although there were some attempts made to encourage return migration, the Dutch government did not take on policies that would inflict return of guest workers to their countries of origin. They were granted permanent residence permits and families were allowed to join them. As part of the ethnic minorities' policy in the 1980s, family migration was considered advantageous for integration into society. From 1990s on this is no longer the case. Several measures have been introduced since then with the objective to reduce family migration. As recent trends show, this goal has been attained with steady decrease of migration on the basis of family formation or reunification. Especially 
family migration of people originating from Turkey, Morocco and Surinam, major countries of origin of family migrants, has decreased significantly which can most probably be related to the policy measures, aimed to limit family migration, introduced in 2004. Since 2007, nonetheless, the number of family migrants has increased again on account of immigration from other EU Member States and sending countries of large numbers of asylum and knowledge migrants. Family migration remains an important driving force, however after adamant regulatory efforts to decrease it, labour is since 2007 again the most prominent migration motive. Although this time with a different composition of sending countries. Much of the recent increase in immigration can be attributed to intra-EU migration. In addition, a high increase in immigration from India is noticeable. Knowledge migrant scheme, which was established for attracting non-EU skilled labour, opened entry for migrants from non-traditional sending countries. Efficient application procedures are recognized as an important means of sending out positive signals to prospective migrants. Several schemes have been introduced with this objective, the most recent being the Modern Migration Policy Act, which places most of the burden with the application procedure on the employer. The simplicity and straightforwardness of salary criterion of the Knowledge migrants' scheme and of the point-systems of the Highly-Educated migration scheme and self-employment scheme makes it easier for prospective applicants and employers to assess their options. Several other measures show that the Netherlands has indeed incorporated many elements in the immigration policy to make the country more attractive. Among others, it takes migrants' family considerations into account, it allows migrants to change sponsors within the same cluster. Indian migrants, who represent the largest group among the highly-skilled are typical for the type of workers the Netherlands aims to attract. The following part of the dissertation is devoted to their case study. 


\section{Part II}




\section{The Case of India: methodology and descriptive statistics}

\subsection{Introduction}

This dissertation contains a case study of India, including a quantitative and qualitative analysis aimed at understanding the drivers of student mobility from India. This chapter elaborates on the reason why India was chosen as a case study of migrants' decisions and presents the methodology followed in the Indian case, including information on the specific research questions and hypotheses.

Migration in the context of this study comprises both moving abroad to undertake tertiary education as well as for labour migration. The two are often related as many people transition to the labour market after obtaining overseas qualifications or may even work and study simultaneously. In the context of contemporary migration processes, people often change from one migrant category to another or fall in-between such categories, turning migration categories increasingly blurring and transitional in nature (Collinson, 2009; Hailbronner \& Koslowski, 2008; King, 2002). Skilled Indians increasingly emigrate as students through the academic stream. The growth of international student mobility from India in recent years is remarkable. Internationalization of higher education has been a major driving force behind this trend, as well as a rising middle class in India which is increasingly able to afford foreign university programmes (Kumar, Sarkar, \& Sharma, 2009). In addition, foreign student policies have become a tool in the international competition for skilled persons. This takes place through the so-called "two-steps migration"; namely, first through the attraction of international students, and then by their retention as skilled workers for the national labour markets (OECD, 2010a). In fact, many students decide to gain working experience abroad upon completion of their studies. The figures from the National Science Foundation in the United States show that more than three-quarters of foreign recipients of science and engineering doctorates plan to stay in the United States and about half already have a secured employment at the time of the doctorate receipt. Stay rates are in particular high for science and engineering doctoral recipients from India, as in the period 2004-2007 89 percent reported plans to stay in the United States (NSB, 2010). Even though this share has decreased in the past years and in a similar manner figures show that fewer migrants from India stay permanently abroad, there is still a strong interconnectedness between postgraduate education and work abroad (Wadhwa, Saxenian, Freeman, \& Salkever, 2009). 
The choice to specifically study decisions of Indian students is based on two factors. Firstly, the Indian student population, allowing for high numbers of respondents, forms an excellent sample population for studying international student flows. Large student population and the quality of educational system guarantee large outflow of students on a yearly basis. India as the second major country of origin for internationally mobile students accounts for 5,5 percent of the global total of internationally mobile students (OECD, 2010d; UNESCO-IUS, 2010b). Secondly, India is considered to be among the winners in terms of having an overall positive effect from skilled migration (Beine et al., 2003), which supports our choice for India as a case study.

The study is focused on students in the field of science and engineering. Since this dissertation focuses on the pattern on migration where individuals are able to choose among many different locations and where the role of the state is seen as one about attracting potential migrants, we purposely select the group of students with most transferable and sought after skills. To begin with, students in science and engineering possess knowledge and skills which are highly transferrable across international borders. This in turn makes them more mobile and free to choose the location for their further studies as well as for work. In addition, most developed countries are, for different reasons, facing labour supply shortages in this field. Scientists and engineers are involved in innovation and development of new products and technologies (Freeman, 2006), which may consequently lead to economic growth of the receiving country. Attracting students and workers in this specific field is therefore seen as an instrument to sustain economic growth through the process of research and development and is therefore introduced in immigration policies of most developed countries.

Existing studies on migration decisions place an emphasis on immigrants in destination countries using either census data or survey data in destination countries (Belot \& Hatton, 2008; Docquier et al., 2006; Geis, Uebelmesser, \& Werding, 2008a; Vogler \& Rotte, 2000). Papers analysing migrant's location choices based on international macro-panel data find that besides GDP per capita, also shorter distance, common language and colonial ties have a positive effect on the choice of a particular destination country (Docquier et al., 2006; Mayda, 2005). This type of analysis, however, does not show us differences between population groups, like for example, differences in destination choice between parents and people without children. Papers which use micro data can overcome this limitation but they are restricted to analysing migrants' choices only for those migrants who are based in the selected few countries (Constant \& D'Agosto, 2008; Geis et al., 2008a). Any larger international micro database, such as European Labour Force 
Survey or EU-LISC, have a limitation that migrants are likely to be under covered since these surveys aim at the whole resident population. In any case, data sources from destination countries only include those who have already migrated, while those remaining in their home countries are not included. With a disposition to answer why some people leave their home countries while others stay, the survey required data from those who stay as well as from those who leave. Therefore, this study builds on the data obtained in a survey in a source country, which was specifically designed to study at the individual level what influences Indian students in their decision to migrate.

The analysis of the survey is supplemented by results from qualitative interviews with a sub-sample of students from the observed universities, which gives further insight into the decision making regarding migration intentions. The following sections describe the research setting, the survey data and the qualitative data collection and present the sample characteristics. In order to be able to introduce the selection of the sampling frame, we first briefly describe the educational system of India with the explanation of the different institutional set-ups. The final part lays out the specific research questions and hypotheses to be tested in chapter six and seven of the dissertation.

\subsection{Education system in India}

As the country that embodies many of the world's superlatives, India has one of the largest higher education systems in the world. According to Annual Report by the Ministry of Human Resource Development (2009), in the academic year 20092010, India had a total population of 13.64 million students enrolled in either universities (12.24 percent) or colleges (87.76 percent) ((Ministry of Human Resource Development (Government of India), 2010). ${ }^{48}$

The institutional framework of higher education in India consists of Universities, Institutions "deemed to be universities" (explanation see below), Institutes of National Importance, Institutions established under State legislation and colleges affiliated to the University. In 2010 there were 504 Universities and university-level institutions, out of which there were 40 Central Universities, 296 State Universities, 130 Deemed Universities, 33 institutions of national importance and 5 Institutions

\footnotetext{
48 In the academic year 2008-2009, in which the survey for this study was implemented, India had a total population of 12.37 million students enrolled in either universities (12.84\%) or colleges (87.16\%) (Ministry of Human Resource Development (Government of India), 2009).
} 
established through various State legislations ${ }^{49}$. In addition, there were 26,951 affiliated colleges. (Ministry of Human Resource Development (Government of India), 2010). Central Universities are established by the Government of India and receive grants from the University Grants Commission. State Universities, on the contrary, are run by the State Governments in each of the States in India and, if they were established after 17 June 1972, they are, in principle, not eligible for funds from the Central Government (Ministry of Human Resource Development (Government of India), 2010). The status "deemed to be University" is a status of autonomy awarded by the Department of Higher Education, Ministry of Human Resource Development, to institutions which work at high standards in specific areas of study and have an academic status and privileges of universities (Ministry of Human Resource Development (Government of India), 2010). Institutes of National Importance are a few selected institutions, which offer programmes of high quality and relevance in engineering, technology, applied sciences, and management (Salmi, 2009). All 15 Indian Institutes of Technology (IITs) are established as "Institutions of National Importance" under the Institutes of Technology Act, 1961. Their main objective is to train scientists and engineers at the world-class level, to conduct research and disseminate knowledge (Ministry of Human Resource Development (Government of India), 2010).

According to the Annual Report from the Ministry of Human Resource Development, there were around 1.67 million students in university-level institutions and close to 12 million students in affiliated colleges in the academic year 2009-2010. Out of total enrolment of students, 41.40 percent are women. According to UNESCO statistics, the total enrolment for tertiary education in 2007 was 12,853 students, out of which 40 percent were women. Representation of women remains at the same level (40 percent) for the first and the second stage of tertiary education (ISCED 5 and 6 ) (UNESCO-IUS, 2009). UNESCO and OECD data do not provide distribution of students by fields of education for India. The University Grants Commission (UGC), the government regulatory body for higher education, provides the most comprehensive statistics on the situation of tertiary education in India. However, the latest report available is from the academic year 2005-2006. The total enrolment reported for that year is $11,028,000$ students, out of which 45.13 percent have been enrolled in faculties of arts, followed by sciences ( 20.45 percent), commerce/management (18.01 percent), and engineering/technology (7.21 percent) (UGC, 2006).

\footnotetext{
${ }^{49}$ Five institutions established under various state legislations are the following: Nizam's Institute of Medical Sciences, Hyderabad; Sri Venkateswara Institute of Medical Sciences, Tirupati; Indira Gandhi Institute of Medical Sciences, Sheikhpura, Patna; Sher-e-Kashmir Institute of Medical Sciences, Srinagar; Sanjay Gandhi Postgraduate Institute of Medical Sciences, Lucknow.
} 
The Indian education system has a special feature of providing special provisions for scheduled castes and scheduled tribes in order to improve their educational base. For the admissions to universities, 15 percent of all positions are allocated to students belonging to scheduled castes, and 7.5 percent to students from tribes. With the aim of filling these pre-reserved slots, the qualifying criteria for admissions are lowered for this group of students (UGC, 2006).

\subsection{Selection of universities}

The data were collected during two field visits in India. The data collection took place in March and April 2009 among students at Jawaharlal Nehru University (JNU), Institute of Technology - Banaras Hindu University (IT-BHU), and University of Jammu. In August 2009, the data were collected at the Indian Institute of Technology (IIT) Delhi and Indian Institute of Science (IISC) Bangalore.

The selection criteria to sample these higher education institutions were 1) quality of education, 2) geographic location and 3) the diversity of heterogeneous Indian education system. All chosen institutions are reputed for offering high quality higher education, as either recognized by the University Grants Commission (UGC) or graded by The National Assessment and Accreditation Council (NAAC) under the 'A category' denoting "High level of academic accomplishment as expected from an institution" (NAAC, 2007). IIT Delhi was also ranked among the world's top 200 universities according to The Times Higher Education QS 2009 (QS Quacquarelli Symonds Ltd., 2009).

The universities in the study are located in four different Indian states. Their geographical distribution is presented in Map 5.1. 
Map 5.1: Geographical location of selected universities ${ }^{50}$

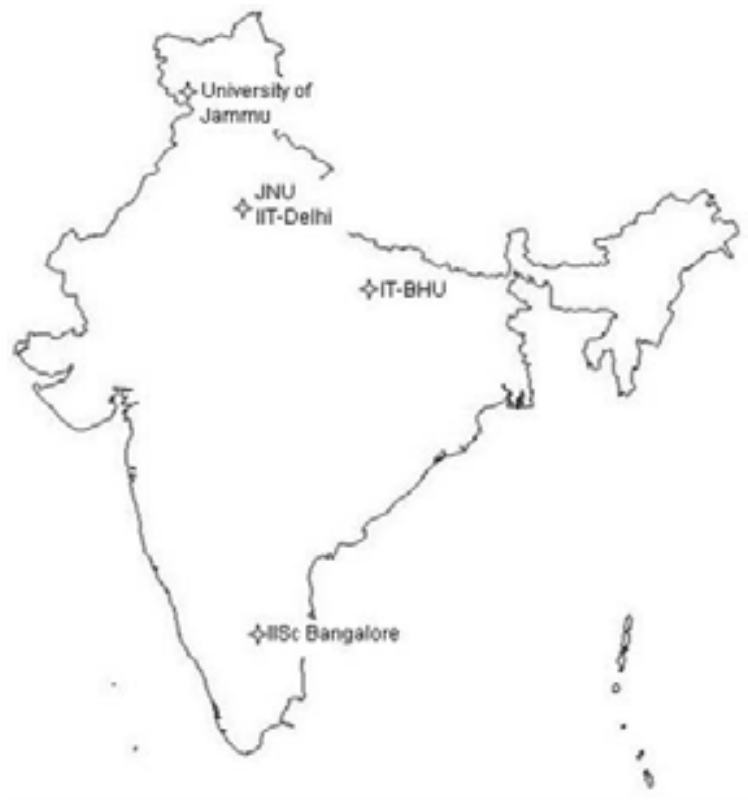

In addition to quality criteria, the universities used in the study also allow us to exemplify the heterogeneity of the student population and different education systems in India. Each of institutions is an example of a different educational setup as presented in Table 5.1. The selection includes two examples of Central Universities (JNU and BHU), an example of a State University (University of Jammu), an institution "deemed to be university" (IISC) and an example of an institution of National Importance (IIT Delhi). IIT Delhi is one of the fifteen autonomous technology institutes, which were established by the Indian Parliament as the "Institutes of National Importance" to raise top-quality technological manpower. It offers undergraduate and post-graduate programmes. JNU is also located in New Delhi, but is, in contrast to the IITs, a research-oriented postgraduate university. It's a multidisciplinary university, organized in ten different schools and four specialised centres. It was one if the first universities which were given the status of "Universities with Potential for Excellence". IT-BHU is a constituent unit of Banaras Hindu University, located in Varanasi (Uttar Pradesh). It's an engineering school and according to Union Cabinet's decision from 2008, IT-BHU is now in the process of converting to a status of an IIT (Government of India, 2008, March 28). The admission to IT-BHU follows equivalent examination as for the entrance to IITs. IISC Bangalore (Karnataka) is a highly-ranked research institution with very selective admission procedures. Departments of the Institute are divided in the categories

\footnotetext{
${ }^{50}$ Note: The map of India is neither authentic nor its boundaries shown are officially validated.
} 
of sciences and engineering, with some of them offering programmes based on course work and others based on research. It offers Masters and PhD degrees. The University of Jammu is located in the northernmost state of India, Jammu and Kashmir. It offers undergraduate, post-graduate and doctoral programmes. It was recently ranked among A-grade universities by National Assessment \& Accreditation Council of India (2010).

Table 5.1: Type of higher education institutions in India in the academic year 2009/2010

\begin{tabular}{l|ll}
\hline Type of institutions & $\begin{array}{l}\text { Number of institutes } \\
\text { of this type in India }\end{array}$ & $\begin{array}{l}\text { University sampled } \\
\text { for the data } \\
\text { collection }\end{array}$ \\
\hline Central Universities & 40 & JNU, BHU \\
State Universities & 296 & University of Jammu \\
Institutions Deemed to be Universities & 130 & IISC \\
Institutions of National Importance & 33 & IIT \\
Institutions established through State & 5 & $/$ \\
legislation & & $/$ \\
Affiliated colleges & 25,951 & \\
\hline
\end{tabular}

Source: Ministry of Human Resource Development (Government of India) (2010); own collected data

\subsection{Selection of a sampling frame}

In preparations for the study, we conducted a pilot study among Indian students at universities that were not selected as sample universities, and among students of social sciences at JNU. The purpose of the pilot was to test whether the proposed survey instrument was appropriate. A restructured survey was delivered to students included in the final sample in a paper format and as a web-based survey. The web-based survey was sent to the list of email addresses, which we acquired from student associations and by visiting several departments. To increase the outreach to more students, we made use of email groups like yahoogroups, googlegroups and Facebook groups of concerned universities. Initially, we planned to use only web-based surveying in order to allow busy respondents to fill out the survey at a time of their convenience. Unavailability of comprehensive students' lists of email addresses as well as low initial response rate to the digital invitation to participate proved that a paper-based survey was a more appropriate method for this kind of research. At JNU, email invitations to fill out the survey were sent out to 560 collected email addresses, of which 61 replied (response rate 10.9 percent). After the circulation of paper-based surveys among students at six 
schools specialized in S\&T, we received 93 additional surveys at the same university.

In order to be eligible for the survey, students had to fulfil the following criteria. They had to be Indian, study at the selected institutions, in particular in the field of science and engineering. Because some of the students accessed the survey through group invitations (e.g. a post on a Facebook group), there were a few students in the survey who did not correspond to described criteria. 25 students could not be included in the results since they did not study at the specified universities. For the analysis, we also excluded 30 students of social sciences, humanities and law, because students from these studies were ineligible for the purposes of this study. After excluding both groups and those questionnaires that had missing entries for several preselected crucial variables, we get a total of 412 responses, which we use for the analysis.

Table 5.2 shows how questionnaires, which are used for the analysis, were collected at the selected universities. 412 students filled out the survey, among which 260 respondents filled out the paper-based survey and 152 filled out the digital one. For 62 students who filled out the survey online, we cannot identify which of the five universities they are enrolled in.

Table 5.2: Methods of collecting surveys at different universities

\begin{tabular}{llll}
\hline University & $\begin{array}{l}\text { Number of paper- } \\
\text { based surveys } \\
\text { received }\end{array}$ & $\begin{array}{l}\text { Number of } \\
\text { digital surveys } \\
\text { received }\end{array}$ & $\begin{array}{l}\text { Total number of } \\
\text { survey responses } \\
\text { received }\end{array}$ \\
\hline JNU & 90 & 55 & 145 \\
IISC & 47 & 27 & 74 \\
BHU-IT & 45 & $/$ & 45 \\
IIT Delhi & 34 & 8 & 42 \\
Jammu University & 44 & $/$ & 44 \\
Not specified & $/$ & 62 & 62 \\
\hline All universities & 260 & 152 & 412
\end{tabular}

Source: Own collected data

The survey contains separate modules for students that plan to migrate and those that do not. Students who negatively answered the first question on mobility intentions for the future were asked to answer only a limited set of questions. In addition, they are asked an additional question on reasons for preferring stay in India. The complete questionnaire is in the appendix to this chapter (Appendix 5.1).

The questionnaire has four sections. In the first section, the students are asked about their general mobility intentions, planned duration of stay abroad and reasons for the intended mobility/stay. In the second section, the students respond 
to questions on country choice. Students are asked to specify what factors about the listed countries would have to be changed so that they would choose that particular destination. In the third section, the students are asked a question on their migration history and two questions on their social network. The last set of questions is on the students' background, which covers questions on personal characteristics, university and family background.

\subsection{Summary statistics}

The survey was filled out by students at five universities. 145 students from the respondents are studying at JNU, 74 at IISc Bangalore, 45 at IT-BHU, 44 at the University of Jammu, 42 at IIT-Delhi. The other 62 students did not specify their university. Table 5.3 illustrates the respondents' characteristics along the dimensions of personal characteristics, university and family background, migration history and social network abroad. In line with the gender distribution of the targeted population of science and engineering students, our respondents comprise of predominantly male student population with 71 percent of our survey respondents being male. The average age of respondents is 24 years.

The distribution of religious belonging of students in the study is representative for the religious composition of Indian population as a whole. Respondents in the survey are predominantly Hindu (79.8 percent), followed by Muslims (6.3 percent), while Christians and Sikhs represent only a small share of the sample.

According to the quota system at Indian universities, there is a reserved percentage of positions (22.5 percent) during the admission procedure for students from scheduled castes and tribes and other "backward classes". The sample respondents have a distribution in line with this quota system, including 16.5 percent of students who belong to any of the reserved categories. The majority of our respondents are not involved in relationship and do not have children (76.9 percent and 75.4 percent, respectively).

Our survey targets students in sciences and engineering. In the complete dataset, 34.7 percent of students are currently enrolled in a programme in the field of natural sciences, 65.3 percent are in engineering studies. The dataset enables us to observe the more specific study disciplines. The students with the highest representation in the dataset are those enrolled in engineering programmes (20.7 percent of the 314 students), life sciences (20.4 percent) and computer and systems sciences (13.7 percent).

The students are distributed across all levels of study degrees, with close to one third of the respondents in each of the three levels of study programmes (26.9 
percent in Bachelors, 35.1 percent in Masters and 38 percent in PhD or Postdoctoral programmes). The majority of the students are A-grade students, representing 73 percent of the respondents. A large proportion of the students have a good command of English.

Considering the family background of the surveyed population, we observe parents' educational level, their household income, area of residence and support for student's move abroad. 52.7 percent of the students' mothers and 74.1 percent of the students' fathers have completed university education. In general, parents encourage students to move abroad. Only 35.3 percent of the students believe that their parents prefer them to stay in India. The students come from households with varying levels of income. The biggest share of students self-reported that they hail from households with low level of income (less then Rs. 25000/- per month). Approximately half ( 52 percent) of the student population originates from semiurban areas, 32.3 percent from urban metropolitan areas and the remaining 15.7 percent from rural areas.

With regard to migration history of our respondents, we observe that a vast majority does not have any international migration experience (86.3 percent). Their information about potential destination countries thus depends mainly on information they received from external sources. Only a small portion of respondents has anyone within their close family that had lived for half a year or longer outside India. However, 42.6 percent of the respondents indicates someone within an extended family lived abroad. Also among friends and colleagues, our respondents are more likely to know someone with international exposure. 51.2 percent of respondents know friends and 40.7 percent know someone professionally that lived abroad for more than half a year.

Table 5.3: Basic characteristics of the surveyed population

\begin{tabular}{|c|c|c|}
\hline & Categories & $\%$ \\
\hline \multicolumn{3}{|c|}{ Personal characteristics } \\
\hline Gender & female & 29.05 \\
\hline $\mathrm{N}=327$ & male & 70.95 \\
\hline \multirow{3}{*}{$\begin{array}{l}\text { Age } \\
N=318\end{array}$} & 22 or younger & 39.62 \\
\hline & Between 23 and 26 & 35.22 \\
\hline & 27 and older & 25.16 \\
\hline \multirow{2}{*}{$\begin{array}{l}\text { Community } \\
\mathrm{N}=302\end{array}$} & Non-Hindu communities & 20.20 \\
\hline & Hindus & 79.80 \\
\hline \multirow{2}{*}{$\begin{array}{l}\text { Reserved group } \\
N=310\end{array}$} & reserved group & 16.45 \\
\hline & non-reserved group & 83.55 \\
\hline
\end{tabular}




\begin{tabular}{|c|c|c|}
\hline $\begin{array}{l}\text { Relationship } \\
\mathrm{N}=320\end{array}$ & $\begin{array}{l}\text { single } \\
\text { relationship (boyfriend/girlfriend) } \\
\text { married }\end{array}$ & $\begin{array}{l}76.88 \\
13.13 \\
10.00\end{array}$ \\
\hline $\begin{array}{l}\text { Children } \\
\mathrm{N}=321\end{array}$ & $\begin{array}{l}\text { no children } \\
\text { children }\end{array}$ & $\begin{array}{l}75.39 \\
24.61\end{array}$ \\
\hline \multicolumn{3}{|l|}{ University characteristics } \\
\hline $\begin{array}{l}\text { University } \\
\mathrm{N}=350\end{array}$ & $\begin{array}{l}\text { JNU } \\
\text { IISC Bangalore } \\
\text { IIT Delhi } \\
\text { BHU-IT } \\
\text { Jammu }\end{array}$ & $\begin{array}{l}41.43 \\
21.14 \\
12.86 \\
12.00 \\
12.57\end{array}$ \\
\hline $\begin{array}{l}\text { Field of studies } \\
\mathrm{N}=314\end{array}$ & $\begin{array}{l}\text { natural sciences } \\
\text { engineering }\end{array}$ & $\begin{array}{l}34.71 \\
65.29\end{array}$ \\
\hline $\begin{array}{l}\text { Detailed fields of studies } \\
\mathrm{N}=314\end{array}$ & $\begin{array}{l}\text { computer and systems sciences } \\
\text { information technology } \\
\text { physics } \\
\text { math } \\
\text { life sciences } \\
\text { bio technology } \\
\text { environmental sciences } \\
\text { engineering } \\
\text { food science } \\
\text { chemistry }\end{array}$ & $\begin{array}{l}13.69 \\
7.32 \\
6.05 \\
5.41 \\
20.38 \\
9.87 \\
5.73 \\
20.70 \\
7.96 \\
2.87\end{array}$ \\
\hline $\begin{array}{l}\text { Level of studies } \\
\mathrm{N}=305\end{array}$ & $\begin{array}{l}\text { Bachelor programmes } \\
\text { Masters programmes } \\
\text { PhD and Post-Doc }\end{array}$ & $\begin{array}{l}26.89 \\
35.08 \\
38.03\end{array}$ \\
\hline $\begin{array}{l}\text { Average grade } \\
\mathrm{N}=293\end{array}$ & $\begin{array}{l}\text { Second }(B+, B, B-) \text { and third class } \\
\text { (below } C+\text { ) } \\
\text { First class }(A+, A, A-)\end{array}$ & $\begin{array}{l}26.96 \\
73.04\end{array}$ \\
\hline $\begin{array}{l}\text { Proficiency in English } \\
\mathrm{N}=317\end{array}$ & $\begin{array}{l}\text { Medium or lower (3-5) } \\
\text { Very good or good (1-2) }\end{array}$ & $\begin{array}{l}24.61 \\
75.39\end{array}$ \\
\hline \multicolumn{3}{|l|}{ Family background } \\
\hline $\begin{array}{l}\text { Mother's highest education level } \\
\mathrm{N}=315\end{array}$ & $\begin{array}{l}\text { none, or some primary } \\
\text { completed primary } \\
\text { secondary } \\
\text { vocational } \\
\text { university }\end{array}$ & $\begin{array}{l}6.98 \\
5.71 \\
28.89 \\
5.71 \\
52.70\end{array}$ \\
\hline $\begin{array}{l}\text { Father's education } \\
\mathrm{N}=316\end{array}$ & $\begin{array}{l}\text { none, or some primary } \\
\text { completed primary } \\
\text { secondary } \\
\text { vocational } \\
\text { university }\end{array}$ & $\begin{array}{l}2.22 \\
2.85 \\
13.29 \\
7.59 \\
74.05\end{array}$ \\
\hline $\begin{array}{l}\text { Support of family to move abroad } \\
\mathrm{N}=317\end{array}$ & $\begin{array}{l}\text { Encourages move } \\
\text { Prefers stay } \\
\text { Doesn't care/Neutral }\end{array}$ & $\begin{array}{l}58.68 \\
35.33 \\
5.99\end{array}$ \\
\hline
\end{tabular}




\begin{tabular}{|c|c|c|}
\hline $\begin{array}{l}\text { Average monthly income of the } \\
\text { household } \\
\mathrm{N}=314\end{array}$ & $\begin{array}{l}\text { Less thenRs. } 25000 /- \text { per month } \\
\text { Between Rs. } 25001 / \text { - and 30,000/- per } \\
\text { month } \\
\text { Between Rs. 30,001/- and 40,000/- } \\
\text { per month } \\
\text { More than Rs. } 40,000 / \text { - per month }\end{array}$ & $\begin{array}{l}40.45 \\
18.79 \\
16.24 \\
24.52\end{array}$ \\
\hline $\begin{array}{l}\text { Area of parents' residence } \\
N=319\end{array}$ & $\begin{array}{l}\text { Urban metropolitan area } \\
\text { Semi-urban, smaller cities and towns } \\
\text { Rural area }\end{array}$ & $\begin{array}{l}32.29 \\
52.04 \\
15.67\end{array}$ \\
\hline \multicolumn{3}{|l|}{ Migration history } \\
\hline $\begin{array}{l}\text { Lived abroad } \\
\mathrm{N}=371\end{array}$ & $\begin{array}{l}\text { not lived abroad } \\
\text { lived abroad }\end{array}$ & $\begin{array}{l}86.25 \\
13.75\end{array}$ \\
\hline \multicolumn{3}{|l|}{ Network abroad } \\
\hline $\begin{array}{l}\text { Parents lived abroad } \\
\mathrm{N}=289\end{array}$ & $\begin{array}{l}\text { not lived abroad } \\
\text { lived abroad }\end{array}$ & $\begin{array}{l}91.70 \\
8.30\end{array}$ \\
\hline $\begin{array}{l}\text { Brother or sisters lived abroad } \\
N=289\end{array}$ & $\begin{array}{l}\text { not lived abroad } \\
\text { lived abroad }\end{array}$ & $\begin{array}{l}82.35 \\
17.65\end{array}$ \\
\hline $\begin{array}{l}\text { Extended family abroad } \\
\mathrm{N}=293\end{array}$ & $\begin{array}{l}\text { not lived abroad } \\
\text { lived abroad }\end{array}$ & $\begin{array}{l}57.34 \\
42.66\end{array}$ \\
\hline $\begin{array}{l}\text { Friends abroad } \\
\mathrm{N}=289\end{array}$ & $\begin{array}{l}\text { not lived abroad } \\
\text { lived abroad }\end{array}$ & $\begin{array}{l}48.79 \\
51.21\end{array}$ \\
\hline $\begin{array}{l}\text { Colleagues abroad } \\
\mathrm{N}=\mathbf{2 8 5}\end{array}$ & $\begin{array}{l}\text { not lived abroad } \\
\text { lived abroad }\end{array}$ & $\begin{array}{l}59.30 \\
40.70\end{array}$ \\
\hline
\end{tabular}

\subsection{Qualitative research approach}

Aiming to capture richness of information, we conducted qualitative interviews with 35 students at the mentioned universities to complement the survey analysis. Most interviews took place at JNU in New Delhi and IISC in Bangalore (13 and 15, respectively) and we interviewed 4 people at BHU-IT and 3 at IIT Delhi. Our initial contact persons at the respective universities were either professors or administration personnel who brought us in contact with students. To increase the understanding of determinants of international migration, we included students with plans to move abroad in the future as well as students who planned to stay in India. In order to examine what drives people to migrate, we oversampled students with migration intentions. In total, 29 of our respondents planned to move abroad and the remaining 6 were unsure about it or did not have such plans. Apart from 9 women, the majority of students in the sample are male (26), which is consistent with the gender distribution of the target population. We include students enrolled in different levels of education, from Bachelor's to PhD level. 
Each interview was started with a narrative question on their future plans: "Could you tell me what your future plans are? Do you have plans on moving abroad in the near future? What is the reason for such decision?" We formulated a broad question in order to elicit the interviewee's main narrative on the reasons for going abroad or not. Moving abroad is specified as the central theme of the interview and is set in the context of plans for the future (Flick, 2006). The rest of the interview was organized in a semi-structured way. Students were asked about their family and university background, migration history, social networks, professional opportunities in India and abroad, quality of life and public services, barriers for migration and finally, and about the role of immigration policy in the decisionmaking process concerning migration. The interviews were conducted in the same time period the survey took place, in March and April 2009 at JNU and BHU-IT and in August 2009 at IISc Bangalore and IIT Delhi. All interviews were conducted in English. They were recorded and fully transcribed.

In addition to interviewing students about their future migration plans, we interviewed experts with particular knowledge on international migration from Indian universities. The experts served as initial contact points as well as key informants for understanding the context of this case study. We interviewed professors who work at respective universities. They were selected either because of their expertise on Indian international migration or because they are in regular contact with the students. We also interviewed Malini Sen, a journalist at 'The Times of India', who covers the section on education in the journal.

In our analysis in chapter six and seven, we use the qualitative data to elaborate on issues that remain unclear or contradict common expectations in the quantitative analysis. The interviews should thus be considered as complementary to the survey analysis, and not considered as separate research approach. The purpose of using mixed methods is to increase validity of the final findings.

\subsection{Research questions and hypotheses}

The case study addresses the following issues:

1. What are the determinants to move abroad, and what determines the chosen destinations? In more detail, what are the important personal and structural background factors and expectancy-based perceptions of place utility that determine general intentions to move abroad and destination-specific migration intentions? 
2. Are the determinants of migration to continental Europe different from determinants of migration to the Anglo-Saxon countries (UK, Canada and Australia) or to the United States?

It should be stressed that the case study of Indian students observes their intentions to move and not the actual move itself, as no one in the study sample actually moved yet. Research on international migration increasingly uses the method of asking people to state their intentions instead of observing their actual movements (De Jong, 2000; Frieze et al., 2004; Liebig \& Souza-Poza, 2004; Van Dalen, Groenewold, \& Schoorl, 2005). There is an established practice in social psychology to use the theory of planned behaviour or the related theory of reasoned action (Ajzen, 2000; Ajzen \& Fishbein, 1980). Despite some doubtful views on the utilization of stated preferences as guides to eventual behaviour (Constant \& Massey, 2002), a few studies which looked at intentions as well as at the consequent behaviour suggest that intentions are good predictors of future migration (De Jong, 2000; De Jong, Davis Root, Gardner, Fawcett, \& Abad, 1985; Gardner, De Jong, Arnold, \& Carino, 1985; Lu, 1999; Van Dalen, Groenewold, \& Fokkema, 2005; Van Dalen \& Henkens, 2008). Nevertheless, even though international student mobility and highly-skilled mobility have become considerably more accessible, there are still several barriers which prospective migrants have to surmount before the actual move. They need resources to finance the move and overcome several formal barriers, such as obtaining residence and work permits. For various obstacles not all mobility plans turn into actual behaviour. Having this in mind, we want to highlight that the succeeding two chapters, at the outset, tackle the issue of international mobility from the perspective of intentions and subsequently address the question on what might cause gaps between plans and the actual behaviour. The actual move of these students remains to be explored.

Chapter 6 looks at the factors influencing the plans to move abroad or not. We test the hypotheses regarding the determinants of student mobility as explained below for each of the observed factors. Table 5.5 in the appendix present the theoretical basis for variable selection, including the hypotheses for the effect of each of the included variables on the likelihood of mobility. Chapter 7 further looks at the factors influencing preferred destination choice for future migration by looking more in depth in decision making of those students who responded that they will move abroad. 


\subsubsection{Personal characteristics}

When reviewing personal characteristics, we consider the way age, gender, belonging to a certain community and reserved group, relationship status, and area of residence (rural/urban) affect the intention to move abroad. We assume that the included personal characteristics might affect the propensity for moving abroad in several ways. The likelihood of migration is expected to increase with age (Gibson \& McKenzie, 2009). Migration channels are also shown to be gendered, with women moving under different circumstances (Kofman, 2000). Because of different gender roles, emigration might be sex-selective (Pedraza, 1991), and the common expectation is that men are more likely to migrate than women. Contrary to general expectations, the datasets documenting the gender structure of skilled migration suggest that skilled women exhibit higher emigration rates than skilled men (Docquier, Lowell, \& Marfouk, 2007; Dumont, Martin, \& Spielvogel, 2007; Faggian, MCCann, \& Sheppeard, 2007). Such gender imbalance could be related to some kind of discrimination in the labour market in the country of origin (Faggian et al., 2007). However, looking specifically at the Indian student population, we expect that men are more likely to plan moving abroad. Proportions of women studying abroad differ from country to country. While, for instance, in East Asia and the Pacific the female share of mobile students is higher compared to the female share of domestic students, this is not the case for South Asian countries. In India, women account for 39 percent of student population and only for 27 percent of internationally mobile students (UNESCO-IUS, 2010a). Gender may also predict the country choice as it was shown in the paper by Constant and D'Agosto (2008). Looking at the determinants of country choice for Italian scientists and researchers, they find that men are less likely to go to the UK than women.

Discrimination in the home country environment, in the labour market as well as in the society at large, leads us to expect overrepresentation of minority groups among people who intend to move abroad. People with a non-Hindu background or from a reserved group might find it more difficult to find a good job in India despite high qualifications. Moving abroad can be used as a compensation mechanism for a lack of good options in a home country. By migrating, non-Hindu Indians can become part of a different system, in which their minority status and religion would become less relevant.

We expect people in relationships to be less prone to move abroad since they are likely to take into account partnering issues (Guth, 2007; Koser \& Salt, 1997; Smith, 2004). Since most decisions on migration take place within a household, an individual engaged in a relationship first has to solve family issues and see whether migration is a viable option also for other family members. Such considerations 
might decrease the chance of migrating, if the household members are less interested in moving, or might influence the choice of location. De Grip, Fouarge, and Sauermann (2009) found that European science and engineering graduates who are in relationships are more likely to migrate to another European country than to an Anglo-Saxon country. However, families can also induce mobility in a sense that they "provide emotional support and encouragement in addition to needed assistance in day-to-day life" (Guth, 2007: 5), while living abroad.

\subsubsection{Family background}

As previously stated, a migration decision is not made only by potential migrants. The New Economics of Labour Migration (Stark \& Bloom, 1985) emphasises the role of social factors in migration decisions and treats the household as the decisionmaking unit, in particular for people from developing countries. In most migration studies, social networks are celebrated as playing a facilitating influence in migration processes, however, with excessive claims on group members and with restrictions on their individual freedom, families may also undermine individual economic initiatives (De Haas, 2010). We include the family background in this analysis by observing the effects of parental education, parental residence, household income, and family support on the intention of moving abroad. The assumption is that students from a higher socio-economic background will be more likely to move abroad since highly educated parents tend to be more encouraging for students to move abroad. Parental education is strongly associated with educational outcomes (Checchi, 2006; Tacsir, 2010; Xia, 2010), therefore we also expect links with mobility for education. Likewise, wealthier families can easier afford the costs of moving abroad (Gibson \& McKenzie, 2009). However, as stated by Gibson and McKenzie, students with a wealthier background may also have better income opportunities in their home countries as their families have better social networks for arranging well-paid jobs, so the effect of families' wealth is not straightforward. With respect to parental residence, we expect people from urban areas to be less likely to plan moving abroad because of better local opportunities as compared to people in the rural areas.

\subsubsection{University-related factors}

The third set of variables we consider are related to the educational background of students. In the study, we test whether the field of studies, level of studies, their average grade, and level of English affect the intentions of moving abroad. Transaction of human capital depends largely on the types and level of skills. Skills in technology-intensive sectors have a much more global character and are more easily transferable across different countries than, for instance, skills and 
knowledge in social sciences. Gibson and McKenzie (2009) find a strong positive association between studying foreign languages or science subjects in secondary school and consequent migration. In our sample, we expect students which specialize in natural sciences to be more prone to migration than students in engineering due to better career prospect in India. Similar to results in the test of educational selectivity by Gibson and McKenzie (2009) we also anticipate that students with a higher educational degree want to move abroad more often than students with a lower level of education. We expect students that are enrolled in PhD or Post-doctoral programmes to be more likely to plan their moves abroad than students enrolled in Masters or Bachelors programmes. Likewise, high average grades and proficiency in English are also expected to positively influence the wish to move abroad (De Grip et al., 2009). All expectations are in line with the human capital theory, which presupposes that people with mentioned characteristics can expect higher returns upon migration and will thus self-select themselves to move abroad.

\subsubsection{Migration history}

In line with King, Ruiz-Gelices \& Findlay (2004), we expect that past experiences in working or studying abroad will increase the chance of migrating in the future. Experiences with mobility enhance the information available and hence reduce the cost and risks of future mobility as well as facilitate adaptation. Parey and Waldinger (2008) and de Grip et al. (2009) find that studying abroad significantly increases individual's probability of working in a foreign country. Likewise, students in the Pacific region who have taken two or more trips abroad during secondary school have a higher incidence of migration (Gibson \& McKenzie, 2009).

\subsubsection{Network abroad}

Besides having personal experiences with international migration, students can get information about mobility opportunities from external sources. Network effects provide an explanation why an existing migrant population in a host country works as a positive pull factor for future inflows. They can facilitate migration by reducing costs and risks and at the same time, strengthen migration aspirations. There is compelling evidence on the relevance of social networks of previous migrants (Clark et al., 2002; Gross, 2006; Mitchell \& Pain, 2003). Parents, the closest social network, are considered highly influential. De Grip et al. (2009) find a positive effect of the migration background of the parents on migration of students after their graduation. In addition to close family ties, networks may exist through other channels, such as weaker family ties and friends, people belonging to the same professional groups or people from the same ethnic community. We distinguish 
between the role of stronger and weaker social ties in migration process. Weak ties act as bridges between primary groups so it is more likely that new information and opportunities will enter groups through them (Granovetter, 1973). We ask students in the survey whether any of their family members, friends or professional colleagues live or have lived abroad in the past. The hypothesis is that people who have a network abroad will have an easier access to information and will be more likely to move.

\subsubsection{Individual perception of importance of factors}

Keeping in mind the explanatory limitations of the mentioned factors and realizing that they do not cover all events that can trigger the migration decisions, other reasons are used to understand the migration flows. As many factors behind the migration decision otherwise cannot be captured in data, we observe in what way preferences for working places, lifestyle and the like might help us explain the intentions. Students were asked to indicate the importance of the named factors for the place where they want to live and their expectations for alternative countries of destination regarding the likelihood for achieving the named qualities. We compiled a list of 26 factors in the field of work, local environment (amenities), social contact, and public services. The named qualities were chosen on the basis of theories on migration determinants and previous empirical research on determinants of location choice as presented in Table 5.5 in the appendix. Especially aspects emphasized by the New Economics of Labour Migration and amenities literature are hardly ever included in studies on migration decisions. By including them, we see whether students choose to go abroad or stay in their home country for other reasons concerning their quality of life.

Better possibilities for career advancement in highly developed countries as compared to their home countries correspond to the often cited professional aspects as the main motivation for moving abroad (Gibson \& McKenzie, 2009; Körner, 1999). Science and engineering workers, in particular, have been proven to place less importance to the pecuniary aspects of their jobs (De Graaf, Heyma, \& Van Klaveren, 2007; De Grip et al., 2009) and are more likely to migrate to a place with a higher R\&D intensity where they can be better involved in innovative work. On the other hand, importance of family and friends, cultural, lifestyle factors work as a 'keep' factor in a home country (Gibson \& McKenzie, 2009; Mahmood \& Schömann, 2003b; van der Velde \& van Naerssen, 2007). At the same time, some conditions in receiving countries seem unfavourable and work as 'repel' factors for migration (van der Velde \& van Naerssen, 2007). Perceptions of target countries, such as discrimination towards foreigners, language barriers or public safety might 
deter people from moving abroad. Our hypothesis is, therefore, that people who value work-related factors higher will more likely plan to move abroad, while people who value local environment, social contacts and public services will prefer staying in India.

\subsection{Concluding remarks}

This chapter sought to present the methodology followed in the Indian case study, which was utilized for studying migration aspirations of students in selected highquality universities. Student mobility can be considered as an integral part of migration decisions, embedded in a "context of transition from the local to the global, and the momentous opening up of spaces for communication, where mobility is conceived as a continuous and multiples process rather than as a oneway ticket" (Murphy-Lejeune, 2002). Several recent studies show the link between student mobility and subsequent migration (De Grip et al., 2009; Findlay, Stam, King, \& Ruiz-Gelices, 2005; Li et al., 1996; Parey \& Waldinger, 2008; Wiers-Jenssen, 2008) and it is in this viewpoint that student migration is interpreted as a form of knowledge migration by academic research as well as by policy makers which increasingly treat student migration as a form of global talent recruitment. Having in mind the obstacles which prevent some students from planning international move, we look not only at the socio-demographic profile of students but also at students' background in terms of their social and economic context. As the choice of potential migrants cannot be seen as the ultimate explanation of the move (Findlay, 2010), it is essential to recognize the significance of their family background, academic records and existing international exposure, either from their first- hand experience or from migration networks. The main concern of the presented case study, which is explained in detail in the subsequent two chapters, is to understand the forces which shape the geography of Indian students in the field of sciences and engineering. To avoid favouring the explanation of geographies of international student mobilities solely by social demand theories, we also look at the situation of the global higher education market as well as the existing geography of highly-skilled migration in general. It is clear that not all aspiring migrants achieve entry into the country of their first choice because of restriction on the side of universities or companies. However, we here observe the unfolding of migration decisions which is paramount for a better understaning of migration process. First, we look at the motivations of students and the way they perceive their family expectations, which corresponds to the demand-side approaches. Second, we embed the migration decision-making in the environment of supply-side policies and institutions. With a particular interest in attractiveness of continental European countries in the global higher education and labour 
market, we set students' perceptions of specific countries against the actual situation and our earlier policy analysis. The design of survey instruments was based on the situation of migration policies in the period of data collection. It is possible that perception of countries has changed with recent policy adaptations, however continental European countries, except the UK, remained on a similar trend of opening up to third-country national. As demonstrated in Chapter 3, European migration policies have become progressively more favourable towards the admission of highly-skilled workers and are in particular active in changing rules for young migrants and former students to transition to the labour market and contribute to the knowledge economy. Such conditions would matter especially for those students planning to stay abroad after their studies. Subsequent analysis of migration aspirations, among others, addresses the question whether supply-side practices from the side of governments and from higher education institutions to bring in young talent resonate with potential movers and in that way reshape the geography of skilled mobility from India. 


\subsection{Appendices}

\section{Appendix 5.1: Questionnaire form}

1. Are you considering moving abroad?

a) Yes

b) No

If you answered yes to the above question, please answer all below questions in this questionnaire.

If you are not considering moving abroad, please answer only question 2 and other questions with an asterisk $(*)$.

2. * (only for the ones that are NOT considering moving abroad)

How important do you consider the following REASONS for making you want to stay in India? Please indicate, on a scale from 1-5, the importance for each of the reasons for staying. Please indicate by ticking the appropriate box with an X. Answer for each category.

$1=$ not important at all

$2=$ somewhat unimportant

$3=$ neutral

4=somewhat important

$5=$ very important

$\begin{array}{lllll}1 & 2 & 3 & 4 & 5\end{array}$

I want to stay near my family and friends

I want my children to grow up in India

I would have difficulties adapting to a different culture

It is difficult to get accepted to universities abroad

It is difficult to find a job abroad

My educational/professional qualifications would not be recognized

It is difficult to obtain a residence and work permit

My level of English is not good enough

I can get a good position in India

I think educated people should stay in India

I think that the quality of my life can be better in India

As a foreigner I would not get the same respect as the natives

I want to work for the benefit of India

I can't afford financially to move abroad

The procedures for moving abroad are too difficult 
3. What destinations would you consider if you move abroad? You may choose as many options as you want. (Answer only if you are considering moving abroad)
a) USA
b) Australia
c) Canada
d) United Kingdom
e) another European country, namely
f) to another country, namely (specify, can be more than one)
g) I want to move abroad, but I don't know yet where to.

4. What would be your top destination country in case you want to move in the following 5 years? (Answer only if you are considering moving abroad)

5. For each of the countries below, if they are not already your top destination country, please indicate what factors about this country would have to be altered in order for you to select this destination (either for work or study). Please, write a short explanation for each of the countries below. (Answer only if you are considering moving abroad)
a) UK
b) USA
c) Germany
d) The Netherlands

6. How long would you expect to stay in the chosen destination country? (Answer only if you are considering moving abroad)

_ _ years

7. If you would like to move abroad, what is the main reason for this? Choose one answer. (Answer only if you are considering moving abroad)
a) education, studying
b) work-related
c) accompanying my family
d) travelling/tourism
e) other - specify

8. How important do you consider the following REASONS for you to move to another country? Please indicate, on a scale from 1-5, the importance for each of the reasons for moving. Please indicate by ticking the appropriate box with an X. Answer for each category. (Answer only if you are considering moving abroad)

$1=$ not important at all

$2=$ somewhat unimportant

$3=$ neutral

4=somewhat important

$5=$ very important 
pursuing further studies

better research facilities abroad

better career perspectives

higher income opportunities

attractive working conditions

obtaining international experience

lack of research funds in India

lack of working possibilities in India

meeting new people

different social norms/pressures abroad

accompanying a family member

better local environment and amenities

public safety and crime

better social security and benefits (pensions, unemployment benefits...)

other - specify reasons

9. * Have you ever lived outside India staying in one location for one month or longer? If yes, please specify for each period of your stay abroad, in which country you lived, length and a reason for your stay. (Everyone should answer this question)

a) No

b) Yes

\begin{tabular}{|c|c|c|c|}
\hline & Country & $\begin{array}{l}\text { Duration of stay } \\
\text { (number of } \\
\text { months) }\end{array}$ & $\begin{array}{l}\text { Reason of stay } \\
\text { (choose one option) }\end{array}$ \\
\hline $\begin{array}{l}\text { 1st time } \\
\text { abroad }\end{array}$ & $\begin{array}{l}\text { I was in } \\
\text { (specify a } \\
\text { country) }\end{array}$ & for ___ months & $\begin{array}{l}\text { a) education, study-related } \\
\text { b) work-related } \\
\text { c) accompanying my family } \\
\text { d) travelling/tourism } \\
\text { e) other - specify }\end{array}$ \\
\hline $\begin{array}{l}2^{\text {nd }} \text { time } \\
\text { abroad }\end{array}$ & $\begin{array}{l}\text { I was in } \\
\text { (specify a } \\
\text { country) }\end{array}$ & for ___ months & $\begin{array}{l}\text { a) education, study-related } \\
\text { b) work-related } \\
\text { c) accompanying my family } \\
\text { d) travelling/tourism } \\
\text { e) other - specify }\end{array}$ \\
\hline
\end{tabular}

10. How important do you consider the presence of the following characteristics/facilities in a country where you want to live? Answer for each category. Please indicate on a scale from 1-5 by ticking the appropriate box with an $X$. (Everyone should answer this question)

$$
\begin{aligned}
& 1=\text { not important at all } \\
& 2=\text { somewhat unimportant } \\
& 3=\text { neutral } \\
& 4=\text { somewhat important } \\
& 5=\text { very important }
\end{aligned}
$$


high demand for my qualifications

easily finding a suitable job after my studies

attractive salary

quality and content of my work

good research facilities in companies and public institutions

no more than 8-hour working days

career progression opportunities

recognition of educational/professional qualifications

job security (not easy for employers to fire workers)

Local environment

costs of living

family-friendly environment

good quality of higher education institutions

multicultural environment

rich cultural institutions (museum, theatre, cinema...)

public safety

political stability, stable government

economic stability

social equality among population

Social contacts

Friendly, hospitable population

not feeling discriminated

English commonly spoken

no need to learn a new language

having high social status

\section{Public services}

attractive taxation system

quality and access to medical services (hospitals, family doctor)

social security and benefits (such as unemployment benefits, pensions)

11. * For each of the countries listed in the table indicate your expectations regarding how likely it is that you can achieve the named qualities. Answer for all countries and for all categories. (Everyone should answer this question)

Please, indicate on the scale from 1-5:

$1=$ very unlikely

$2=$ somewhat unlikely

$3=$ don't know/neutral

$4=$ somewhat likely

$5=$ very likely

Example: The following example shows how you should mark the chosen category in case you believe that it is somewhat unlikely that you can easily find a suitable job India and the USA (mark 2), very likely that you can easily find a suitable job in the UK and in the Netherlands (mark 5), and that you do not know about the situation in Germany (mark 3). 
Please, fill in the table for each of the countries and for all categories.

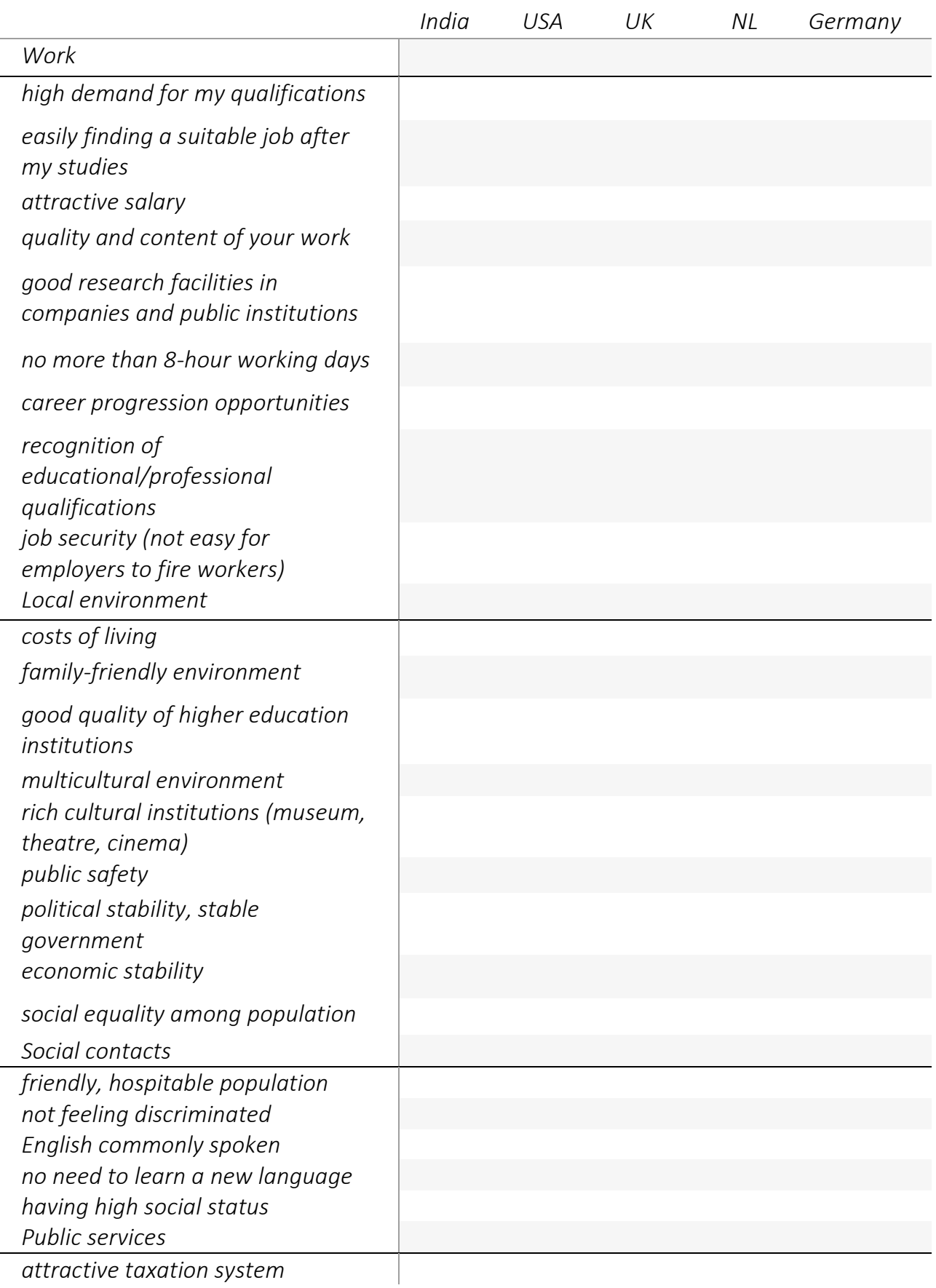


quality and access to medical

services (hospitals, family doctor)

social security and benefits (such

as unemployment benefits,

pensions)

12.* Have any of the below named persons lived abroad for half a year or more? If yes, specify a country where they have lived. (Everyone should answer this question)

No Yes Where? Specify a country/countries

\section{Parents}

Brothers or sisters

Extended family (f.e. aunts, uncles)

Close friends

People in my profession which I

know personally

13. * How does your family feel about your potential move abroad? (Everyone should answer this question)
a) Strongly encourages move
b) Somewhat encourages move
c) Prefers stay
d) Strongly prefers stay
e) Doesn't care

14. What kind of financial resources would you use for moving abroad? More than one answer is possible. (Answer only if you are considering moving abroad)
a) fellowship
b) a loan
c) family's financial support
d) my own savings
e) other, specify

15. How important do you consider the following aspects for your prospective host country? Please indicate, on a scale from 1-5, the importance for each of the below named aspects. Please indicate by ticking the appropriate box. (Answer only if you are considering moving abroad).

$1=$ not important at all

$2=$ somewhat unimportant

$3=$ don't know/neutral

4=somewhat important

$5=$ very important 
Easily bringing in my family now or later

That I can easily return to later in my career

Living near a large Indian community

Clear application procedure for a residence and work permit

Accessibility of your spouse to the labour market

Being able to stay in a country longer than 5 years

Possibility of permanent settlement

Possibility of acquiring local citizenship

* YOUR BACKGROUND (Everyone should answer this section)

16.* Gender
a) male
b) female

17. * Year of birth?

19

18. * Please, state the field of your studies. Choose one answer.
a) Computer and systems sciences
b) Information technology
c) Physical sciences
d) Mathematics
e) Life Sciences
f) Biotechnology
g) Environmental sciences
h) Social sciences
i) Humanities
j) Other, specify

19. * In which level of educational programme are you currently enrolled?
a) BTech
b) $\mathrm{MA}$
c) $\mathrm{MSc}$
d) Mtech
e) Mphil
f) $\mathrm{PhD}$

20. * In which year of your current educational programme are you?
a) first
b) second
c) third
d) fourth
e) other 
21. * What is your average grade in the running year?
a) First class (A+, A. A-)
b) Second class $(B+, B, B-)$
c) Third class (below $\mathrm{C}+$ )

22. * What is your proficiency in English?
a) Very good
b) Good
c) Medium
d) Bad
e) Very bad

23. * What is the highest educational level achieved by your mother?
a) none, or some primary
b) completed primary
c) secondary
d) vocational
e) university

24. * What is the highest educational level achieved by your father?
a) none, or some primary
b) completed primary
c) secondary
d) vocational
e) university

25.* Which community do you belong to?
a) Hindu
b) Sikh
c) Muslim
d) Buddhist
e) Jain
f) Christian
g) Other, specify

26. * Do you belong to a reserved group?
a) No
b) Yes, (which?) a) SC b) ST c) OBC

27.* Which part of India do you come from (your parents' residence)?

a) Urban metropolitan area

b) Semi-urban, smaller cities and towns

c) Rural area

28. * In which state do your parents live currently? 
29.* What is the average monthly income of your household per month?
a) Less then Rs. 25000/- per month
b) Between Rs. 25001/- and 30,000/- per month
c) Between Rs. 30,001/- and 40,000/- per month
d) More than Rs. 40,000/- per month

30. ${ }^{*}$ What is your present relationship status?
a) single
b) in a relationship (boyfriend/ girlfriend)
c) married
d) separated/divorced

31. * Do you have children?

a) Yes, ___ (how many?)

b) No

You have reached the end of the questionnaire.

Thank you very much for your cooperation! 
Table 5.4: Questionnaire development on the basis of theory

\begin{tabular}{|c|c|c|c|}
\hline Question in the survey & $\begin{array}{l}\text { Hypotheses } \\
\text { The likelihood of } \\
\text { mobility is higher for: }\end{array}$ & $\begin{array}{l}\text { Theoretical } \\
\text { basis }\end{array}$ & $\begin{array}{l}\text { Determinants } \\
\text { of migration }\end{array}$ \\
\hline $\begin{array}{l}\text { Personal characteristics } \\
\text { Q14: Gender } \\
\text { Q15: Age } \\
\text { Q23: Which community do } \\
\text { you belong to? } \\
\text { Q24: Do you belong to a } \\
\text { reserved group? } \\
\text { Q28: What is your present } \\
\text { relationship status? }\end{array}$ & $\begin{array}{l}\text { men } \\
\text { older people } \\
\text { people with a non- } \\
\text { Hindu background } \\
\text { people from a reserved } \\
\text { group } \\
\text { single people }\end{array}$ & $\begin{array}{l}\text { The human } \\
\text { capital theory }\end{array}$ & \multirow[t]{2}{*}{$\begin{array}{l}\text { Future } \\
\text { expectations of } \\
\text { migrants based } \\
\text { on their } \\
\text { personal } \\
\text { characteristics }\end{array}$} \\
\hline $\begin{array}{l}\text { University-related factors } \\
\text { Q16: Please, state your field } \\
\text { of studies. } \\
\text { Q17: In which level of } \\
\text { educational programme are } \\
\text { you currently enrolled? } \\
\text { Q19: What is your average } \\
\text { grade in the running year? } \\
\text { Q20: What is your } \\
\text { proficiency in English? }\end{array}$ & $\begin{array}{l}\text { students in natural } \\
\text { sciences } \\
\text { students in higher level } \\
\text { of studies } \\
\text { students with high } \\
\text { average grades } \\
\text { students with good } \\
\text { knowledge of English }\end{array}$ & $\begin{array}{l}\text { The New } \\
\text { Economics of } \\
\text { Labour } \\
\text { Migration }\end{array}$ & \\
\hline $\begin{array}{l}\text { Family background } \\
\text { Q } 11 \text { How does your family } \\
\text { feel about your potential } \\
\text { move abroad? } \\
\text { Q21/22: What is the highest } \\
\text { educational level achieved } \\
\text { by your mother/father? } \\
\text { Q25: Which part of India do } \\
\text { you come from (your } \\
\text { parents' residence)? } \\
\text { Q27: What is the average } \\
\text { monthly income of your } \\
\text { household per month? }\end{array}$ & $\begin{array}{l}\text { people who get support } \\
\text { from their families } \\
\text { people whose parents } \\
\text { have high level of } \\
\text { education } \\
\text { people from semi- } \\
\text { urban and rural areas } \\
\text { for students from high- } \\
\text { income families }\end{array}$ & $\begin{array}{l}\text { The theory of } \\
\text { economics of } \\
\text { family } \\
\text { migration }\end{array}$ & $\begin{array}{l}\text { Risk sharing } \\
\text { among family } \\
\text { members } \\
\text { Utility gains for } \\
\text { all family } \\
\text { members }\end{array}$ \\
\hline $\begin{array}{l}\text { Migration history } \\
\text { Q7: Have you ever lived } \\
\text { outside India staying in one } \\
\text { location for one month or } \\
\text { longer? }\end{array}$ & $\begin{array}{l}\text { people who have past } \\
\text { experiences with living } \\
\text { abroad }\end{array}$ & \multirow[t]{2}{*}{$\begin{array}{l}\text { Migration } \\
\text { network } \\
\text { theory }\end{array}$} & \multirow[t]{2}{*}{$\begin{array}{l}\text { Presence of } \\
\text { social networks } \\
\text { abroad }\end{array}$} \\
\hline $\begin{array}{l}\text { Network abroad } \\
\text { Q10: Have any of the below } \\
\text { named persons lived abroad } \\
\text { for half a year or more? } \\
\text { (parents, brothers or sisters, } \\
\text { extended family, close } \\
\text { friends, people in your } \\
\text { profession) }\end{array}$ & $\begin{array}{l}\text { people who have a } \\
\text { social network abroad }\end{array}$ & & \\
\hline
\end{tabular}


Table 5.5: Theories as a basis for selection of factors of importance for location choice

\begin{tabular}{|c|c|c|}
\hline $\begin{array}{l}\text { Theory of } \\
\text { determinants }\end{array}$ & Determinants & Factors of importance for location choice \\
\hline $\begin{array}{l}\text { The neoclassical } \\
\text { theory of } \\
\text { migration }\end{array}$ & Higher wage levels & \multirow{2}{*}{$\begin{array}{l}\text { - } \text { high demand for my qualifications } \\
\text { - } \text { easily finding a suitable job after my studies } \\
\text { - } \text { attractive salary } \\
\text { - } \text { quality and content of my work } \\
\text { good research facilities in companies and } \\
\text { - public institutions } \\
\text { - } \text { good quality of higher education institutions }\end{array}$} \\
\hline $\begin{array}{l}\text { The human } \\
\text { capital theory }\end{array}$ & $\begin{array}{l}\text { Future expectations } \\
\text { of migrants based on } \\
\text { their personal } \\
\text { characteristics }\end{array}$ & \\
\hline $\begin{array}{l}\text { The theory of } \\
\text { economics of } \\
\text { family } \\
\text { migration }\end{array}$ & $\begin{array}{l}\text { Utility gains for all } \\
\text { family members }\end{array}$ & - family-friendly environment \\
\hline $\begin{array}{l}\text { The New } \\
\text { Economics of } \\
\text { Labour } \\
\text { Migration }\end{array}$ & $\begin{array}{l}\text { Risk sharing among } \\
\text { family members } \\
\text { Transaction costs }\end{array}$ & $\begin{array}{l}\text { - } \text { recognition of educational/professional } \\
\text { - } \text { qualifications } \\
\text { - } \text { workecrs) } \\
\text { - } \text { economic stability } \\
\text { - } \text { quality and access to medical services } \\
\text { (hospitals, family doctor) } \\
\text { - } \quad \text { social security and benefits (such as } \\
\text { unemployment benefits, pensions) } \\
\end{array}$ \\
\hline $\begin{array}{l}\text { Amenities } \\
\text { literature }\end{array}$ & $\begin{array}{l}\text { Attractive local } \\
\text { environment } \\
\text { Tolerant atmosphere }\end{array}$ & $\begin{array}{l}\text { - } \text { no more than 8-hour working day } \\
\text { - } \text { cost of living } \\
\text { - } \text { social equality among population } \\
\text { - multicultural environment } \\
\text { - } \text { rich cultural institutions } \\
\text { - public safety } \\
\text { - political stability, stable government } \\
\text { - friendly, hospitable population } \\
\text { - not-feeling discriminated }\end{array}$ \\
\hline $\begin{array}{l}\text { Migrant self- } \\
\text { selection }\end{array}$ & $\begin{array}{l}\text { Progressive return to } \\
\text { skills }\end{array}$ & $\begin{array}{l}\text { - having high social status } \\
\text { - } \text { attractive taxation system }\end{array}$ \\
\hline $\begin{array}{l}\text { Structural } \\
\text { theories }\end{array}$ & $\begin{array}{l}\text { Historical, cultural, } \\
\text { colonial and } \\
\text { technological linkages } \\
\text { between countries }\end{array}$ & - English commonly spoken \\
\hline
\end{tabular}




\section{Determinants of international mobility decision: The Case-Study of India ${ }^{51}$}

\subsection{Introduction}

Students are increasingly interested in spending at least part of higher education abroad. 4.3 million tertiary students were enrolled in a higher education institution outside their country of origin in 2011. The numbers of internationally mobile students are increasing at a fast pace, with more than a threefold increase from 1990 (1.3 million) to 2011 (OECD, 2013a). This is not surprising, given the large benefits that are attached to studying abroad for the student. Students can benefit from study provisions on a higher level of quality or in the field of specialization which is not available in their home country. International educational experience is also considered an important attribute of intercultural competence. The present global environment highly values people with international experience and associated global cultural skills which creates a further need for students to seek higher education opportunities abroad, preferably at highly reputed institutions (Cant, 2004; Cubilo, Sanchez, \& Cervino, 2006; Shaftel, Shaftel, \& Ahluwalia, 2007). Studying abroad is perceived by individuals as a boost to their career in their home country as well as on the international job market.

Often, studying abroad is considered a stepping stone towards migration in the future (Vincent-Lancrin, 2008). Foreign students, especially those from developing countries, demonstrate high stay rates in a host country after the graduation (Finn, 2003; Hein \& Plesch, 2008; Rosenzweig, 2006). A degree obtained in a host country's institution is often considered as an investment towards finding a job after the graduation either in the host country or in a third country. Next to the benefits in terms of greater international recognition, many host countries reward degrees obtained in their country by allowing students to stay in the country after their studies and treating them favourably when applying for a residence permit.

Simultaneously with the increased interest of individuals in higher education, new competitors are entering the global competition for talents, attempting to attract their shares of international students. Competition is played out among a growing number of educational institutions and is increasingly expanding also to the national governments. Governments are involved in the competition for foreign

\footnotetext{
${ }^{51}$ Paper available as; Hercog, M. \& Van de Laar, M. (2013). Determinants of international mobility decision:

The case-study of India. UNU-MERIT Working Paper Series 2013-067.
} 
students through active promotion strategies and through targeted immigration policies. Many industrialized countries are changing their policies to become more attractive for highly-skilled migrants, with enhancement of student mobility as one of the mechanisms to achieve this goal. Easy and transparent access to visas, possibility to work while studying, and extended job-searching periods after graduation are among the policy measures introduced to attract international students, who might then potentially move into the labour market of the host country.

Faced with a situation in which countries compete for international students, it becomes especially important to understand students' preferences regarding migration behaviour. This is important for all actors involved in international higher education, including educational institutions, governments and employers in receiving as well as in sending countries. Knowledge of decisive factors for mobility helps competitors for highly-skilled migrants in attracting people, and contributes to understanding why certain countries attract dominant shares of foreign students while other countries, in spite of increased efforts to attract students, have not been so successful.

Chapter 6 uses the collected data from the survey held among students at five Indian universities to describe and analyse the decision-making about moving abroad in the future. In total, 412 students in science and engineering fields participated in our survey, answering sets of questions on their personal situation, their preferences to move abroad and their social networks. Of those 412 students, 262 indicated to have an interest to move abroad, and 150 indicated no desire to leave India. ${ }^{52}$ The survey data were complemented with qualitative data, obtained during interviews in India.

The main objective of the chapter is to observe the factors which influence the decision to either stay in India or move abroad. Firstly, we offer a brief historical account of migration from India with an emphasis on student mobility. The chapter continues with a descriptive analysis of collected data at five Indian universities and observes whether there are any characteristic differences between those students who plan to move abroad compared to those that do not have such plans. In the third section, we identify which factors influence the decision on moving abroad by using logistic regression analysis. The last section reflects on the results of the quantitative analysis, supporting it with results from the qualitative study.

\footnotetext{
52 Detailed information on the survey is included in Chapter 5.
} 


\subsection{Emigration from India}

India has been an important emigration country since the early $19^{\text {th }}$ century and represents one of the most established historical diaspora groups. With an estimated 25 million people in 189 countries around the world, Indians abroad constitute the second largest migrant community in the world (after China) (Castles, 2008; MOIA, 2010). With early roots in British colonial history, India acted as a source country for migrant labour for centuries. Indian labourers were sent to British colony plantations in the Caribbean, the Indian Ocean, North and South east Asia, Africa and the Pacific to supply labour between the $16^{\text {th }}$ an $18^{\text {th }}$ century (Khadria, 2009). Particularly after slavery was abolished in the British Empire in 1834 , there was a need for large scale labour recruitment in the Atlantic, Pacific and the Indian Oceans (MOIA, 2010). The Indian migrants were recruited mainly in the form of indentured labour and later on within the 'kangani'53 system creating the base of the old Indian diaspora. It is estimated that between 1834 and 1947, 30 million Indians migrated (Davis, 1951). Big communities of old Indian diaspora, which settled mainly as a result of indentured labour, are in South Africa, Mauritius, Trinidad and Tobago, Guyana, Fiji, Reunion Islands and Surinam. As a consequence of the 'kangani' system, which was introduced even to places where there was previously no slave labour, there are large Indian communities also in Myanmar, Malaysia and Singapore ${ }^{54}$ (Singhvi, 2001, pp. xlvii-xlix).

After the Second World War, Indian communities dispersed all over the world. India gained its independence in 1947 and with it started a complete reorientation from South-South migration towards South-North migration. The Indian Diaspora that developed from these flows onward is referred to as the "new diaspora" as it is no longer linked directly to colonialism and early capitalism relationships. The "new diaspora" consists of groups of migrants, who are moving mainly to North America, Europe, and Australia in pursuit of highly skilled work and low-skilled workers moving to the Gulf, West and South East Asia. Nowadays, migration consisting mainly of Indian IT software specialists, engineers and health care workers continues to flow to the industrialized countries, while migration to the Middle East is dominated by low skilled labour, in particular construction work, transport orientations, and domestic services (Chanda \& Sreenivasan, 2006).

\footnotetext{
${ }^{53}$ Kangani system refers to a method of recruitment, where a mediator between the workers and managers of plantations was sent back to India to recruit new men and women, usually from his own region and caste (Rangaswamy 2000, 288).

54 There are an estimated 2,902,000 people of Indian origin in Myanmar, 1,665,000 in Malaysia, 1,000,000 in South Africa, 715,756 in Mauritius, 500,600 in Trinidad and Tobago, 395,350 in Guyana, 307,000 in Singapore, 336,829 in Fiji, 220,055 in Reunion Islands and 150,456 in Surinam (Singhvi et al. 2001, xlvii-xlix).
} 


\subsubsection{Student mobility from India}

Skilled Indians increasingly emigrate as students through the academic stream. The growth of international student mobility from India in recent years is remarkable. In the last decade alone, student mobility from India increased by more than three times. Internationalization of higher education has been a major driving force behind this trend, as well as a rising middle class in India which is increasingly able to afford foreign university programmes (Kumar et al., 2009). In addition, foreign student policies have become a tool in the international competition for skilled persons. This takes place through the so-called "two-steps migration"; namely, first through the attraction of international students, and then by their retention as skilled workers for the national labour markets (OECD, 2010a). In fact, many students decide to gain working experience abroad upon completion of their studies.

At the country level, India does not have systematic data on emigration of students or emigration of migrants in general. Concerning the emigration and student mobility, there are only some institution-based sample surveys from specific institutions like IITs. It is thus more reliable to use the data from destination countries. The figures on Indian student mobility in this section are therefore based on the data from host countries collected by OECD and UNESCO Institute for Statistics.

The data clearly show that Indian students have become a relevant country group in international migration flows. Figure 6.1 demonstrates numbers of international students from ten major countries of origin for all reporting countries to $O E C D^{55}$. Students from these ten countries represent 37.4 percent of all international students. After China, India is the second major country of origin for students who study abroad. In 2008, there were 184,501 Indian students in all reporting destination countries, of which 173,114 were reported for OECD countries (OECD, 2010d). UNESCO statistics demonstrate slightly different figures: in 2008, 170,256 Indian students are reported to be studying abroad. However, because of the high number of domestic students, they only represent 1.0 percent of the total tertiary enrolment in India. China, for comparison, had 441,186 students studying abroad in 2008 with an outbound mobility ratio of 1.7 percent (UNESCO-IUS, 2010b). Even though the overall mobility ratio for Indian students is low at only 1 percent, they signify a noticeable portion of student body in certain countries (15.2 percent in

\footnotetext{
55 Education at a Glance 2010: OECD Indicators features data on education from the 31 OECD member countries and five countries that participated in the OECD Indicators of Education Systems Programme (INES), namely Brazil, Estonia, Israel, the Russian Federation and Slovenia (they were not yet OECD member states at the time), and three non-OECD member countries that participate in the OECD's Enhanced Engagement process, namely China, India and Indonesia.
} 
the United States, 13 percent in New Zealand, 11.5 percent in Australia and 7.7 percent in United Kingdom) (OECD, 2010b).

Figure 6.1: Major countries of origin for internationally mobile students for all reporting destinations, 2008
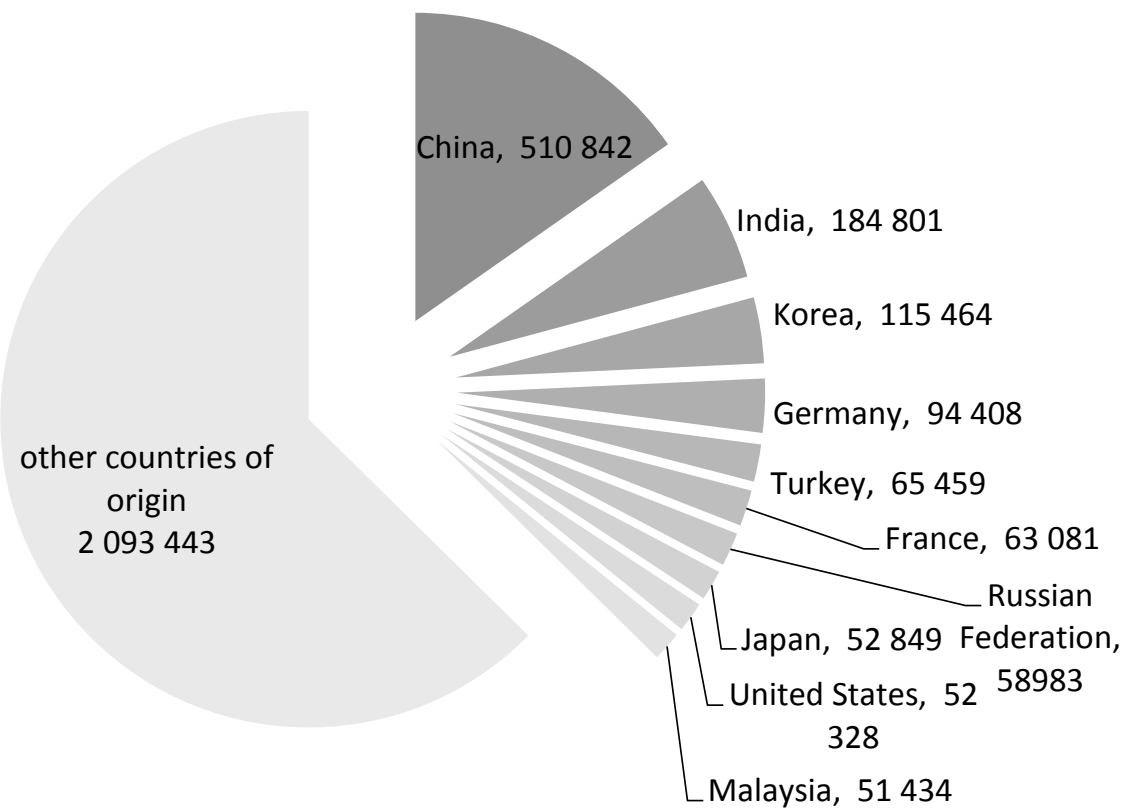

Source: (OECD, 2010d), Author's analysis

\subsection{Descriptive analysis: Planned move abroad versus stay in India}

\subsubsection{Characteristic differences of movers and non-movers}

In line with expectations, a large share of survey respondents stated that they consider moving abroad in the future, with 63.6 percent of the studied students. These results are in line with findings from the survey among Indian IT students, conducted by Mahmood and Schömann (2003b), which found that 68 percent of their student sample replied that they do wish to migrate upon completion of their studies.

Since this study addresses a student population, it is in line with expectations that the majority of respondents indicate education as the main reason for moving 
$a^{a b r o a d}{ }^{56}$. As previously mentioned, this study includes any plans for international mobility, either for the purpose of education, for work or for another reason. Reasons for going abroad are strongly interconnected and oftentimes it is difficult for respondents to single out only one single reason. People often change from one migrant category to another or are at one given time in-between such categories. Working while studying, shifting to employment upon graduation, looking for employment abroad in order to accompany a partner are just some examples of how different reasons for mobility take place at the same time. Furthermore, it is very uncommon to go abroad for work directly from a university. As it was explained by several interviewees, most common options for students are to either first go abroad for postgraduate studies and stay longer for some work experience or find a placement with a multinational company in India, which then often sends people for assignments abroad. Therefore, the remainder of the chapter addresses exclusively the general question of having mobility plans or not.

To understand the factors which influence migration decision-making, we analyse if those students that wish to go abroad differ in characteristics substantially from those that wish to stay in India. The Pearson's Chi-square test is used to observe whether people with different characteristics also differ in frequency with which they report plans on moving abroad in the future. ${ }^{57}$ Table 6.1 illustrates the differences between the two groups. We observe that there are proportionally less female students among the ones that plan to move abroad. Within a group which reported plans on moving abroad, there are 26.9 percent female students, while among students without plans to move 32.3 percent are female.

\footnotetext{
${ }^{56}$ Among students who have plans to move abroad, $68.1 \%$ indicated further studies as the main reason for moving abroad, $25.5 \%$ choose work-related reasons and $6.4 \%$ other reasons.

57 The test of independence measures whether paired observations on two variables are independent of each other. Since our sample is small, we also use the Fisher's exact test for some of the variables. We further assess with a two-tailed test whether any of the categories of the selected values have an effect in terms of having plans for moving abroad or not. These tests are not aiming to make causal claims for determining the decision to move abroad; they only show correlations between intentions to move abroad and the selected variables, which provide us with additional information on determinants, opening the field for further causal empirical evaluations.
} 
Table 6.1: Comparison of the S\&E students by main characteristics (in \%)

\begin{tabular}{|c|c|c|c|}
\hline Total N=412 & $\begin{array}{l}\text { No plan to move } \\
\text { abroad } \\
36.41\end{array}$ & $\begin{array}{l}\text { Plan to move } \\
\text { abroad } \\
63.59\end{array}$ & $\begin{array}{l}\text { Total } \\
100\end{array}$ \\
\hline \multicolumn{4}{|l|}{ Personal characteristics } \\
\hline $\begin{array}{l}\text { Gender }(\operatorname{Pr}=0.292) \\
\text { female } \\
\text { male } \\
\mathrm{N}=327\end{array}$ & $\begin{array}{l}32.31 \\
67.69\end{array}$ & $\begin{array}{l}26.90 \\
73.10\end{array}$ & $\begin{array}{l}29.05 \\
70.95\end{array}$ \\
\hline $\begin{array}{l}\text { Age } * * *(\operatorname{Pr}=0.000) \\
\text { younger than } 22 \text { years } * * * \\
\text { from } 23 \text { to } 26 \text { years } \\
27 \text { and older*** } \\
\mathrm{N}=318\end{array}$ & $\begin{array}{l}56.92 \\
32.31 \\
10.77\end{array}$ & $\begin{array}{l}27.66 \\
37.23 \\
35.11\end{array}$ & $\begin{array}{l}39.62 \\
35.22 \\
25.16\end{array}$ \\
\hline $\begin{array}{l}\text { Community** }(\operatorname{Pr}=0.012) \\
\text { Non-Hindu } \\
\text { Hindu } \\
\mathrm{N}=302\end{array}$ & $\begin{array}{l}13.39 \\
86.61\end{array}$ & $\begin{array}{l}25.14 \\
74.86\end{array}$ & $\begin{array}{l}20.20 \\
79.80\end{array}$ \\
\hline $\begin{array}{l}\text { Reserved group }(\operatorname{Pr}=0.202) \\
\text { reserved group } \\
\text { non-reserved group } \\
N=310\end{array}$ & $\begin{array}{l}13.11 \\
86.89\end{array}$ & $\begin{array}{l}18.62 \\
81.38\end{array}$ & $\begin{array}{l}16.45 \\
83.55\end{array}$ \\
\hline $\begin{array}{l}\text { Relationship }(\operatorname{Pr}=0.125) \\
1=\text { single } \\
2=\text { relationship (boyfriend/girlfriend) } \\
3=\text { married* } \\
N=320\end{array}$ & $\begin{array}{l}78.46 \\
15.38 \\
6.15\end{array}$ & $\begin{array}{l}75.79 \\
11.58 \\
12.63\end{array}$ & $\begin{array}{l}76.88 \\
13.13 \\
10.00\end{array}$ \\
\hline $\begin{array}{l}\text { Children }(\operatorname{Pr}=0.393) \\
0=\text { no children } \\
1=\text { children } \\
N=321\end{array}$ & $\begin{array}{l}77.86 \\
22.14\end{array}$ & $\begin{array}{l}73.68 \\
26.32\end{array}$ & $\begin{array}{l}75.39 \\
24.61\end{array}$ \\
\hline \multicolumn{4}{|l|}{ University characteristics } \\
\hline $\begin{array}{l}\text { University*** }(\operatorname{Pr}=0.000) \\
1=J N U^{* * *} \\
\text { 2=IISc Bangalore } \\
\text { 3=IIT Delhi } \\
4=\text { BHU-IT*** } \\
5=J a m m u \\
N=350\end{array}$ & $\begin{array}{l}27.41 \\
19.26 \\
22.96 \\
15.56 \\
14.81\end{array}$ & $\begin{array}{l}50.23 \\
22.33 \\
6.51 \\
9.77 \\
11.16\end{array}$ & $\begin{array}{l}41.43 \\
21.14 \\
12.86 \\
12.00 \\
12.57\end{array}$ \\
\hline $\begin{array}{l}\text { Field of studies }(\operatorname{Pr}=0.123) \\
1=\text { natural sciences } \\
2=\text { engineering } \\
N=314\end{array}$ & $\begin{array}{l}29.41 \\
70.59\end{array}$ & $\begin{array}{l}37.95 \\
62.05\end{array}$ & $\begin{array}{l}34.71 \\
65.29\end{array}$ \\
\hline $\begin{array}{l}\text { Level of studies } * * *(\operatorname{Pr}=0.000) \\
1=\text { Bachelor programmes*** } \\
2=\text { Masters programmes* }\end{array}$ & $\begin{array}{l}37.82 \\
41.18\end{array}$ & $\begin{array}{l}19.89 \\
31.18\end{array}$ & $\begin{array}{l}26.89 \\
35.08\end{array}$ \\
\hline
\end{tabular}




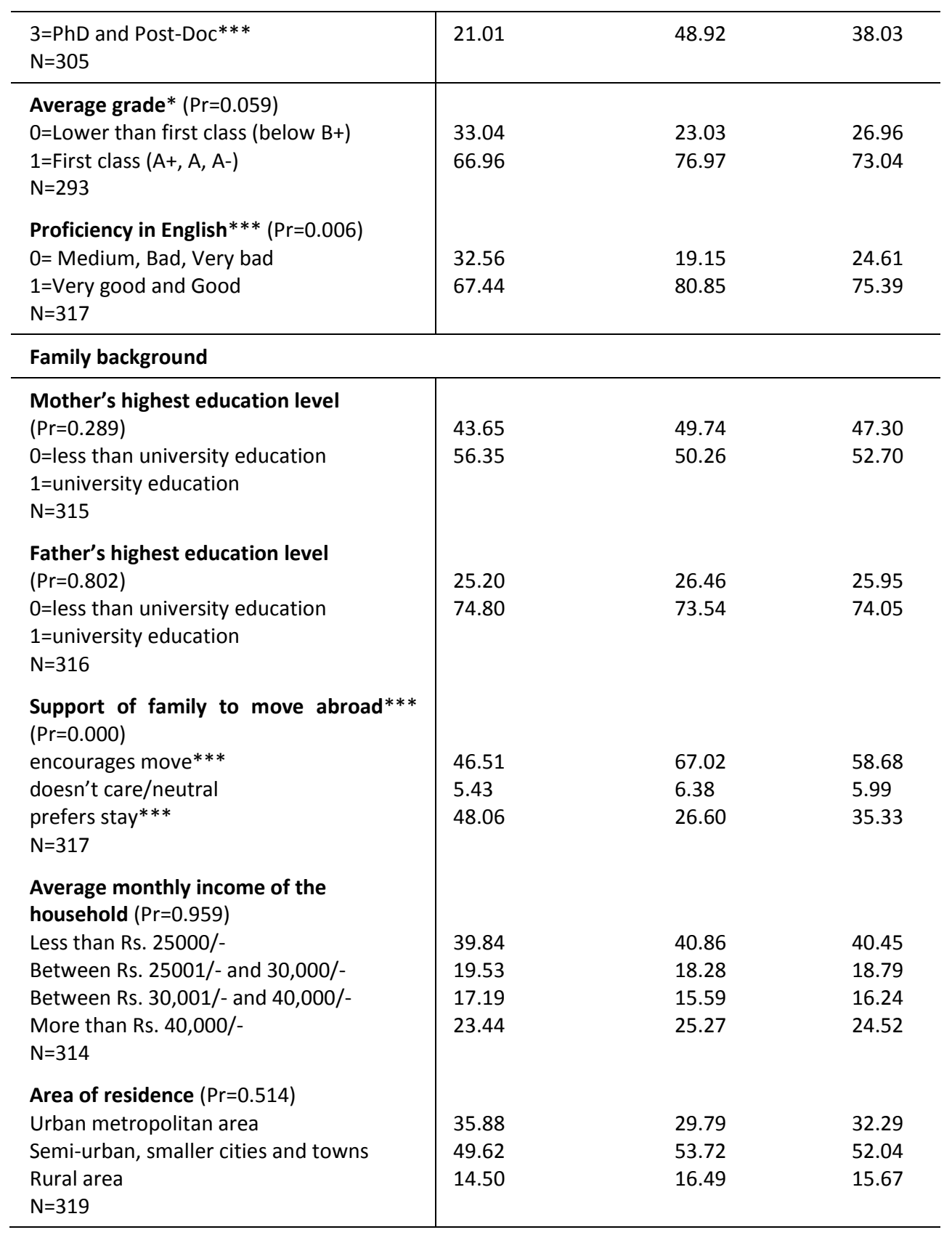




\begin{tabular}{|c|c|c|c|}
\hline \multicolumn{4}{|l|}{ Migration history } \\
\hline $\begin{array}{l}\text { not lived abroad }(\mathrm{Pr}=0.195) \\
\text { lived abroad } \\
\mathrm{N}=371\end{array}$ & $\begin{array}{l}89.12 \\
10.88\end{array}$ & $\begin{array}{l}84.38 \\
15.63\end{array}$ & $\begin{array}{l}86.25 \\
13.75\end{array}$ \\
\hline \multicolumn{4}{|l|}{ Network abroad } \\
\hline $\begin{array}{l}\text { Parents }(\operatorname{Pr}=0.478) \\
\text { not lived abroad } \\
\text { lived abroad } \\
\mathrm{N}=289\end{array}$ & $\begin{array}{l}93.10 \\
6.90\end{array}$ & $\begin{array}{l}90.75 \\
9.25\end{array}$ & $\begin{array}{l}91.70 \\
8.30\end{array}$ \\
\hline $\begin{array}{l}\text { Siblings ( } \mathrm{Pr}=0.494) \\
\text { not lived abroad } \\
\text { lived abroad } \\
\mathrm{N}=289\end{array}$ & $\begin{array}{l}80.51 \\
19.49\end{array}$ & $\begin{array}{l}83.63 \\
16.37\end{array}$ & $\begin{array}{l}82.35 \\
17.65\end{array}$ \\
\hline $\begin{array}{l}\text { Extended family }(\operatorname{Pr}=0.847) \\
\text { not lived abroad } \\
\text { lived abroad } \\
\mathrm{N}=293\end{array}$ & $\begin{array}{l}56.67 \\
43.33\end{array}$ & $\begin{array}{l}57.80 \\
42.20\end{array}$ & $\begin{array}{l}57.34 \\
42.66\end{array}$ \\
\hline $\begin{array}{l}\text { Friends** }(\mathrm{Pr}=0.012) \\
\text { not lived abroad } \\
\text { lived abroad } \\
\mathrm{N}=289\end{array}$ & $\begin{array}{l}57.89 \\
42.11\end{array}$ & $\begin{array}{l}42.86 \\
57.14\end{array}$ & $\begin{array}{l}48.79 \\
51.21\end{array}$ \\
\hline $\begin{array}{l}\text { Colleagues*** }(\mathrm{Pr}=0.000) \\
\text { not lived abroad } \\
\text { lived abroad } \\
\mathrm{N}=285\end{array}$ & $\begin{array}{l}73.68 \\
26.32\end{array}$ & $\begin{array}{l}49.71 \\
50.29\end{array}$ & $\begin{array}{l}59.30 \\
40.70\end{array}$ \\
\hline
\end{tabular}

Note: Pearson's Chi-square test and Fisher's exact test

Significance levels $* p<0.1, * * p<0.05, * * * p<0.01$

Critical values for the two-tailed test: 1.645 for confidence level 90\%*, 1.96 for confidence level 95\%**, 2.575 for confidence level 99\%***

Age clearly also plays a role in plans related to migration, with students who plan to move abroad being on average older. ${ }^{58}$ Among the students who report migration plans, around 35 percent are 27 years or older, while only 10.8 percent of "non-movers" 59 belong to this age group. With respect to students' community belonging, we notice that students from minority communities are highly represented among students with plans to move abroad. ${ }^{60}$ Among students with migration intentions, students from non-Hindu communities represent 25.1 percent, while in the group with no migration aspirations, they represent only 13.4

\footnotetext{
${ }^{58}$ The results from the Chi-square test indicate a statistically significant relationship between plans on moving abroad and age groups at $99 \%$ confidence level.

${ }^{59}$ For the purpose of simplicity, we henceforth refer to students who report plans on moving abroad also as "movers" and to those that do not have plans on moving abroad also as "non-movers".

60 The relationship between community belonging and plans to move abroad is statistically significant at $95 \%$ confidence level.
} 
percent. Similarly, the proportion of students belonging to a reserved group under the quota system is bigger among "movers" in comparison with their proportion among "non-movers" (18.6 percent and 13.1 percent, respectively). In relation to students' relationship status, we observe a statistically significant correlation with mobility plans. Students who are married indicate a higher intention to move abroad.

With respect to the university background of the students, we observe a number of differences in their reported plans on mobility. The differences between universities are statistically significant. ${ }^{61}$ Students from JNU are more likely to express plans to move abroad, while BHU-IT stands out with predominantly homeoriented students. Compared to students of engineering fields, those in natural sciences have a higher representation among the students who plan to move (38 percent) as compared to the group of students without such plans (29.4 percent). Also, the level of studies influences the plans on mobility. ${ }^{62} \mathrm{PhD}$ students and postdoctoral students indicate more often they want to move abroad than Bachelor and Master students ${ }^{63}$. PhD students and post-doctoral students also represent the largest share of "movers" (49 percent) and a lot smaller share among the "nonmovers" (21 percent). Bachelor students, on the other hand, represent the smallest share (19.9 percent) among the "movers" and a considerably larger share among the students, who are not planning to move (37.8 percent). Also in terms of study achievements, we find a difference between "movers" and "non-movers". ${ }^{64}$ Students who have high grades consider moving abroad more often than students with lower grades. 77 percent of the sub-sample of students with moving intentions has first class grades, which is substantially higher than 67 percent of first class students among those with no moving intentions. Proficiency in English also divides the students in two dissimilar groups. ${ }^{65}$ Students with mobility plans have a better command of English and in 80.8 percent of cases report that their English is either good or very good. Only 67.4 percent of students who do not plan moving abroad think of their knowledge of English language as good or very good.

Regarding the family background, we do not find any significant differences between the two groups of interest regarding their parents' educational background. Similarly, household incomes are similar between the two groups.

\footnotetext{
${ }^{61}$ Relationship between the chosen universities and plans on moving abroad is statistically significant at $99 \%$ confidence level.

${ }^{62}$ Relationship is statistically significant at a 99\% confidence level.

${ }^{63}$ For Bachelors and PhD students, these results are significant at $99 \%$ confidence level. Master students are more likely to among the "non-movers" at 95\% confidence level.

${ }^{64}$ The difference is statistically significant at $90 \%$ confidence level.

65 The difference is statistically significant at $99 \%$ confidence level.
} 
There are differences, however, in the family support to move abroad. ${ }^{66}$ While students with moving intentions report in 67 percent of cases that their family encourages their move abroad, this share drops to only 46.5 percent for students who do not consider moving abroad. With respect to families' area of residence, we observe a minor difference in the proportion of students from urban metropolitan areas. Students who plan to move abroad have a lower representation of students from urban areas as compared to the proportion this equivalent group of students has among the non-movers.

The results of the survey comply with the expectation that students with prior migration experiences more often have plans to move again in the future. Looking at the network that students might have in their family and friends with prior migration experiences, we expect that students with plans to move abroad more often have access to such networks. This proves to be the case for friends and colleagues, but less with respect to close and extended family networks. It is interesting to note that among students who do not have plans to move abroad, larger proportions have siblings or extended family members who live or have lived abroad, in comparison to students who have plans to move. However, when observing students' network of friends and colleagues, 57.1 percent of students with mobility plans have friends who live or have lived abroad and only 42.1 percent of students without mobility plans have such friends. With respect to colleagues, this difference becomes even more apparent; 50.3 percent of the "movers" have colleagues abroad compared to 26.3 percent for "non-movers" ${ }^{67}$

\subsubsection{Evaluation of the factors influencing migration intentions}

In this section, we examine how students' preference influences plans of Indian students on future mobility. The students were asked to rank a list of 26 factors on a five-point Likert scale, indicating for each factor the importance this factor has in selecting the place where they would like to live ${ }^{68}$. These factors are not all seen as exogenous to migration planning but we view them as a helpful descriptive instrument for better understanding migration decisions (Gibson \& McKenzie, 2009). We are interested to see whether preferences for the named factors differ among people who plan to move abroad and the ones that do not have such plans. The differences in preferences can help us explain which factors draw students abroad and which factors make them want to stay in their home country. Figure

\footnotetext{
${ }^{66}$ The difference is statistically significant at $99 \%$ confidence level.

67 The differences in reporting plans for future mobility are statistically significant for the variable on friends (at

$5 \%$ ) and colleagues (at 1\%). The differences are not statistically significant for the variable on parents, siblings or extended family.

${ }^{68}$ The students were asked to rank the importance of specific factors on a scale from 1 to 5 , with $1=$ not important at all, 2 = somewhat unimportant, 3 = neutral, 4 = somewhat important 5 = very important.
} 
6.2 presents mean responses for each factor separately for people that plan moving abroad in the near future and for those who did not report such plans in the survey. If people in these two groups view factors differently, it might help us explain why some of them want to migrate and the others do not.

Figure 6.2: How important do you consider the presence of the following characteristics/facilities in a country where you want to live?

1. high demand for my qualifications

2. easily finding a suitable job after my studies

3. attractive salary

4. quality and content of your work

5. good research facilities in companies and..

6. no more than 8-hour working days

7. career progression opportunities

8. recognition of educational/professional..

9. job security (not easy for employers to fire...

10. costs of living

11. family-friendly environment

12. good quality of higher education institutions

13. multicultural environment

14. rich cultural institutions (museum, cinema, ...)

15. public safety

16. political stability, stable government

17. economic stability

18. social equality among population

19. friendly, hospitable population

20. not feeling discriminated

21. English commonly spoken

22. no need to learn a new language

23. having high social status

24. attractive taxation system

25. quality and access to medical services..

26. social security and benefits (such as.
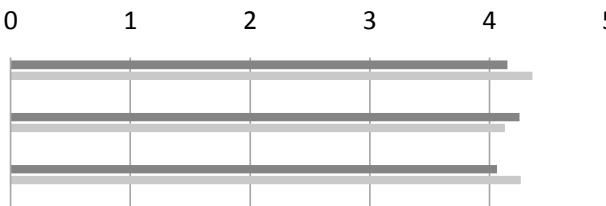

5
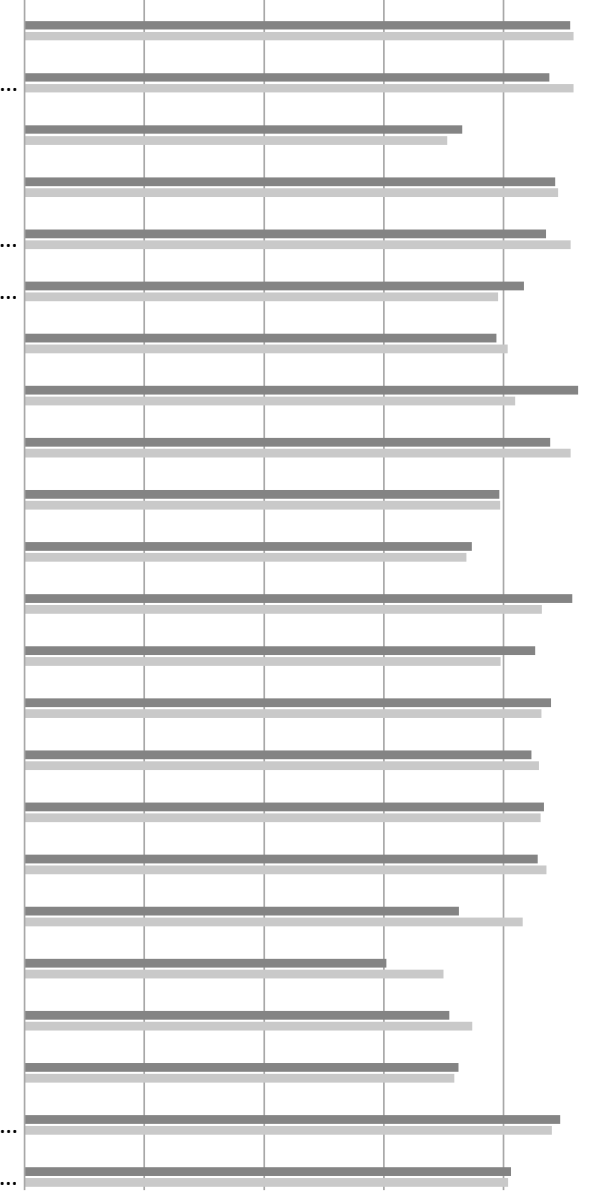

no intend to move intend to move

Note: Answers on a scale from 1-5 (1 = not important at all, 2= somewhat unimportant, 3= don't know/ neutral, 4=somewhat important, 5 = very important), in mean values 
Our hypothesis was that people who value work-related factors higher will more often express plans to move abroad and people who value local environment, social contacts and public services will prefer staying in India. This hypothesis is, however, only partially proven. Observing the individual factor evaluation, we notice a general agreement across both groups of students. We can observe that all students rank work-related factors as the most important, regardless of their plans to move abroad. Quality and content of work and career progression opportunities are on average considered among the most important for both groups of students. There is also an agreement on the least important factors for the choice of the place where they want to live in the future. The need to learn a new language does not appear to play an important role for either of the two groups of students. Although students, who want to move abroad, give this factor a much higher average score, they still assess it as on average the least important in comparison to the other factors. An 8-hour working schedule, having high social status and an attractive taxation system are among the other factors which also rank low in importance for both groups.

What is most relevant for this study are those factors which are viewed differently by "movers" and "non-movers". Factors which are assessed higher by students with migration plans concern the use of spoken languages in the place where they want to live. Understandably, they consider it much more important that English is commonly spoken in the host country. Likewise, it is more relevant for students with moving intentions that they would not have to learn a new language. These students also assess the demand for their qualifications, recognition of qualifications, good research facilities and high salaries higher compared to students without mobility intentions. This is in line with our hypothesis that career advancement opportunities draw people abroad. At the same time, family-friendly environment, political stability, public safety and job security are on average evaluated higher by people who did not express plans to move abroad. The difference in the importance of the named factors can be explained by risk preferences of respondents. These results are in line with earlier studies which have shown that more risk-averse people are less likely to have ever migrated (e.g. Gibson \& McKenzie, 2009; Jaeger et al., 2008).

We have so far demonstrated that there are characteristic differences between people with plans to move and those with plans to stay, as well as at point significantly different evaluations of factors influencing migration intentions. To identify which of these factors really increase the likelihood that students express plans to move, we use a logistic regression analysis in the next section. 


\subsection{Empirical analysis of migration intentions}

\subsubsection{Logistic Regression Model Specifications}

The purpose of this chapter is to observe which individual and structural characteristics and perceptions determine whether individuals have plans to move abroad in the near future or not. As described earlier, the dependent variable is the existing disposition of a student to move to another country. This variable is based on the answer to the first question in the survey: "Are you considering moving abroad?" There were two possible answers to this question: yes and no, which allows us to use the binary logit model.

The dependent variable "plan to move abroad" is a binary variable where

$\mathrm{Y}_{\mathrm{i}}= \begin{cases}1 ; & \text { if the student intends to move abroad } \\ 0 ; & \text { if the student does not plan to move abroad }\end{cases}$

with $p\left(x_{i}\right)=p\left(y_{i}=1 \mid X=x_{i}\right)$ as the conditional probability of $y_{i}=1$ given the covariate $X=x_{i}$.

The independent variables are a vector of individuals' characteristics and perceptions, which are used to predict which individuals are more likely to intend moving abroad. Logistic regression allows the estimation of a discrete outcome from a set of independent variables, that can be categorical, continuous, dichotomous, or a mixture of these types. The results of the logit probability model show which variables increase or decrease the likelihood of having plans to move abroad and whether these influences are significant. Table 6.2 presents the marginal effects from logit estimation of the correlates of planning the move abroad. ${ }^{69}$ Because of item non-response, not all variables are available for every respondent. Therefore, we first investigate the role of various sets of variables, before combining all of them together. Since the estimations in different models have different numbers of observations, it is difficult to interpret R2. To have a measure which is comparable across models, we use a measure of goodness of fit (GOF) which shows the percentage of correctly estimated cells. GOF describes how each model fits the set of observation.

We test for a subset of models, in which we explore the role of different sets of variables to test the hypothesis presented in Chapter 5. In the last model, we combine all variables. In all models, we include gender, community belonging and reserved status as control variables.

\footnotetext{
${ }^{69}$ The table 6.3 in the Appendix shows the coefficients and standard errors of the logistical regression.
} 
Table 6.2: What determines plans to move abroad? (Marginal effects after logit regression)

\begin{tabular}{|c|c|c|c|c|c|c|}
\hline & Model 1 & Model 2 & Model 3 & Model 4 & Model 5 & Model 6 \\
\hline \multicolumn{7}{|c|}{ Dependent variable: Plan to move abroad } \\
\hline $\begin{array}{l}\text { Female } \\
\text { (reference: from a }\end{array}$ & $\begin{array}{l}-0.053 \\
(0.099)\end{array}$ & $\begin{array}{l}-0.207 * * * \\
(0.058)\end{array}$ & $\begin{array}{l}-0.078 \\
(0.091)\end{array}$ & $\begin{array}{l}-0.064 \\
(0.082)\end{array}$ & $\begin{array}{c}-0.062 \\
(0.090)\end{array}$ & $\begin{array}{l}-0.113^{*} \\
(0.063)\end{array}$ \\
\hline $\begin{array}{l}\text { Hindu community) } \\
\text { from a non-Hindu } \\
\text { community }\end{array}$ & $\begin{array}{l}0.132 \\
(0.128)\end{array}$ & $\begin{array}{l}0.142 \\
(0.144)\end{array}$ & $\begin{array}{l}0.128 \\
(0.125)\end{array}$ & $\begin{array}{l}0.159 \\
(0.113)\end{array}$ & $\begin{array}{l}0.075 \\
(0.133)\end{array}$ & $\begin{array}{l}0.121 \\
(0.168)\end{array}$ \\
\hline $\begin{array}{l}\text { (reference: from a } \\
\text { non-reserved } \\
\text { group) } \\
\text { from a reserved } \\
\text { group }\end{array}$ & $\begin{array}{l}0.092^{*} \\
(0.055)\end{array}$ & $\begin{array}{l}0.081 \\
(0.062)\end{array}$ & $\begin{array}{l}0.050 \\
(0.072)\end{array}$ & $\begin{array}{l}0.045 \\
(0.074)\end{array}$ & $\begin{array}{l}0.079 \\
(0.054)\end{array}$ & $\begin{array}{l}-0.044 \\
(0.130)\end{array}$ \\
\hline $\begin{array}{l}\text { (reference: single } \\
\text { as a reference) } \\
\text { in a } \\
\text { relationship/marri } \\
\text { ed }\end{array}$ & $\begin{array}{l}0.056 \\
(0.069)\end{array}$ & & & & & $\begin{array}{l}0.031 \\
(0.130)\end{array}$ \\
\hline has children & $\begin{array}{l}0.059 \\
(0.140)\end{array}$ & & & & & $\begin{array}{l}0.021 \\
(0.055)\end{array}$ \\
\hline $\begin{array}{l}\text { (reference: } \\
\text { research-oriented } \\
\text { universities) } \\
\text { Practical/applied } \\
\text { universities }\end{array}$ & & $\begin{array}{l}-0.268 * * * \\
(0.028)\end{array}$ & & & & $\begin{array}{l}-0.301 * * \\
(0.146)\end{array}$ \\
\hline $\begin{array}{l}\text { (reference: studies } \\
\text { engineering) } \\
\text { studies natural } \\
\text { sciences }\end{array}$ & & $\begin{array}{l}0.005 \\
(0.084)\end{array}$ & & & & $\begin{array}{l}0.003 \\
(0.121)\end{array}$ \\
\hline $\begin{array}{l}\text { (reference: } \\
\text { enrolled in } \\
\text { Bachelors } \\
\text { programme) } \\
\text { enrolled in Masters } \\
\text { programme }\end{array}$ & & $\begin{array}{l}-0.037 \\
(0.105)\end{array}$ & & & & $\begin{array}{l}-0.046 \\
(0.154)\end{array}$ \\
\hline $\begin{array}{l}\text { doing a PhD or } \\
\text { Post-Doc }\end{array}$ & & $\begin{array}{l}0.166 * * \\
(0.076)\end{array}$ & & & & $\begin{array}{l}0.030 \\
(0.149)\end{array}$ \\
\hline $\begin{array}{l}\text { (reference: mother } \\
\text { with less than } \\
\text { university } \\
\text { education) } \\
\text { mother with } \\
\text { university } \\
\text { education }\end{array}$ & & & $\begin{array}{l}-0.031 \\
(0.079)\end{array}$ & & & $\begin{array}{l}-0.193 \\
(0.170)\end{array}$ \\
\hline $\begin{array}{l}\text { (reference: father } \\
\text { with less than } \\
\text { university } \\
\text { education) }\end{array}$ & & & $\begin{array}{l}0.064 \\
(0.108)\end{array}$ & & & $\begin{array}{l}0.001 \\
(0.089)\end{array}$ \\
\hline
\end{tabular}




\begin{tabular}{|c|c|c|c|c|}
\hline $\begin{array}{l}\text { father with } \\
\text { university } \\
\text { education }\end{array}$ & & & & \\
\hline $\begin{array}{l}\text { (reference: parents } \\
\text { prefer stay) } \\
\text { parents encourage } \\
\text { move } \\
\text { parents neutral to } \\
\text { move }\end{array}$ & $\begin{array}{l}0.255^{* * *} \\
(0.034) \\
0.155 \\
(0.149)\end{array}$ & & & $\begin{array}{l}0.237 * * * \\
(0.054) \\
0.238 * * * \\
(0.067)\end{array}$ \\
\hline $\begin{array}{l}\text { (reference: below } \\
\text { average household } \\
\text { income) } \\
\text { above average } \\
\text { household income }\end{array}$ & $\begin{array}{l}0.016 \\
(0.108)\end{array}$ & & & $\begin{array}{l}0.046 \\
(0.157)\end{array}$ \\
\hline $\begin{array}{l}\text { (reference: from } \\
\text { an urban area) } \\
\text { from a semi-urban } \\
\text { area } \\
\text { from a rural area }\end{array}$ & $\begin{array}{l}0.103^{*} \\
(0.059) \\
0.085 \\
(0.076) \\
\end{array}$ & & & $\begin{array}{l}0.193 * * \\
(0.098) \\
0.068 \\
(0.143) \\
\end{array}$ \\
\hline $\begin{array}{l}\text { (reference: } \\
\text { respondent never } \\
\text { lived outside India) } \\
\text { lived outside India } \\
\text { in the past }\end{array}$ & & $\begin{array}{l}0.160 \\
(0.119)\end{array}$ & & $\begin{array}{l}0.034 \\
(0.097)\end{array}$ \\
\hline $\begin{array}{l}\text { parents have lived } \\
\text { abroad } \\
\text { siblings have lived } \\
\text { abroad } \\
\text { extended family } \\
\text { lived abroad } \\
\text { friends lived } \\
\text { abroad } \\
\text { colleagues lived } \\
\text { abroad }\end{array}$ & & $\begin{array}{l}0.001 \\
(0.109) \\
0.002 \\
(0.071) \\
-0.096 \\
(0.115) \\
0.082 \\
(0.076) \\
0.240 * * * \\
(0.063) \\
\end{array}$ & & $\begin{array}{l}0.157^{* *} \\
(0.074) \\
-0.085 \\
(0.146) \\
0.025 \\
(0.192) \\
0.125 \\
(0.194) \\
0.176^{* *} \\
(0.078) \\
\end{array}$ \\
\hline $\begin{array}{l}\text { importance of } \\
\text { quality and } \\
\text { content of work } \\
\text { importance of } \\
\text { attractive salary }\end{array}$ & & & $\begin{array}{l}0.053 \\
(0.057) \\
\\
0.043 \\
(0.046)\end{array}$ & $\begin{array}{l}0.013 \\
(0.063) \\
0.101 * * \\
(0.048)\end{array}$ \\
\hline $\begin{array}{l}\text { importance of } \\
\text { good quality of } \\
\text { education } \\
\text { institutions } \\
\text { importance of } \\
\text { family-friendly } \\
\text { environment } \\
\text { importance of } \\
\text { public safety }\end{array}$ & & & $\begin{array}{l}0.148 \\
* * * \\
(0.042) \\
- \\
0.236 * * * \\
(0.048) \\
- \\
0.105 * * * \\
(0.017)\end{array}$ & $\begin{array}{l}0.155^{*} \\
(0.080) \\
\\
-0.281^{* *} \\
(0.108) \\
-0.124 \\
(0.108)\end{array}$ \\
\hline
\end{tabular}




\begin{tabular}{|c|c|c|c|c|c|c|}
\hline $\begin{array}{l}\text { importance of } \\
\text { English commonly } \\
\text { spoken } \\
\text { importance of } \\
\text { medical services }\end{array}$ & & & & & $\begin{array}{l}0.146 * * * \\
(0.035) \\
-0.035 \\
(0.037) \\
\end{array}$ & $\begin{array}{l}0.099 * * * \\
(0.034) \\
-0.122 * * \\
(0.058) \\
\end{array}$ \\
\hline $\begin{array}{l}\text { Number of } \\
\text { observations }\end{array}$ & 287 & 264 & 273 & 236 & 266 & 194 \\
\hline Pseudo $\mathrm{R}^{2}$ & 0.0198 & 0.1016 & 0.0604 & 0.0877 & 0.1809 & 0.3250 \\
\hline GOF & $60.3 \%$ & $70.5 \%$ & $64.1 \%$ & $67.4 \%$ & $69.9 \%$ & $79.4 \%$ \\
\hline Pearson chi ${ }^{2}$ & $\begin{array}{l}14.7 \\
(0.84)\end{array}$ & $50.9(0.10)$ & $\begin{array}{l}141.8 \\
(0.03) \\
\end{array}$ & $\begin{array}{l}73.7 \\
(0.62) \\
\end{array}$ & $\begin{array}{l}193.7 \\
(0.70) \\
\end{array}$ & $\begin{array}{l}169.8 \\
(0.36) \\
\end{array}$ \\
\hline
\end{tabular}

Notes: All models are estimated by logistic regression. Dependent variable is the plan to move abroad. All standard errors (in parentheses) are robust and clustered by university groups.

Significance levels $* * * p<0.01, * * p<0.05,{ }^{*} p<0.1$

GOF is percentage of correctly classified data points. Pearson is a chi2 goodness of fit test. Number is parenthesis is the $p$-value of the Pearson test.

The first model looks only at the role of personal characteristics and shows significant effects only for belonging to a reserved group, i.e. plans to move abroad are more likely among students who belong to a reserved group. However, these significant effects disappear in the more comprehensive models. Another interesting finding, however with statistically insignificant results, is that students belonging to Hindu communities are less likely to have mobility plans. This is consistent with the hypothesis that people from minority groups attribute higher benefits to moving abroad since their options in the home country are worse in comparison with the majority group. We also find out that female respondents are less likely to express moving intentions, however, the results are not significant.

As shown in the descriptive statistics in Table 6.1 age visibly plays a role in plans related to migration, with students who plan to move abroad being on average older. When estimating logit regressions models with the same specifications as presented in Table 6.2 and including the variables for age, we see that age has statistically significant effects on plans to move abroad in all of the models. In line with the expectations, we find that older students are more likely to plan moving abroad. The odds for students who are 27 or older to express mobility plans are more than six times bigger in comparison to the reference group (students till the age of 22). Since the variable for age is strongly correlated with some other explanatory variables such as having children or the educational level of students, it takes a lot of explanatory power from the other variables. We hence decided to present the regression results for models without the age variable, while recognizing the relevance of respondents' life cycle for their decision about moving abroad or staying in India. 
Model 2 investigates the role of university background. This model and all other models also include variables on gender and community belonging, together with other variables of interest. We do not find significant differences between students in engineering and natural sciences. We divided the five observed universities in two groups along the line of practical universities and research oriented ones. JNU, University of Jammu and IISC Bangalore are grouped together as research-oriented institutions. IIT Delhi and BHU-IT are clustered in the second group of practical institutions. The results show that there is significant difference between these two groups, with students from research-oriented universities more likely reporting mobility intentions. Employment opportunities for students from practical universities, such as IITs, have improved greatly in India, which decreases the motivations for looking for opportunities abroad. The Associate Dean of Students at IIT Delhi, Prof. Shashi Mathur explains that due to lack of financial assistance for studying abroad and difficulties of finding jobs, most IIT students opt for joining multinational companies which come to on-campus placements. On the contrary, for students, who want to specialize in academic research, the expectation to pursue further studies or work abroad still persists. This finding is supported by significant differences in terms of mobility plans for students enrolled in different educational levels. In comparison with students who are enrolled in a Bachelor programme, respondent who are doing a $\mathrm{PhD}$ or hold a post-doctoral position are significantly more likely to have plans to move abroad, which demonstrates the international orientation of people pursuing academic careers.

Model 3 further examines whether plans on mobility vary according to family background of students. Education of parents and household income do not show significant effects on students' mobility plans. The hypothesis that families matter in the decision-making on moving abroad is, however, proven by the result that students who have support from their family are significantly more likely to plan a move abroad in the near future, significant at 1 percent. Also, students from semiurban areas of residence (compared to students from urban areas) are more likely to express mobility plans. Family background plays a strong role in students' future plans and a supporting family environment is necessary for peoples' ability to move abroad.

Model 4 further looks at the role of social networks. We observe whether students own migration history or migration experiences of family members, friends and colleagues effect their mobility plans for the future. As mentioned above, very few students have been out of India in the past or have any of their close family members with such experiences, these results have to be treated with caution. It turns out that only having colleagues who have been abroad in the past has a 
statistically significant effect on mobility plans, while friends abroad also have a small positive effect but insignificant. This is in line with Granovetter's (1973) hypothesis on the "strength of weak ties". Social ties consist of social relationship and of the resources they carry, which means that social networks facilitate migration only when they have access to the right resources.

Model 5 investigates the role of some of the preference variables that represent respondents' choices for working place and lifestyle. We focus on the aspects which are usually omitted from the studies but were assessed with high importance for the place where the studied respondents want to live. Good qualities of higher education institutions and English-speaking environment have a positive and significant effect on mobility intentions. On the contrary, students who assess family-friendly environment and public safety as very important are less likely to plan moving abroad. Importance of quality and content of work and access to medical services do not have a significant effect.

In the last model (6) we combine all these variables together. In the complete model, we see that mobility plans are more likely for male students who come from research universities, whose parents encourage their move abroad, come from semi-urban areas and whose parents and colleagues have lived abroad. In line with other studies and our expectations, the role of salary level is found to be significant. As in Model 5, such plans are more likely for those students who attribute high importance to quality of educational institutions and English-speaking environment. Same as above, importance for family-friendly environment is proven to keep students in the home country.

The reasons for changes in significance levels across the different models for some of the variables have been reviewed by different test. Due to item non-response not all variables are available for every respondent so the models are based on different numbers of observations, from $n=287$ in the most parsimonious specification to $n=194$ in the most complete model. To find out if changes in significance levels happen because of a different composition of observations in the models, we have undertaken several control checks. When testing the same models only on observations which include all of the variables in the models $(n=294)$, we find out that the results regarding the effect of belonging to a reserved group on mobility plans should be treated with caution. When testing the models on the smaller sample, the effect of belonging to a reserved group turns negative, just like in the last model, suggesting that changes in the coefficient signs for this variable, as presented in Table 6.2, are due to dropped observations in model 6. We do not find significant difference for the other variables. The explanatory power of model 6 is the strongest of all models, and we thus believe that the effects that were 
picked up by some variables in the earlier models are shifted to more influential variables in the last model.

\subsection{Discussion}

In this section, we will review the most interesting findings from paragraph 6.3, and reflect on them by taking advantage of qualitative study. Examining the determinants of international mobility plans for students at five selected universities in India, this study suggests that students' educational and family background matter most for their future intentions. The logistic regression showed that students from research-oriented universities, like JNU and IISc Bangalore, are more likely to report interest in taking up positions abroad. We thus reviewed what the interviewees indicated relating to the importance of work conditions in their decision, as well as the influence of social networks in the decision.

Work conditions: The main motivations were inductively derived from our interview data and reflect the prominence of work-related reasons for their mobility plans. Our in-depth interviews support the findings from the survey as better working conditions for research is the most often mentioned reason for Indian students who want to go abroad. As a male student of mechanical engineering at IIT Delhi put it, "since I'll be going there for work, either for work or for studies, the working environment should be good". Rashmi, a PhD student in life science at JNU, illustrated how for researchers in academia going abroad is a social norm associated with success:

We need to do it because this is preferred to have good post-docs, good publications in our field. Everybody does it. It's a normal thing, normal trend. Everybody. Our boss has also been for a Post-doc somewhere in USA. So it's a normal thing that everybody goes for.

Career progression: One of the key motivations for going abroad are perceived enhancements of career prospects and higher status implied in studying abroad. International positions give students "the edge over other people in India". People who are interested in an academic career have to follow the expectations of their specific fields. In the case of our target group, it appears that international exposure is highly valued. A male PhD student of environmental engineering at JNU describes this type of expectations in the context of India:

In the context of India, we say that, suppose if we go for future studies, if we see the future prospects in the field of education, it's somewhere a sort of feeling in the community, this whole education field, they think that a person who has gone abroad or so, who has seen all the things and who has got a 
good exposure out there; so it's sort of self-understanding in them that a person who went abroad, he must be having good knowledge, he must be having good exposure to the things and all that. So it's a sort of understanding. And in some institutes, it's a mandatory requirement that if you are applying for a faculty position that... Suppose we have IITs. So they have a mandatory requirement that your Post-Doc must be done in some other country or so. So it's a requirement in some fields. And to remain in this field, means in education line...

Similar reasoning was mentioned by several other respondents who want to pursue academic career in Indian universities. Better working conditions abroad are closely linked to reasons for going abroad in order to improve career prospects for the future. Scientific mobility, or as Meyer, Kaplan and Charum (2001) put it, "scientific nomadism" is considered as a normal part of an academic career and increasingly a necessity for career progression. The competition for academic posts is very strong, making at least part of their postgraduate education abroad necessary. The positions targeted by our respondents are at the few selected institutes in India which have many applicants for only a few opening positions. Only having a PhD is not sufficient for getting an academic post. "As I have seen my seniors without a Postdoc, even with a Postdoc it's difficult thing. A lot of people who actually have qualifications, they don't get it." As another PhD student in Environmental engineering from JNU explains his reasons for planning his post-doctoral studies either in the United States or Europe:

So in India, now not a lot of good research is going on. In very good universities in India, like JNU or NII (National Institute of Immunology) or the IISC Bangalore, they started good research. All the good research is going on in these universities in India. Average research is also going on so if I want to go in an average institute in India, I will get position but for a good university in India, it is tough for me to get a job there without any experience like a Postdoc. But in Europe even I if I get one Postdoc I can get a job there.

Better working/research conditions abroad: Better funding and infrastructure needed for research drive people to research institutes in which they can advance best during their stay abroad. "The primary reason for people going abroad from India is that they want to work in a good environment where people are dealing with new highly advanced technology," explains a male Master student of mechanical engineering at IISc Bangalore. Our respondents are currently based in good universities in India and for those who want to pursue their careers in academia, it is important to improve their technical skills in places with better infrastructure, where they get acquainted with different facilities and procedures. Sharmila, a PhD student in Environmental Sciences at JNU, wants to go abroad for 
postdoctoral research because of better facilities, the use of which would improve her future career prospects in academia.

Even in India to get into academic field position or becoming a professor, a postdoc is very necessary. And in India due to limited resources it would be nice if I could get an exposure to the advanced instrumentation so we can start things like that in India. ... of course with exposure to these instruments and facilities you will learn more and get more. It has an advantage if you do your Postdoc abroad compared to India.

Lack of facilities in India is related to the lack of financial support for research, which is especially relevant in certain fields. A PhD student of environmental engineering at JNU explains the problems with funding at Indian universities and why, according to him, this is the main reason for being able to do better research in Europe:

As far as Indian scenario, if I join as an assistant professor, then I will get the project here but the funding is less fast. Secondly, I cannot do average research if without funding. So if I am holding the same position in India as I will hold in Europe, I will do better research in Europe than in India. Because funding is the main problem. Also there is a lot of collaboration between all the European countries. So if you will get a project you will easily jump from one country to another for a research purpose. But for India you have to go for something like the visa and for funding.

Access to good facilities is more important in certain fields, especially when it comes to experimental research. A Master student in electronics and instrumentation from IISC Bangalore, explains why better research infrastructure is such an important drive for applying for PhD positions abroad.

If you have any plans for your theoretical works, I would prefer India. If you are going for some practical work, then the possibilities of funding here, when it reaches you, the time it takes ... it takes a lot of time. So in that sense, foreign or any developed country, mostly I will prefer that, because the funding will be free-going. Here, it is also free-going but it is very time consuming compared to the funding of the projects we would get there... Here the funding becomes difficult when it comes to engineering; if it comes to theoretical work, it is easy, just a scholarship will do. But if it comes to engineering or whatever research, you need a good funding. Maybe the industry or the industry sponsor there would get advantageous. Here, even in that sense you would not get it. In industries, there is reluctance towards research. So, obviously in other countries where they are investing they have good faith in research. They feel that it is good and that it is going to develop their own business. So, obviously they are interested in investing. 
The malfunctioning of the system in India was mentioned as a push factor by several other respondents. Because of bureaucratic hurdles and alleged corruption, "they are not able to do big things very fast and quick". A Master student of technical engineering at IISc Bangalore complains about the system in India:

So it's like I told if I go even for small things, like driver's license or to get a passport or things like that. Or dealing with government institutes like if I want to start my own company I have to get licenses or I have to get land and things like that. At every step I have to face corruption or biases like people out there in government organizations, they don't have a say fair approach, I mean maybe even in the US they might not be fair. But at least if you are working, you should be given a little smooth drive you know. It's not absolutely frictionless but at least it will be smoother than what currently exists in India. Yeah I mean I expect the overall quality of life to be better outside India, maybe it has to improve in India...

International exposure: Next to better working conditions, several students mentioned exposure to foreign cultures as an important drive for spending some time abroad. By going abroad, students get to "interact with students from different countries, teachers from different countries" and in this way "come to know about cultures of different countries". For example, Khartik, a Master student at the Center for Electronics Design and Technology explains:

You can get a global exposure other than staying only in India. You get to know people and their culture indeed. That is one of the aspects other than the studies, of course. You can learn how the people are there and see what other opportunities you might have. That is what l expect.

Financial benefits: Several respondents mentioned that the salary levels in India have improved a lot and that despite the fact that salaries would be higher abroad, this is not the turning point in the decision for international move. Especially for people in science and engineering, it is typical that they place less importance on monetary benefits of their work (De Grip et al., 2009). Nevertheless, higher remunerations abroad can make our respondents consider staying abroad for longer periods. Abijey, a Master student of aerospace engineering at IISc, who plans to stay abroad for some work experience after finishing his PhD says that his impression is that "if I work for two years, I will make as much money as here in India in maybe 10 years", which also means that his savings will be that much higher. Similarly, a Bachelor student in Mechanical engineering from IIT Delhi explains that after doing an MBA abroad "even if I don't want, I'll have to work (abroad) since going abroad to study is a very costly affair. So you can't pay back your loan or you can't support yourself without working there." 
Our hypothesis was that for students who want to move abroad careeradvancement opportunities are especially relevant. This is supported by results of the regression analysis as well as the information from in-depth interviews. Students who want to stay in India are found to have different preferences for the place where they want to live. Family-friendly environment and public safety in India are most often set against the benefits of living abroad. For example, a PhD student in mathematics at IISc Bangalore explains:

Obviously if you go outside of India you will get good progress, basically money wise, if you think then you can go outside of India, money will be more there. But the life will be, I think not that much more beautiful. Because when you live with your family when you live in your country, your top satisfaction will be there. So outside India if you go, you can get the money; fine, but then you have to sacrifice a lot of things. That is my idea. So money does not mean everything if I say, so for me living in India will be much better than going outside. When I will not be getting more money, but it is still it's fine to stay with the family, with the people I know, and miss. In India it is good to work for your country.

Among all students which were interviewed and are not planning to go abroad (6 out of 35 in-depth interviews), the prime reason for wanting to stay in India was related to their family. Staying in India means that "you're with your parents, with your family. It is like a different level of comfort and mental stability which helps you to work." A female student in physics at JNU explains that staying close to her family is so important to her that no opportunities abroad would make her change her mind about staying in India:

I don't want to leave my family members and stay away for like, lifelong. I mean, ultimately it's for them and therefore I am... If I'm not able to see my parents when they are old, then I feel there's no point in me doing anything. Ultimately, it's for them, and they are the people who are the most... who are like happiest if I do something. And if they are unable to see my happiness, then I don't think it makes any sense to me at least staying abroad away from them. So I feel nothing could change me. I mean nothing could actually stop me if I want to come back to India; any of the opportunities I get.

That moving abroad is a family decision is clearly exemplified in the opinion of a male student pursuing Masters of computer science at JNU who puts the decision about the actual move abroad in the hands on his family:

From my point of view, I am ready to go, live there, permanently but it depends on many things, on my family members. I have to take decisions on their ambitions because my mother, who has given birth to me, really doesn't want that. So I am an Indian and to go abroad just for money... and money is 
not the all. My parents is also one of the most important thing and I know one thing exactly that if you want to be happy then you have to be in your own country. ... It depends on them if they will deny me to go abroad, then surely I will not go. I will do everything by taking permission from my parents.

Those people who stayed abroad are considered to have foregone their family obligations. When talking about his friend, who intends to stay in Canada, a male student of computational and systems biology at JNU thinks that "this is a very bad practice. If your parents are here, they have cared for you, they have made everything for you in their life and now you have left them just for your opportunities in staying in some other country. Because your parents can't come to that country."

In the logistic regression, we find that if parents encourage the move, or are neutral, the fellow is more likely to be interested in going abroad. This is in line with common expectations. However, in our qualitative study we find that family support depends on how long our respondents are planning to stay abroad. While shorter stays are often encouraged, longer stays are less desirable. One respondent indicated that when planning to move abroad "for a short period, they will be happy that I am going abroad, that I will earn more money and make my financial situation better but if I will go for a long period or for a lifetime, then I don't think they are going to support me." Similarly, a Bachelor student in mechanical engineering at IIT Delhi talks about his family's feelings towards his potential move abroad:

My family is not very supportive I would say, I mean it's not about supportive, they are quite skeptical of me moving abroad due to the fact it happens very often in a society that when a person moves abroad, he shifts his residence permanently there, he doesn't come back to India and this is something which they fear, which families are afraid of. Because when you are away from your family and something very urgent happens, your family needs you very urgently, you cannot come back because of the, you know, getting visa and all this. Going through all this formal procedures. So my family is not very sure or not really keen on me moving abroad. They do have reservations, at least permanently, but they do not have these reservations sending me abroad for temporarily 5 years, 6 years. They are ok with that, but certainly not permanently.

The importance of family in the decision-making process of migration cannot be neglected as it is crucial either in a form of family support as a facilitator for the move or it inhibits people from considering new undertakings. Tight social networks involve obligations which may undermine individual economic initiatives through claims on individuals to support family and community members (De Haas, 2010). Not only that the moral support from family matters for international move, family 
is also crucial in terms of financial support. Khartik, pursuing a Master in Technology at IISc Bangalore, explains his situation:

I have two brothers, they are married. My brothers are supporting my family. This makes it fine for me to go abroad and come back and support also.

Despite the fact that family income does not have a significant effect on migration plans in our survey, several respondents in the in-depth interviews brought up the financial aspect of their decision and its link to family support. A male PhD student in chemistry from BHU-IT explained that he was already accepted for a PhD abroad but due to financial problems he could not leave. Getting financial support from his parents is not an option:

I didn't want to get money from my family. I am from a very poor family. Right now my father is a street hawker. He supported me and I am here right now. So it's really difficult to manage.

His low household income has also been an obstacle for him to obtain a loan for education because he cannot secure it with family assets. Similarly, his colleague from BHU-IT explained that lack of financial assets is the main barrier for going abroad:

The main problem is, that we don't have enough money to go there, that we have to spend the money in living there and joining their colleges. But people in India are not in that much good level that they can spend that much money so they have to go for the loans ... We have the capabilities, but we have to think about the scholarships and all that.

Safety abroad also repeatedly came up as a concern for Indian students in the interviews. The results in the logistic regression indicate that a higher rating of safety in the Likert scale has a negative effect on the chances of going abroad. People consider staying in India safer than going abroad. The qualitative results confirm this finding. Respondents often mentioned fear of being discriminated because of their skin colour, which would dissuade them from the choice of living abroad. As a Master's student of Aerospace engineering from IISc Bangalore accounted for his reasons for preference to stay in India:

I think if you are in a foreign land so there are security issues... Because you are minority right, so there is obviously a security issue, because anyhow if you are doing wrong thing, so no one will protect you. Something like that you have in your mind and this is too hard, because this is human nature. This is everywhere, even in India, where as you can see as abroad also, these kind of things. So people prefer their homeland basically. These foreign lands are just to visit things and see what they are made of and these kind of things 
...For the proper living and the proper staying as your life, so this is probably according to this, best in home land.

As most respondents do not have plans to settle down abroad for a longer time period. They focus their deliberations on their main rationale for going abroad, which is in general work or study-related. Out of 29 respondents in our in-depth interviews only 7 said they could stay abroad a bit longer while all the others strongly affirmed that they want to return to India immediately after finishing the programme they plan to attend abroad. Whether international mobility is seen only as a short-term stay abroad or as a permanent move, it will have an impact on what they consider important. In the quantitative analysis, social security and benefits did not appear to be significant in migration decisions, which is confirmed by the qualitative data. As a male student in aerospace engineering at IISC Bangalore puts his preferences:

Yes, job security definitely matters, but all this social security for me personally doesn't matter. I can't just hang on the social system, ok. But for people there, for any people basically, they will also think about social securities and also about medical systems. Medical systems, if you have a family, then medical systems are important, otherwise if you're single it doesn't affect your decision much, ok that is not a priority. But job security and all these things might be a priority. If you have seen, if I go to this company where the job security is very low, well then I'll think twice before going to that company.

For considerations of both shorter and longer mobility periods, people take these conditions into account, but indicate that job security is more important than medical insurance or pension security. A Bachelor student in chemical engineering at BHU-IT reiterates the importance of work-related factors compared to social security as a drive to move abroad:

The people in India are not going to abroad for the healthcare and the pension they are only going there because the opportunities there are high compared to India. And I don't think that any of the Indians want to go there, want to spend a lot of money to get the pension and the health care, they're only going because the opportunities there are very high. If the opportunity in India was high in the end, then I'm sure that no one would be going in the US, in Germany and other countries.

It could be expected that people, especially when they plan to move with families, choose to go to countries with good medical provisions and if they intend to move abroad for a long term it can also be expected that they would care for good pension arrangements. As such, both might not be reasons for going abroad, but 
could be conditions for choosing the destination country. Chapter 7 investigates this in more detail.

\subsection{Conclusion}

This chapter looked at the determinants to plan a move abroad in the specific situation of Indian students in sciences and engineering. We looked at the role of students' personal and family background, university-related factors, their social network and preferences for living location in their motivations for moving abroad. We find that age clearly plays a role in mobility planning, which is related to the stage in the education career. Going abroad for work straight out of the university is very uncommon. More common paths are either going abroad for advanced studies or joining a company in India at a campus placement, after which people are often sent abroad for specific assignments. Studying abroad still represents an insurmountable financial burden for most Indian students, making plans to go abroad only feasible in the situation of offered scholarship or paid positions. As very few Bachelor and Master Programmes offer any scholarships, it is unlikely that students will plan the move abroad at this stage. Our survey confirms that PhD students are most likely to plan their future career outside of India, expecting to get accepted to paid positions. This difference obviously also occurs because people who are currently in PhD programmes mostly envisage their future in academic careers, for which international experience is highly appreciated and often even compulsory, indicative of increasingly global research labour market (Ackers \& Gill, 2005). The quantitative survey as well as the in-depth interviews show us the difference in career planning between students at different universities. Especially students at universities focused on applied work, like in our case IIT Delhi and BHU-IT, are more likely to get hired by companies in India straight after their finished studies. As a result, the type of university and field of studies work as strong predictors for students' desired move abroad which is in line with other research indicating enormous differences in mobility between disciplines and scientific specialties (Ackers, 2005; Laudel, 2005). Whether a student plans a career in academia or wants to work in a company has a decisive influence on where they see themselves in the near future.

Professional aspects are confirmed to be the most prominent in the decisionmaking regarding international mobility. Our interviews highlight their importance as the following were four of most often mentioned reasons for going abroad: better possibilities for career advancement, better working and research conditions abroad, international exposure and financial benefits. It has been confirmed that students in sciences and engineering place less importance on financial aspects of 
their future jobs. The main pull factor to go abroad is the expectation of a better working environment, either because of better facilities or smoother bureaucracy. The aspects put forward by the New Economics of Labour Migration, which highlight the importance of stability and social security, as well as the aspects of amenities literature about the attractive local environment turn out to be secondary in the importance of preferences for the place of living. However, the survey shows preference variables as strong predictors for mobility plans. As expected for people who place high importance on work-related factors to be more mobile, the results equally follow our expectation that people who place higher importance on family-friendly environment and public safety prefer staying in India.

International student mobility is obviously a family decision. Parents' support is crucial for moving abroad, in moral as well as in financial terms. Very few students have any of their family members who have lived abroad, so they are mostly not able to provide them with valuable information about international opportunities. However, when parents withhold their support for moving or they are in a constraining situation, for example because of their old age or financial difficulties, this would usually undermine individual's own interests. Among all our interviewees, we find only one non-conforming student who was applying for positions abroad despite clear disapproval from his family. Normally, obligations towards family are put in the first place ahead of potential individual initiatives.

So far, we have looked at the factors determining the move abroad in a general sense. Our findings suggest that students' educational and family background, as well as financial ability matter most for their future mobility intentions. Chapter 7 further aims to establish the factors which determine the chosen location by looking only at the same sample of students who plan to move abroad. 
6.7 Appendices 


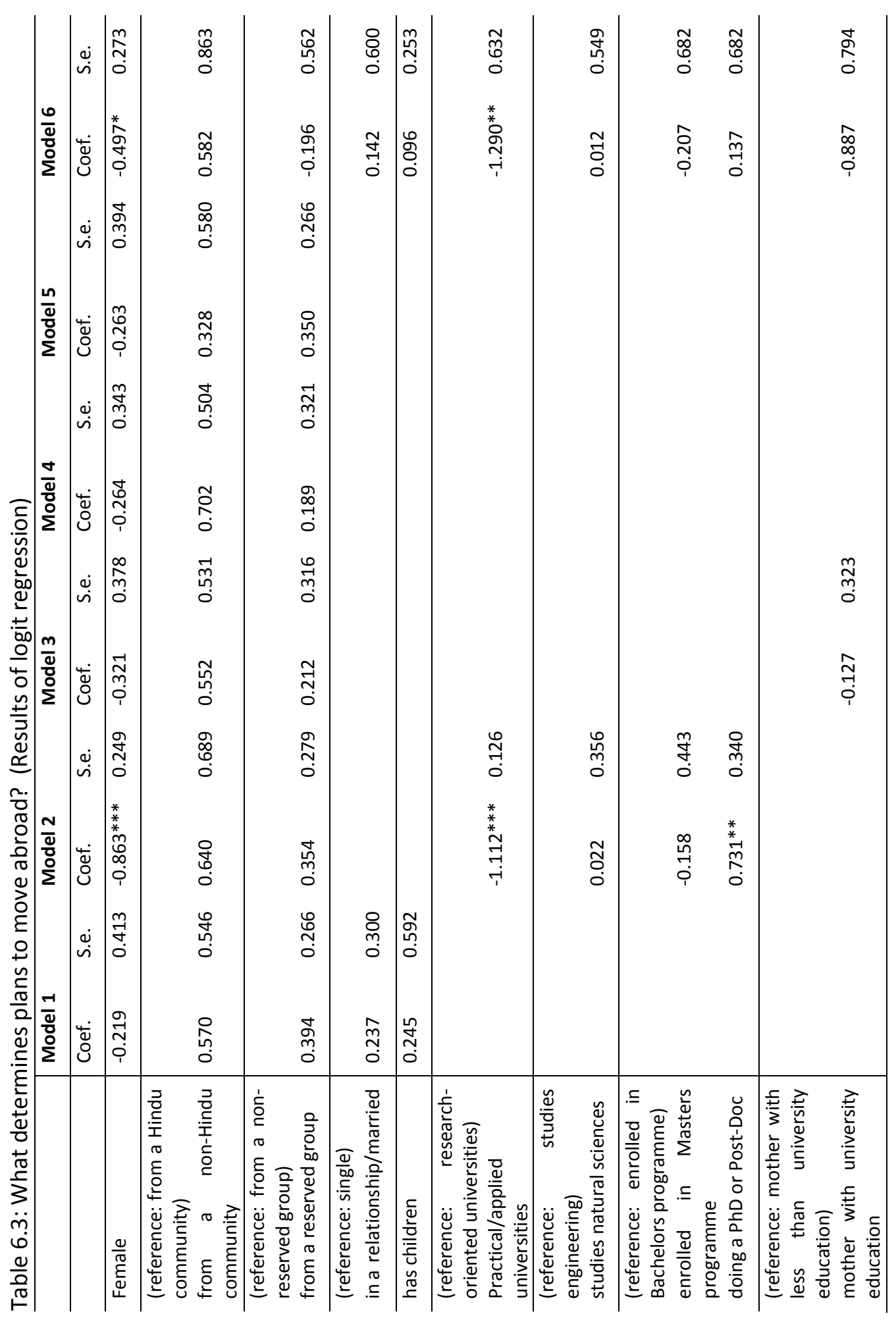




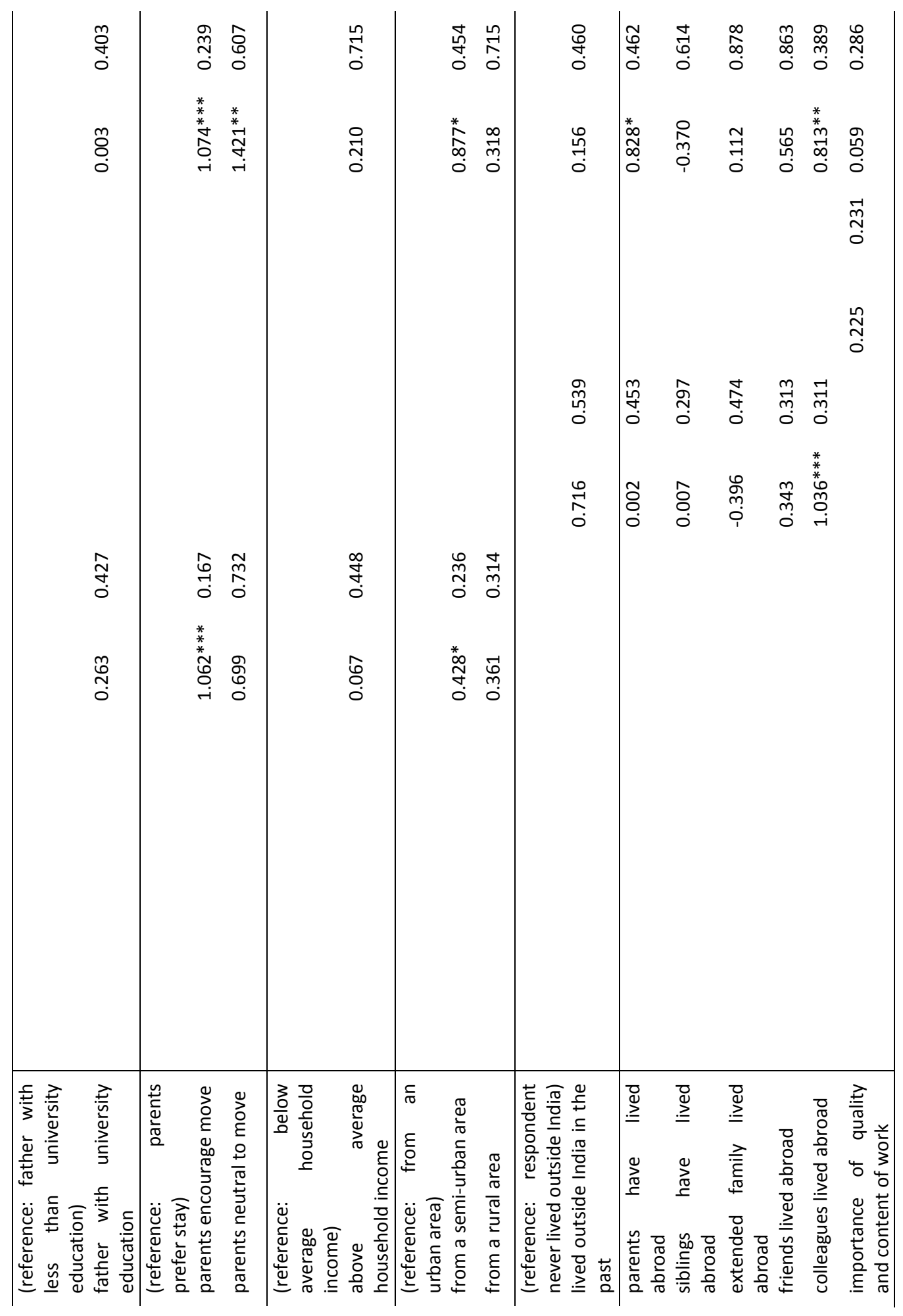

$\vec{I}$ 


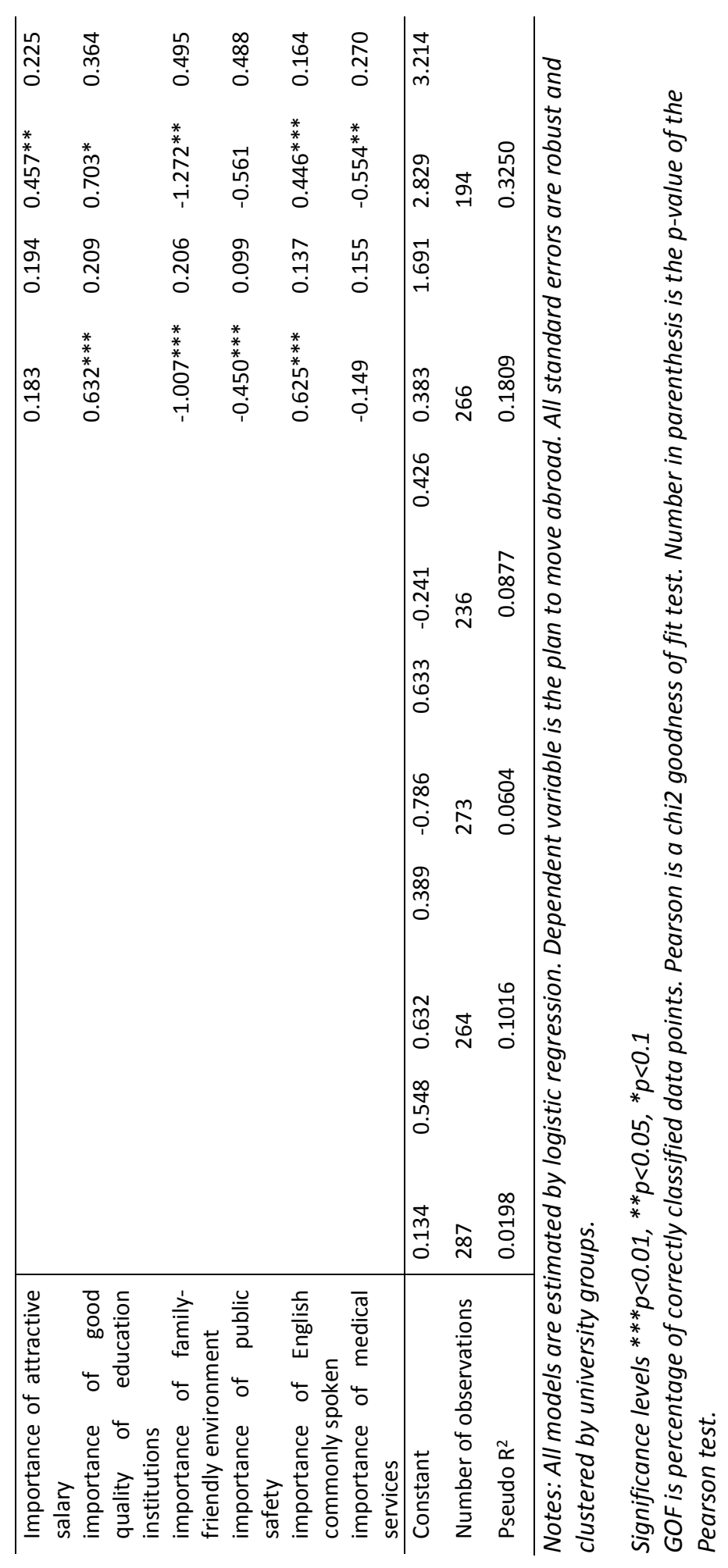




\section{What's the best place for me? Migration Location-choice for S\&E Students in India ${ }^{70}$}

\subsection{Introduction}

There is a growing agreement that international student mobility is a particularly attractive channel of highly skilled immigration, considering that a host country receives human capital which is well adapted to its labour market. Various studies show that students who studied abroad are more likely to work abroad after the completion of their studies in comparison to other domiciled students (De Grip et al., 2009; Findlay et al., 2005; King et al., 2004; Tremblay, 2002; Wiers-Jenssen, 2008). Student migration is construed as a form of knowledge migration also by industrialized countries which are changing their policies in order to become more attractive for students and highly skilled migrants. After the comparison of different policy dimension in selected European countries and the United States, chapter 3 of this thesis concludes that European migration policies have become progressively more favourable towards the admission of highly-skilled workers in recent years and have in certain aspects become more attractive than the $\mathrm{H}-1 \mathrm{~B}$ visa in the United States. Specifically advantageous rules were adopted for young migrants and for former students, which are lured to host countries as "probationary migrants". However, they have had different levels of success in reaching the expected higher figures of skilled immigrants. As one of the interests of this research is to find out whether continental European countries have successfully joined the global competition for talent, this chapter compares the perceptions potential migrants have about these countries as opposed to the views about traditional immigration countries. The objective is to find out whether determinants of migration to continental Europe differ from determinants of migration to the United States and the other Anglo-Saxon countries.

Chapter 7 follows up on the previous chapter by looking only at the selection of students who would like to go abroad and observing their destination preferences. Firstly, the geography of Indian migration, globally and with focus on Europe and North America specifically is shortly described. Secondly, we present previous research about student choices on international mobility. Thirdly, we analyze the data from the survey at five Indian universities and observe if students differ when compared by preferred destination country in any of the personal and background

\footnotetext{
70 Paper available as: Hercog, M. \& Van de Laar, M. (2013). What's the best place for me? Location-choice for S\&E students in India. UNU-MERIT Working Paper Series 2013-066.
} 
factors as well as in consideration of influencing factors on migration decision. This analysis is quantitative, comparing descriptive statistics as well as performing multinomial logit regressions. In addition, we reflect on the results of the quantitative analysis by the investigation of in-depth interviews with a selected group of students. The chapter concludes with propositions for possible policy interventions that would function as incentives to migrate to a certain country.

\subsection{Geography of overseas Indians}

With an estimated 11.4 million people in 189 countries around the world, Indians abroad constitute one of the largest and most established diasporas around the world, as already mentioned in chapter 6 (Ackers \& Gill, 2005). Map 7.1 shows the distribution of Indians living outside India. It is evident from the map that Indians are dispersed throughout the world with some areas of concentration.

Map 7.1: Overseas Indians in the World

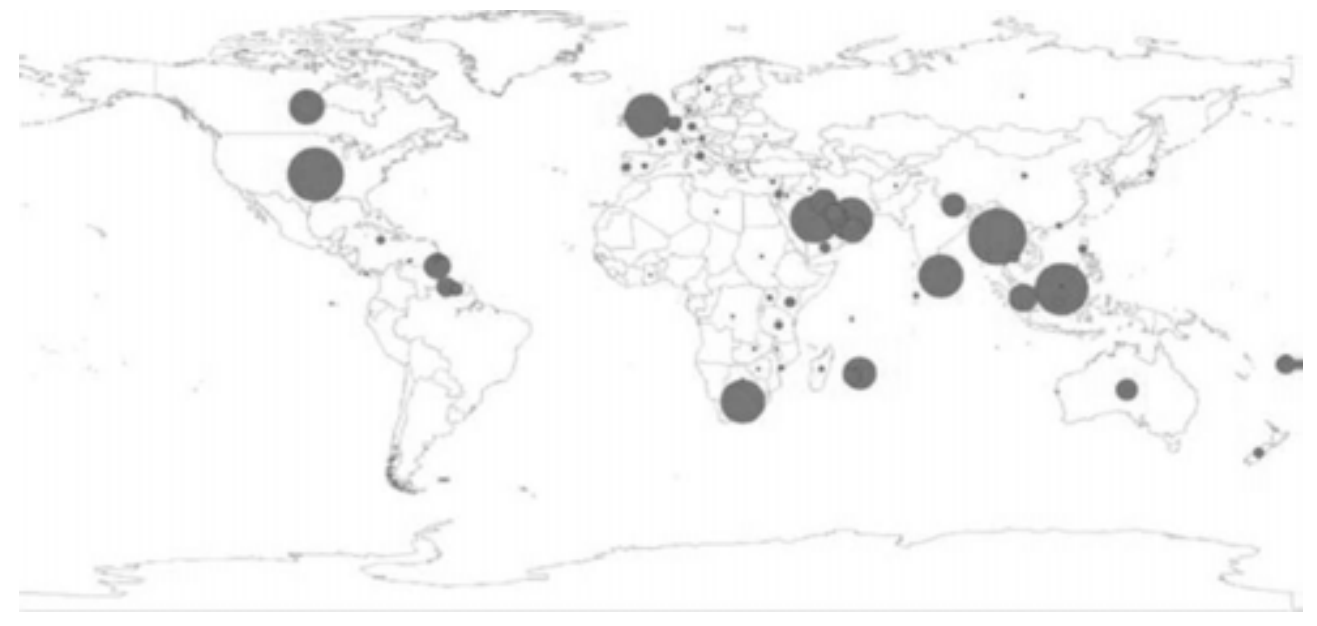

Source: Vezzolli and Lacroix 2010, pp. 9

Note: Circle area is proportional to the number of overseas Indians. The largest circle corresponds to 2000000.

Even though this thesis focuses on highly-skilled migrants, it is important to stress that at present, the bulk of Indian migration is low-skilled in nature with skilled workers representing approximately 20 percent of the total migrant flows from India (Chanda \& Sreenivasan, 2006). Given that the majority of emigration from India is low skilled, it is not surprising that in the annual labour outflows for 2009, Saudi Arabia is the major receiving country (281,110 workers per year from India), followed by the United Arab Emirates (130,302), Oman (74,963), Qatar $(46,292)$ 
and Kuwait $(42,091)$, countries with high demands for low-skilled workers (MOIA, 2010, p. 51).

Since highly-skilled Indians concentrate in a few industrialized destination countries, we look in more detail at the size of Indian migrant communities in the OECD countries. Figure 7.1 shows an increase in immigration flows from India to major OECD receiving countries. While the United States and the United Kingdom continue receiving the largest numbers of Indian migrants, a substantial increase is also noticeable for Australia and to a lesser extent for Canada, which had a peak in immigration in 2005 but has now again reached a similar level as previously.

Figure 7.1: Immigration flows of Indian-born immigrants (aged 15 and older) in the main OECD destination countries, from 1998 to 2009

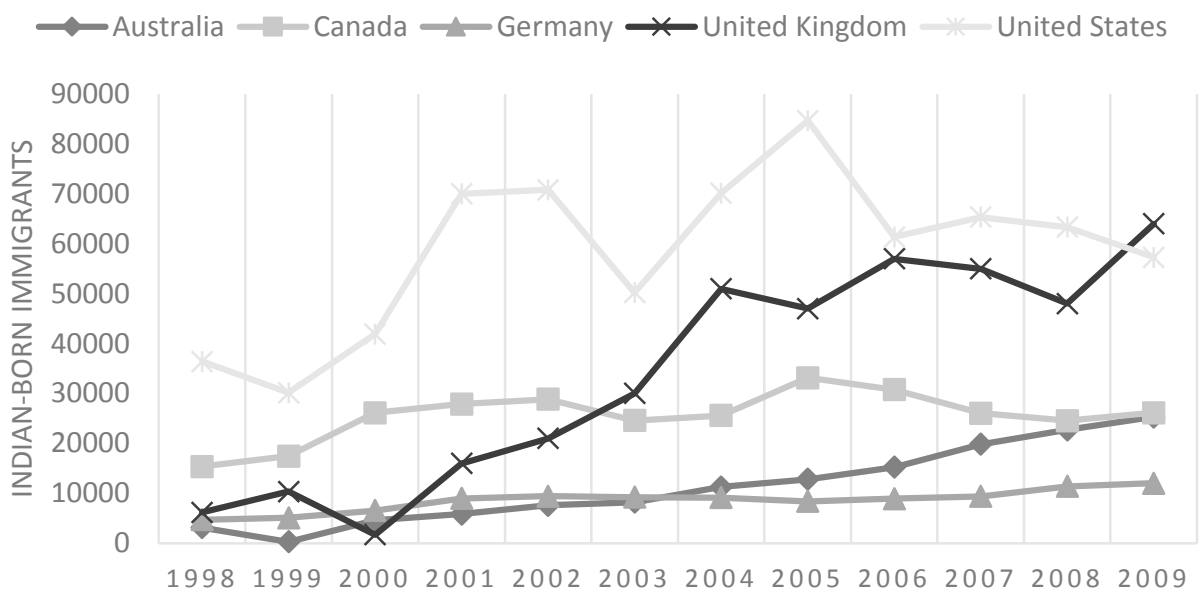

Source: Database on Immigrants in OECD Countries (DIOC), OECD.stat, extracted on January 7, 2012

Among the OECD countries, Indians are predominantly concentrated in only a few countries (Table 7.1 and Figure 7.2). This concentration is even stronger for highlyeducated Indian migrants; 92.3 percent of all Indian migrants with tertiary education reside in only three countries: the United States, the United Kingdom and Canada. The United States by itself hosts 66.4 percent of all tertiary educated Indian migrants. Especially notable for Indians in the United States is their skills composition. 69.1 percent of Indian-born immigrants in the United States have completed tertiary education. Indians are also the most prevalent among the $\mathrm{H}-1 \mathrm{~B}$ visa beneficiaries, representing 48 percent of reported beneficiaries for this visa, specifically designed for specialty occupations (USCIS, 2010). Skills composition in Australia and Canada is also leaning towards highly-educated migrants, with 53.3 percent and 40.7 percent of Indian migrants holding tertiary education, 
respectively. In comparison, the overall skills structure of Indian migrants in Europe is dominated by migrants with lower levels of education. In the United Kingdom and continental European OECD member states, half of Indian-born migrants hold only primary education or lower. Only 21.5 percent of Indian migrants in the European OECD countries, without counting the United Kingdom, hold tertiary education.

Table 7.1: Distribution of Indian-born migrants in major OECD destination countries by educational level

\begin{tabular}{l|lll|l}
\hline Country of destination & ISCED 0/1/2 & ISCED 3/4 & ISCED 5/6 & All levels of education \\
\hline United States & $12.8 \%$ & $18.1 \%$ & $69.1 \%$ & 958,057 \\
Canada & $32.0 \%$ & $27.3 \%$ & $40.7 \%$ & 306,860 \\
Australia & $18.8 \%$ & $27.9 \%$ & $53.3 \%$ & 79,731 \\
United Kingdom & $51.3 \%$ & $15.4 \%$ & $33.3 \%$ & 398,753 \\
Other OECD European & $49.7 \%$ & $28.8 \%$ & $21.5 \%$ & 114,397 \\
Other OECD71 & $14.2 \%$ & $36.8 \%$ & $49.0 \%$ & 20,828 \\
& & & & \\
\hline OECD - Total & 497,917 & 381,411 & 996,813 & $1,876,141$ \\
& $(26.5 \%)$ & $(20.3 \%)$ & $(53.1 \%)$ & $(100 \%)$ \\
\hline
\end{tabular}

Levels of International Standard Classification of Education: ISCED 0: pre-primary education, ISCED 1: primary education, ISCED 2: lower secondary education, ISCED 3: upper secondary education, ISCED 4: post-secondary non-tertiary level of education, ISCED 5: tertiary type education, ISCED 6: advanced research qualification.

Source: DIOC, OECD.stat, extracted on September 26, 2010

${ }^{71}$ Other OECD countries are New Zealand, Japan, Turkey and Mexico. 
Figure 7.2: Indian-born immigrants in major destination countries by educational levels

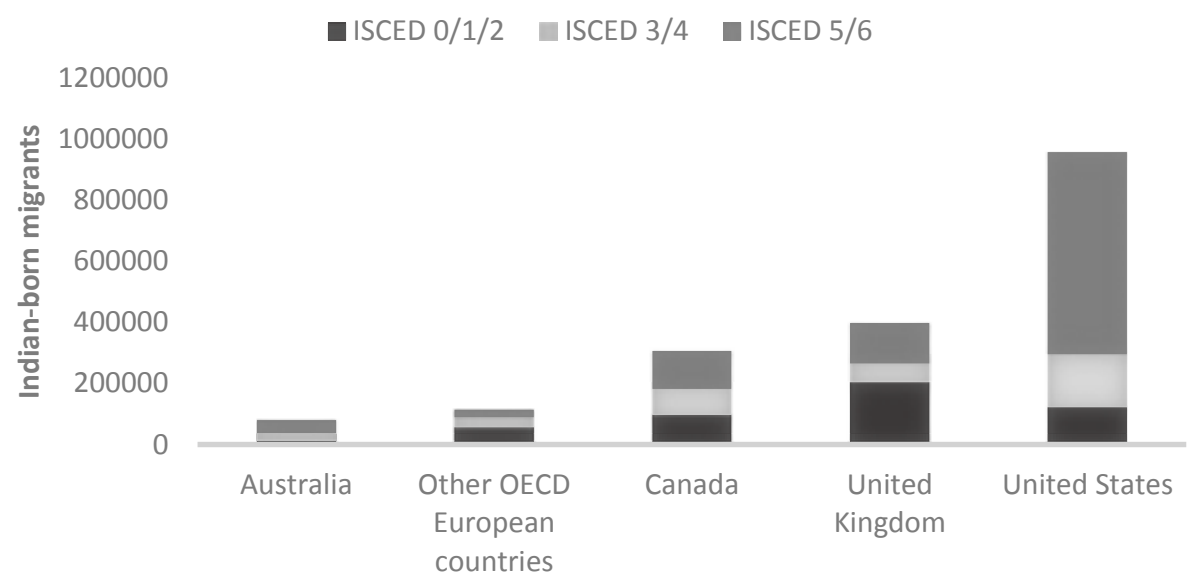

Countries of destination

Source: Database on Immigrants in OECD Countries (DIOC), OECD.stat, extracted on September 26, 2010

Looking at the Indian population in Europe in closer detail, it is clear from the above presented numbers that the United Kingdom accounts for two thirds of the Indianborn migrants in Europe. The Annual Population Survey in the United Kingdom assessed the stock of Indian-born migrants for 2011 to be 729,000, an increase from 502,000 in 2004 (ONS, 2011). The inflow of Indians in the United Kingdom has been substantial ever since the independence of India, and has recently further increased. Table 7.2 shows immigration inflows to the United Kingdom for 2001 with 15,957 people with a previous residence in India immigrating annually; with a continuous increase for each subsequent year, this number had increased to 51,849 by 2006. An increase in immigration flows from 1998 till 2009 is noticeable for all observed countries, especially for Spain, Sweden, Italy, Denmark and the Netherlands. Immigration of Indians to Spain increased twenty fold within this timeframe, predominantly with low-skilled migrants (Table 7.2). Although the overall numbers of Indian migrants in Europe are still low and represent almost negligible shares on the global scale, there is a clear trend of growth.

Migration of Indians to the European continent remained relatively peripheral and transitory until the end of the Second World War. It was only in the late 1950s and 1960s that Indian nationals started to move to Europe on a more substantial and permanent basis. Giri (2011) identifies this as the first wave of immigration of Indian citizens to Europe, which mainly consisted of movements of indentured labourers from former colonies to Europe. The second wave of Indian migration to 
Europe, referred to as the "new diaspora", occurred mainly during the European re-construction boom in the late 1960s. During this period a considerable number of labour migrants of Indian origin decided to settle in Europe. Whereas most migrants moved to the United Kingdom, other major destination countries included Germany, The Netherlands, France and Belgium. The third wave of Indian migration to Europe was in the 1980s, following the restrictive immigration rules of European countries with respect to entry and residence of semi- or unskilled third-country nationals. This changed the dynamics of migration as a continuous stream of highly skilled professionals, such as doctors, engineers and scientists arrived from the Indian sub-continent. A fourth wave of immigration to Europe took place in the 1990s, consisting mainly of Indian IT software specialists and has continued until today. 

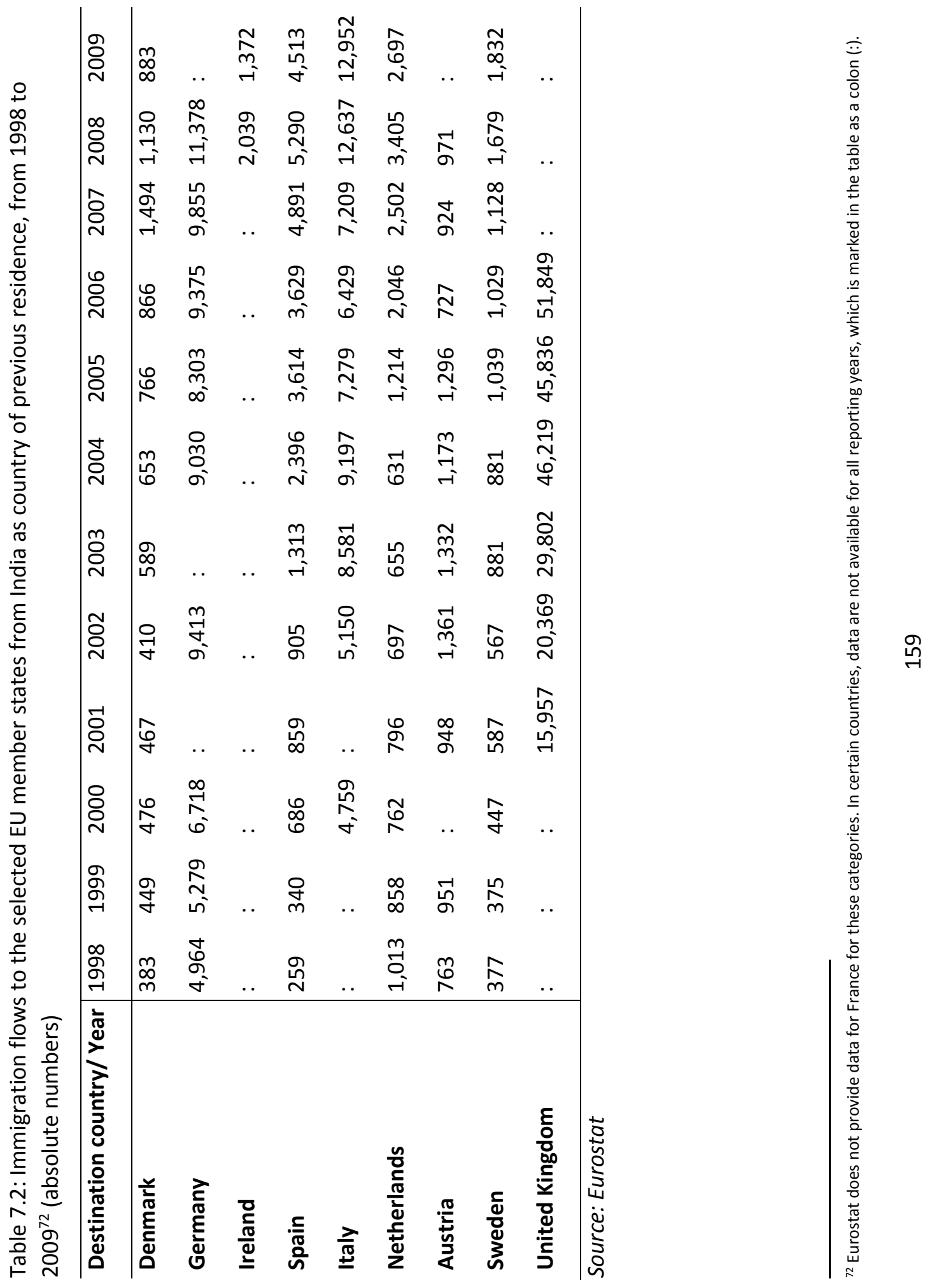
Also immigration to the United States started picking up from the 1970s onwards. In the 1960s, only 12,296 Indian-born individuals were residing in the United States. The Indian-born population grew to 450,406 in 1990 and had reached a total population of more than one million people by 2000 . In 2005, the Indian-born population in the United States was close to 1.5 million (Desai, Kapur, McHale, \& Rogers, 2009). Figure 7.3 shows for the past five decades a steep increase in a number of people obtaining legal permanent residence in the United States, for persons with their last place of residence in India. Between 2000 and 2009, 590,464 Indians became legal permanent resident in the United States. Moreover, the annual numbers remain at a high level in the last years: 59,728 in 2008, 54,360 in 2009 and 66,185 in 2010, which is close to 5 percent of all the permits issued in these years in the United States (USDHS, 2011).

Figure 7.3: Number of people obtaining legal permanent resident status in the United States from India as country of last residence, from 1960 to 2009

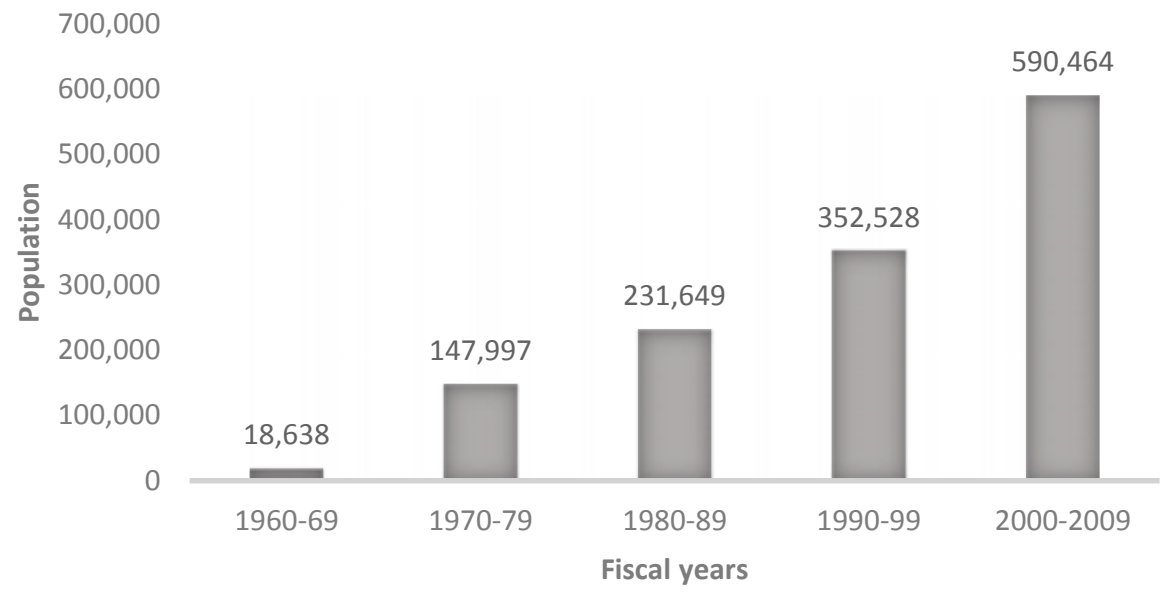

Source: United States Department of Homeland Security, 2011; Author's analysis

\subsubsection{Geography of student mobility}

The United States of America is also the main destination for Indian students, attracting 51.2\% of all Indians who studied abroad in 2008 (94,664 in absolute numbers) (see Figure 7.4). The other main countries of destination are Australia $(26,520)$, United Kingdom $(25,901)$, Canada $(10,357)$, New Zealand $(5,426)$, Russian Federation $(4,314)$ and Germany $(3,644)$, while the remaining destination countries only draw minor shares. Whereas the top three destinations, the United States, the United Kingdom and Australia attract 79.6 percent of Indian students enrolled abroad, we can observe that increasing numbers of Indian third level students have been moving to other destinations such as Canada and New Zealand, but also to 
continental European countries like Germany and France (OECD, 2010d). Figure 7.5 illustrates this growth from 2000 till 2011 for the main countries of destination (until 2008 for the United States and Australia since this information is not available for the year 2011). All of them experience upsurges in enrolments of Indian students.

Figure 7.4: Indian students studying abroad in tertiary education in a given country of residence as a percentage of all Indian citizens studying abroad (2008) in all reporting countries

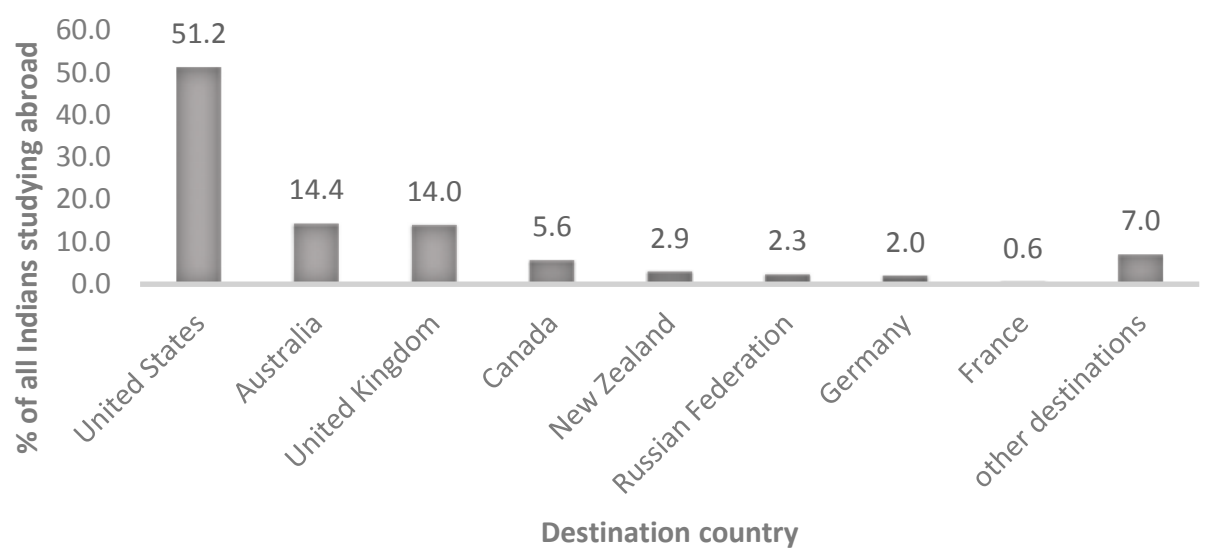

Source: (OECD, 2010c), Author's analysis

Figure 7.5: Indian students enrolled abroad in a given country of destination, years 2000, 2004, 2008 and 2011

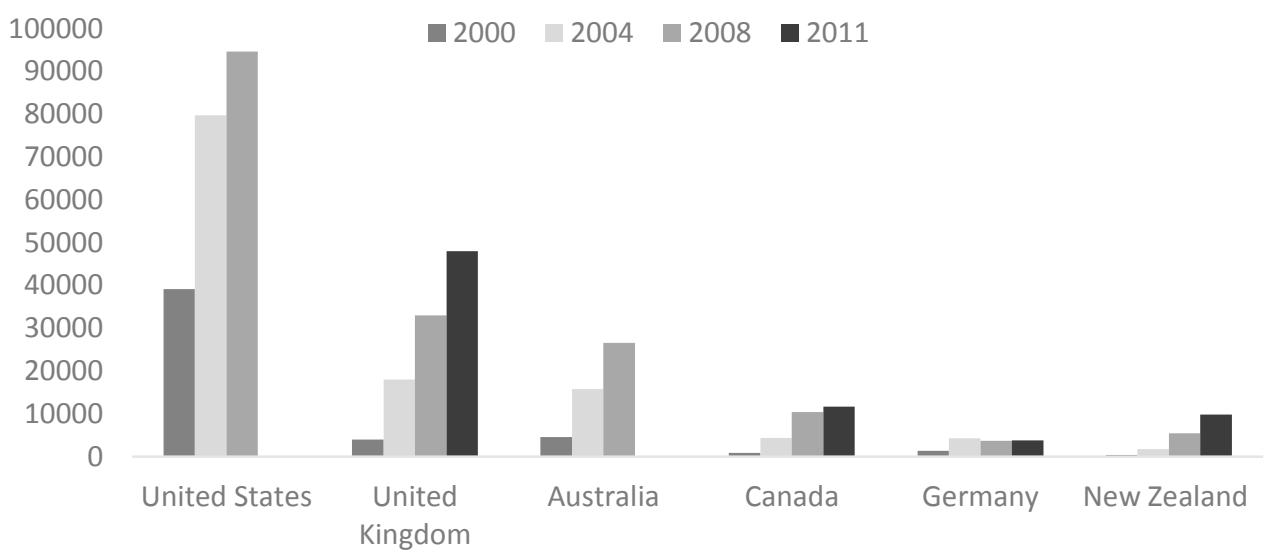

Source: The UNESCO/OECD/EUROSTAT (UOE) database, http://stats.oecd.org, accessed 25 February 2014, Author's Analysis

Note: No data is available for the United States and Australia for the year 2011 


\subsection{Related previous research}

Increased student mobility has not gone unnoticed with the academic research. The majority of studies has put more emphasis on the demand side, observing educational institutions and from a marketing perspective suggesting improvements to the universities in the offer to international students (Binsardi \& Ekwulugo, 2003; Mazzarol, 1998). Already the early work on student mobility sees the university offerings not only in terms of core educational service, but also in combination with secondary/auxiliary offerings of tangible and intangible attributes (Grönroos, 1978, 1994; Levitt, 1980). However, these studies have not touched upon the influence of non-educational factors such as personal reasons and or the country image effect. Cubilo, Sanchez and Cervino (2006) make an overview of the main higher education choice literature and it is noticeable that for a majority of previous studies non-educational factors are not taken into account. Findings of the papers mentioned in this overview expose the importance of university and programme reputation (Lin, 1997; Mazzarol, 1998; Peng, Lawley, \& Perry, 2000; Price, Matzdorf, Smith, \& Agahi, 2003; Qureshi, 1995; Soutar \& Turner, 2002) the need of segmentation of prospective students and programme suitability (Hooley \& Lynch, 1981), wide offer of courses, cost of attendance, financial aid (Ivy, 2001; Qureshi, 1995), teaching quality (Lin, 1997; Price et al., 2003; Soutar \& Turner, 2002) and internship opportunities (Lin, 1997).

Only a few papers look beyond the effects of education services on student mobility choice. Srikatanyoo and Gnoth (2002) are among the few authors which focus on the country image effect on the decision making in international tertiary education. They develop a conceptual model for students' choice of international tertiary education destination, in which country image is placed on a par with institution image and programme evaluation. They claim the country image directly influences students' attitudes towards its academic institutions in either a positive or a negative way. A favourable country image may create positive beliefs about the quality of institutions as well as shatter the success of individual educational institutions. Bourke(2000) sustains this claim in her empirical investigation on international students in Ireland and pre-departure students in Malaysia. Educational reputation of a country proved to be a decisive factor in the choice of a destination. Their fieldwork testifies that intending students first select a host country and then choose an educational institution. Binsardi and Ekwulugo (2003) also identify in their study among international students in the UK that it is both, educational and country-related factors which influence their decision for location. Respondents in the survey ranked the ease of immigration procedures and university admissions right after the importance of educational standards. The ease of finding employment during and after the studies was positioned in the third 
place and the cost of living, safety and culture in the fourth place. Nonetheless, contrary to above mentioned studies Peng et al. (2000) conclude that brand image still has the strongest effect when they model effects of country, corporate and brand images on evaluation of educational services.

Although decisions concerning student mobility are not necessarily equivalent to those of labour migration, we can make a number of parallels also from the research on determinants of destination choice for highly-skilled migrants. Determinants of migration has traditionally been researched from the perspective of neoclassical economic migration theories (Harris \& Todaro, 1970; Sjaastad, 1962; Todaro, 1969), which analyze migration decision in terms of evaluating costs and benefits of migration. An individual is seen as a utility maximizing agent who will migrate when one expects a higher utility in a different location, net of migration cost. Individuals compare locally expected earnings with their expected earnings at different destination countries. Economic literature emphasizes the economic aspects of the decision-making and posits that people migrate to areas with a higher wage level. Especially when international students are seen as 'probationary immigrants' (Millar \& Salt, 2007) who take student mobility as a stepping stone towards later labour migration, an assumption can be made that career prospects in the host country play a role already at the decision about student mobility.

Among the few papers attempting to explain the country choice determinants by demonstrating the difference in migration decision with respect to geographic areas, papers by De Grip, Fouarge, and Sauermann (2009) and Constant and D'Agosto (2008) look into the determinants of country choice for European science and engineering graduates and for Italian scientists and researchers, respectively. De Grip et al. find out that among European science and engineering graduates' wages matter only for migration within the European Union but not for migration to Anglo-Saxon countries, which attract people for higher R\&D intensity rather than prospects for higher wages. Differences between graduates' destinations are found also in terms of disciplines, namely graduates with a life science degree preferring Anglo-Saxon countries. Previous migration experiences of graduates and of their parents are predictors for migration to other European countries, but not for migration to the Anglo-Saxon countries. Similarly, people in relationships and older graduates are more likely to migrate to another European country (De Grip et al., 2009). The study findings by Constant and D'Agosto show that gender, education and working experiences from abroad, the field of specialization, motives for migration, and duration of residence abroad can predict the country choice. For example, men are less likely to go to the UK than women. People with a PhD from outside Italy are more likely to go to the UK than other EU countries and those with some working experience from outside Italy are less likely to go to the US. In 
addition to the above, the lack of research funds in Italy determines the choice of going to the US (Constant \& D'Agosto, 2008).

Mahmood and Schömann (2003a) contribute to the debate on location-choice preferences by acknowledging that staying in a home country is increasingly a viable option also for many highly-skilled people from developing countries. They look at the determining factors influencing selection of alternative countries for ITgraduates in Pakistan (2003aa) and India (2003ab), respectively, and compare the factors with the option of staying in a home country. When comparing between alternative foreign destinations, it shows that the United States and Canada have an advantage over Germany when looking at the impact of self-employment, highcareer positions, social networks and residence permits. Economic aspects prove to be more important for migration decisions than institutional and socio-political factors.

Based on the literature reviewed and on the review of migration theories presented in Chapter 2, we identify determinants influencing international mobility, which we measure using the dataset compiled for the specific purpose of studying location preferences. For more information on the survey instrument and the sample, please review chapter five and its appendices. The analysis presented in this chapter looks only at those students in the collected dataset who have expressed the intention to move abroad and analyses their choice of preferred country. Several questions in the survey address the decision-making with respect to the location choice.

\subsection{Empirical results}

In our sample of science and engineering university students in five Indian universities who reported a plan of going abroad, we find a dominance of preference for going to the United States, similar to the general distribution of Indian students abroad. Respondents could choose several countries which they consider as their potential destination (Figure 7.6). Most respondents in our sample chose the United States as preferred destination, followed by the United Kingdom as second most often chosen preferred destination. Among people who answered they would consider going to a continental European country, the most common answer was that they would want to go to Germany, followed by France, Switzerland and The Netherlands. If they chose the option of another European country, they were asked to specify which European countries they would choose by having space to provide more options. Germany was mentioned 72 times, France 28 times, Switzerland 19 and The Netherlands 15 times. 
Figure 7.6: What destinations would you consider if you move abroad?

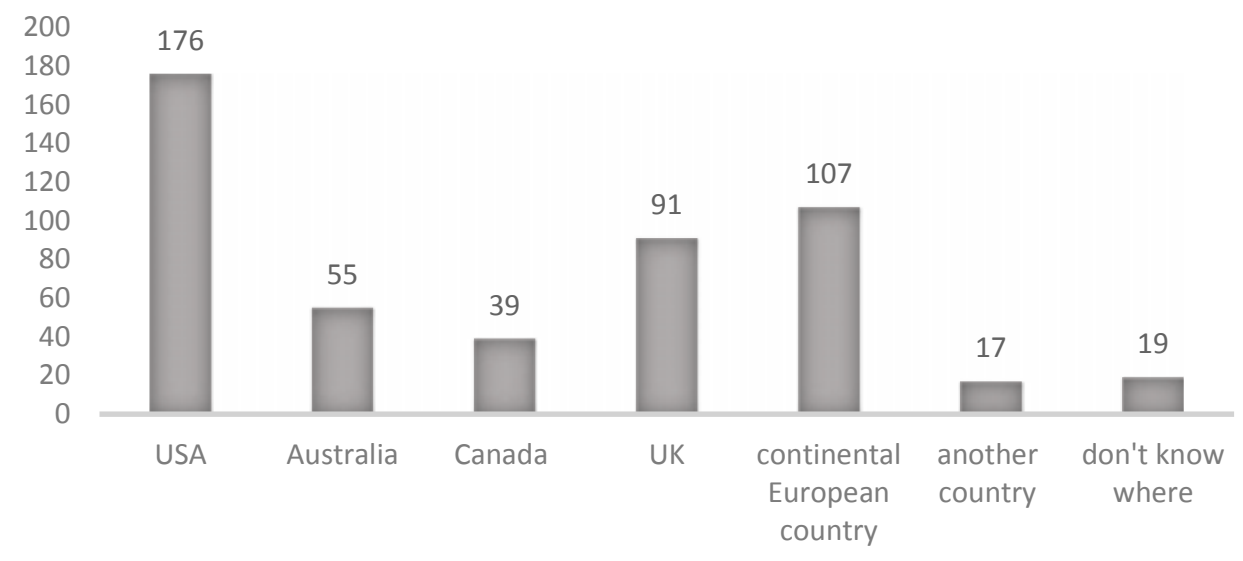

Note: Multiple answers possible, $N=311$

In the subsequent question, respondents were asked to name only one country as their first choice if they were to move abroad in the following five years. Behavioural intentions are considered good predictors of actions if they measure somewhat specific behaviour in a restricted time span in which an individual has a lot of freedom of choice (Van Dalen \& Henkens, 2008). The question we address to the respondents is therefore purposely specific about their future plan regarding location choice within an exact time frame (five years). As shown in Figure 7.7, it is remarkable to note that more than half of our respondents (52.7 percent) choose the United States of America as their first option for moving abroad. Interestingly, the second most often mentioned country is Germany, however only 13 percent of students mentioned it as their first choice. The other most frequently mentioned countries are the United Kingdom, Australia and Canada. As expected from the general patterns of Indian highly-skilled migration, preferences for a destination country from our sample clearly show that some countries have an obvious advantage in attracting the Indian skilled population. From the presentation of general statistics of Indian highly-skilled mobility, it is clear that the European countries lag far behind the United States, which has had over a million of admissions of Indian citizens in each year since 2007, with only a small decrease in 2009 (USDHS, 2012). In our sample, however, continental European countries are mentioned rather often as the first preference. Interestingly, Germany is picked more often than the United Kingdom or Australia, which in overall trends of Indian international student mobility come second and third after the United States. Other continental European countries were also picked in 22 cases as the first option out of 262 answers. There are a number of countries clustered in this group, with Switzerland, The Netherlands and France being mentioned by more respondents. 
This outcome offers some positive indications with respect to competitiveness of European countries in the competition for skilled migrants. In the next section we take a closer look at those respondents which pick Europe as their preferred foreign destination. We observe whether there are any apparent differences between those students who choose the United States compared to those that choose any of the other Anglo-Saxon countries or European countries.

Figure 7.7: What would be your top destination country in case you want to move in the following 5 years?

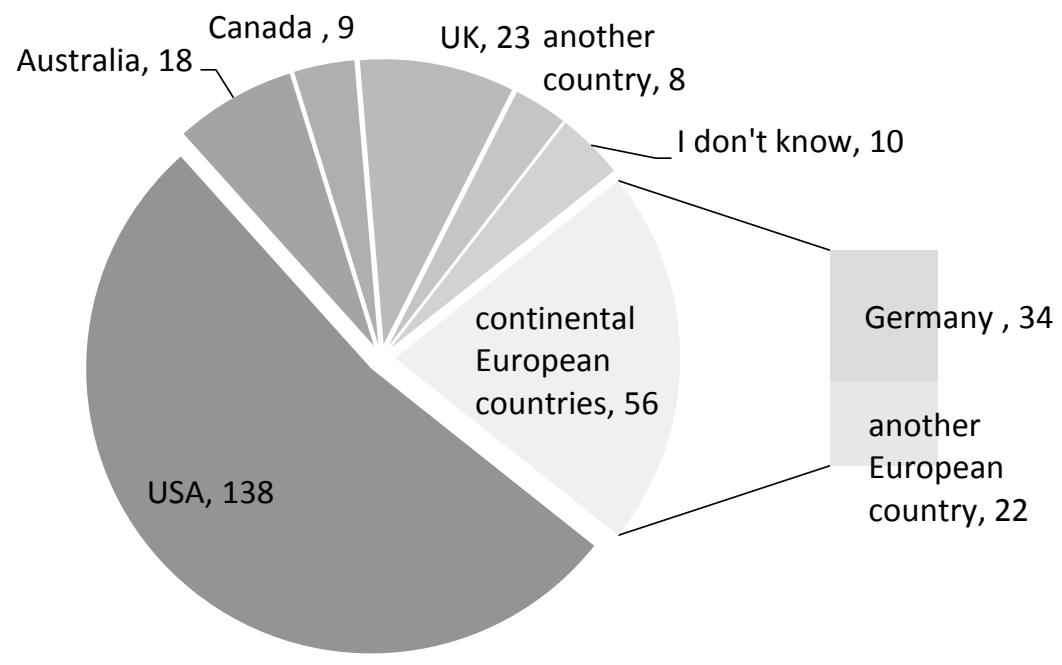

One answer possible, $N=262$

The in-depth interviews with the selected number of respondents show the complexity of geographic decision-making. When given the opportunity to elaborate on their future plans, only 14 out of 35 respondents had only one country as a clear answer to their preferred country of destination. In all the other cases, they were weighing between more options and the given reasons for different locations will support the understanding of results obtained from the quantitative data.

\subsubsection{Comparison of respondents by preferred destination}

In order to provide an assessment whether respondent differ in personal and other background factors by a chosen destination country, we divide the respondents to our question to which country they like to move in three groups: those that prefer the United States, those that prefer other Anglo-Saxon countries and those that 
prefer continental European countries. Migration choices are pulled together in three mentioned groups according to relevant criteria determining migration patterns. The United States' universities and high technology companies have worked as a magnet for Indians for decades, leading to a strong migration network. As a traditional immigration country, a vast majority of skilled Indians are exclusively interested in migrating to the United States of America. In the second group are the other Anglo-Saxon countries, namely the United Kingdom, Canada, Australia and New Zealand. They have been historically open to immigrants; they are all English-speaking countries, and linked to India with colonial history. The four named Anglo-Saxon countries all have a supply-driven immigration policy for the highly skilled, where applicants for skilled migration are selected based on their attributes and capabilities. Australia and Canada were the first to introduce pointsbased system as part of their immigration policy already in the 1980s, New Zealand followed in 1991 and the UK introduced of a similar system in 2002. As the third group, of particular interest for this research, the European continental countries are pulled together in one group. These countries differ from all the Anglo-Saxon countries in several aspects. First of all, the fact that English is not the main language spoken in these countries leads to a language barrier, which might make these countries less attractive for English-speaking students. Second, these countries miss historical traditional links with India and due to smaller inflow of migrants in the past they also lack migrant networks which could facilitate migration and inspire potential migrants to consider a specific foreign country. However, with changes in immigration and higher education policies in order to attract highly skilled migrants from third-countries and with a growing agreement that high-skilled immigration is desirable for Europe (Kahanec \& Zimmermann, 2011), we have a special interest to observe how Europe is perceived by potential migrants and whether personal and structural background factors differ between respondents who chose a certain destination preference.

From this analysis we omit those respondents who did not specify a preferred destination country or chose a country which does not fit in the three geographical categories. The selection under the category of "other countries" ranges from mentioning specific countries in Asia to a description of the favourite place in terms of offering specific qualities, for example good and competitive research. As very few answers fall in this category and since there is no commonality within the category, we decided to omit the responses from this part of the analysis of location choice.

We are interested to observe how the various factors of interest of the respondents differ by countries chosen as the first option for migration (see Table 7.3). Are students who prefer European countries different from those who chose any of the 
Anglo-Saxon countries? We use the Pearson's Chi-square test to test whether people with different personal and structural background characteristics also differ in frequency with which they express preferences for migration destinations. ${ }^{73} \mathrm{We}$ further look into issue if any of the dimensions would have an effect in terms of choosing a particular group of countries. To find the level of statistical significance linked with a single cell value, we conduct a residual analysis.

Table 7.3: Comparison of the S\&E students by main characteristics according to preferred country (in percentages)

\begin{tabular}{|c|c|c|c|c|c|}
\hline & & USA & $\begin{array}{l}\text { Anglo- } \\
\text { Saxon }\end{array}$ & European & Total \\
\hline Total & & 138 & 52 & 56 & 246 \\
\hline$N=246$ & & 56.10 & 21.14 & 22.76 & $100 \%$ \\
\hline \multicolumn{6}{|c|}{ Personal characteristics } \\
\hline Gender & Male & 72.55 & 73.33 & 80.43 & 74.61 \\
\hline $\begin{array}{l}N=193 \\
\mathrm{Pr}=0.579\end{array}$ & Female & 27.45 & 26.67 & 19.57 & 25.39 \\
\hline Age & 22 and younger & 26.80 & 36.59 & 21.74 & 27.72 \\
\hline $\mathrm{N}=184$ & Between 23 and 26 & 35.05 & 39.02 & 43.48 & 38.04 \\
\hline $\operatorname{Pr}=0.409$ & 27 and older & 38.14 & 24.39 & 34.78 & 34.24 \\
\hline Community & Non-Hindu & $20.65 *$ & 35.90 & 30.95 & 26.59 \\
\hline $\begin{array}{l}N=173 \\
\operatorname{Pr}=0.149\end{array}$ & Hindu & $79.35^{*}$ & 64.10 & 69.05 & 73.41 \\
\hline Reserved status & Reserved & 16.33 & 11.90 & 23.26 & 16.94 \\
\hline $\begin{array}{l}\mathrm{N}=183 \\
\mathrm{Pr}=0.367\end{array}$ & Non-reserved & 83.67 & 88.10 & 76.74 & 83.06 \\
\hline Relationship & Single & 79.00 & 69.77 & 74.42 & 75.81 \\
\hline $\begin{array}{l}N=186 \\
\operatorname{Pr}=0.483\end{array}$ & $\begin{array}{l}\text { Married/in a } \\
\text { relationship }\end{array}$ & 21.00 & 30.23 & 25.58 & 24.19 \\
\hline Children*** & No children & 72.73 & $93.02 * * *$ & 65.91* & 75.81 \\
\hline $\begin{array}{l}N=186 \\
\operatorname{Pr}=0.007\end{array}$ & Children & 27.27 & $6.98 * * *$ & $34.09 *$ & 24.19 \\
\hline \multicolumn{6}{|c|}{ University characteristics } \\
\hline Type of university & Research-oriented & 84.07 & 87.50 & 83.67 & 84.76 \\
\hline $\begin{array}{l}\mathrm{N}=210 \\
\mathrm{Pr}=0.833\end{array}$ & Practical/applied & 15.93 & 12.50 & 16.33 & 15.24 \\
\hline Study field & Natural sciences & 36.73 & 35.56 & 48.89 & 39.36 \\
\hline $\begin{array}{l}\mathrm{N}=188 \\
\mathrm{Pr}=0.322\end{array}$ & Engineering & 63.27 & 64.44 & 51.11 & 60.64 \\
\hline Level of studies** & Bachelor & 18.95 & 14.29 & $29.55^{*}$ & 20.44 \\
\hline $\mathrm{N}=181$ & Masters & 29.47 & $50.00 * * *$ & $18.18^{* * *}$ & 31.49 \\
\hline $\operatorname{Pr}=0.021$ & PhD and Post Doc & 51.58 & $35.71^{*}$ & 52.27 & 48.07 \\
\hline Average grade & Lower than first class & 25.84 & 17.07 & 24.39 & 23.39 \\
\hline $\mathrm{N}=171$ & (below $\mathrm{B}+$ ) & 74.16 & 82.93 & 75.61 & 76.61 \\
\hline $\operatorname{Pr}=0.539$ & First class $(A+, A, A-)$ & & & & \\
\hline
\end{tabular}

73 The test of independence measures whether paired observations on two variables are independent of each other. Since our sample is small, we also use the Fisher's exact test for some of the variables. We further assess with a two-tailed test whether any of the categories of the selected values have an effect in terms of destination choice. 


\begin{tabular}{|c|c|c|c|c|c|}
\hline $\begin{array}{l}\text { Proficiency in } \\
\text { English } \\
\mathrm{N}=183 \\
\mathrm{Pr}=0.209\end{array}$ & $\begin{array}{l}\text { Medium, Bad, Very bad } \\
\text { Very good and Good }\end{array}$ & $\begin{array}{l}20.83 \\
79.17\end{array}$ & $\begin{array}{l}20.93 \\
79.07\end{array}$ & $\begin{array}{l}9.09^{*} \\
90.91^{*}\end{array}$ & $\begin{array}{l}18.03 \\
81.97\end{array}$ \\
\hline \multicolumn{6}{|l|}{ Family background } \\
\hline $\begin{array}{l}\text { Mother's highest } \\
\text { education } \\
\mathrm{N}=183 \\
\mathrm{Pr}=0.533\end{array}$ & $\begin{array}{l}\text { less than university } \\
\text { education } \\
\text { university education }\end{array}$ & $\begin{array}{l}47.92 \\
52.08\end{array}$ & $\begin{array}{l}58.14 \\
41.86\end{array}$ & $\begin{array}{l}50.00 \\
50.00\end{array}$ & $\begin{array}{l}50.82 \\
49.18\end{array}$ \\
\hline $\begin{array}{l}\text { Father's highest } \\
\text { education } \\
\mathrm{N}=184 \\
\mathrm{Pr}=0.760\end{array}$ & $\begin{array}{l}\text { less than university } \\
\text { education } \\
\text { university education }\end{array}$ & $\begin{array}{l}25.77 \\
74.23\end{array}$ & $\begin{array}{l}30.95 \\
69.05\end{array}$ & $\begin{array}{l}24.44 \\
75.56\end{array}$ & $\begin{array}{l}26.63 \\
73.37\end{array}$ \\
\hline $\begin{array}{l}\text { Support of family } \\
\text { to move abroad } \\
N=183 \\
\operatorname{Pr}=0.612\end{array}$ & $\begin{array}{l}\text { encourages move } \\
\text { doesn't care/neutral } \\
\text { prefers stay }\end{array}$ & $\begin{array}{l}63.92 \\
7.22 \\
28.87\end{array}$ & $\begin{array}{l}75.61 \\
2.44 \\
21.95\end{array}$ & $\begin{array}{l}66.67 \\
8.89 \\
24.44\end{array}$ & $\begin{array}{l}67.21 \\
6.56 \\
26.23\end{array}$ \\
\hline $\begin{array}{l}\text { Average monthly } \\
\text { income of the } \\
\text { household } \\
N=181 \\
\operatorname{Pr}=0.539\end{array}$ & $\begin{array}{l}\text { Less than Rs. 25000/- } \\
\text { Between Rs. 25001/- } \\
\text { and 30,000/- } \\
\text { Between Rs. 30,001/- } \\
\text { and 40,000/- } \\
\text { More than Rs. 40,000/- }\end{array}$ & $\begin{array}{l}45.36 \\
15.46 \\
13.40 \\
25.77\end{array}$ & $\begin{array}{l}31.71 \\
29.27^{*} \\
14.63 \\
24.39\end{array}$ & $\begin{array}{l}41.86 \\
16.28 \\
18.60 \\
23.86\end{array}$ & $\begin{array}{l}41.44 \\
18.78 \\
14.92 \\
24.86\end{array}$ \\
\hline $\begin{array}{l}\text { Area of residence } \\
\mathrm{N}=185 \\
\mathrm{Pr}=0.257\end{array}$ & $\begin{array}{l}\text { Urban metropolitan } \\
\text { area } \\
\text { Semi-urban, smaller } \\
\text { cities and towns } \\
\text { Rural area }\end{array}$ & $\begin{array}{l}27.27 \\
56.57 \\
16.16\end{array}$ & $\begin{array}{l}23.81 \\
54.76 \\
21.43\end{array}$ & $\begin{array}{l}43.18^{* *} \\
40.91^{*} \\
15.91\end{array}$ & $\begin{array}{l}30.27 \\
52.43 \\
17.30\end{array}$ \\
\hline \multicolumn{6}{|l|}{ Migration history } \\
\hline $\begin{array}{c}\mathrm{N}=221 \\
\operatorname{Pr}=0.213\end{array}$ & $\begin{array}{l}\text { Respondent not lived } \\
\text { abroad } \\
\text { lived abroad }\end{array}$ & $\begin{array}{l}86.99 \\
13.01\end{array}$ & $\begin{array}{l}86.96 \\
13.04\end{array}$ & $\begin{array}{l}76.92^{*} \\
23.08^{*}\end{array}$ & $\begin{array}{l}84.62 \\
15.38\end{array}$ \\
\hline \multicolumn{6}{|l|}{ Network abroad } \\
\hline $\begin{array}{l}\text { Parents } \\
\mathrm{N}=167 \\
\mathrm{Pr}=0.403\end{array}$ & $\begin{array}{l}\text { Parents not lived abroad } \\
\text { lived abroad }\end{array}$ & $\begin{array}{l}93.26 \\
6.74\end{array}$ & $\begin{array}{l}86.11 \\
13.89\end{array}$ & $\begin{array}{l}92.86 \\
7.14\end{array}$ & $\begin{array}{l}91.62 \\
8.38\end{array}$ \\
\hline $\begin{array}{l}\text { Sibling* } \\
\mathrm{N}=167 \\
\operatorname{Pr}=0.078\end{array}$ & $\begin{array}{l}\text { Siblings not lived abroad } \\
\text { lived abroad }\end{array}$ & $\begin{array}{l}82.95 \\
17.05\end{array}$ & $\begin{array}{l}73.68^{*} \\
26.32^{*}\end{array}$ & $\begin{array}{l}92.68^{*} \\
7.32^{*}\end{array}$ & $\begin{array}{l}83.23 \\
16.77\end{array}$ \\
\hline $\begin{array}{l}\text { Extended family } \\
\mathrm{N}=167 \\
\operatorname{Pr}=0.950\end{array}$ & $\begin{array}{l}\text { Extended family not } \\
\text { lived abroad } \\
\text { lived abroad }\end{array}$ & $\begin{array}{l}57.95 \\
42.05\end{array}$ & $\begin{array}{l}55.26 \\
44.74\end{array}$ & $\begin{array}{l}58.54 \\
41.46\end{array}$ & $\begin{array}{l}57.49 \\
42.51\end{array}$ \\
\hline $\begin{array}{l}\text { Friends } \\
\mathrm{N}=169 \\
\operatorname{Pr}=0.142\end{array}$ & $\begin{array}{l}\text { Friends not lived abroad } \\
\text { lived abroad }\end{array}$ & $\begin{array}{l}45.56 \\
54.44\end{array}$ & $\begin{array}{l}43.59 \\
56.41\end{array}$ & $\begin{array}{l}27.50 * * \\
72.50 * *\end{array}$ & $\begin{array}{l}40.83 \\
59.17\end{array}$ \\
\hline $\begin{array}{l}\text { Colleagues*** } \\
\mathrm{N}=165 \\
\mathrm{Pr}=0.002\end{array}$ & $\begin{array}{l}\text { Colleagues not lived } \\
\text { abroad } \\
\text { lived abroad }\end{array}$ & $\begin{array}{l}54.02^{*} \\
45.98^{*}\end{array}$ & $\begin{array}{l}59.46 \\
40.54\end{array}$ & $\begin{array}{l}24.39^{* * *} \\
75.61^{* * *}\end{array}$ & $\begin{array}{l}47.88 \\
52.12\end{array}$ \\
\hline
\end{tabular}

Note: Pearson's Chi-square test; Significance levels * $p<0.1,{ }^{* *} p<0.05, * * * p<0.01$ 
A general observation can be made that students' personal profiles do not differ much between those that choose one destination or another. Only in terms of having children, level of studies and having networks abroad, we observe differences in country choice that are statistically significant. Relationship between having children and the choice of a country is statistically significant at a $99 \%$ confidence level. As it turns out, the number of cases of students with children wanting to go to any of the other Anglo-Saxon countries is significantly smaller than would be expected. At the same time, students who have children are significantly more likely to choose any of the European destinations. When looking at division by students' community belonging, we observe that among those that would choose the United States, there are relatively more Hindus than in the other two destination groups. Refraining from drawing general explanations for migration aspirations for such a heterogeneous group, we can still attempt to explain the different geographical focus by the probable mechanism of path dependency of earlier migration. In the past decades, the United States has been the main destination for highly-skilled Indians and has now an established Indian community which consists primarily of Hindus. While Hindus are the dominant emigrant group within each destination region, the United States stands out with the highest relative percentage of Hindu migrants compared to other regions of immigration, with the Middle East having the lowest relative percentage; 82.7 percent and 49.7 percent, respectively. For comparison, Hindus represent 79.7 percent of Indian migrants in the United Kingdom and 67.8 in Europe other than the United Kingdom (Kapur, 2010). As the network effect pulls future flows towards the existing migrant population of their own community, this could explain relative preference of Hindus to follow in the footsteps of other Hindus. In this manner, earlier migration determines the difference in preferences between communities for the future generations. As for the non-Hindu population, we observe the lowest relative percentages of Muslim as well as Christian emigrants in the United States (10 percent and 3.8 percent of all Indian immigrants in the country, respectively) as compared to the other countries and regions. Since the networks of previous migrants from their own community are scarce, they are missing the positive effects which could be available in a form of providing relevant information and facilitating access to universities and future employment. Nevertheless, it is important to mention that in our sample despite the relatively smaller share of nonHindu respondents among those that prefer the United States, many of them still put it as the first choice for migration (41.3 percent) (Table 7.4). 
Table 7.4: Distribution of responses by community across countries and regions

\begin{tabular}{l|lll|l}
\hline & United States & Anglo-Saxon & Europe (other than UK) & Total \\
\hline non-Hindu & 19 & 14 & 13 & \\
$\%$ & 41.3 & 30.43 & 28.26 & 46 \\
Hindu & 73 & 25 & 29 & 100 \\
$\%$ & 57.48 & 19.69 & 22.83 & 127 \\
\hline Total & 92 & 39 & 42 & 100 \\
$\%$ & 53.18 & 22.54 & 24.28 & 173 \\
\hline
\end{tabular}

In terms of the university background, we observe that students in different levels of their study programmes differ in terms of a chosen destination country with a statistical significance of 5 percent. Among those students who pick European countries, there is a higher than average representation of students in their Bachelor programmes. The Anglo-Saxon countries seem to attract more Masters Students, who are highly represented within this group; nevertheless, respondents pursuing PhD studies or post-doctoral studies have a low representation among those who picked any of four Anglo-Saxon countries. Looking closer into the differences in terms of country choice, we observe that continental European countries have higher attraction for people in natural sciences (as opposed to engineering fields). Among those students who pick European countries 49 percent are pursuing studies in natural sciences, while among those who want to go to the United States the share of natural science students is only 36.7 percent. In terms of students' performance, we observe only minor differences between the chosen countries. Proficiency in English displays unexpected outcomes. Among the ones that want to move to Europe, only 9 percent of students report their knowledge of English as medium or worse level ${ }^{74}$. The share of students with worse command of English rises for students with the English-speaking countries as a preferred country to just over 20 percent. That there is a higher proportion of respondents with good knowledge of English for the continental European countries is difficult to explain with the results of this study. One possible explanation could be that the knowledge of English language is a necessary condition for anyone to look for information on possibilities for migration. As accessing information in the non-English-speaking countries requires more skills, this might mean that only those who are more versatile are able to overcome the language obstacles.

In terms of students' family background, none of the observed dimensions prove to display statistically significant differences with respect to choosing a certain country. With respect to parents' education, we observe that students who choose any of the four Anglo-Saxon countries tend to have parents with lower educational

${ }^{74}$ The difference with the averages from the other chosen destinations is significant at $10 \%$ level. 
level compared to those that would choose continental Europe or the United States; however the differences are statistically insignificant. Looking at the area of families' residence, the students with preference for Europe are more likely to come from urban metropolitan areas.

We observe that among students who have a preference for continental European countries a significantly higher percentage has lived abroad in the past as compared to students preferring other destinations. 23 percent of those that would choose Europe as a destination region have already had some experiences with living abroad while only 13 percent of those that would go to English-speaking countries have had such experience. In a similar way, it is those respondents who have a preference for Europe that are more likely to have friends and colleagues living abroad. One interview respondent clearly stated that a university in Sweden was his first priority as he had been there as an exchange student earlier and he knew the group of people he would work with. Another student from JNU reasoned his decision to apply to a Max Planck institute in Germany because he knows several students from his Bachelors programme in India who had been accepted earlier and therefore expects the chance for him to be similar. At the same time, some other students spoke of lack of information for going to Europe. Abijey, a Master student in aerospace engineering at the IISC Bangalore, explains his problems with finding information for post-graduate programmes in Germany:

Say, for us aerospace people, Germany is a very good place to go... But they are not very clear about their procedures and how to apply there and things like that. Which are in the case of US known. You know specific ways to do things from other friends who are already there. And we also heard, socially we will get some friends from India. We'll get someone who is from your country and that's an advantage. But in Europe, say in Germany, we don't have any seniors over there... Most of the things we don't know, how to plan and all.

Judging from this result, we can conjecture that social ties are more important for planning to go to new destination countries as opposed to going to dominant destinations where the majority of migrants had gone. As Epstein (2008) explains, most new migrants will follow previous migrants assuming that they had access to convincing information to select that particular place. As a potential migrant with limited information about differences between different host countries, it is a conscious safer decision to follow previous migrants on the assumption that if so many people favoured that location they could not be wrong. Through such informational cascade or herd behavior, migrants group in the dominant destinations, causing that migration to other destinations stays limited (De Haas, 2010). To put it differently, those respondents who want to go to the traditional 
migration countries do not need a personal contact who would facilitate and aspire their migration: instead, they follow a general trend of earlier migrants. On the contrary, a plan to go to new destination countries is more dependent on the information received from people who are either based there at the moment or have earlier lived there. Even though network externalities are small considering the small population of earlier immigrants in the foreign location, migrants still decide to follow previous migrants basing their decision on experiences of others. In addition, in the more pioneering stages of migration to a particular destination, the feeling of solidarity and responsibility towards people coming from the same place is stronger, meaning that new migrants can count on more attention from the network.

In this section we demonstrated that students choosing certain locations differ in their personal and educational background. Respondents preferring European destinations are more likely to be male, from a reserved background, more of them have children. More of them also study natural sciences, are currently enrolled in Bachelor programmes, have a better command of English, are from urban area and have friends or colleagues who have lived abroad. These results point to a thoughtprovoking finding that more resources and skills are necessary for choosing a nontraditional destination country; be in either in terms of existing networks, higher education level or better language skills. Path dependency of earlier migration trajectories explains that most new migrants follow previous migrants to the same destination countries and only those who feel able to overcome the barriers and constraints associated with migration would choose not the most straight-forward location choice. An explanation for students from a reserved background preferring European destinations could lie in the scarcity of previous networks from their own community in the common destinations; however, an exhaustive study of the role of disadvantaged identities in driving migration decision-making in the Indian context remains to be researched in future work.

As previously pointed out, this study includes any plans for international mobility, either for the purpose of education, for work or for another reason. Although students' migration decisions involve similar incentives as for labour migrants, the institutional context of their decision is different (Kahanec \& Zimmermann, 2011). We observe if differences in migration planning project vary by the preferred destination and find a statistically significant correlation at 95 percent confidence level (see Table 7.5). The number of respondents planning to go to the Anglo-Saxon countries for work-related reasons is significantly larger than expected. Quite the reverse, this number is smaller than expected for European destinations. This indicates that European destinations are attractive for studying but much less for labour migration. Also when we observe the correlation between desired duration 
of stay abroad and the destination preference, we see that the share of those who plan to stay abroad for more than 5 years is lower among students with any of the continental European countries as the first choice. As such, the European countries are rarely seen as a place for potential long-term stay abroad and, when chosen, it is mainly just for the period of studying.

Table 7.5: Destination preference and reason for going abroad (in percentages)

\begin{tabular}{l|lllll}
\hline & & USA & $\begin{array}{l}\text { Anglo-Saxon } \\
\text { countries }\end{array}$ & $\begin{array}{l}\text { European } \\
\text { countries }\end{array}$ & Total \\
\hline $\begin{array}{l}\text { Reason for } \\
\text { going }\end{array}$ & $\begin{array}{l}\text { Studying, } \\
\text { education }\end{array}$ & 69.47 & $54.35^{* *}$ & 74.55 & 67.67 \\
$\begin{array}{l}\mathrm{N}=232 \\
\mathrm{Pr}=0.030\end{array}$ & Work & 26.72 & $39.13^{* *}$ & $14.55^{* *}$ & 26.29 \\
\hline
\end{tabular}

Pearson's Chi-square test; Significance levels ${ }^{*} p<0.1,{ }^{* *} p<0.05,{ }^{* * *} p<0.01$

In the following section we present a comparison of students preferring certain locations and their consideration for importance of factors in a certain place.

\subsubsection{Evaluation of the factors}

The students were asked to rank on a five-point scale the importance for a number of stated factors for the country where they want to live. Again we divide the responses by their preference for the destination country/region in three columns, plus an additional column for mean values of all respondents. Table 7.6 provides the mean values of all factors for each of the three studied destination regions. The numbers given as the upper case designate the ranking of the five most important factors within a certain destination region. On the whole, it can be observed that students who want to go to the United States value the majority of factors higher compared to students from the other two observed destinations. In addition, respondents put high ranks across the factors, with none of the factors ranked on average below the neutral value of three. The most important factors for all students are related to career path. The students who have picked the United States as their preferred country choice place on average the highest value on quality and content of their work, good research facilities and recognition for qualifications. Also for the students preferring other Anglo-Saxon countries, quality of work is regarded as most important. For continental European countries, in contrast, this factor came only as the eleventh most important in mean values. The most important for respondents with preferences for continental European countries is good quality of higher education institutions, followed by quality of research facilities, which clearly shows their focus on moving abroad for the 
purpose of studying. A student from JNU who picked Sweden for his post-doctoral programme explains in the interview:

Basically I chose to go to Stockholm University because they are famous for the Nobel laureate and the research council. And there is already collaboration between my professor and Stockholm University. So first I go and see which group is going to publicize more papers in the future and which group has been handed the best project in this work.

His reasoning of placing the highest value on the quality of research facilities is typical for several other interviewees following an academic career. However, noneducational factors figure rather prominently in the location deliberations. A PhD in Environmental Engineering from JNU explains her thinking about the role of country image in her moving plans:

Maybe we have a lot of work going on in Taiwan or in China but maybe because of the kind of lifestyle we would have over there, we would prefer to go somewhere better. Or maybe we will not go to very small places. We are not very sure of what kind of life it would be. Or maybe if we would be offered to go to Kenya or something like that, we would think twice. So I do think it will matter in the long run.

Interestingly, student preferring Anglo-Saxon countries place high importance on safety factors. They placed public safety as well as political stability among the first five most important factors. This aspect is worth further exploration as, during the in-depth interviews, concerns over safety were expressed especially with respect to the attacks on Indian students in Australia and experiences with discrimination in the United Kingdom. This could explain why for those students who plan to move to Anglo-Saxon countries are more concerned about the safety and hence rank them as relatively more important.

Given that students who prefer the United States in general rank factors with greater importance, it is difficult to compare the mean values across countries/regions. The biggest differences in mean values between the group preferring the United States and the group preferring the European countries appears at the factor of quality and content of work, the need to learn a new language and in the value given to possibility of not working more than 8-hour per day. In the interview, Parveen, a PhD student in environmental engineering, JNU, explains that he heard from other people who were in Europe that they experienced less work pressure, which helps him pick a location suitable for his wishes:

In my experience I don't want to work so much. So I would like to do the routine works like the 9 to 5 hours in a week. Next to my research I also want 
to give time to my personal things. That is why I choose Europe rather than going to the USA. And even I would like to go more to the Scandinavian countries than to go to Germany or France. Because in Germany the work pressure is very high.

We can observe that students who prefer European countries place higher mean value in comparison with those preferring the United States only in three cases. These are the following: rich cultural institutions, social security and benefits and friendly hospitable population. However, none of these criteria is regarded very important in comparison to other factors. Considering that students preferring Europe ranked these factors relatively low in terms of importance, means they do not have much value in terms of attractiveness.

In sum, it can be said that perceptions about the situation in potential countries favours the United States (mentioned in one interview as "top country"), which indicates an image problem faced by the other potential destination. The governments are putting considerable efforts to expand a market for higher education in Asia with international recruitment industry and integration of student migration as a part of the wider immigration strategy. Most important factors for the decision to move to a foreign place appear to mainly relate to career path, either for education or work purposes. On average, factors related to social contacts and public policy rank lower in terms of importance, which is consistent with the study conducted on IT-graduates in India by Mahmood and Schömann (2003a). In their study, salary was shown to rank as the most important determinant with the highest mean values for all foreign countries except for the ones which want to stay in India. Likewise, mean values were the highest for all observed determinants by students preferring the United States.

Table 7.6: Comparison of mean values for factors by country and region alternatives

\begin{tabular}{|c|c|c|c|c|}
\hline & USA & $\begin{array}{l}\text { Anglo- } \\
\text { Saxon }\end{array}$ & European & Total \\
\hline high demand for my qualifications & 4.432 & 4.372 & 4.222 & 4.366 \\
\hline easily finding a suitable job after my studies & 4.168 & 4.093 & 4.089 & 4.131 \\
\hline attractive salary & 4.365 & 4.214 & 4.067 & 4.257 \\
\hline quality and content of my work & $4.75^{1}$ & $4.581^{1}$ & 4.289 & $4.598^{1}$ \\
\hline $\begin{array}{l}\text { good research facilities in companies and } \\
\text { public institutions }\end{array}$ & $4.691^{2}$ & $4.442^{3}$ & $4.511^{2}$ & $4.589^{2}$ \\
\hline no more than 8-hour working days & 3.674 & 3.571 & 3.356 & 3.571 \\
\hline career progression opportunities & $4.521^{5}$ & 4.286 & $4.4^{3}$ & $4.437^{5}$ \\
\hline $\begin{array}{l}\text { recognition of educational/professional } \\
\text { qualifications }\end{array}$ & $4.684^{3}$ & 4.317 & $4.364^{5}$ & $4.522^{4}$ \\
\hline $\begin{array}{l}\text { job security (not easy for employers to fire } \\
\text { workers) }\end{array}$ & 4 & 4.000 & 3.909 & 3.978 \\
\hline
\end{tabular}




\begin{tabular}{l|llll}
\hline costs of living & 4.084 & 3.929 & 3.954 & 4.017 \\
family-friendly environment & 4.032 & $4.419^{4}$ & 3.977 & 4.11 \\
$\begin{array}{l}\text { good quality of higher education institutions } \\
\text { multicultural environment }\end{array}$ & $4.629^{4}$ & 4.372 & $4.533^{1}$ & $4.546^{3}$ \\
$\begin{array}{l}\text { rich cultural institutions (museum, theatre, } \\
\text { cinema...) }\end{array}$ & 4.011 & 3.927 & 3.909 & 3.967 \\
$\begin{array}{l}\text { public safety } \\
\text { political stability, stable government }\end{array}$ & 4.263 & 4.791 & 3.791 & 3.691 \\
& 4.326 & $4.381^{1}$ & 4.256 & 4.337 \\
$\begin{array}{l}\text { economic stability } \\
\text { social equality among population }\end{array}$ & 4.326 & 4.381 & 4.318 & 4.337 \\
friendly, hospitable population & 4.372 & 4.070 & 4.349 & 4.337 \\
not feeling discriminated & 4.302 & 4.209 & 4.341 & 4.29 \\
$\begin{array}{l}\text { English commonly spoken } \\
\text { no need to learn a new language }\end{array}$ & 4.427 & 4.209 & 4.295 & 4.344 \\
having high social status & 4.206 & 4.163 & 4.023 & 4.152 \\
$\begin{array}{l}\text { attractive taxation system } \\
\text { quality and access to medical services } \\
\text { (hospitals, family doctor) }\end{array}$ & 3.646 & 3.535 & 3.204 & 3.514 \\
$\begin{array}{l}\text { social security and benefits (such as } \\
\text { unemployment benefits, pensions) }\end{array}$ & 3.842 & 3.659 & 3.651 & 3.754 \\
\hline
\end{tabular}

Note: The numbers in the upper case show ranking of the five most important factors within a certain destination region.

While the previous question was asked to all respondents referring to the place where they want to live, the subsequent questions address only the evaluation of factors if they had plans to move abroad. Firstly, we asked how important it is for them to live near a large Indian community in a prospective host country. Although increasing, there are still relatively small numbers of migrants from India in continental European countries, so it is according to expectations that migrant networks are not that much relevant to those who prefer moving to Europe over other destinations. Aseem, a Bachelor student in chemical engineering at BHU-IT, talked about the difficulties he would expect from living in a place with a small Indian community:

...if we go to some place where there aren't very many Indians there...Like in a place in Europe, I don't think there are many Indians compared to America. (...) So, if you don't find the people to whom you relate, how can you relate to yourself? So, there will be problem for you and you can adjust in the US much easier. (...) I prefer where there are peoples which I can relate to, I can enjoy, and we can have gatherings and we can have common thing that we can 
share with each other. Because I can adjust; anyone can adjust to other place where you can relate to yourself.

In the reminder of the question, students were asked to rank the importance of policy-related factors. In comparison to other factors, migrant networks play a less important role than admission procedures. It is notable to observe that in terms of immigration policies, the possibility of permanent settlement and acquisition of citizenships rank the lowest. Especially for students who choose Europe as a destination area, the possibility of settlement is particularly not important. The students are much more interested in clear application procedures and the chance that immigration policies will allow them to re-enter the country later on in the career.

Table 7.7: Comparison of mean values for factors relevant for immigration policy by country and region alternatives

\begin{tabular}{l|lll|l}
\hline & USA & $\begin{array}{l}\text { Anglo- } \\
\text { Saxon }\end{array}$ & $\begin{array}{l}\text { European } \\
\text { countries }\end{array}$ & Total \\
\hline Living near a large Indian community & $3.65^{5}$ & $3.381^{6}$ & $3.070^{6}$ & $3.454^{5}$ \\
Easily bringing in my family now or later & $3.814^{3}$ & $3.571^{4}$ & $3.302^{4}$ & $3.642^{4}$ \\
I can easily return to later in my career & $4.21^{2}$ & $3.900^{1}$ & $3.977^{2}$ & $4.086^{2}$ \\
Clear application procedure for residence and & $4.24^{1}$ & $3.875^{2}$ & $4.114^{1}$ & $4.13^{1}$ \\
work permit & & & & \\
Accessibility of your spouse to the labour market & $3.586^{6}$ & $3.385^{5}$ & $3.186^{5}$ & $3.448^{6}$ \\
Being able to stay in a country longer than 5 years & $3.72^{4}$ & $3.775^{3}$ & $3.429^{3}$ & $3.665^{3}$ \\
Possibility of permanent settlement & $3.243^{8}$ & $3.073^{8}$ & $2.837^{8}$ & $3.112^{8}$ \\
Possibility of acquiring local citizenship & $3.301^{7}$ & $3.100^{7}$ & $3.093^{7}$ & $3.21^{7}$ \\
\hline
\end{tabular}

Note: The numbers given as the upper case designate the ranking of the most important factors within a certain destination region.

We have so far demonstrated that there are characteristic differences between people with respect to location choice, as well as at point different ratings of factors relevant for potential host country. To identify which of these factors increase the likelihood that respondents express plans to go to a specific location, we will use a multinomial logit regression analysis in the next section.

\subsubsection{Multinomial logit regression}

We use a multinomial logit specification to model the choice between three prospective destinations: a) The United States, b) The Anglo-Saxon countries (The United Kingdom, Canada, Australia and New Zealand) and c) continental European countries. Multinomial logit models are used to model relationships between a polytomous response variable and a set of regressor variables (Kuhfeld \& So, 2007). 
This specification allows us to test whether the factors associated with preferring one destination are statistically different from the factors associated with preferring another destination. The Multinomial Logit Model (MNLM) is based on the principle that individuals choose the outcomes which maximise the utility derived from their choice. A rational person would choose an alternative that maximizes the utility derived from the choice. An individual $i(i=1, \ldots, N)$ faces $m$ possible choices, with $\mathrm{Y}_{\mathrm{ij}}{ }^{*}$ denoting the level of indirect utility associated with the jth choice, called the latent variable. The observed variables $Y_{i j}$ are defined as:

$Y_{i j}=1 \quad$ if $Y_{i j}{ }^{*}=\operatorname{Max}\left(Y_{1}{ }^{*}, Y_{2}{ }^{*}, \ldots, Y_{m}{ }^{*}\right)$

$Y_{i j}=0 \quad$ Otherwise

If $Y_{i j}{ }^{*}=V_{j}\left(X_{j}\right)+\varepsilon_{j}$ where $X_{j}$ is the vector of attributes for the jth choice and $\varepsilon_{j}$ is the random error associated with that choice, the specific form of the model is determined by the assumed distribution of $\varepsilon$ and the specification of how $\mathrm{V}_{\mathrm{j}}\left(\mathrm{X}_{\mathrm{j}}\right)$ is related to the measured variables (Constant \& D'Agosto, 2008).

We study the migration intentions of Indian students prior to their move. The dependent variable is a categorical variable of three unordered outcomes. In estimating the model, the continental European countries are chosen as the reference outcome to which we compare the remaining two alternative destinations. ${ }^{75}$ The explanatory variables should explain the impact of demographic factors, university background as well as the value placed on economic, sociopolitical and institutional factors on country choices. On the basis of the earlier empirical studies as well as based on the observations form the descriptive statistics, we select a group of variables which could explain the country choice of individual students. Table 7.8 reports the results of the multinomial logit model with the reference category of having intentions to move to continental European countries. We focus on the results which are statistically significant.

The results show that people in relationships are less likely to choose the United States (as opposed to European countries) than single people. In fact, the marginal effects show that they are 39 percent less likely to plan the move to the United States than single people, compared to the option of going to European countries. Also the field of studies turns out to be a significant determinant for location choice. Those who study engineering are more likely to go to the United States compared to students in natural sciences. The results clearly show that country choice can be well explained by the level of educational programme. Compared to students enrolled in Bachelor programmes, both, Master students as well as PhD student

\footnotetext{
${ }^{75}$ A small number of students who expressed the intention of going to countries other than those belonging to the three studied groups are omitted from the analysis.
} 
and Post-Doctoral researchers are more likely to plan the move to the United States. This result is in particular strong for PhD students and Post-Doctoral researchers, who are 72 percent more likely to go to United States than to Europe.

Considering that descriptive statistics show no statistically significant differences for choosing a certain country in terms of students' family background, we decided not to include these variables in the model. That parents' encouragement is an important factor for migration decision has been demonstrated in Chapter 6 . With the results from the location choice analysis we further show that parents' support is more important for going to Europe. For both alternative destinations, students perceive their parents' attitude towards their move abroad as less encouraging than students planning to go to Europe. In addition to having parents' support, the networks of people living abroad can also explain country preferences. As migration network theory focuses on the prediction of new migration flows based on the settlement of migrants in specific places of destination (Stark \& Wang, 2002), we find that having friends who live abroad plays a significant role for choosing the continental European countries versus the United States. In the same way as for the decision to move abroad or not (Chapter 6), our results show that so called "weak ties" in contacts with friends and colleagues matter more than "strong ties" also in terms of country choice exercise, congruent with Granovetter's hypothesis on the "strength of weak ties" (Granovetter, 1973). While including family networks as well as non-kinship networks in the model, only having friends living abroad is a significant determinant for choosing European countries over the United States. Migration to the United States and to other Anglo-Saxon countries appears not to require first-hand information from personal contacts as there is abundant information available from previous migration emerging into a migration system (discussed further below) (Mabogunje, 1970). Information about migrants' success and reception in receiving countries is conveyed back to the origin through news as well as through other widely available feedback mechanisms, which reduces unobserved conditions in receiving countries (Radu, 2008). In this case existing migrant network is not required, as most migrants will move where the others have gone earlier, leading to self-reinforced migration behaviour (Epstein, 2008). For new destinations, however, networks are important for sharing information and increasing awareness and aspirations for considering that specific place. Therefore, students who would pick any of the European countries use their friends abroad as "bridgeheads" (Böcker, 1994) by depending on their bridging capital to provide information on existing options. It is the access to information which makes migration to new destinations more likely for groups with strong bridging capital (De Haas, 2010). Still, minor Indian communities in continental European countries play against choosing any of them as a potential destination for those students who rank the closeness of Indian community at a high value. Students with preference 
to live close to the existing Indian community exhibit a clear, statistically significant, preference for the United States. A Master student in physics from JNU speaks in favour of choosing the United States for the reason of being able to benefit from the safety network of their relatives:

A lot of Indians settle in the US. So my relatives are also there. So if there's a good university in a place where my relatives are, then probably I would prefer going to that place because at least I know somebody there. There would be a moral support and you know, once in a while you have a change, where you go to your place and your people. That would actually give you... That will give you a moral support.

Considering the high concentration of highly-skilled Indians in the United States (66.4 percent of all highly-educated Indians living abroad (OECD.stat)), it is evident that current Indian migrants follow in the footsteps of the recent wave of skilled migration starting from the 1970s onwards. The four decades long history of ever increasing waves of highly-skilled migration between India and the United States resulted in "geographical structuring and clustering of migration flows" (Bakewell, de Haas, \& Kubal, 2011, p. 5), making the United States close to synonymous with the decision of going abroad.

From the question on importance of factors for respondents' consideration on the location choice we included those factors which were found to be relatively more important by the respondents and where we found larger differences between students preferring different destinations (Section 7.3.2). Looking at other subjective ratings of importance in our results, the country choice decision is influenced by importance placed on the quality of educational institutions. Students who consider high-level educational institutions very important for the place where they would like to locate themselves are less likely to pick the AngloSaxon countries. This is consistent with the finding that migration to other AngloSaxon countries is more likely to be motivated by work-related reasons. In comparison, it is evident that students choosing the continental European countries value educational factors very highly, indicating that continental Europe is primarily a destination for studying and to a lower extent thought of as a location for a longer stretch of time.

The local characteristics, also referred to as amenities, affect the quality of life because people have preferences for certain types of areas, for example areas that offer more security, better access to facilities, more moderate climate, and the like. Mori (Price et al., 2003) recognizes location and social facilities in a city as an important environmental condition that influences students' choice. However, our results show that the importance placed on amenities of local environment does not vary significantly between Indian students choosing different locations. The 
feeling of safety, importance of living in a family-friendly environment and being in a different language environment do not determine preferences for locations.

In order to observe the effect of immigration policies in migration decisions, we include the respondents' rating of how important application procedures are for their prospective host country. Our results show that such rating is a significant determinant for the choice of going to the United States as opposed to migrating to continental European countries. The marginal effects show that students who place the importance of clear application procedures for residence and work permits at a high value are 14 percent more likely to choose the United States. Again, this shows the motivation to continental European countries to be limited for the purpose of higher education, reducing the relevance students place on admission procedures. Considering that admission procedures are less demanding for international students, those respondents who are exclusively interested in going abroad for studying are found to place less importance on immigration procedures, as has been often explicitly mentioned in several in-depth interviews. The commonly mentioned perception regarding immigration procedures is that the US is far more lenient than European countries when it comes to immigration option. Aseem, from BHU-IT, gives one such opinion:

Some of the European countries, like France and Germany, they're quite harsh because of their leaders there; they're having some problem there, so what they think, if Indians or any other people get into the country, then they will eventually cause less opportunities for the people of their country...

Moreover, students' mobility plans to go to the United States apparently already involve incentives to stay abroad also after the completion of studies, when obtaining a residence and work permit becomes a necessary step to take into consideration.

Table 7.8: Country choice coefficient estimation results

\begin{tabular}{l|llll}
\hline Independent variables & \multicolumn{2}{l}{$\begin{array}{l}\text { Probability for choosing } \\
\text { the US }\end{array}$} & \multicolumn{2}{l}{$\begin{array}{l}\text { Probability for choosing } \\
\text { the other Anglo-Saxon } \\
\text { countries }\end{array}$} \\
\hline $\begin{array}{l}\text { (reference: education-motivated } \\
\text { move) }\end{array}$ & $\begin{array}{l}\text { Coefficient } \\
\begin{array}{l}\text { Work-related move } \\
\text { Other reasons to move }\end{array}\end{array}$ & $\begin{array}{l}\text { St. Error } \\
0.647\end{array}$ & $\begin{array}{l}\text { Coefficient } \\
1.827^{* *}\end{array}$ & $\begin{array}{l}\text { St. Error } \\
0.871\end{array}$ \\
$\begin{array}{l}\text { Female } \\
\text { (reference: from a Hindu community) }\end{array}$ & -1.052 & 1.785 & -1.443 & 2.890 \\
$\begin{array}{l}\text { from a non-Hindu community } \\
\text { (reference: single as a reference) } \\
\text { in a relationship/married }\end{array}$ & 0.979 & 1.245 & 1.259 & 1.461 \\
has children & $-1.817^{* *}$ & 0.861 & -0.233 & 1.518 \\
\hline
\end{tabular}




\begin{tabular}{|c|c|c|c|c|}
\hline $\begin{array}{l}\text { (reference: research-oriented } \\
\text { universities) } \\
\text { Practical/applied universities }\end{array}$ & 2.999 & 2.506 & -0.687 & 3.027 \\
\hline $\begin{array}{l}\text { (reference: studies engineering) } \\
\text { studies natural sciences }\end{array}$ & $-1.863 * *$ & 0.837 & 0.010 & 1.163 \\
\hline $\begin{array}{l}\text { (reference: enrolled in Bachelors } \\
\text { programme) } \\
\text { enrolled in Masters programme } \\
\text { doing a PhD or Post-Doc }\end{array}$ & $4.550 * *$ & 1.974 & 2.152 & 2.031 \\
\hline $\begin{array}{l}\text { (reference: parents prefer stay) } \\
\text { parents encourage move } \\
\text { parents neutral to move }\end{array}$ & $\begin{array}{l}-1.769 * * \\
-1.532\end{array}$ & $\begin{array}{l}0.840 \\
1.328\end{array}$ & $\begin{array}{l}-0.770 \\
-17.513^{* * *}\end{array}$ & $\begin{array}{l}1.258 \\
3.957\end{array}$ \\
\hline $\begin{array}{l}\text { (reference: below average household } \\
\text { income) } \\
\text { above average household income }\end{array}$ & -0.060 & 1.053 & 0.127 & 1.498 \\
\hline $\begin{array}{l}\text { (reference: from an urban area) } \\
\text { from a semi-urban area } \\
\text { from a rural area }\end{array}$ & $\begin{array}{l}-0.541 \\
1.212\end{array}$ & $\begin{array}{l}0.625 \\
1.133\end{array}$ & $\begin{array}{l}0.770 \\
2.074\end{array}$ & $\begin{array}{l}1.351 \\
1.939\end{array}$ \\
\hline $\begin{array}{l}\text { (reference: respondent never lived } \\
\text { outside India) } \\
\text { lived outside India in the past }\end{array}$ & 1.609 & 1.026 & -0.173 & 1.109 \\
\hline parents have lived abroad & -1.691 & 2.154 & 2.032 & 2.175 \\
\hline siblings have lived abroad & 2.596 & 1.894 & 1.614 & 2.202 \\
\hline friends lived abroad & $-1.239 *$ & 0.694 & -0.603 & 0.921 \\
\hline colleagues lived abroad & -1.074 & 0.896 & -1.089 & 1.243 \\
\hline $\begin{array}{l}\text { importance of quality and content of } \\
\text { work }\end{array}$ & 0.665 & 0.688 & -0.252 & 0.586 \\
\hline $\begin{array}{l}\text { importance of good quality of } \\
\text { education institutions }\end{array}$ & -0.108 & 0.810 & $-1.906^{*}$ & 1.128 \\
\hline $\begin{array}{l}\text { importance of family-friendly } \\
\text { environment }\end{array}$ & 0.752 & 0.488 & 0.801 & 0.530 \\
\hline importance of public safety & -0.765 & 0.561 & 0.822 & 0.895 \\
\hline $\begin{array}{l}\text { importance of not having to learn a } \\
\text { new language }\end{array}$ & 0.314 & 0.313 & 0.115 & 0.323 \\
\hline $\begin{array}{l}\text { importance of being close to an } \\
\text { Indian community }\end{array}$ & $0.679 * *$ & 0.320 & 0.226 & 0.482 \\
\hline Importance of application procedures & $0.714 *$ & 0.399 & -0.109 & 0.560 \\
\hline Log likelihood & -65.407 & & -65.407 & \\
\hline Pseudo $R^{2}$ & 0.4214 & & 0.4214 & \\
\hline Number of observations & 112 & & 112 & \\
\hline
\end{tabular}

Notes: Comparison outcome is the probability to migrate to continental European countries. Significance levels ${ }^{*} p<0.1,{ }^{* *} p<0.05,{ }^{* * *} p<0.01$; robust standard errors in the second column.

\subsection{Conclusion}

The main objective of this chapter is to observe if the determinants of migration to continental Europe are different from determinants of migration to the AngloSaxon countries (UK, Canada and Australia) or to the United States. Despite the 
increasingly common alarms that the United States is losing its triumphant position of attracting the best and the brightest from all over the world (Wadhwa, 2012), our results show quite the contrary. In our sample of Indian science and engineering students, a remarkable 52.7 percent choose the United States as their first option for moving abroad. The second most often mentioned country, Germany, is lagging far behind at 13 percent of the answers. Nevertheless, it is of relevance for assessing the attraction of European countries to find Germany stated more often than the United Kingdom, Canada or Australia and also, to find Switzerland, The Netherlands and France being mentioned by more respondents as their first choice.

We find that students choosing European countries differ in several aspects from those choosing the United States. As in earlier studies (Constant \& D'Agosto, 2008; De Grip et al., 2009), specialization of Indians in certain field of studies is a strong predictor of country preference. Indian students in engineering have stronger tendency to move to the United States, while continental European countries have higher attraction for students in natural sciences. Students in advanced research programmes are especially interested in moving to the United States. The results also show that students who plan to go to Europe more often have friends or colleagues living abroad, have better command of English and are from urban areas, which leads us to conclude that moving to Europe requires more resources and skills. Migration to new destinations often entails higher costs and risks (De Haas, 2010, p. 12), which can be overcome by existing networks, higher income levels and better language skills. These enable potential movers to overcome the lack of information about new destinations and persevere on moving to less common destinations. Four decades of highly-skilled migration from India to the United States emerged into a migration system, where:

"formal and informal subsystems operate to perpetuate and reinforce the systematic nature of international flows by encouraging migration along certain pathways, and discouraging it along others" (Mabogunje, 1970, $p$. 12).

The movements of large flows of skilled Indians to the United States is linked also with large flows of good, capital, ideas, and information (Fawcett, 1989), which leads to "an identifiable geographical structure that persists across space and time" (Mabogunje, 1970, p. 12). Most migrants follow informational cascade and herd behaviour trusting the decisions of preceding migrants, which leads to difficulties in new destinations, such as continental European countries, to attract foreign talent. There is a growing agreement that skilled migration is desirable for Europe (Kahanec \& Zimmermann, 2011), which lead to adjustments of migration policies as well as internationalization of education programmes in order to attract foreign students as an important source of highly-skilled migrants (Boeri et al., 2012). Our 
finding show that European countries are relatively attractive destinations for Indian students for study purposes but have a problem in retaining foreign students after their studies. They are obviously not perceived as a place with good career opportunities for a probable long-term stay. Few students planning to go to continental Europe plan to stay longer than five years, the possibility of settlement or obtaining a citizenship is rated as unimportant for their move abroad and their decision to pick Europe can be explained by rating quality of educational institutions with high importance. All these findings point to the problem that continental European countries face for retaining foreign students. Soutar and Turner (2002), Binsard and Ekwulugo (2003) are among the papers which have through empirical studies proven the relevance of job prospects in the decision making process of students. Finding in our dataset that students who chose the United States or the other Anglo-Saxon countries place the highest value on quality and content of their work, while for continental European countries this factor was on average rated only as the eleventh most important, shows again that European countries have to change the perception of and the actual career possibilities in order to be regarded as attractive career destinations.

We find that information available to students about potential destinations is limited, making the decision dependent on the available information and existing perceptions about which options are best for them. The decision is based on a limited number of better known choices, picking their preferred destination out of a few options. Adjustment of migration policies in Europe which enables students to stay in destination countries after completion of their studies has not apparently activated the desired response to make given locations more attractive for work migration. The competition for the best and the brightest of the world is tough and is a relevant policy concern of many governments. Europe may continue to be the "land of missed opportunity, unable to attract the talent" (Boeri et al., 2012, p. 1). Our results as well as other empirical studies (Binsardi \& Ekwulugo, 2003; Boeri et al., 2012; Constant \& D'Agosto, 2008; De Grip et al., 2009; Soutar \& Turner, 2002) show that career prospects matter most to attract the highly-skilled, which provides clear policy implications. Improving the access to the labour market for foreign workers and transition from studying to the local labour market would cover the missing link in placing continental Europe more visibly on the map of global race for talent. 


\section{Conclusions}

Europe becomes more and more aware that it needs highly-skilled migrants. Faced with social and economic problems European countries are forced to reconsider immigration from third countries and accept it as one of the solutions for addressing some of these problems. This dissertation reviews how national migration policies and country-specific factors in receiving countries attend to a potential highly-skilled migrant when one is deciding among several possible locations.

The focal question addressed by this dissertation was motivated by the heightened sense of recognition with respect to the role highly-skilled immigrants can play in knowledge-based economic development strategies. That highly-qualified migrants can boost the contributions to innovation to keep Europe from progressively loosing markets for its products and services, is clearly stated in the European policy documents and a commonly-shared opinion among experts in the field (Kahanec \& Zimmermann, 2011; Zimmermann, Bonin, Fahr, \& Hinte, 2007). The Lisbon Strategy for Growth and Employment from 2000 and its midterm review in 2010 (COM, 2010b) both emphasize the need for knowledge-based economic growth and employment, especially in the face of crisis. Other, not unrelated challenges, which Europe is faced with recently, continuously press European countries to reconsider immigration from third countries and accept it as one of the solutions for addressing the social and economic problems. Decreasing competitiveness, cashstrapped public finances, ageing populations, shrinking labour force and shortages in certain sectors stress the importance of weighing migration seriously in the broader policy mix addressing these problems (Zimmermann, 2009). In the situation when working age population is declining at a fast pace (Fargues, 2011), the European Commission predicts a shortage of about one million health professionals for 2020 and a shortage of between 384,000 to 700,000 information and communication technology experts by 2015 (COM, 2010a). Labour shortages persist despite high unemployment rates in several European countries and the crisis is not expected to systematically change conditions in European labour markets (Kahanec \& Zimmermann, 2011). The European Union sees labour migration between European Union countries as the main approach to respond to the challenges of labour market shortages, but even with the downturn of the European economies the need for non-EU skilled labour remains a salient feature of European economies. As the internal mobility within the European Union remains low at merely 3 percent of working-age EU citizens living in another Member State than the one where they were born, immigration from outside the European Union signifies an obvious solution: immigration from outside the EU is already larger than cross-border migration within the EU (OECD, 2012, p. 63). 
However, immigration to the EU is predominantly low-skilled, especially when compared with the skills composition of immigrants to the traditional immigration countries.

This dissertation illustrates the general recognition that the ability to manage labour flows attracting "desirable" immigration and discouraging "unwanted" migration is considered to be a key component in the economic strategy for the countries under study. It has however remained unclear to what extent this recognition, which has been translated into more open immigration policies, led to actually turning European countries to perform better at the global competition for the highly-skilled. The understanding of the evolving policy and institutional framework for skilled migration is largely limited to traditional immigration countries, while the new dynamics in Europe were hardly covered in the academic literature (Avato, 2009; Cerna, 2013; Shachar, 2006; Zaletel, 2006). The limited available literature tells us little about how the European immigration policies compare on paper in terms of "attractiveness" for potential highly-skilled migrants, nor does it offer us an insight into how the reformed, relatively open immigration policies were received by the potential migrants. The purpose of this dissertation was to study the altered situation in the battle for talent, where many industrialized countries are changing their policies and to add to our knowledge of the process on how skilled migrants rationalize their migration decisions and if policy changes in prospective destination countries matter in this process.

In order to address this objective, two distinct approaches were utilized, which is reflected also in the composition of the dissertation. The first part of the dissertation employs qualitative material such as legal documents, government publications and academic literature discussing migration determinants and specifically, the role of migration policies within this process. The second part of the thesis is an empirical case study using qualitative and quantitative research methods. A quantitative survey and in-depth interviews are utilized to help us understand the drivers of international student mobility and learn how potential future migrants think of their destination options. Both parts together help us understand the potential of European countries as actors in the skilled migration field.

In this final chapter of the dissertation, I re-examine the main findings of both parts of the dissertation and assess the contributions to the existing knowledge. I provide policy implications regarding highly-skilled migration based on the main findings of this research. This chapter finally offers possible limitations of this approach and gives suggestions for future research. 


\subsection{Main findings}

The introduction of the dissertation points to the non-straightforward relationship between immigration policies and migration decision-making. It advocates the position that the role of the state in highly-skilled migration is in attracting potential migrant and that it is the individual who is in the position of choosing among several possible locations. As migration management in destination countries is mainly seen a concern of controlling migration, most studies on migration determinants and the role of policies are conducted with an interest of studying effectiveness in terms of restricting the flows and not in terms of encouraging them (Hatton, 2004; Thielemann, 2004).

Chapter 2 outlines the analytical approach which combines implication from a set of theories with relevance for determining migration flows of highly-skilled migrants. By introducing determinants stemming from literature on amenities (Florida, 2002; Graves, 1979) or self-selection process (Borjas, 1987), the presented conceptual framework is adapted to considerations of skilled migrants, who are considered to value specific kinds of cultural and financial incentives. The summary of implication stemming from theories shows that the state can intervene in migration management in a number of ways, either economic, social or cultural, and that several of the mentioned ways point to state intervention beyond tailoring migration policies.

An analytical approach, sketched from the theory overview is followed in the remainder of the dissertation. Identified determinants for skilled migration and the role of the state in affecting the specific determinants is used in Chapter 3 to identify a set of immigration policy dimensions. Those are grouped in five broader policy aspects: 1) eligibility criteria, 2) provisions for young migrants and students, 3) temporal validity of permits and possibility to obtain a permanent residence permit, 4) options for family reunion and 5) employment and social security provisions. A systematic comparison between three European countries (The United Kingdom, The Netherlands and Germany) with their main competitor in skilled migration (The United States) shows that, without trying to overly generalize the complex picture, the United States no longer sets a particularly favourable example. In certain aspects of immigration policy, the observed European countries are assessed as being more attractive for skilled foreign workers than the United States. The European countries have developed favourable rules for young migrants and former students to transition to the local labour market as labour migrants. Also, unlike in the United States, spouses are allowed to work in the host country. Counter to the general public perception, which sees Europe as "Fortress Europe" and the United States as an immigrant-friendly country, the observed EU 
Member States are found to be at least as attractive for highly-skilled immigrants in terms of immigration policies. In particular, Germany and the Netherlands have taken some valuable practical measures to open up their job markets to skilled workers from third countries. Examples of such are the Federal Law on Recognition of Foreign Qualifications in Germany which allows for reviewing foreign qualifications relative to German equivalents or the introduction of a short residence as knowledge migrants in the Netherlands. While the United Kingdom tightened eligibility rules in 2011, these two countries are going in the opposite direction. The Netherlands stands out in comparison with other countries in its favouring of young professionals, who still face obstacles for immigration in income threshold in Germany (OECD, 2013b, p.27). Both countries have, however, introduced measures for easier transition from studies to the job market by allowing for job-searching periods after graduation, which is no longer an option in the United Kingdom. Likewise, new legal routes for third-country nationals enable residence in Germany and the Netherlands even without a prior job offer.

Chapter 4 foregrounds the development of recent Dutch migration policies that display a persistent trend of facilitating entry of skilled migrants and closure of options for other migrant groups. With the Modern Migration Policy which came into force in June 2013 the government stresses the enforcedly temporary character of migration for certain groups of migrants, who are allowed to stay for a strictly limited period. In contrast, migrants within a knowledge sector get the most preferential treatment, are not subject to labour market tests and obtain extendable residence permits. The current situation, with a relatively low share of foreign skilled workers in The Netherlands, results mainly from the past colonialism and labour migration in the late 1960s and early 1970s, which was followed by migration of whole families. After insistent regulatory effort to cut down on family migration, labour is since 2007 again the most prominent migration motive, although this time with a different composition of sending countries. Much of the recent increase in immigration can be attributed to intra-EU migration. In addition, a high increase in immigration from India is noticeable. The Knowledge Migrant Scheme, reflecting to the needs for non-EU skilled labour, facilitates the entry for migrants from non-traditional sending countries. Indian migrants-young, working predominantly in technology sectors, and typically staying for short-term spansare emblematic of the category of migrants the Netherlands aims to attract.

The second part of the thesis looks specifically in the case of potential skilled migrants from India and in the unfolding of migration project. This dissertation is about a specific group of migrants, for which we assume they have the privilege of being able to choose the destination of their liking. There are other channels through which migrants are more directly guided, as for example those moving 
through the networks of transnational corporations or those approached by national or transnational recruitment agencies. Our findings from Chapter 6 confirm that going abroad for work straight out of the university is very uncommon for science and engineering students. That is why steered migration via corporations and recruitment agencies is less likely to happen in the case of the study population. More common paths are either going abroad for advanced studies or are being sent abroad by a company in India, after first having some work experience. Male students coming from research universities, whose parents encourage their move abroad and who have either parents or colleagues who have lived abroad are most likely to make plans to go abroad. They attribute a high importance to the level of income, the quality of educational institutions and an English-speaking environment. Professional aspects, related to work and further education are confirmed to be the most prominent in migration decision-making. Plans to settle down abroad for longer periods are rare, which influences what is considered as most important for their future destination. In the situation of planning a short-term stay abroad, social security services and benefits turn out to be less important in the decision making process. Likewise, the importance of an attractive local environment turns out to be secondary. Placing high importance on the family-friendly environment is proven to keep students in the home country. Lack of finance for international mobility and lack of family support are found as the main barriers for going abroad.

In Chapter 7 I show that determinants of migration plans differ between desired destinations. The country image is found to have an effect on the decision making in international mobility which goes beyond the importance of university and programmes reputation. The main predictors of country preferences are fields of studies, level of educational programme, parents' support, networks of friends abroad, leading motive behind migration, command of English and area of residence in India. Continental European countries represent a new destination for Indian pre-departure students, which often entails new risks 22(De Haas, 2010, pp. 21-22). To overcome the risks and pick Europe as a destination, more resources and skills are necessary; be it in terms of existing networks abroad, higher educational level or better language skills. While European countries appear to be relatively attractive for study purposes, they are not perceived equally attractive as a place for a long-term stay. With less long-term migration initiatives to Europe, immigration policies and destination country-specific factors, chances to obtain citizenship and amenities of local environment become less relevant. 


\subsection{Interpretation of results}

"Fortress Europe", as Europe is commonly named to pronounce its restrictive immigration laws, can no longer be used as an appropriate metaphor for Europe's approach towards all types of migrants, especially not for skilled migrants. The doors of many EU countries are now readily open to highly-skilled migrants, which could fill labour shortages. However, the empirical study among pre-departure migrants in India shows that the new policies and public policy discourses have not been overly effective in achieving the stated objective of becoming more attractive for highly-skilled migrants. As shown in the case of the Netherlands the number of third-country migrants from origin countries known for being a source of skilled foreign labour has increased with the introduction of selective policies. But when potential migrants In India were addressed with the question of preferred destination countries, the continental European countries lagged far behind the United States in terms of perceived overall attractiveness. While the particularities of the Indian case need to be recognized, the United States is found to persist as the single most important country in terms of study and career destinations. Despite the increasingly louder alarms coming from the United States that it is losing its triumphant position in competition for the skilled people around the world (Wadhwa, 2012), this research reveals this is not the case. Highlighting the case of India, which is one of the most important emigration countries, it shows the United States close to synonymous with the decision of going abroad. Several possible reasons may explain the persistence of one dominant destination country and lack of success of other contenders to challenge its position in the eyes of prospective skilled migrants.

The four decades long history of skilled migration from India to the United States emerged into a migration system which perpetuates itself and encourages migration along certain corridors (Mabogunje, 1970). Path dependency can explain why most people follow earlier migrants to the same destinations and why it is so difficult for the non-traditional countries to challenge this geographical structure. None of the individual European countries can be considered to stand in the position of being even compared one-on-one with a much greater American labour market. For that reason, continental European countries were grouped together in the applied empirical strategy to compare similarly-sized destination areas. Although this may hold ground in terms of methodology, fragmentation of the European labour market and the associated lack of free movement between countries for third-country nationals remain arguably one of the serious challenges of transforming EU Member States into more attractive destination countries. While access to the American labour market allows migrants to move freely across the country, in Europe migrants are obliged to undertake another application 
process if they want to move from one to another EU Member State. Even though EU Member States developed national immigration policies to the extent that individually countries have more open migration policies than the Unites States, they are constrained by the difficulty of internal mobility within the EU. The EU cannot yet be considered a single labour market for migrants. It still is the sum of several smaller countries, which is each less attractive than the much bigger USA with the labour force of around 150 million people.

Moreover, country image and public perception does not work in favour of European attractiveness. With the already mentioned metaphor "Fortress Europe" being the common expression used to describe Europe's approach towards migration, it is safe to assert that the restrictionist discourse Europe leads towards migration as a whole has unintended consequences also for the category of migrants which is not planned to be targeted by this message. European governments place considerable effort on integration of student migration as a part of a wider immigration strategy. International students are valued not only for their contributions to creating an international context in higher education but also for having a potential role in meeting research agendas and labour market needs in host countries (Kuptsch, 2006; Vincent-Lancrin, 2008). This strategy is likely to prove ineffective if "probationary immigrants" (Millar \& Salt, 2007) clearly do not see European countries as prospective work destination for the period after their graduation. It is more likely to happen that after they finish their education in Europe, they will move on to a third country, most likely the United States. The perception of Europe as only an attractive short-term migration destination is a reflection of Europe's stress on temporariness of immigration and limitations for long-term migration, especially for the low-skilled. At the same time, this focus reduces the relevance of several elements in the immigration policies which were included with the objective to increase attractiveness for high-skilled migrants for longer periods. In the situation when the motivation for moving abroad is exclusively limited to completion of a short-term project, be it study or work, many of the favourable options introduced in the recent versions of immigration policies to attract highly skilled migrants do not matter to a large extent. Access to social security and benefits, admission criteria as well as factors related to social contacts are not placed on par in importance with comparison with career path considerations. The decision to go abroad is guided by professional motives and economic factors override institutional and socio-political factors in migration decisions (Mahmood \& Schömann, 2003a). Extending the conceptual framework to the elements suggested by the New Economics of Labour Migration and amenity literature does not appear to utterly change the overall picture that international mobility is, at least in the Indian case, headed by career considerations. In addition to changing immigration policies, European countries have to change the 
perception of career possibilities, which can best be done with real examples of successful immigrant stories. Likewise, the direct branding and marketing of Europe as attractive long-term destination for (Indian) highly-skilled migrants should be increased. This research shows that the potential migrants simply do not know how attractive Europe is in their specific case.

That policies of European countries cannot be considered entirely effective could be due to the possible delay before the intended message of the policy reaches the target audience. Simply more time might be needed for Europe to change the perceptions of migrants. As the efforts of European countries to change their image of seeming unattractiveness into one encouraging high-skilled migration are quite recent, success of this change might not be measureable yet. It is difficult to challenge the dominance of the USA, which has been the main destination for Indian skilled migration for generations. Changing this dominance might be a gradual change, requiring time.

This dissertation adds to the understanding that even though immigration policies expectedly have "some" effect (De Haas, 2011), its relative importance from the perspective of the potential migrants is of secondary importance compared to career motivations. This might be different when prospective migrants from another origin country would be taken as a case study. If the study was about prospective migrants with little options for return to a home country, it is likely that they would place higher importance on options for settlement abroad and on security concerns. While there are particularities of Indian case study, the mobility patterns here show a changing picture but with a persistent dominance of one traditional destination country. Migration corridor of skilled migration between two countries is set by much more than migration policies. The other factors which turn out to be more relevant for location choice interact with migration policies and if favourable, migration policies can slowly respond to economic and political forces. Despite a changed immigration policy landscape in Europe it is hard to say that an increase in skilled migration will follow.

Significant potential for improving the recognized obstacles of the European countries lies in addressing the problem of fragmented European labour market, which unfortunately failed to be solved by the Blue Card Directive. Besides addressing the size of the labour market with further reforms, several other factors which contribute to the disadvantaged position of continental European countries need to be addressed. Governments can certainly shape the institutions and processes that provide the link between potential migrants and employers. By fostering exchange between countries social networks can be created which could counteract the limited historical ties with several important sending countries of skilled labour. However, this is not a process which could be changed within a short 
time. The fear that the EU policy change in migration will not result in an inflow of more high-skilled migrants, as expressed in the quote attributed to the Swedish Minister for Migration and Asylum in 2008 at the very beginning of this thesis, may well be justified. Changing bits and pieces of the immigration policy does not lead to desired results. What is needed is a major overhaul of immigration policies. 


\section{Bibliography}

Ackers, L. (2005). Moving People and Knowledge: Scientific Mobility in the European Union. International Migration, 43(5), 99-131.

Ackers, L., \& Gill, B. (2005). Attracting and Retaining 'Early Career' Researchers in English Higher Education Institutions. Innovation, 18(3), 277-299.

Advies Commissie Arbeidsparticipatie. (2008). Naar een toekomst die werkt. Den Haag: Advies Commissie Arbeidsparticipatie.

Ajzen, I. (2000). The Theory of Planned Behavior: . Organizational Behaviour and Human Decision Processes, 50(2), 179-211.

Ajzen, I., \& Fishbein, M. (1980). Understanding attitudes and predicting social behavior. Englewood Cliffs, N.J.: Prentice-Hall.

Almond, G. A., \& Powell, G. B. (1978). Comparative Politics: System, Process, and Policy. Boston: Little, Brown.

Amersfoort, H. v. (1999). Migration Control and Minority Policy: The Case of the Netherlands. In G. Brochmann \& T. Hammar (Eds.), Mechanisms of Immigration Control. A Comparative Analysis of European Regulation Policies (pp. 135-167). Oxford/New York: Berg.

Amersfoort, H. v. (2006). Immigration as a Colonial Inheritance: Post-Colonial Immigrants in the Netherlands, 1945-2002. Journal of Ethnic and Migration Studies, 32(3).

Amersfoort, H. v. (2011). How the Dutch Government stimulated the unwanted immigration from Suriname. IMI Working Paper, Paper 47.

Anderson, C., \& Stark, C. (1985). Emerging Issues From Job Relocation In the High Tech Field: Implications for Employee Assistance Programs. Employee Assistance Quarterly, 1(2), 37-54.

Antecol, H., Cobb-Clark, D. A., \& Trejo, S. J. (2003). Immigration Policy and the Skills of Immigrants to Australia, Canada, and the United States. Journal of Human Resources, 38(1), 192-218.

Aumüller, J. (2004). Migration and Development Aid Policy. In J. Blaschke (Ed.), Migration and Political Intervention. Theories and Debates. Berlin: PARABOLIS.

Avato, J. (2009). Dynamics in Highly Skilled Migration: A European Perspective. (Doctoral disertation Doctoral disertation), Eberhard Karls Universität Tübingen.

Bakewell, O., de Haas, H., \& Kubal, A. (2011). Migration systems, pioneers and the role of agency. IMI Working Paper. International Migration Institute. Oxford.

Bal, E. (2012). Country Report: Indian migration to the Netherlands. In Migration Policy Centre (Ed.), CARIM-India Research Report (Vol. 2012/07). Florence: Migration Policy Centre.

Balaz, V., Williams, A. M., \& Kollar, D. (2004). Temporary versus Permanent Youth Brain Drain: Economic Implications. International Migration, 42(4), 3-32. 
Beine, M., Docquier, F., \& Caglar, O. (2009). Diasporas. Université Catholique de Louvain, IRES Discussion Paper(2).

Beine, M., Docquier, F., \& Rapoport, H. (2003). Brain Drain and LDC's Growth: Winners and Losers. IZA Discussion Paper, 819.

Belot, M. V. K., \& Hatton, T. J. (2008). Immigration Selection in the OECD. CEPR Discussion Paper (571).

Bhagwati, J. N. (1976). The brain drain. International Social Science Journal, 28, 691-729.

Bhagwati, J. N., \& Hamada, K. (1974). The Brain-Drain, International Integration of Markets for Professionals and Unemployment. Journal of Development Economics, 1, 19-42.

Bhagwati, J. N., \& Wilson, J. D. (1989). Income Taxation and International Mobility. Cambridge: MIT Press.

Biffl, G. (2012). Labour market integration of low skilled migrants in Europe: economic impact. Paper presented at the Conference on Managing Migration and Integration: Europe and the US, University of California, Berkeley

Binsardi, A., \& Ekwulugo, F. (2003). International marketing of British education: research on the student's perception and the UK market penetration. Marketing Intelligence \& Planning, 21(5), 318-327.

Böcker, A. (1994). Chain migration over legally closed borders: settled migrants as bridgeheadsand gatekeepers. Netherlands' Journal of Social Sciences, 30(2): 87106., 30(2), 87-106.

Boeri, T. (2008). Brain Gain: A European Approach, Introduction CESifo Forum, 9 (3), 30-34.

Boeri, T., Brücker, H., Docquier, F., \& Rapaport, H. (2012). Brain Drain and Brain Gain: The Global Competition to Attract High-Skilled Migrants. Oxford: Oxford University Press.

Böhning, W. R. (1996). Employing foreign workers: a manual on policies and procedures of special interest to middle and low-income countries. Geneva: International Labour Office.

Bonjour, S. (2005). The Politics of Migration and Development: The Migration development Connection in Dutch Political Discourse and Policy Since 1970. Paper presented at the Florence School on Euro-Medditerranean Migration and Development, Florence.

Bonjour, S. (2006). Who is in and who is out? The postwar politics and policies of family migration in the Netherlands. Paper presented at the ESSHC Conference, Amsterdam.

Borjas, G. (1993). Immigration Policy, National Origin, and Immigrant Skills: A Comparison of Canada and the United States. In D. E. Card \& R. B. Freeman (Eds.), Small Differences That Matter: Labor Markets and Income Maintenance in Canada and the United States (pp. 21-43). Chicago: University of Chicago Press. 
Borjas, G. J. (1987). Self-selection and the Earnings of Immigrants. American Economic Review, 77(4), 531-553.

Borjas, G. J. (1999). Immigration and Welfare Magnets. Journal of Labor Economics, 17(4), 607-637.

Bourke, A. (2000). A model of the determinants of international trade in higher education. The Service Industries Journal, 20(1), 110-138.

Bouvier, L. F. (2001). 'Replacement Migration: Is it a Solution to Declining and Aging Populations?' Population and Environment, 4, 377-381.

Bresnahan, T. F., Brynjolfsson, E., \& Hitt, L. M. (1999). Information technology, workplace organization, and the demand for skilled labor: firm-level evidence. Cambridge Mass: National Bureau of Economic Research.

Bruquetas-Callejo, M., Garcés-Mascareñas, B., Penninx, R., \& Scholten, P. (2007). Policymaking related to immigration and integration. The Dutch Case. IMISCO Working Paper(15).

Bundesministerium des Inneren. (2006). Bericht zur Evaluierung des Gesetzes zur Steuerung und Begrenzung der Zuwanderung und zur Regelung des Aufenthalts und der Integration von Unionsbürgern und Ausländern (Zuwanderungsgesetz). (2006: 27-29).

Cant, A. G. (2004). Internationalizing the business curriculum: developing intercultural competence. Journal of American Academy of Business, 5(1/2), 177-182.

CAS. (1994). Guidance for Adjudication Officers: Income Support. Habitual Residence Test. Memo AOG, 3(July 1994).

Castles, S. (Ed.). (2008). Comparing the Experience of Five Major Emigration Countries. Geneva: IOM.

Cattaneo, C. (2007). The Self-Selection In The Migration Process: What Can We Learn? Liuc Papers, Serie Economia e Impresa, 199(52).

Cerna, L. (2007, May 17-19). The Varieties of High-Skilled Immigration Policies: Sectoral Coalitions and Outcomes in Advanced Industrial Countries. Paper presented at the the European Union Studies Association Conference, Montreal.

Cerna, L. (2008). Towards an EU Blue Card?: The delegation of national high skilled immigration policies to the EU level. COMPAS Working Paper WP-08-65. http://www.compas.ox.ac.uk/fileadmin/files/Publications/working_pape rs/WP_2008/WP0865\%20Cerna.pdf

Cerna, L. (2013). Understanding the diversity of EU migration policy in practice: the implementation of the Blue Card initiative. Policy studies, 34(2), 180 200.

Cerny, P. (1996). International Finance and the Erosion of Capitalist Diversity. In C. C. a. W. Streeck (Ed.), Political Economy of Modern Capitalism: Mapping convergence and Diversity (pp. 173-181). London: Sage.

Chanda, R., \& Sreenivasan, N. (2006). India's exeprience with skilled migration. In K. Kuptsch \& E. F. Pang (Eds.), Competing for Global Talent (pp. 215-255). Geneva: International Institute for Labour Studies. 
Chang, T. H. P. (1981). A review of micro migration research in the third world context. In G.F. De Jong \& R. F. Gardner (Eds.), Migration decision making: multidisciplinary approaches to microlevel studies in developed and developing countries. New York: Pergamon Press.

Checchi, D. (2006). The Economics of Education: Human Capital, Family Background and Inequality. Cambridge annd New York: Cambridge University Press.

Chiswick, B. R., \& Miller, P. W. (1999). Language Skills and Earnings among Legalized Aliens. Journal of Population Economics, 12(1), 63-89.

Christian, B. P. (2000). Facilitating High-Skilled Migration to Advanced Industrial Countries: Comparative Policies. Working Paper of the Institute for the Study of International Migration: Georgetown University.

Clark, X., Hatton, T. J., \& Williamson, J. G. (2002). Where Do U.S. Immigrants Come From, and Why? NBER Working Paper, 8998.

Cobb-Clark, D. A., \& Connoly, M. (1997). The Worldwide Market for Skilled Migrants: Can Australia Compete? International Migration Review, 31(3), 130-153.

Collinson, S. (2009) The political economy of migration processes: an agenda for migration research and analysis. Vol. 12. IMI Working Papers. Oxford: International Migration Institute, University of Oxford.

COM. (2010a). An Agenda for New Skills and Jobs: A European Contribution Towards Full Employment Communication from the Commission (Vol. COM (2010) 682 final). Brussels: European Commission

COM. (2010b). Europe 2020: A strategy for smart, sustainable and inclusive growth Communication from the Commission (Vol. COM(2010) 2020 final). Brussels: European Commission.

Commander, S., Kangasniemi, M., \& Winters, L. A., (2004). (2003). The Brain Drain: Curse or Boon? IZA Discussion paper series, 809.

Constant, A., \& Massey, D. S. (2002). Return Migration by German Guestworkers: Neoclassical versus New Economic Theories. International Migration, 40(4), 5-38.

Constant, A. F., \& D'Agosto, E. (2008). Where Do the Brainy Italians Go? IZA Discussion Paper, 3325.

Cornelius, W. A., Philip, L. M., \& Hollifield, J. F. (1994). Introduction: The Ambivalent Quest for Immigration Control. In W. A. Cornelius, L. M. Philip \& J. F. Hollifield (Eds.), Controlling Immigration: A Global Perspective. Stanford: Stanford University Press.

Cörvers, F., Muysken, J., de Neubourg, C., \& Schliwen, A. (Eds.). (2009). Arbeidsmigratie (Vol. Cahiers 2009 - 03). Den Haag: WODC/Maastricht University.

Cubilo, J. M., Sanchez, J., \& Cervino, J. (2006). International students' decisionmaking process. International Journal of Educational Management, 20(2), 101-115. 
Czaika, M., \& De Haas, H. (2011). The effectiveness of immigration policies: A conceptual review of empirical evidence. IMI Working Papers, 33(April 2011).

Davis, K. (1951). The Population of India and Pakistan. Princeton, NJ: Princeton University Press.

De Giorgi, G., \& Pellizzari, M. (2006). Welfare Migration in Europe and the Cost of a Harmonised Social Assistance. IZA Discussion Paper, 2094.

De Graaf, D., Heyma, A., \& Van Klaveren, C. (2007). De arbeidsmarkt van hoger opgeleide beta's. Amsterdam: SEO Economisch Onderzoek.

De Grip, A., Fourage, D., \& Sauermann, J. (2009). What Affect International Migration of European Science and Engineering Graduates? IZA Discussion Paper, 4268.

De Haas, H. (2007). Between courting and controlling: The Moroccan state and 'its' emigrants,. Center on Migration, Policy and Society, University of Oxford Working paper, 54.

De Haas, H. (2010). The Internal Dynamics of Migration Processes: A Theoretical Inquiry. Journal of Ethnic and Migration Studies, 36(10), 1587-1617.

De Haas, H. (2011). The determinants of international migration: Conceptualizing policy, origin and destination effects. IMI Working Paper, 32(April 2011).

De Jong, A., \& Van Duin, C. (2011). Regionale bevolkings- en huishoudensprognoses 2011-2040: sterke regionale contrasten. The Hague PBL Netherlands Environmental Assessment Agency/Statistics Netherlands.

De Jong, G. F. (2000). Expectations, Gender, and Norms in Migration DecisionMaking. Population Studies, 54(3), 307-319.

De Jong, G. F., Davis Root, B., Gardner, R. W., Fawcett, J. T., \& Abad, R. G. (1985). Migration Intentions and Behavior: Decision Making in a Rural Phillipine Province. Population and Environment, 8(1-2), 41-62.

Desai, M. A., Kapur, D., McHale, J., \& Rogers, K. (2009). The fiscal impact of highskilled emigration: Flows of Indians to the U.S. Journal of Development Economics, 88(1), 32-44.

DHS. (2012, January 31 ). DHS Reforms To Attract And Retain Highly Skilled Immigrants. DHS online news, www.dhs.gov.

Docquier, F., Lohest, O., \& Marfouk, A. (2006). What determines migrants' destination choice? Working paper, IRES - Université Catholique du Louvain. Working paper. IRES - Université Catholique du Louvain

Docquier, F., Lowell, A., \& Marfouk, B. L. (2007). A Gendered Assessment of the Brain Drain. IZA Discussion Paper, 3235.

Doomernik, J. (2007). De moeizame omgang met arbeidsmigratie. In IOM (Ed.), IOM Nederland Jaarverslag 2006 (pp. 3-20). The Hague: IOM.

Doomernik, J., Gsir, S., \& Kraler, A. (2005). Prospects on Migration Management Opportunities and Pitfalls. In IMISCOE (Ed.), International migration and its regulation. State of the art report Cluster A1 (pp. 35-46). Amsterdam: IMISCOE. 
Duin, C. v., \& Nicolaas, H. (2006). Analysemodellen immigratie. Notitie ten behoeve van het overleg van het Demografieplatform over de migratieprognose. In CBS (Ed.). Voorburg: CBS.

Dumont, J. C., Martin, J. P., \& Spielvogel, G. (2007). Women on the Move: the Neglected Gender Dimension of the Brain Drain. IZA Discussion Paper, 2920.

Entzinger, H. B. (1985). The Netherlands In T. Hammar (Ed.), European immigration policy. A comparative study (pp. 50-88). Cambridge: Cambridge University Press.

Epstein, G. S. (2008). Herd and network effects in migration decision-making. Journal of Ethnic and Migration Studies, 34(4), 567-583.

Ersanili, E. (2007). Country Profile: The Netherlands In HWWI (Ed.), Focus Migration Country Profile. Hamburg: Hamburg Institute of International Economics.

Faggian, A., MCCann, P., \& Sheppeard, S. C. (2007). Some Evidence that Women are More Mobile than Men: Gender Difference in UK Graduate Migration Behaviour. Journal of Regional Science, 47(3).

Fargues, P. (2011). International Migration and Europe's Demographic Challenge EU-US Immigration Systems (Vol. 2011/09): European University Institute.

Fawcett, J. T. (1989). Networks, Linkages, and Migration Systems. International Migration Review, 23(3), 671-680.

Feld, L. P., \& Kirchgässner, G. (2001). The impact of corporate and personal imcome taxes on the location of firms and on employment: some panel evidence for the Swiss cantons. Journal of public economics., 87(1), 129155.

Findlay, A. M. (2010). An Assessment of Supply and Demand-side Theoretizations of International Student Mobility. International Migration, 49(2).

Findlay, A. M., Stam, A., King, R., \& Ruiz-Gelices, E. (2005). International opportunities: searching for the meaning of student migration Geographica Helvetica, 60(3), 192-200.

Finn, M. (2003). Stay Rates of Foreign Doctorate Recipients from U.S. Universities. Oak Ridge: Oak Ridge Institute for Science and Education.

Flick, U. (2006). An Introduction to Qualitative Research (3rd ed.). London, Thousand Oaks: Sage.

Florida, R. L. (2002). The Rise of the Creative Class: and how it's transforming work, leisure, community and everyday life. New York, NY: Basic Books.

Florida, R. L. (2005). The Flight of the Creative Class: the New Global Competition for Talent. New York: Harper Business.

Flynn, D. (2006). The Rights of Migrant Workers in the United Kingdom. In R. Plaetevoet (Ed.), The Right of Migrant Workers in the European Union (pp. 82-97). Brussels: European Platform for Migrant Workers' Rights.

Frank, A. G. (1966). The Development of Underdevelopment. Monthly Review, $18(4), 23-28$. 
Frattini, F. (2007, 13 September 2007). Enhanced mobility, vigorous integration strategy and zero tolerance on illegal employment: a dynamic approach to European immigration policies. Paper presented at the High-level Conference on Legal Immigration, Lisbon.

Freeman, G. P. (2003). Political Science and Immigration: Policy Types and Modes of Politics. Paper presented at the Carney Lecture Series, Universtiy of Toronto.

Freeman, R. B. (2006). Does Globalization of the Scientific/Engineering Workforce Threaten U.S. Economic Leadership? Innovation Policy and the Economy, NBER Chapters, 6, 123-158.

Frieze, I. H., Boneva, B. S., Sarlija, N., Horvat, J., Ferligoj, A., Kogovsek, T., . . . Jarosova, E. (2004). Psychological Differences in Stayers and Leavers: Emigration Desires in Central and Eastern European University Students. European psychologist, 9(1), 15.

Gardner, R. W., De Jong, G. F., Arnold, F., \& Carino, B. V. (1985). The Best-Laid Schemes: An Analysis of Discrepancies Between Migration Intentions and Behavior. Population and Environment, 8(1-2), 63-77.

Gayathri, V. (2001). Rethinking high-skilled international migration: research and policy issues for India's information economy in OECD. In OECD (Ed.), International Mobility of the Highly Skilled (pp. 201-212). Paris: OECD.

Geddes, A. (2003). The politics of migration and immigration in Europe. London: SAGE Publications.

Geis, W., Uebelmesser, S., \& Werding, M. (2008a). How Do Migrants Choose Their Destination Country? An Analysis of Institutional Determinants. CESifo Working Paper, 2506.

Geis, W., Uebelmesser, S., \& Werding, M. (2008b). Why go to France or Germany, if you could as well go to the UK or the US? Selective Features of Immigration to four major OECD Countries. CESifo Working Paper, No. 2427.

Gibson, J., \& McKenzie, D. (2009). The Microeconomic Determinants of Emigration and Return Migration of the Best and the Brightest: Evidence from the Pacific. IZA Discussion Paper, 3926.

Giri, D. K. (2001). Indians in Europe. In B. Vivekanandan \& D. K. Giri (Eds.), Contemporary Europe and South Asia (pp. 179-191). New Delhi: Concept Publishing Company.

Government of India, P. I. B. (2008, March 28). States Identified for locating New Central Institutions of Higher Education in the 11th five year plan (Press release) Retrieved from http://pib.nic.in/release/release.asp?relid=36955.

Granovetter, M. S. (1973). The Strength of Weak Ties. American Journal of Sociology, 78(9), 136080.

Graves, P. E. (1979). A Life-Cycle Empirical Analysis of Migration and Climate, by Race. Journal of urban economics, VI, 135-147. 
Graves, P. E., \& Linneman, P. D. (1979). Household Migration: Theoretical and Empirical Results. Journal of urban economics, VI(3), 383-404.

Graves, P. E., \& Regulska, J. (1982). Amenities and Migration over the Life-Cycle, by Race. In D. B. Diamond \& G. S. Tolley (Eds.), The Economics of Urban Amenities (pp. 211-222). New York: Academic Press.

Green, A. G., \& Green, D. A. (1995). Canadian Immigration Policy: The Effectiveness of the Point System and Other Instruments. The Canadian journal of economics. Revue canadienne d'économique, 28(4b), 1006-1041.

Greenbury, L., \& Shortland, S. (1996). Employee relocation and the dual career couple. Employee Relocation Report, 6, 11-14.

Grogger, J., \& Hanson, G. (2008). Income Maximization and the Selection and Sorting of International Migrants. NBER Working Paper Series 13821.

Grönroos, C. (1978). A service oriented approach to marketing of services. European Journal of Marketing, 8.

Grönroos, C. (1994). Quo vadis marketing? Towards a relationship marketing paradigm. Journal of Marketing, 10, 347-360.

Gross, D. M. (2006). Immigration to Switzerland: The Case of the Former Republic of Yugoslavia. World Bank Policy Research Working Paper, 3880.

Gross, D. M., \& Schmitt, N. (2006). Why do Low- and High-skill Workers Migrate? Flow Evidence from France. CESifo Working Paper, No. 1797.

Grubel, H. B., \& Scott, A. D. (1966). The International Flow of Human Capital. The American Economic Review, 56(1/2), 268-274.

Guellec, D., \& Cervantes, M. (2002). International mobility of highly skilled workers: from statistical analysis to policy formulation. In OECD (Ed.), International Mobility of the Highly Skilled (pp. 71-98). Paris: OECD Publishing.

Guth, J. (2007). Triggering Skilled Migration: Factors influencing the mobility of early career scientists to Germany. Hamburg Institute of International Economics (HWWI), Hamburg, Focus Migration Policy Brief, 6.

Hailbronner, K., \& Koslowski, R. (2008) Models for immigration management schemes: comparison and analysis of existing approaches and perspectives for future reforms. GMF Paper Series. Washington DC: The German Marshall Fund of the United States.

Haque, N. U., \& Kim, S. (1995). Human capital flight: impact of migration on income and growth. IMF Staff Papers, 42(2), 577-607.

Harris, J., \& Todaro, M. (1970). Migration, Unemployment \& Development: A TwoSector Analysis. American Economic Review, 60(1), 126-142.

Harvey, M. (1997). Dual-Career Expatriates: Expectations, Adjustment and Satisfaction with International Relocation. Journal of International Business Studies, 28(3), 627-658.

Harvey, M. G. (1995). The Impact of Dual-Career Families on International Relocations. Human Resource Management Review, 5(3), 223-244.

Hatton, T. J. (2004). Seeking Asylum in Europe. economic Policy, 19, 5-62. 
Hein, M., \& Plesch, J. (2008). How can scholarship institutions foster the return of foreign students? Diskussionspapier der Forschergruppe (Nr.: 3468269275) "Heterogene Arbeit: Positive und Normative Aspekte der Qualifikationsstruktur der Arbeit", 8(2).

Hercog, M. (2008). The Role of the State in Attracting Highly-Skilled Migrants: The Case of the Netherlands. EIPASCOPE, 3.

Hollifield, J. (2000). The politics of international migration: how can we "bring the state back in?". In C. Brettell \& J. F. Hollifield (Eds.), Migration theory: talking across disciplines. London: Routledge.

Hooley, G. J., \& Lynch, J. E. (1981). Modelling the student university choice process through the use of conjoint measurement techniques. European Research, 9(4), 158-170.

House of Commons. (2008). Statement of Changes in Immigration Rules of 6 February 2008, HC 321 and 4 November 2008, HC 113.

IND. (2012). Immigration and Naturalization Services. from http://www.ind.nl/

IND. (2013a). Coming to study in the Netherland. The Hague: Immigration and Naturalisation Service.

IND. (2013b). Coming to the Netherlands for a cultural exchange. The Hague: Immigration and Naturalisation Service.

IND. (2013c). Coming to work in the Netherlands. The Hague: Immigration and Naturalisation Service.

IND. (2013d). Modern Migration Retrieved 13 October 2013, from http://www.ind.nl/en/Themes/Modern-Migration/Frequently-AskedQuestions/Pages/default.aspx

IND. (2013e). Orientation year Highly Educated persons. Retrieved 13 October, 2013, from http://www.ind.nl/en/Residence-Wizard/work/orientationyear-highly-educated-persons/Pages/default.aspx\#paragraph1

IND. (2014). Costs and Income Requirements. Retrieved 10 February 2014, from https://ind.nl/EN/individuals/employee/costs-income-requirements/

INDIAC. (2013). Monitor Kennismigranten: Kwantitatieve analyse (Vol. June 2013). The Hague IND Informatie- en Analyscentrum.

IOM. (2008). World migration 2008 : managing labour mobility in the evolving global economy. Geneva, Switzerland: International Organization for Migration.

Ivy, J. (2001). Higher education institution image: a correspondence analysis approach. The International Journal of Educational Management, 15(6/7), 276-282.

Jaeger, D., Dohmen, T., Falk, A., Huffman, D., Sunde, U., \& Bonin, H. (2008). Direct Evidence on Risk Attitudes and Migration. ROA (Research Centre for Education and the Labour Market), Maastricht, Research Memoranda, 11. Johnson, H. G. (1967). Some Economic Aspects of Brain Drain. The Pakistan Development Review, 7(3), 379-411.

Kahanec, M., \& Zimmermann, K. F. (2011). High-Skilled Immigration Policy in Europe. In B. R. Chiswick (Ed.), High-skilled Immigration in a Globalized 
Labor Market (pp. 264-314). Washington DC: American Enterprise Institute.

Kanbur, R., \& Rapoport, H. (2005). Migration selectivity and the evolution of spatial inequality. Journal of Economic Geography, 5(1), 43-57.

Kapur, D. (2010). Diaspora, development, and democracy: the domestic impact of international migration from India. Princeton, NJ: Princeton University Press.

Kapur, D., \& McHale, J. (2005a). Give us your best and brightest: the global hunt for talent and its impact on the developing world. Washington, D.C.: Center for Global Development.

Kapur, D., \& McHale, J. (2005b). The Global Migration of Talent: What Does it Mean for Developing Countries? CGB Brief. Washington, D.C.: Center for Global Development.

Karemera, D., Oguledo, V. I., \& Davis, B. (2000). A Gravity Model Analysis of International Migration to North America. Applied Economics, 32, 17451755.

Khadria, B. (2004). Migration of Highly Skilled Indians: Case Studies of IT and Health Professionals. OECD Science, Technology and Industry Working Papers, 2004/06.

Khadria, B. (2009). Indian Migration Report 2009: Past, Present and Future Outlook. New Delhi: Jawaharlal Nehru University.

Khoo, S.-E., Hugo, G., \& McDonald, P. (2008). Which Skilled Temporary Migrants Become Permanent Residents and Why? International Migration Review, 42(1), 193-226.

King, R. (2002). Towards a new map of European migration. International Journal of Population Geography, 8, 89-102.

King, R., Ruiz-Gelices, E., \& Findlay, A. M. (2004). International Student Mobility Study: Study 2 - Exploring the Diversity of UK International Student Mobility. Brighton: Sussex Centre for Migration Research, University of Sussex.

Kirchgassner, G., \& Pommerehne, W. W. (1996). Tax harmonization and tax competition in the European Union: Lessons from Switzerland. Journal of public economics., 60(3), 351-371.

Kofman, E. (2000). The invisibility of skilled female migrants and gender relations in studies of skilled international migration in Europe. International Journal of Population Geography, 6, 45-49.

Konrad, H., Roads, M. B., \& Norman, E. (1997). A Practical Guide to EmploymentBased Immigration: The State of Employment-Based Immigration in the Wake of the Illegal Immigration Reform and Immigrant Responsibility Act of 1996. Race and Ethnic Ancestry Law Digest, 3(April 1997).

Körner, H. (1999). "Brain Drain” aus Entwicklungsländern In P. Marschalack (Ed.), IMIS-Beiträge, Nr. 11 (pp. 55-64). Osnabrück: ISIM.

Koser, K., \& Salt, J. (1997). The geography of highly skilled international migration. International Journal of Population Geography, 3(4), 285-303. 
Kritz, M. M., \& Zlotnik, H. (1992). Global Interactions: Migration Systems, Processes, and Policies. In M. M. Kritz, L. L. Lim \& H. Zlotnik (Eds.), International Migration Systems: A Global Approach. Oxford; New York: Clarendon Press ; Oxford University Press.

Krugman, P. (1996). Making sense of the competitiveness debate. Oxford Review of Economic Policy, 12(3), 17-25.

Krupka, D. J. (2007). Location-Specific Human Capital, Location Choice and Amenity Demand. IZA Discussion Papers, 2987(August 2007).

Kuhfeld, W. F., \& So, Y. (2007). Multinomial Logit Models. SAS Support Document: TS-722G.

Kuhn, P. J., \& McAusland, C. (2006). The International Migration of Knowledge Workers: When Is Brain Drain Beneficial? IZA Discussion Papers, 2493.

Kumar, P., Sarkar, S., \& Sharma, R. (2009). Migration and Diaspora Formation: Mobility of Indian Students to Developed Countries. IMDS Working Paper Series, 8(May 2009), 29-45.

Laudel, G. (2005). Migration currents among the scientific elite. Minerva, 43, 377395.

Levitt, T. (1980). Marketing success through differentiation of anything. Harvard Business Review, February, 83-89.

Li, F. L., Findlay, A. M., Jowett, A. J., \& Skeldon, R. (1996). Migrating to learn and learning to migrate: a study of the experiences and intentions of international student migrants. International Journal of Population Geography, 2(1), 51-67.

Liebig, T. (2003). Migration Theory from a Supply-side Perspective Discussion Paper 92: Research Institute for Labour Economics and Labour Law, University of St. Gallen, Switzerland.

Liebig, T., \& Sousa-Poza, A. (2005). Taxation, Ethnic Ties and the Location Choice of Highly Skilled Immigrants. OECD Social, Employment and Migration Working papers, No. 24.

Liebig, T., \& Souza-Poza, A. (2004). Migration, Self-Selection and Income Inequality: An International Analysis. Kyklos, 57(1), 125-146.

Lin, L. (1997). What are student education and educational related needs? Marketing and Research Today, 25(3), 199-212.

Lowell, L. (2001). Skilled temporary and permanent immigrants in the United States. Population Research and Policy Review, 20(1/2), 33-58.

Lowell, L. (2005). Policies and Regulations for Managing Skilled International Migration for Work. Paper presented at the United Nations Group Meeting on International Migration and Development, New York: United Nations.

Lu, M. (1999). Do People Move When They Say They Will? Inconsistencies in Individual Migration Behavior. Population and Environment, 20(35), 467488.

Lucas, R. E. (1988). On the mechanics of economic development. Journal of Monetary Economics, 22, 3-42. 
Lucassen, J., \& Penninx, R. (1997). Newcomers: Immigrants and their Descendants in The Netherlands 1550-1995. Amsterdam: Het Spinhuis.

Mabogunje, A. L. (1970). Systems Approach to a Theory of Rural-Urban Migration. Geographical Analysis, 2(1), 1-18.

Mahmood, T., \& Schömann, K. (2003a). Assessing the Migration Decision of Indian IT-Graduates: An Empirical Analysis. Discussion Paper Wissenschaftszentrum Berlin, SP II 2003 - 23.

Mahmood, T., \& Schömann, K. (2003b). On the Migration Decision of Indian ITGraduates. Wissenschaftszentrum Berlin, Discussion Paper SP, II(23).

Mahroum, S. (2000). Highly skilled globetrotters: mapping the international migration of human capital. R\&D Management, 30(1), 23-31.

Martin, R. (1996). A Longitudinal Study Examining the Psychological Reactions of Job Relocation. Journal of Applied Social Psychology, 26(3), 265-282.

Massey, D. S., Arango, J., Hugo, G., Kouaci, A., Pellegrino, A., \& Taylor, E. (1993). Theories of International Migration: A Review and Appraisal. Population and Development Review, 19(3), 431-466.

Mayda, A. M. (2005). International Migration: A Panel Data Analysis of Economic and Non-Economic Determinants. IZA Discussion Papers 1590.

Mayer, M. (2013). Attracting highly qualified and qualified third-country nationals. Working Paper of the Research Section of the Federal Office. Working Paper. Federal Office for Migration and Refugees. Nuremberg.

Mazzarol, T. (1998). Critical success factors for international education marketing. The International Journal of Educational Management, 12(4), 163-175.

McLaughlan, G., \& Salt, J. (2002). Migration policies towards highly skilled foreign workers. London: Great Britain Home Office.

Meissner, D. M., Meyers, D. W., Papademetriou, D. G., \& Fix, M. (2006). Immigration and America's Future: A New Chapter: Report of the Independent Task Force on Immigration and America's Future. Washington, DC: Migration Policy Institute.

Meyer, J.-B., Kaplan, D., \& Charum, J. (2001). Scientific nomadism and the new geopolitics of knowledge. International Social Science Journal, 53(168), 309-321.

Millar, J., \& Salt, J. (2007). In whose interests? IT migration in an interconnected world economy. Population, Space and Place, 13(41-58).

Mincer, J. (1978). Family Migration Decisions. The Journal of Political Economy, 86(5), 749-773.

Ministry of Human Resource Development (Government of India). (2009). Annual Report 2008-2009. New Delhi: Ministry of Human Resource Development, Government of India.

Ministry of Human Resource Development (Government of India). (2010). Annual Report 2009-2010. New Delhi: Ministry of Human Resource Development , Government of India. 
Ministry of Justice. (2006). Naar een modern migratiebeleid, Notitie over de herziening van de reguliere toelating van vreemdelingen in Nederland. The Hague: Ministry of Justice.

Ministry of Security and Justice. (2013). Rapportage Vreemdelingeketen: Periode januari - december 2012. In Ministry of Security and Justice (Ed.), Rapportage Vreemdelingeketen. The Hague: Ministry of Security and Justice.

Ministry of Social Affairs and Employment. (2008). Retrieved March 3, 2008, from http://internationalezaken.szw.nl/index.cfm?fuseaction=dsp_rubriek\&ru briek_id=190047\#top

Ministry of Social Affairs and Employment. (2009).

Mitchell, J., \& Pain, N. (2003). The Determinants of International Migration into the UK: A Panel Based Modelling Approach. National Institute of Economic and Social Research Discussion Papers(216).

Miyagiwa, K. (1991). Scale Economies in Education and The Brain Drain Problem. International Economic Review, 32, 743-759.

MOIA. (2010). Annual Report 2009-2010. New Delhi: Ministry of Overseas Indian Affairs, Government of India.

Munton, A. G. (1990). Job Relocation, Stress and the Family. Journal of Organizational Behavior, 11(5), 401-406.

Münz, R. (2009). Demographic Change, Labour Force Development and Migration in Europe -Current Situation, Future Outlook and Policy Recommendation. Paper presented at the importance of labour immigration Labour Migration and its Development Potential in the Age of Mobility, Swedish Presidency, Malmö, 15-16 October 2009.

Murphy-Lejeune, E. (2002). Student Mobility and Narrative in Europe. The new strangers. . London \& New York: Routledge.

NAAC. (2007). New methodology of Assessment and Accreditation. Bangalore:

Retrieved from http://www.naac.gov.in/Publications/methodology2007.pdf.

National Assessment \& Accreditation Council of India. (2010). Institutions accredited by NAAC under new GGPA methodology. Retrieved 23 August, 2010, from http://www.naacindia.org/CGPA_System_accredited_inst.pdf

NSB. (2010). Science and Engineering Indicators 2010. In N. S. Foundation (Ed.). Arlington, VA: National Science Foundation.

Nuffic. (2010). Mapping mobility 2010: International Mobility in Dutch Higher Education In Nuffic (Ed.). The Hague: Netherlands Organisation for International Cooperation in Higher Education.

Nuffic. (2011). Immigration procedures for foreign nationals seeking work in the Netherlands. Retrieved 13 October, 2013, from http://www.nuffic.nl/pdf/service/factsh/Factsheet_immigration_proced ures.pdf

Nuffic. (2013). Mapping Mobility 2013: International Mobility in Dutch Higher Education. The Hague: Nuffic. 
OECD. (2001). International Mobility of the Highly Skilled. In OECD (Ed.), Policy proceedings. Paris: OECD.

OECD. (2002). International mobility of the highly skilled. Paris: OECD.

OECD. (2004). Developing Highly Skilled Workers: Review of the Netherlands. Paris: OECD.

OECD. (2007). International Migration Outlook: Recent Trends in International Migration. . Paris: OECD.

OECD. (2010a). International Migration Outlook: Annual Report 2010. Paris: OECD.

OECD. (2010b). Table C2.2. Distribution of international and foreign students in tertiary education, by country of origin (2008) Education at a Glance 2010: OECD Indicators. Paris: OECD.

OECD. (2010c). Table C2.3. Citizens studying abroad in tertiary education, by country of destination (2008) Education at a Glance 2010: OECD Indicators. Paris: OECD.

OECD. (2010d). Table C2.7. Number of foreign students in tertiary education, by country of origin and destination (2008), and market shares in international education $(2000,2008)$ Education at a Glance 2010: OECD Indicators. Paris, France: OECD.

OECD. (2012). OECD Economic Surveys 2012. In OECD (Ed.), OECD Economic Surveys. Paris: OECD.

Oers, R. v., Hart, B. d., \& Groenendijk, C. A. (2006). Netherlands. In R. Bauböck, E. ErsbøII, C. A. Groenendijk \& H. Waldrauch (Eds.), Acquisition and Loss of Nationality. Policies and Trends in 15 European Countries. Volume 2: Country Analyses (pp. 391-434). Amsterdam: Amsterdam University Press. ONS. (2011). Annual Population Survey.

Ortega, F., \& Peri, G. (2009). The Causes and Effects of International Migrations: Evidence from OECD Countries 1980-2005. NBER Working Paper, 14833.

Papademetriou, D. (2003b). Immigrant Selection and Admission Systems: Lessons from the Traditional Countries of Immigration. Paper presented at the Department of Social Affairs of the Ministry of Labour and Social Policy, Como, Italian EU Presidency.

Papademetriou, D. G., \& Yale-Loehr, S. (1996). Balancing Interests: Rethinking U.S. Selection of Skilled Immigrants. Washington D. C.: Carnegie Endowment for International Peace.

Parey, M., \& Waldinger, F. (2008). Studying Abroad and the Effect on International Labor Market Mobility: Evidence from the Introduction of ERASMUS. IZA Discussion Paper, 3430.

Pedraza, S. (1991). Women and Migration: The Social Consequences of Gender. Annual Review of Sociology, 17, 303-325.

Peers, S. (2009). Attracting and Deterring Labour Migration: The Blue Card and Employment Sanctions Directives. European Journal of Migration and Law, 11, 387-426.

Peng, Z., Lawley, M., \& Perry, C. (2000). Modelling and testing effects of country, corporate and brand images on consumers' product evaluation and 
purchase intention. Paper presented at the ANZMAC 2000 Visionary Marketing for the 21st Century: Facing the Challenge Conference, Gold Coast, Queensland.

Penninx, R., Garcés-Mascareñas, B., \& Scholten, P. (2005). Policymaking related to immigration and integration: a review of the literature of the Dutch case. IMISCOE Working Papers.

Penninx, R., J. Schoorl, C. Van Praag (1994). The Impact of International Migration on Receiving Countries: the Case of the Netherlands. The Hague: NIDI.

Price, I. F., Matzdorf, F., Smith, L., \& Agahi, H. (2003). The impact of facilities on student choice of university. Facilities, 21(10), 212-222.

Purkayastha, B. (2005). Skilled migration and cumulative disadvantage: the case of highly qualified Asian Indian immigrant women in the US. Geoforum, 36(2), 181-196.

QS Quacquarelli Symonds Ltd. (2009). Times Higher Education-QS World University Rankings 2009: Top 200 world universities. Retrieved 23 August, 2010, from http://www.timeshighereducation.co.uk/Rankings2009-Top200.html

Qureshi, S. (1995). College accession research: New variables in an old equation. Journal of Professional Services Marketing, 12(2), 163-170.

Radu, D. (2008). Social interactions in economic models of migration: a review and appraisal. JOURNAL OF ETHNIC AND MIGRATION STUDIES, 34(4), 53-148.

ROA. (2005). De arbeidsmarkt naar opleiding en beroep tot 2010 (Vol. November 2005). Maastricht: Faculty of Economic Sciences and Business Management, University of Maastricht.

Robinson, V., \& Carey, M. (2000). Peopling Skilled International Migration: Indian Doctors in the UK. International Migration, 38(1), 89-108.

Roodenburg, H. (2000). Immigratie in Nederland: economische gevolgen. In N. v. Nimwegen \& G. Beets (Eds.), Bevolkingsvraagstukken in Nederland anno 2000 (Vol. NiDi-rapport no. 58). The Hague: NiDi.

Roodenburg, H., Euwals, R., \& Rele, H. t. (2003). Immigration and the Dutch Economy: Facts and Figures. The Hague: Netherlands Bureau for Economic Policy Analysis.

Rosenzweig, M. (2006). Higher Education and International Migration in Asia: Brain Circulation. Paper presented at the Regional Bank Conference on Development Economics: Higher Education and Development, Beijing.

Rothgang, M., \& Schmidt, C. M. (2003). The New Economy, The Impact of Immigration, and the Brain Drain. In D. C. Jones (Ed.), New Economy Handbook. Amsterdam, New York and Tokyo: Elsevier Science.

Ruiz, N. G., \& Wilson, J. H. (2013). The 2014 H-1B Visa Race Begins Today Retrieved 12 February 2014, from http://www.brookings.edu/blogs/upfront/posts/2013/04/01-2014-h1b-visas-ruiz-wilson

Salmi, J. (2009). The Challenge of Establishing World-Class Universities. Washington DC: The International Bank for Reconstruction and Development/World Bank. 
Salt, J. (1997). International Movements of the Highly Skilled. Paris: OECD.

Sassen, S. (1998). The de facto trnasnationalizing of immigration policy. In C. Joppke (Ed.), Challenge to the nation-state: Immigration in Western Europe and the United States (pp. 49-85). Oxford: Oxford University Press.

Schiff, M. (2005). Brain gain: claims about its size and impact on welfare and growth are greatly exaggerated. Washington, D.C.: World Bank, Development Research Group, Trade Team.

Sciortino, G. (2000). Toward a political sociology of entry policies: Conceptual problems and theoretical proposals. JOURNAL OF ETHNIC AND MIGRATION STUDIES, 26(2), 213-228.

Shachar, A. (2006). The Race for Talent: Highly Skilled Migrants and Competitive Immigration Regimes. New York Law Review, 81, 148-206.

Shaftel, J., Shaftel, T., \& Ahluwalia, R. (2007). International Educational Experience and Intercultural Competence. International Journal of Business \& Economics, 6(1), 25-34.

Singhvi, L. M., et al. . (2001). Report of the High Level Committee on Indian Diaspora. New Delhi: Government of India, Ministry of External Affairs.

Sjaastad, L. A. (1962). The Costs and Returns of Human Migration. The Journal of Political Economy, 70(5), 80-93.

Skeldon, R. (2005). Globalization, skilled migration and poverty alleviation brain drains in context. Brighton: University of Sussex, Development Research Centre on Migration, Globalisation and Poverty.

Smith, D. P. (2004). An 'untied' research agenda for family migration: loosening the 'shackles' of the past. JOURNAL OF ETHNIC AND MIGRATION STUDIES, 30(2), 263-282.

Social Economic Council. (2007). Advies: Arbeidsmigratie belied Publication (Vol. 2). The Hague: Social Economic Council

Soutar, G. N., \& Turner, J. P. (2002). Students' preferences for university: a conjoint analysis. The International Journal of Educational Management, 16(1), 4045.

Srikatanyoo, N., \& Gnoth, J. (2002). Country image and international tertiary education. Journal of Brand Management, 10(2), 139-146.

Stalker, P. (2000). Workers Without Frontiers: The Impact of Globalization on International Migration. Boulder, Colorado; Geneva: Lynne Rienner Publishers; ILO.

Stark, O. (1991). The Migration of Labor. Cambridge: Basil Blackwell.

Stark, O., \& Bloom, D. (1985). The New Economics of Labor Migration. American Economic Review, 75(2), 173-178.

Stark, O., Helmenstein, C., \& Prskawetz, A. (1998). Human capital depletion, human capital formation and migration: a blessing in a "curse"? Economic Letters, 60(3), 363-367.

Stark, O., \& Wang, Y. Q. (2002). Migration Dynamics. Economics Letters, 76.

Straubhaar, T. (2000). International mobility of the highly skilled: brain gain, brain drain or brain exchange. HWWA Discussion Paper, 88. 
Tacsir, E. (2010). Occupation choice: Family, Social and Market influences. UNUMerit Working Paper Series, 14.

Thielemann, E. (2004). Does Policy Matter? On Governments' Attempts to Control Unwanted Migration. CCIS Working Paper, University of California, San Diego, 112.

Tilly, C. (1990). Transplanted networks. In V. Yans-MacLoughlin (Ed.), Immigration Reconsidered (pp. 79-95.). New York: Oxford University Press.

Tinnemans, W. (1994). Een gouden armband: een geschiedenis van mediterrane immigranten in Nederland (1945-1994). Utrecht: Nederlands Centrum Buitenlanders.

Todaro, M. P. (1969). A model of labor migration and urban unemployment in less developed countries. American Economic Review, 59, 138-148.

Todisco, E. (1993). Intellectual, professional and skilled migrations,. Studi Emigrazione, 112(574-90).

Todisco, E., Brandi, M. C., \& Tattolo, G. (2003). Skilled Migration: a theoretical framework and the case of foreign researchers in Italy. Fulgor, 1(3), 115130.

Tremblay, K. (2002). Student Mobility Between and Towards OECD Countries in 2001: A Comparative Analysis. In OECD (Ed.), International Mobility of the Highly Skilled (pp. 39-67). Paris: OECD.

U.S. Department of State. (2009). Employment-Based Visas. http://travel.state.gov/visa/immigrants/types/types_1323.html

UGC. (2006). Annual Report 2005-2006. In U. G. Commission (Ed.). New Delhi, India: University Grants Commission.

UNESCO-IUS. (2009). Table 8: Tertiary education/ enrollment, graduating ratio and teaching staff Global Education Digest 2009: Comparing Education Statistics around the World (pp. 135). Montreal, Canada: UNESCO-IUS.

UNESCO-IUS. (2010a). Global Education Digest 2010: Comparing Education Statistics Across the World. Montreal: Canada.

UNESCO-IUS. (2010b). Table 10: Internaitonal flows of mobile students 2008 Global Education Digest 2009: Comparing Education Statistics around the World (pp. 176-181). Montreal, Canada: UNESCO-IUS.

USCIS. (2009). $2010 \quad \mathrm{H}-1 \mathrm{~B} \quad$ Petition Season. http://www.uscis.gov/portal/site/uscis/menuitem.eb1d4c2a3e5b9ac892 43c6a7543f6d1a/?vgnextoid=e7d696cfcd6ff110VgnVCM1000004718190 aRCRD\&vgnextchannel=e7d696cfcd6ff110VgnVCM1000004718190aRCR D

USCIS. (2010). Characteristics of H-1B Specialty Occupation Workers: Fiscal Year 2009 Annual Report. Washington DC: US Department of Homeland Security.

USDHS. (2011). Yearbook of Immigration Statistics: 2010 Yearbook of immigration statistics. Washington, D.C.: U.S. Department of Homeland Security, Office of Immigration Statistics. 
USDHS. (2012). Yearbook of Immigration Statistics 2011. Washington DC: U.S. Department of Homeland Security, Office of Immigration Statistics.

Van Dalen, H. P., Groenewold, G., \& Fokkema, T. (2005). The Effect on Remittances on Emigration Intentions in Egypt, Morocco, and Turkey. Population Studies, 59(3), 375-392.

Van Dalen, H. P., Groenewold, G., \& Schoorl, J. J. (2005). Out of Africa: What Drives the Pressure to Emigrate? Journal of Population Economics, 18(4), 741778.

Van Dalen, H. P., \& Henkens, K. (2008). Emigration Intentions: Mere Words or True Plans? Explaining International Migration Intentions and Behavior. Discussion Paper. CentER, University of Tilburg.

van der Velde, M., \& van Naerssen, T. (2007). People, borders and trajectories. A model to approach migration in the enlarged European Union In T. van Naerssen \& M. v. d. Velde (Eds.), Migration in a New Europe: People, Borders and Trajectories (pp. 145-154). Rome: International Geographical Union / Societa Geographica Italiana

Van Dijk, P. J. C., \& Penninx, R. (1976). Migration and development: The Netherland's Remplod project: an experimental venture in the integration of research in the field and policy making. The Hague: INWOO/NUFFIC.

Vincent-Lancrin, S. (2008). Student mobility, internationalization of higher education and skilled migration. In G. Appave \& R. Cholewinski (Eds.), World Migration 2008 (pp. 105-123). Geneva: IOM.

Vogler, M., \& Rotte, R. (2000). The Effects of Development on Migration: Theoretical Issues and New Empirical Evidence. Journal of Populaiton Economics, 13, 485-508.

Wadhwa, V. (2012). The Immigrant Exodus: Why America Is Losing the Global Race to Capture Entrepreneurial Talent. Philadelphia: Wharton Digital Press.

Wadhwa, V., Saxenian, A., Freeman, R., \& Salkever, A. (2009). Losing the World's Best and Brightest: America's New Immigrant Entrepreneurs, Part $\mathrm{V}$ Research Report. Kansas City, MO: Ewing Marion Kauffman Foundation.

Wallerstein, I. (1974). The Modern World System. Capitalist agriculture and the European World economy in the sixteenth century. New-York; San Francisco; London: Academic Press.

Wickham, J. (2008). A skilled migration policy for Europe? Issues and problems. . Paper presented at the European Governance of Migration, Heinrich Böll Stiftung, Berlin.

Wiers-Jenssen, J. (2008). Does higher Education Attained Abroad Lead to International Jobs? Journal of Studies in International Education, 12(2), 101-130.

Wiesbrock, A. (2010). Legal migration to the European Union. Leiden; Boston: Martinus Nijhoff Publishers.

Wiesbrock, A., \& Hercog, M. (2010). The Legal Framework For Highly-Skilled Migration To the EU: EU And US Labour Migration Policies Compared. MGSoG Working Paper(1). 
Wiggins-Frame, M., \& Shehan, C. L. (1994). Work and Well-Being in the TwoPerson Career: Relocation Stress and Coping among Clergy Husbands and Wives. Family Relations, 43(2), 196-205.

Wright, R. E., \& Maxim, P. S. (1993). Immigration policy and immigrant quality: Empirical Evidence from Canada. Journal of Population Economics, 6(4), 335-352.

WRR. (1979). Etnische minderheden. Den Haag: SDU.

Xia, N. (2010). Family factors and student outcomes (Vol. Pardee RAND Graduate School Series). Santa Monica, California: RAND Corporation.

Zaletel, P. (2006). Competing for the Highly Skilled Migrants: Implications for the EU Common Approach on Temporary Economic Migration. European Law Journal, 12(5), 613-635.

Zimmermann, K. F. (2009). Labor Mobility and the Integration of European Labor Markets. IZA Discussion Paper, 3999.

Zimmermann, K. F., Bonin, H., Fahr, R., \& Hinte, H. (2007). Immigration Policy and the Labor Market: The German Experience and Lessons for Europe. Berlin: Springer Verlag. 


\section{Nederlandse Samenvatting}

\section{Hoogopgeleide migranten en nieuwe bestemmingslanden}

In competitie voor hoogopgeleide arbeid veranderen veel geïndustrialiseerde landen hun beleid, om aantrekkelijker te worden voor hoogopgeleide migranten. De "traditionele immigratie landen" (Australië, Canada en de Verenigde Staten) bieden al langere tijd flexibele toelatingscriteria en aantrekkelijke verblijfscondities aan hoogopgeleide migranten, in tegenstelling tot Europese landen. Deze waren terughoudend hun "geen migratie beleid", dat aangenomen was na de olie crisis van 1973, op te geven. Echter, ook Europese landen zijn steeds meer bezig hun arbeidsmigratie beleid aan te passen, om geschoolde arbeidskrachten uit andere landen aan te trekken. Er is voor deze Europese landen (specifiek Groot Brittannië, Nederland en Duitsland) gekozen als geografische focus van dit proefschrift vanwege de status van deze Europese landen als relatief nieuwe speler zijn op de markt van kennismigranten.

Het is het van belang te realiseren dat sommige landen, met uitzondering van het Verenigde Koninkrijk, sinds de start van de Europese financiële crisis in 2007, hun beleid om immigratie te liberaliseren een halt hebben toegeroepen, terwijl andere landen nadrukkelijk wel het pad richting progressief aantrekkelijkere voorwaarden voor toelating van buitenlandse kennismigranten hebben doorgezet. Deze trend is waarschijnlijk blijvend, en een saillant kenmerk in het immigratiebeleid, gegeven het feit dat de problemen van internationale competitie en het verouderen van de maatschappij zullen aanhouden op de lange termijn. Dit proefschrift illustreert de algemene erkenning, dat het kunnen beheren van de arbeidsstromen, met name het aantrekken van wenselijke immigratie en het ontmoedigen van ongewenste immigratie, een belangrijke component is binnen de economische strategieën van de landen die bestudeerd zijn. Het is echter nog steeds onduidelijk in hoeverre deze erkenning, die zich vertaald heeft in meer open migratiebeleid, heeft geleid tot het daadwerkelijk beter presteren van Europese landen in het aantrekken van hoogopgeleide migranten, gegeven de wereldwijde competitie.

Aangezien potentiële migranten kijken naar het beste land om in te wonen, zullen ze geïnteresseerd zijn in de sociaaleconomische en politieke factoren in de landen van bestemming waarin ze kunnen werken; factoren die aantrekkelijk of onaantrekkelijk zijn voor een bepaalde keuze. Concurrerende overheden kunnen de meeste factoren enkel indirect controleren. Immigratie beleid heeft echter als direct doel het aantrekken of ontmoedigen van bepaalde typen van migranten, en kan worden aangepast als het beleid bij nader inzien ongeschikt wordt bevonden. 
Immigratiebeleid is de eenvoudigste directe manier voor overheden om migratiestromen te beïnvloeden.

$\mathrm{Er}$ is een redelijk overzichtelijke stroom onderzoek naar de determinanten van migratie op macro niveau. Dit proefschrift beoogt het gat in de kennis te dichten, dat bestaat over de rol die het nationale migratie beleid en de landspecifieke factoren in positieve of negatieve zin spelen bij de keuze van individuen op microniveau om internationaal te migreren. De studie kijkt naar de effecten van overheidsbeleid op de keuze van een bestemmingsland voor hoog- opgeleide migranten, in gedachte houdend dat de landenkeuze van hoogopgeleide migranten meer bewust zal zijn dan de keuze van laagopgeleide migranten. Ook neemt de studie mee dat beslissingsfactoren van hoogopgeleide migranten verschillend kunnen zijn van de factoren van laagopgeleide migranten, en dat de factoren verschillend kunnen zijn van de factoren die van belang bevonden zijn bij andere vormen van migratie. De rol van de staat betreft het aantrekken van potentiële migranten, en de overwegingen van de migranten spelen dus een grote rol.

Twee verschillende aanpakken zijn in dit onderzoek gebruikt, en dat is te zien in de opzet van het proefschrift. Het eerste deel van de dissertatie gebruikt kwalitatieve data zoals wettelijke documenten, overheidspublicaties en academische literatuur om de determinanten van migratie en specifiek de rol van migratiebeleid binnen dit proces te bestuderen. De theoretische analyse bekijkt de vraag-en aanbodsfactoren om locatie specifieke dynamieken van hoogopgeleide migratie uit te leggen. De studie wijst naar de niet lineaire relatie tussen immigratiebeleid en migratiekeuzes. Verder worden de elementen binnen overheidsbeleid zelf bestudeerd vanuit het perspectief van stimuleren en ontmoedigen van migratie, waarbij een overzicht van alle elementen van beleid die de bestemmingskeuze kunnen beïnvloeden aan bod komen. Het tweede deel van de dissertatie is een empirische casestudie van potentiële Indiase migranten. Een kwantitatieve vragenlijst en diepte-interviews worden gebruikt om de aandrijvers van internationale studenten mobiliteit te begrijpen, alsook te leren hoe potentiële toekomstige migranten denken over hun bestemmingsmogelijkheden. Beide delen samen helpen het potentieel van Europese landen te bevatten als actoren in het hoger opgeleide migratieveld.

De analytische aanpak, die een aantal theorieën die relevant zijn voor het bepalen van migratiestromen combineert, is aangepast aan de overwegingen van hoogopgeleide migranten die worden geacht specifieke zaken zoals cultuur en financiële stimulans te waarderen. Het hoofdstuk toont aan dat de staat kan interveniëren in migratie management op een aantal manieren, zowel economisch als sociaal en cultureel. Dit betekent dat de staat ook kan ingrijpen op manieren anders dan enkel via direct migratie beleid (Hoofdstuk 2). 
Een systematische vergelijking tussen drie Europese landen (Groot Brittannië, Nederland en Duitsland) en hun belangrijkste concurrent (de Verenigde Staten) in termen van het bestaande wettelijk systeem m.b.t. arbeidsmigratie geeft aan dat de Verenigde Staten niet langer het specifieke positieve voorbeeld zijn. De vergelijking is uitgevoerd door naar vijf verschillende aspecten van beleid te kijken, waarbij de aantrekkelijkheid van de EU en de nationale regels die gelden voor potentiële hoogopgeleide migranten worden geanalyseerd op gebied van a) toelatingscriteria, b) speciale regelingen voor jonge migranten en mogelijkheden voor voormalige studenten, c) geldigheid van verblijfsvergunningen en toegang tot permanente verblijfsvergunningen, d) familie migratie mogelijkheden, en e) werknemersrechten en sociale voorzieningen. Op bepaalde aspecten van migratiebeleid worden de bestudeerde Europese landen beoordeeld als op zijn minst even attractief voor kennismigranten als de Verenigde Staten. De grootste bestaande obstakels om EU lidstaten om te vormen tot aantrekkelijke bestemmingslanden voor hoogopgeleide migranten zijn ten eerste de publieke perceptie van de EU als zijnde "Fort Europa" en ten tweede de fragmentatie van de Europese arbeidsmarkt en het gebrek aan rechten voor vrij vervoer voor mensen uit derden landen (Hoofdstuk 3)

Nederland geldt als voorbeeld voor een open kenniseconomie met een ouder wordende bevolking die een proactieve aanpak verkiest om arbeid aan te trekken met de noodzakelijke vaardigheden vanuit het buitenland, om de tekorten in arbeidsaanbod in specifieke kennisgebieden te verminderen. De huidige situatie, met een relatief klein aandeel van buitenlandse hoogopgeleide arbeiders in Nederland stamt af van de tijd van de kolonisatie en de arbeidmigratie eind jaren 1960 en begin 1970, gevolgd door familie migratie. Na een periode waarin een bewust strakke wettelijk situatie bestond om de familie migratie te beperken, is arbeidsmigratie op dit moment weer de meest prominente vorm van migratie. Echter, veel van de recente stijging in immigratie valt terug te leiden naar migratie van binnen de EU. Het kennismigranten schema, dat de noodzaak voor niet-EU hoogopgeleide migranten goed weergeeft, vereenvoudigt toegang voor migranten uit niet-traditionele migratielanden. Indiase migranten, jong, voornamelijk werkend in de technologiesector en typisch in Nederland verblijvend voor kortere perioden, zijn een voorbeeld voor de categorie migranten die Nederland wenst aan te trekken (Hoofdstuk 4).

Het tweede deel van de dissertatie zoemt in op de regio waar vanuit de migranten komen, en presenteert een case studie over potentiële migranten in India. Slechts een paar jaar geleden was het overgrote deel van de opgeleide migranten uit India enkel geïnteresseerd in migratie naar de Verenigde Staten, maar vandaag de dag zijn de Indiërs geïnteresseerd in een keuze uit een gevarieerder aantal landen. Onder andere Europa komt op als bestemmingsregio. Dit is een betrekkelijk nieuw 
fenomeen, wat begonnen is in de 1990s en 2000s. Sommige landen hebben duidelijke voordelen in het aantrekken van hoogopgeleide Indische arbeidskrachten, met name die landen waar Engels gesproken wordt of die landen met een koloniaal verleden met India. Vastenland Europa heeft een achtergestelde positie, vanwege verschillende factoren: de taal, die meestal enkel gesproken wordt door een kleine groep mensen buiten het gastland, beperkte historische banden van deze landen met India, een korte en beperkte geschiedenis van aantrekken van opgeleide migranten en tenslotte een klein netwerk van Indiërs die al in de samenleving wonen en die relevante informatie over het gastland aan mensen in India kunnen doorgeven. Al deze factoren werken niet positief voor Indiërs die vastenland Europa als hun belangrijkste bestemming beschouwen voor werk of studie (Hoofdstuk 5).

Dit proefschrift bestudeert de case van potentiële Indische migranten. De studie analyseert ten eerste hun keuze om naar het buitenland te migreren en ten tweede de factoren die het gastland van keuze bepalen. Professionele aspecten, gerelateerd aan het werk en vervolgopleidingen zijn aangetoond het meest prominent in de migratie beslissing. Plannen om je voor langere periodes in het buitenland te vestigen zijn schaars, en dit beïnvloedt de factoren die van belang zijn bij de keuze van bestemming. In de situatie dat mensen enkel een korte tijd in het buitenland verwachten te zijn, zijn sociale zekerheid en sociale diensten minder belangrijk in het keuzeproces. Tevens is een aantrekkelijke omgeving van secundair belang in de keuze, als het een korte periode van verblijf betreft. Het hechten van grote waarde aan familie en vrienden is een goede indicator voor het blijven van studenten in hun thuisland India, en dus überhaupt niet migreren. Gebrek aan financiering om naar het buitenland te gaan, en gebrek aan steun vanuit de familie zijn de grootste barrières om te migreren (hoofdstuk 6).

Om aantrekkelijk te zijn, moeten gastlanden actief de gewenste individuen aantrekken, en om die reden is het van belang te begrijpen waarop deze individuen het beste reageren. Het imago van een land is van belang in de migratie keuze, en heeft een grotere invloed op de keuze van gastland dan de status van een universiteit en reputatie van universitaire programmes. De belangrijkste voorspellers van een landenvoorkeur zijn de studierichting van de student in India, het niveau van het onderwijsprogramma in India, de steun van ouders, het netwerk van vrienden in het buitenland, het motief te migreren, kennis van de Engelse taal en de locatie van de woonplaats binnen India. Vastenland Europa is een nieuw bestemmingsgebied dat studenten overwegen voor ze migreren, maar dit gebied bevat nieuwe risico's. Om deze risico's te overwinnen en Europa toch als bestemming te kiezen, zijn meer materiële middelen en grotere vaardigheden nodig. Dit kan middels het hebben van al aanwezige netwerken in het buitenland, een hoger opleidingsniveau, of betere kennis van de taal. Hoewel Europese landen 
worden beschouwd als relatief aantrekkelijke landen om in te studeren worden ze niet gezien als even aantrekkelijk om langere tijd in te verblijven (Hoofdstuk 7).

De case van India bekijkend, als een van de meest belangrijke emigratie landen, zien we dat de keuze om naar het buitenland te gaan bijna gelijk is aan de keuze om naar de Verenigde Staten te gaan. Het blijft het meest belangrijke land voor studie en biedt de meeste carrière mogelijkheden. Europese regeringen doen veel moeite om studentenmigratie te integreren in een bredere immigratiestrategie. Deze strategie lijkt niet effectief zo lang mogelijke migranten duidelijk Europese landen niet zien als mogelijk gastland voor werkende mensen na afstuderen. Het beeld van Europa als enkel aantrekkelijk voor korte termijnen migratie is een weerspiegeling van Europa's aandacht voor tijdelijkheid van immigratie en de beperkingen van lange termijn migratie, specifiek voor laagopgeleide mensen. In de situatie dat de migratie naar het buitenland voor een korte termijn project is, ongeacht of dit studie of werk gerelateerd is, zijn veel verschillende vormen van beleid dat kennismigranten moet aantrekken minder relevant. Tenslotte is het bij de keuze om naar het buitenland te gaan duidelijk dat professionele redenen en economische factoren van groter belang zijn dan institutionele en sociaal politieke factoren. Fragmentatie van de Europese arbeidsmarkt en het gebrek aan vrij vervoer tussen landen voor mensen van derden nationaliteit dat daarmee geassocieerd wordt, blijven een van de meest serieuze uitdagingen om de EU lidstaten om te vormen in aantrekkelijke bestemmingslanden. 


\section{Addendum on valorization to the dissertation}

This dissertation looks into the effect of government policies on the choice of a destination country for highly-skilled migrants. While selective migration policies are often mentioned as a reason for increasingly skilled migration, there has not been much empirical research in this field. Exploring the link between immigration policies and determinants for migration on an interesting case of a recently introduced policies in continental European countries and concurrent increase in immigration of skilled Indians has relevant implications for aspiring entrants in the international competition for talent. That highly-qualified migrants can boost the contributions to innovation to keep Europe from progressively loosing markets for its products and services, is clearly stated in the European policy documents and a commonly-shared opinion among experts in the field. The European Union sees labour migration between European Union countries as the main approach to respond to the challenges of labour market shortages, but even with the downturn of the European economies the need for non-EU skilled labour remains a salient feature of European economies. As the internal mobility within the European Union remains low, immigration from outside the European Union signifies an obvious solution as it is already larger than cross-border migration within the EU. However, immigration to the EU is predominantly low-skilled, especially when compared with the skills composition of immigrants to the traditional immigration countries. The growing concern with national competitiveness and aging societies has led many of them to redesign their policies into targeted migration programmes aiming to select specific types of migrants. There is a risk involved that policy-makers make assumptions on what migrants consider as a pole of attraction. This study, therefore, contributes to the knowledge on migrants' considerations which are relevant for possible policy interventions that would function as incentives to immigrate to a certain country.

A number of factors influence the decision to choose a specific place of migration. It can be career-related factors, personal circumstances, existence of prior links with the country, preferences for local environment, or institutional factors, such as an option of obtaining host country's citizenship. With an overview of theories with relevance for determining international flows of highy-skilled migrants, this dissertation shows that the state can intervene in migration management in a number of ways, either economic, social or cultural, and that several of the mentioned ways point to state intervention beyond tailoring migration policies. The expectation of a migrant to see a potential host country as an attractive destination can be boosted by recruitment agencies, advertising and efficient application procedures. Positive signals can be sent out by giving opportunities for foreigners 
to access good positions in the labour market. Providing prospects for professional development is an important aspect for career-oriented people that decide to move for job related reasons. Also, the possibility to settle in a country and reap the investment related to migration for a longer period of time is a factor in destination choice. When host governments design skills-targeted immigration policies, they have certain assumptions in mind what would exert a pull on skilled workers. The design of policy reflects as well what kind of people are wanted in the host country. They use very different eligibility requirements as for who constitutes a highly-skilled migrant. It can depend on qualifications and experiences of potential migrants or solely on a type of job offer. Assuming that a country has a clear objective as for what type of migrants it wants to attract, it should also think of designing its policy in a way that it addresses the concerns of the targeted group. While offering migrants' access to social security benefits seems as an important attribute of an attractive immigration policy from a perspective of European policymakers, potential migrants in India, on the contrary, do not pay much attention to it or even have a negative opinion about it. It is notable to observe that in terms of immigration policies, the possibility of permanent settlement and acquisition of citizenships are not considered important for their choice of location. Especially for students who choose Europe as a destination area, the possibility of settlement is particularly not important. This shows the motivation to continental European countries to be limited for the purpose of higher education, reducing the relevance students place on admission procedures. While European countries appear to be relatively attractive for study purposes, they are not perceived equally attractive as a place for a long-term stay. With less long-term migration initiatives to Europe, immigration policies and destination country-specific factors, chances to obtain citizenship and amenities of local environment turn out to be less relevant. All these findings point to the problem that continental European countries face for retaining foreign students. The results show that career prospects matter most to attract the highly-skilled, which provides clear policy implications. Improving the access to the labour market for foreign workers and transition from studying to the local labour market would cover the missing link in placing continental Europe more visibly on the map of global race for talent.

Country image and public perception does not work in favour of European attractiveness. It is safe to assert that the restrictionist discourse Europe leads towards migration as a whole has unintended consequences also for the category of migrants which is not planned to be targeted by this message. European governments place considerable effort on integration of student migration as a part of a wider immigration strategy. International students are valued not only for their contributions to creating an international context in higher education but also for having a potential role in meeting research agendas and labour market needs in host countries. This strategy is likely to prove ineffective if European countries are 
not seen as prospective work destination for the period after their graduation. It is more likely to happen that after they finish their education in Europe, they will move on to a third country, most likely the United States. The perception of Europe as only an attractive short-term migration destination is a reflection of Europe's stress on temporariness of immigration and limitations for long-term migration, especially for the low-skilled. At the same time, this focus reduces the relevance of several elements in the immigration policies which were included with the objective to increase attractiveness for high-skilled migrants for longer periods. In the situation when the motivation for moving abroad is exclusively limited to completion of a short-term project, be it study or work, many of the favourable options introduced in the recent versions of immigration policies to attract highly skilled migrants do not matter to a large extent. Access to social security and benefits, admission criteria as well as factors related to social contacts are not placed on par in importance with comparison with career path considerations. The decision to go abroad is guided by professional motives and economic factors override institutional and socio-political factors in migration decisions. In addition to changing immigration policies, European countries have to change the perception of career possibilities, which can best be done with real examples of successful immigrant stories. Likewise, the direct branding and marketing of Europe as attractive long-term destination for (Indian) highly-skilled migrants should be increased. Significant potential for improving the recognized obstacles of the European countries lies in addressing the problem of fragmented European labour market, which unfortunately failed to be solved by the Blue Card Directive. Besides addressing the size of the labour market with further reforms, several other factors which contribute to the disadvantaged position of continental European countries need to be addressed. Governments can certainly shape the institutions and processes that provide the link between potential migrants and employers. By fostering exchange between countries social networks can be created which could counteract the limited historical ties with several important sending countries of skilled labour.

These research results are of interest for governments of countries which have the objective to attract highly-skilled workers and are directly relevant to continental European countries, which have made significant efforts to facilitate the entry for migrants from non-traditional sending countries, such as India. Counter to the general public perception, which sees Europe as "Fortress Europe" and the United States as an immigrant-friendly country, the observed EU Member States are found to be at least as attractive for highly-skilled immigrants in terms of immigration policies. In particular, Germany and the Netherlands have taken some valuable practical measures to open up their job markets to skilled workers from third countries. Examples of such are the Federal Law on Recognition of Foreign Qualifications in Germany which allows for reviewing foreign qualifications relative 
to German equivalents or the introduction of a short residence as knowledge migrants in the Netherlands. While the United Kingdom tightened eligibility rules in 2011, these two countries are going in the opposite direction. The Netherlands stands out in comparison with other countries in its favouring of young professionals, who still face obstacles for immigration in income threshold in Germany. Both countries have, however, introduced measures for easier transition from studies to the job market by allowing for job-searching periods after graduation, which is no longer an option in the United Kingdom. Likewise, new legal routes for third-country nationals enable residence in Germany and the Netherlands even without a prior job offer. This research shows that the potential migrants simply do not know how attractive Europe is in their specific case. If, for any kind of reason, a certain country needs foreign workers and a government in question takes this issue as a serious matter, then it should act accordingly and become active in welcoming foreigners in all respects. Merely removing barriers is, by definition, not sufficient if a country wants to be a pole of attraction for the most skilled labour force. As a pole of attraction, a destination country has to actively pull the desired individuals and for that purpose, it is necessary to comprehend to what these individuals respond best.

That policies of European countries cannot be considered entirely effective could be due to the possible delay before the intended message of the policy reaches the target audience, so the mentioned publications work also as a measure to inform prospective immigrants of their objective conditions in different countries. We find that information available to students about potential destinations is limited, making the decision dependent on the available information and existing perceptions about which options are best for them. The decision is based on a limited number of better known choices, picking their preferred destination out of a few options. For that reason, the author considers prospective migrants also as a target population, to which results of this study should be of interest.

Several publications, available to general public, came out of research relevant to this disseration. Ms. Hercog contributed to an output of the EC-funded World Bank program of International Migration from the Middle East and North Africa and Poverty Reduction Strategies with the study on changes in immigration in the Netherlands. Secondly, she wrote a piece in the Bulletin of the European Institute of Public Administration, called Eipascope, which aims to increase public awareness of current European issues. The contribution on the role of the state in attracting highly-skilled migrants, again discussing the case of The Netherlands, is of a general character and accessible to the general public. The objective of the bulletin is to present, discuss and analyse policy and institutional developments, legal issues and administrative questions that shape the process of European integration. She also participated at the Transatlantic Strategy Forum on 'The European Union, United 
States and Global Governance - Major Trends and Challenges", with the purpose to contribute to the construction of a shared transatlantic vision of the strategic challenges facing the EU and the US. Together with Dr. Anja Wiesbrock she examined the existing legal framework on highly-skilled migration in the United Kingdom, Germany and the Netherlands, and compared it with that of the US. Contrary to general public perception, we pointed out that in terms of policy the EU Member States are at least as 'attractive' for highly-skilled migrants as the US. The paper was selected for the publication by Leuven Center for Global Governance Studies with the title "European Union, United States and Global Governance Major Trends and Challenges". Dr. Wiesbrock and Ms. Hercog made a more detailed analysis of attractiveness for immigrants from India for the case of the the Netherlands and Germany and published it as a research report of the CARIM-India project. This project was conducted, among others, in collaboration with the Indian Council of Overseas Employment and aims at consolidating a constructive dialogue between the EU and India on topics of migration.

Besides discussing results of this research at several academic conferences, the author of this dissertation also contributed to public debates on the contentious topic of migration. One such event was an introduction to a film festival, organized by Maastricht University Centre for International Cooperation in Academic Development (MUNDO). During the period of writing the dissertation, Ms. Hercog also managed the development of a Master programme in European Migration Policies, a joint collaboration between Maastricht University and the European Institute of Public Administration (EIPA). The product of that engagement is now the Master specialization in migration studies at the Maastricht Graduate School of Governance. Together with Prof. Joan Muysken, Dr. Katerina Kyrieri and Dr. Pascal Beckers she participated in developing training modules for public officials working in the field of migration and integration in Europe. When highly-skilled emigration became a concern in her native country Slovenia, she discussed this with a journalist from a weekly newspaper Mladina. The interview was published in 2012 in the edition with 18.000 sold copies. The main topic was the recent increase in European youth unemployment and related migration flows, and how affected countries like Slovenia should respond. Countries which before the crisis received many immigrants are now turning into major sending countries. High unemployment and related emigration continue to shrink these countries' labour force, particularly among youth. The author finds it important to stress the role of governments in migration flows and also that outflows of skilled people do not necessarily lead to negative outcomes. 


\section{Short biography}

Metka Hercog obtained a University Degree in Political Science with specialistion in International Affairs from the University of Ljubljana and an MSc degree in International Development Studies from Utrecht University. On the basis of fourmonth internship with the Netherlands' Development Organization in Tanzania, she wrote her Master thesis on managing natural resource scarcity. Prior to joining the PhD programme at the University of Maastricht, she worked at the Center of Excellence in Finance (CEF) in Ljubljana. Since 2006, she has focused her research on migration and development. Over the course of her doctoral research the Maastricht Graduate School of Governance, Ms. Hercog presented her work at numerous research workshops and international conferences. She was a Visiting Research Fellow at the Institute for the Study of International Migration (ISIM) at Georgetown University in Washington, DC (2010) and has conducted extensive fieldwork in several locations in India in conjunction with Jawaharlal Nehru University (JNU), New Delhi. Between 2011 and 2013, she held a position of scientific collaborator at the Cooperation and Development Center at the Ecole Polytechnique Fédérale de Lausanne (EPFL), where she was the principal investigator on a research project examining skilled Indian migration and development. She also worked at the University of Lausanne as the country coordination for Switzerland on the project "Mapping the Population, Careers, Mobilities and Impacts of Advanced Research Degree Graduate Studies in the Social Sciences and Humanities". At her most recent job as a programme officer at the Labour Migration Branch of International Labour Organization (ILO), Ms. Hercog worked on testing possible methodologies to produce a global estimate on migrant domestic workers and on developing a standard methodology for assessing outcomes for migrant workers within bilateral migrant schemes. 


\section{MGSoG Dissertation Series}

Margaret Rugadya

Can remittances influence the tenure and quality of housing in Uganda?

MGSoG Dissertation Series, nr 40 (2014)

Ilire Agimi

New Governance under Limited Statehood: The Case of Local Government Reform in Kosovo,

MGSoG Dissertation Series, nr 39 (2014)

Marina Petrović

Social assistance and activation in the pursuit of happiness: shedding new light on old policy solutions to social exclusion,

MGSoG Dissertation Series, nr 38 (2013)

Kristine Farla

Empirical studies on institutions, policies and economic development, MGSoG Dissertation Series, nr 37 (2013)

Laura Torvinen

Assessing Governance Assessments; the Case of Mozambique Governance Assessments in the Context of Aid Effectiveness Discourse

MGSoG Dissertation Series, nr 36 (2013)

Biniam Egu Bedasso

Institutional Change in the Long Shadow of Elites: Essays on Institutions, Human Capital and Ethnicity in Developing Countries

MGSoG Dissertation Series, nr 35 (2013)

Sepideh Yousefzadeh Faal Deghati

Childhoods Embargoed: Constructing and Reconstructing Multidimensional Child Poverty in Iran 1984-2009

MGSoG Dissertation Series, nr 34 (2013)

Robert Bauchmüller

Investing in Early Childhood Care and Education: The Impact of Quality on Inequality

MGSoG Dissertation Series, nr 33 (2013) 
Martin Rehm

Unified yet Separated

Empirical Study on the Impact of Hierarchical Positions within Communities of Learning

MGSoG Dissertation Series, nr 32 (2013)

Dorcas Mbuvi

Utility Reforms and Performance of the Urban Water Sector in Africa

MGSoG Dissertation Series, nr 31 (2012)

Lina Salanauskaite

Distributional Impacts of Public Policies: Essays in Ex-Ante and Ex-Post Evaluation MGSoG Dissertation Series, nr 30 (2012)

Esther Schüring

To Condition or not - is that the Question? An Analysis of the Effectiveness of ExAnte and Ex-Post Conditionality in Social Cash Transfer Programs

MGSoG Dissertation Series, nr 29 (2012)

Joe Abah

Strong Organisations in Weak States: Atypical Public Sector Performance in Dysfunctional Environments

MGSoG Dissertation Series, nr 28 (2012)

Zina Samih Nimeh

Social Citizenship Rights: Inequality and Exclusion

MGSoG Dissertation Series, nr 27 (2012)

Lenka Eisenhamerová

Legitimacy of 'Humanitarian Military Intervention'

MGSoG Dissertation Series, nr 26 (2011)

Sonila Tomini

Informal Payments for Health Care Services in Albania

MGSoG Dissertation Series, nr 25 (2011)

Jinjing Li

Dynamic Microsimulation in Public Policy Evaluation

MGSoG Dissertation Series, nr 24 (2011)

Aziz Atamanov

Rural Nonfarm Employment and International Migration as Alternatives to Agricultural Employment: The Case of Kyrgyztan

MGSoG Dissertation Series, nr 23 (2011) 
Frieda Vandeninden

Poverty Alleviation: Aid and Social Pensions

MGSoG Dissertation Series, nr 22 (2011)

Juliana Nyasha Tirivayi

The Welfare Effects of Integrating AIDS Treatment with Food Transfers: Evidence from Zambia

MGSoG Dissertation Series, nr 21 (2011)

Agnieska Ewa Sowa

Who's Left Behind? Social Dimensions of Health Transition and Utilization of Medical Care in Poland

MGSoG Dissertation Series, nr 20 (2011)

Emmanaouil Sfakianakis

The Role of Private Actors in the Provision of Public Goods with Applications to Infrastructure and Financial Stability

MGSoG Dissertation Series, nr 19 (2011)

Siu Hing Lo

White Collars Green Sleeves: An Interonganizational Compariso of Deteminants of Energie-Related Behaviors among Office Workers

MGSoG Dissertation Series, nr 18 (2011)

Treena Wu

Constraints to Human Capital Investment in Developing Countries: Using the Asian Financial Crisis in Indonesia as a Natural Experiment

MGSoG Dissertation Series, nr 17 (2011)

Henry Espinoza Peña

Impact Evaluation of a Job-Training Programme for Disadvantaged Youths: The Case of Projoven

MGSoG Dissertation Series, nr 16 (2011)

Florian Tomini

Between Family and Friends: Understanding the Interdependency of Private Transfers

MGSoG Dissertation Series, nr 15 (2010)

Michal Polakowski

The Institutional Transformation of Social Policy in East Central Europe:

Poland and Hungary in comparative and historical perspective

MGSoG Dissertation Series, nr 14 (2010) 
Maha Ahmed

Defining, Measuring and Adressing Vulnerability: The Case of Post Conflict Environments

MGSoG Dissertation Series, nr 13 (2010)

Pascal Beckers

Local Space and Economic Success: The role of spatial segregation of migrants in the Netherlands

MGSoG Dissertation Series, nr 12 (2010)

Victor Cebotari

Complicting Demands in Ethnically Diverse Societies: Ethnopolitical Contention and Identity Values in Europe

MGSoG Dissertation Series, nr 11 (2010)

Dennis Gyllensporre

Competing and Complementary Perspectives on the EU as a Crisis Management Actor: An Examination of the Common Security and Defence Policy through the Lenses of Idealism and Realism

MGSoG Dissertation Series, nr 10 (2010)

Judit Vall Castello

Business Cycle and Policy Effects on Labour Market Transitions of Older and Disabled Workers in Spain

MGSoG Dissertation Series, nr. 9 (2010)

Keetie Roelen

False Positives or Hidden Dimentions: the definition and measurement of child poverty

MGSoG Dissertation Series, nr. 8 (2010)

Denisa Maria Sologon

Earning Dynamics in Europe

MGSoG Dissertation Series, nr. 7 (2010)

Melissa Siegel

Money and Mobility: Migration and Remittances

MGSoG Dissertation Series, nr. 6 (2010)

Jessica S. Hagen-Zanker

Modest Expectations: Causes and effects of migration on migrant households in source countries

MGSoG Dissertation Series, nr. 5 (2010) 
Mirtha R. Muniz Castillo

Human Development and Autonomy in Project Aid: Experiences from four bilateral projects in Nigaragua and El Salvador

MGSoG Dissertation Series, nr. 4 (2009)

Christiane Arndt

Governance Indicators

MGSoG Dissertation Series, nr. 3 (2009)

Britta Augsburg

Microfinance - Greater Good or Lesser Evil?

MGSoG Dissertation Series, nr. 2 (2009)

Geranda Notten

Measuring and Managing Poverty Risks

MGSoG Dissertation Series, nr. 1 (2008) 